SZEGEDI TUDOMÁNYEGYETEM

TERMÉSZETTUDOMÁNYI ÉS INFORMATIKAI KAR

MIKROBIOLÓGIAI TANSZÉK

BIOLÓGIA DOKTORI ISKOLA

\title{
AZ ELSŐ EUKARIÓTA NIKOTINSAV LEBONTÁSI ÚTVONAL FELDERÍTÉSE ASPERGILLUS NIDULANS-BAN
}

DOKTORI ÉRTEKEZÉS

BOKOR ESZTER

TÉMAVEZETŐ:

DR. HAMARI ZSUZSANNA

EGYETEMI DOCENS

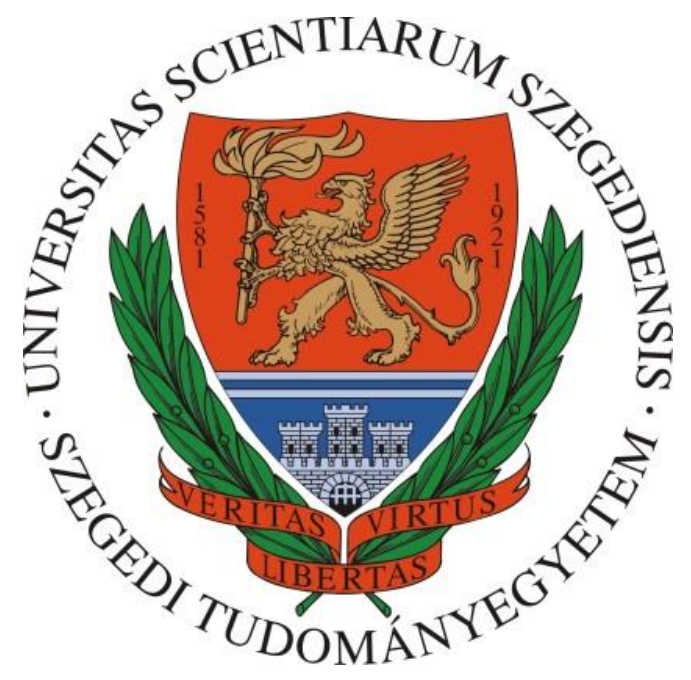

SZEGED

2019 


\section{Tartalom}

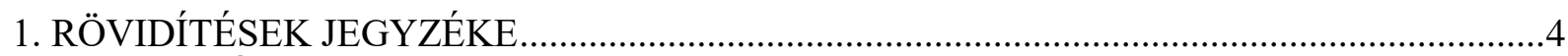

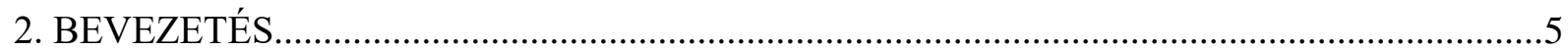

3. IRODALMI ÁTTEKINTÉS.......................................................................................

3.1. Az Aspergillus nemzetség jellemzése......................................................................... 6

3.2. A nikotinsav élettani szerepe ............................................................................... 7

3.3. A nikotinsav hasznosítása prokariótákban ………………………………………….... 8

3.4. Az első eukarióta nikotinsav degradációs klaszter (NDC1) felfedezése .............................. 11

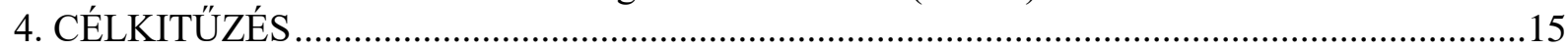

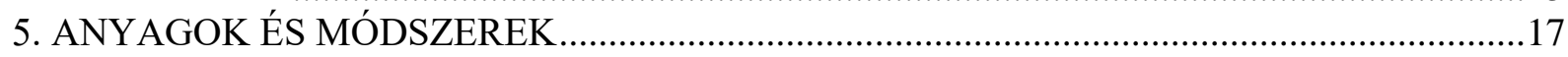

5.1. Felhasznált mikroorganizmusok ..................................................................................... 17

5.2. Tenyésztési körülmények ……………………………………………………………. 17

5.2.1. A. nidulans tenyésztésére felhasznált táptalajok ……………………………………. 17

5.2.2. Escherichia coli tenyésztéséhez felhasznált táptalajok................................................ 18

5.2.3. Az A. nidulans tenyésztési körülményei .................................................................. 18

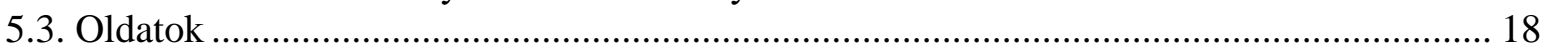

5.3.1. DNS izoláláshoz felhasznált oldatok ................................................................... 18

5.3.2. E. coli kompetens sejt gyártáshoz és transzformálásához felhasznált oldatok .............. 18

5.3.3. Aspergillus transzformáláshoz felhasznált oldatok..................................................... 19

5.3.4. Southern-blottoláshoz felhasznált oldatok ………………………………………....... 19

5.3.5. Southern-hibridizációhoz felhasznált oldatok …………………………………….... 19

5.3.6. Horizontális gél elektroforézishez használt oldatok ..................................................... 19

5.3.7. HPLC-MS mérésekhez használt oldatok ………………………………………..... 19

5.4. Kompetens E. coli sejtek készítése .......................................................................... 19

5.5. Kompetens $E$. coli sejtek transzformálása ...................................................................... 20

5.6. Aspergillus transzformálás ..................................................................................... 20

5.7. A. nidulans törzsek létrehozása keresztezéssel...……………………………………..... 21

5.8. Nukleinsav-manipulációhoz felhasznált módszerek...………………………………..... 22

5.8.1. Totál DNS kivonás A. nidulans-ból.................................................................... 22

5.8.2. RNS kivonás A. nidulans-ból, cDNS szintézis ........................................................... 22

5.8.3. Plazmid minipreparátumok készítése E. coli-ból .................................................... 23

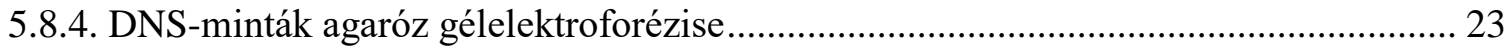

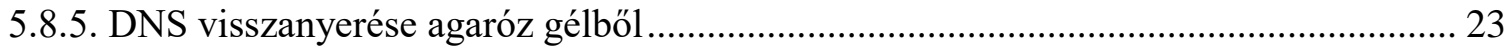

5.8.6. DNS emésztése restrikciós endonukleázokkal ........................................................ 23

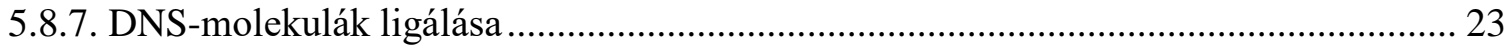

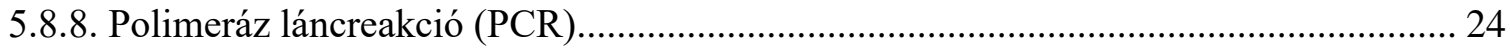

5.8.9. Kvantitatív valós idejú polimeráz láncreakció (RT-qPCR) .......................................... 24

5.8.10. Southern-hibridizációo...………………………………………………………..... 24

5.9. A $h x n V$ és $h x n W$ cDNS szekvenciák felsokszorozása ………………………………..... 24

5.10. A szubsztitúciós kazetták létrehozása a $h x n S, h x n S / h x n T, h x n V, h x n X, h x n W, h x n M$ és $h x n N$ gének deléciójához ................................................................................................ 25

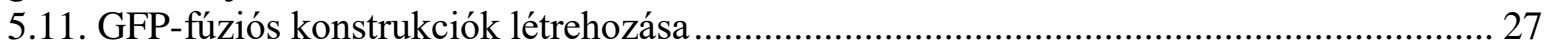

5.11.1. A $h x n V$-gfp-t (C-terminális GFP-fúziós fehérjét) kódoló konstrukció létrehozása .... 27

5.11.2. A gfp-hxnX-et (N-terminális GFP-fúziós fehérjét) kódoló konstrukció létrehozása .. 28

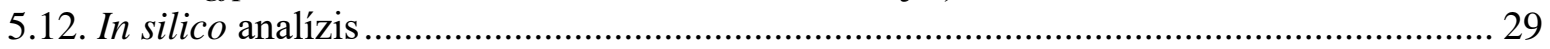

5.12.1. Ortológ keresés ……………………………………………………………........ 29

5.12.2. Lokalizációs szignál keresés ................................................................................... 29

5.12.3. Homológia keresés............................................................................................ 29

5.13. Mintaelökészítés a fluoreszcens mikroszkópos vizsgálatokhoz ………………………….... 30

5.14. Mintaelökészités és extrakció GC-MS és HPLC-MS analízishez...................................... 30

5.15. Mérési körülmények GC-MS analízis esetén ............................................................. 30

5.16. Mérési körülmények HPLC-MS analízis esetén.............................................................. 31 
6.1. Az NDC1 klasztergéneken kívül további, nikotinsav lebontásban szerepet játszó gének keresése.

6.1.1. In vivo megközelítés - hxn6 mutáns transzformálása $A$. nidulans génbankkal, a hxn6 mutáció azonosítása és az NDC2 génklaszter felfedezése.

6.1.2. In silico megközelítés -a $h x n$ gének egymáshoz viszonyított genomi elrendeződésének vizsgálata .

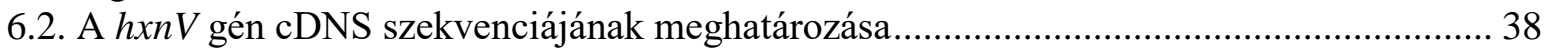

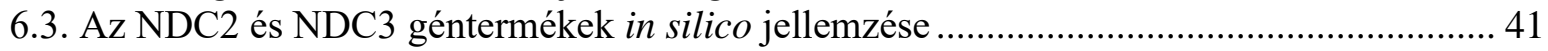

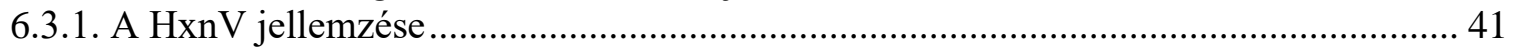

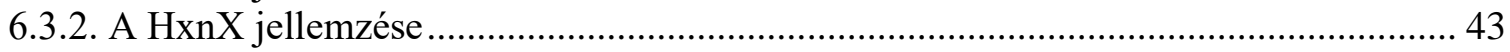

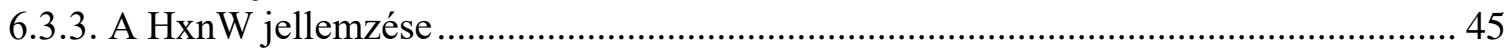

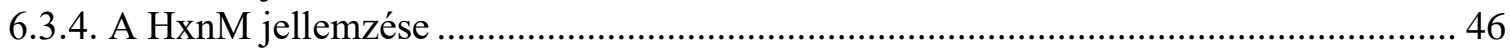

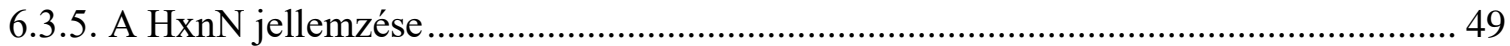

6.4. A $h x n S \Delta, h x n S \Delta / h x n T \Delta, h x n S \Delta / h x n Y \Delta, h x n T \Delta / h x n Y \Delta$ és $h x n S \Delta / h x n T \Delta / h x n Y \Delta$ deléciós

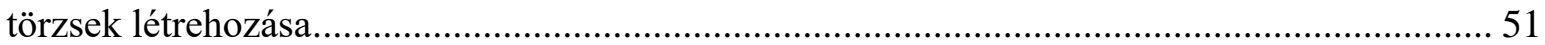

6.4.1. A hxnS deléciós törzs létrehozása $p_{a b a A^{+}}$szelekciós markerrel végzett

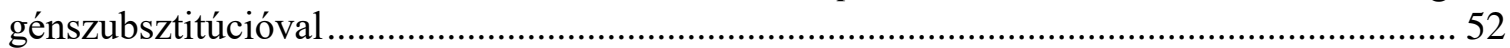

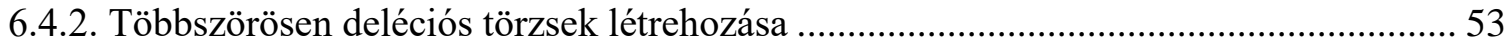

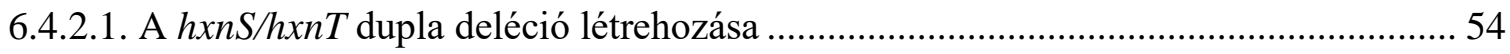

6.4.2.2. A $h x n S / h x n Y$ és $h x n T / h x n Y$ dupla deléciók létrehozása .............................................. 56

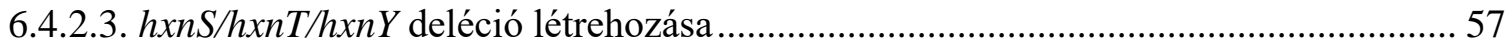

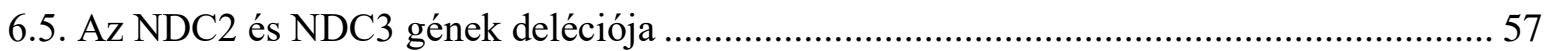

6.6. Az NDC1, NDC2 és NDC3 génekre deléciós törzsek NA hasznosítási képességének

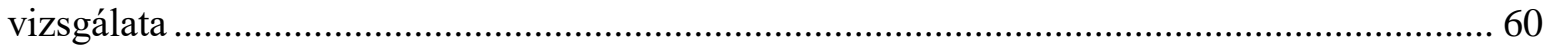

6.7. A deléciós törzsek konstitutív $h x n R\left(h x n R^{c}\right)$ háttérbe történő keresztezése NA származék hasznosítási tesztekhez és analitikai vizsgálatokhoz történő mintakészítés céljából ................. 63

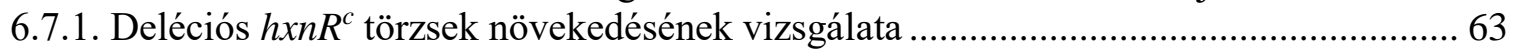

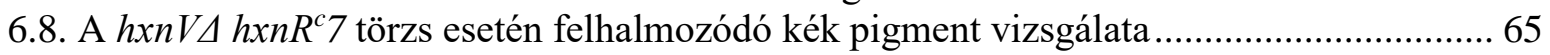

6.8.1. A kék pigment képződésének vizsgálata halmozottan deléciós mutánsokban ............. 67

6.9. Az útvonal intracelluláris színterének vizsgálata GFP-fúziós törzsek létrehozásával és

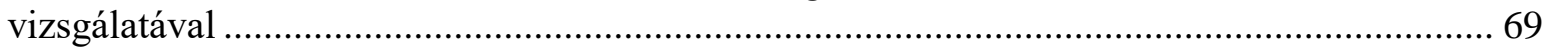

6.9.1. A $h x n V$-gfp fúziós konstrukciót kifejező törzs létrehozása....................................... 70

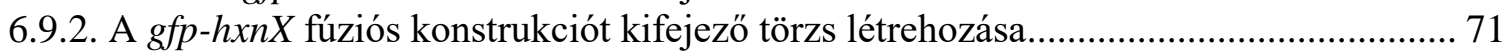

6.10. További deléciós törzsek létrehozása analitikai vizsgálatokhoz ....................................... 72

6.10.1. A hxnM $\Delta / h x n X \Delta$ dupla mutáns törzs létrehozása analitikai vizsgálati anyagok

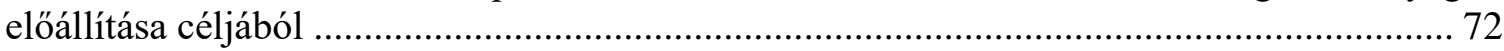

6.10.2. A hxnM $\Delta / h x n V \Delta$ dupla mutáns törzs létrehozása analitikai vizsgálati anyagok

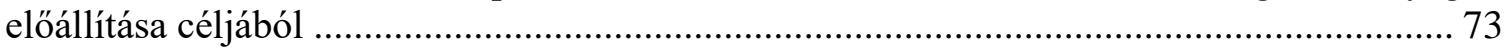

6.10.3. A hxnM $\Delta / h x n W \Delta$ dupla mutáns törzs létrehozása analitikai vizsgálati anyagok

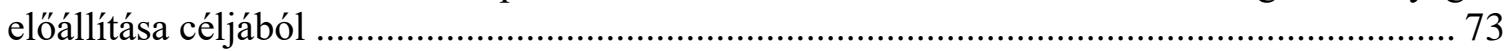

6.11. A deléciós mutánsok GC-MS és HPLC-MS analízissel történő vizsgálata ...................... 75

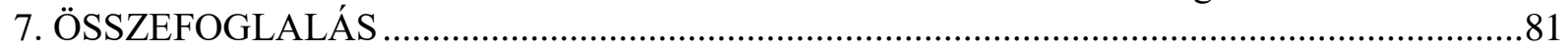

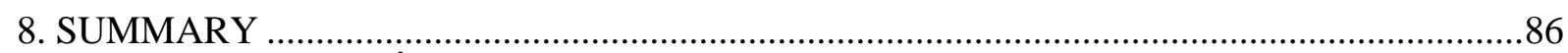

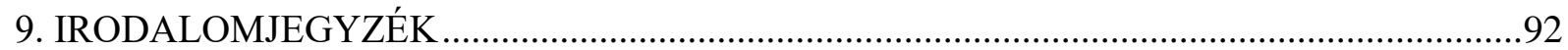

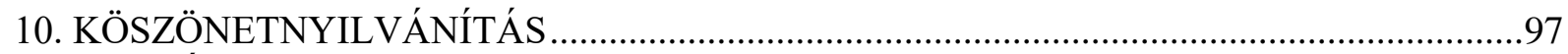

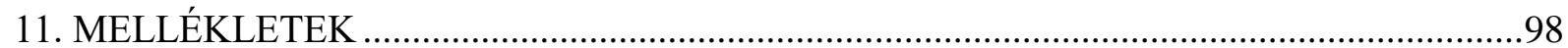




\section{RÖVIDÍTÉSEK JEGYZÉKE}

2,5-DP: 2,5-dihidroxipiridin

6-NA: 6-hidroxi-nikotinsav (--hydroxynicotinic acid)

Allp: allopurinol

AS: aminosav

BLAST: $\underline{B}$ asic Local $\underline{\text { Alignment }} \underline{\text { Search }} \underline{\text { Tool }}$

bp: bázis pár

cDNS: komplementer DNS (complementary DNA)

CM: komplett táptalaj (complete medium)

downst (down): lentebbi (

frw: előre irányuló (ㅁorward)

GC-MS: gázkromatográfiával kapcsolt tömegspektrometria (Gas Chromatography-Mass Spectrometry)

GFP: zöld fluoreszcens fehérje (green fluorescent protein)

HPLC-MS: folyadékkromatográfiával kapcsolt tömegspektrometria (ㅂigh Performance Liquid Chromatography- $\underline{\text { Mass }} \underline{\text { Spectrometry) }}$

Hx: hipoxantin

kb: kilobázis

MM: minimál táptalaj (

NA: nikotinsav (nicotinic acid)

NAA: nikotinamid (nicotinic acid amide)

NDC: nikotinsav degradációs klaszter (ñicotinic acid degradation cluster)

nt: nukleotid

PCR: polimeráz láncreakció (polymerase chain reaction)

PHI: purin hidroxiláz I

PHII: purin hidroxiláz II

RT-qPCR: kvantitatív valós idejü polimeráz láncreakció (Quantitative real-time polymerase chain reaction)

rev: visszafelé irányuló (reverse)

RFP: vörös fluoreszcens fehérje (red fluorescent protein)

SDR: rövid láncú dehidrogenáz/reduktáz (hort chain dehydrogenase/reductase)

upst (up): fentebbi (upstream) 


\section{BEVEZETÉS}

Habár számos mikroorganizmus képes a nikotinsav (NA) nitrogénforrásként történő hasznosítására, eddig mindössze prokariótákban vizsgálták a lebontási útvonalakat. Eukarióták esetében teljesen tisztázatlan a lebontás folyamata. Csoportunk munkáját megelőzően csak az útvonal feltételezett regulátora (HxnR), valamint az útvonal első lépése volt ismert Aspergillus nidulans modellorganizmusban, mely során a Purin hidroxiláz II (PHII) enzim a NA-at 6hidroxi-nikotinsavvá (6-NA) alakítja át. Kutatócsoportunkban ezen ismeretekből kiindulva kezdtük el a NA lebontási útvonal tanulmányozását. Feltártunk egy NA katabolizmusban szerepet játszó géneket magába foglaló génklasztert, amelybe a transzkripciós faktort és a PHII enzimet kódoló $h x n R$ és $h x n S$ gén, valamint további négy gén, a $h x n Y$, $h x n T$, $h x n P$ és $h x n Z$ tartozik (Ámon és mtsai., 2017). A klaszter génjei koregulációt mutatnak, amely a NA és annak downstream metabolitjai, 6-NA és 2,5-dihidroxi-piridin (2,5-DP) által aktiválódnak és függenek a HxnR transzkripciós faktortól, valamint az útvonal pozitív koregulátorától, az AreA-tól (Ámon és mtsai., 2017). A klaszter $h x n Y, h x n T, h x n P$ és $h x n Z$ génjeire nézve deléciós törzsek kombinált deléciós párosításban is úgynevezett „leaky” fenotípust mutatnak, amely egyrészt előre jelzi a NA alternatív utakon történő lebontásának lehetőségét, másrészt pedig utal arra, hogy további, eddig még nem azonosított gének is szerepet játszanak a lebontásban.

Munkánk során célunk volt a NA lebontásban szerepet játszó további gének felfedezése és azok funkciójának elemzése deléciós mutánsok előállításával, vizsgálatával, valamint analitikai vizsgálatokkal. Jelen doktori értekezésben a NA katabolikus útvonalban szerepet játszó, két klaszterbe rendeződő további öt gén felderítése és vizsgálata kerül bemutatásra deléciós mutánsok létrehozásán és NA hasznosítási képességének vizsgálatán keresztül. Emellett bemutatjuk a deléciós mutánsokkal végzett in silico, GC-MS és HPLC-MS vizsgálatok eredményeit. A vizsgálatok során kapott eredményeink alapján a NA lebontása eukariótákban a prokariótáktól eltérő módon, alternatív utakon történik. Az útvonal teljes feltárása során azonosított enzimek és enzimreakciók heterociklus módosító aktivitásuknál fogva, valószínüleg nagy érdeklődésre fognak szert tenni a gyógyszeriparban (hatóanyag prekurzorok), valamint az agrokémia iparban (növényvédő szer prekurzorok) a heterociklus alapú bioaktív hatóanyagok olcsó, környezetkímélő előállításához. 


\section{IRODALMI ÁTTEKINTÉS}

\subsection{Az Aspergillus nemzetség jellemzése}

Az A. nidulans fonalasgomba az Ascomycota törzs Eurotiomycetes osztályának Eurotiales rendjébe tartozó Trichocomaceae család Aspergillus nemzetségének tagja. A családba tartozó megközelítőleg 250 faj (Sugui és mtsai., 2014) közül a legtöbb csak aszexuális szaporodásra képes, szexuális ciklussal mindössze a nemzetség néhány faja rendelkezik, köztük az A. nidulans. Az A. nidulans termőteste egy kerek, zárt struktúra (kleisztotécium), amelyben a 8 aszkospórát tartalmazó aszkuszok találhatóak. A kleisztotéciumok falát differenciálódott hifák alkotják és a termőtestet kívülről vastag falú Hülle sejtek borítják be (Pontecorvo és mtsai., 1953).

Az Aspergillus fajok az ember környezetében előforduló egyik legelterjedtebb gombacsoport. Változatos élőhelyeken találkozhatunk velük, mint például a talajban, takarmánynövényeken, különböző élelmiszereken, valamint a bomló szerves anyagokban is (Fogarty, 1994). Az Aspergillus fajok számos előnyös tulajdonsággal rendelkeznek. Nagy mennyiségben termelnek az ipar számára komoly jelentőséggel bíró szerves savakat (pl. citromsav, glükonsav és itakonsav) és enzimeket (pl. cellulázok, amilázok, proteázok, lipázok és pektinázok), emellett egyes másodlagos metabolitok (pl. lovasztatin, különbözö peptid antibiotikumok, és béta-laktám penicillin) gyógyászati hatóanyagokként váltak életünk nélkülözhetetlen részévé (Ward és mtsai., 2005). Ugyanakkor bizonyos másodlagos metabolitjaik egészségkárosító hatásukról hírhedtek. Az aflatoxin, ochratoxin, vagy az aflatoxin prekurzora, a sterigmatocisztin (Schroeder \& Kelton, 1975, Bennett \& Papa, 1988) állati vagy emberi táplálékba jutása komoly gazdasági és egészségügyi problémát jelent.

$\mathrm{Az}$ A. nidulans fonalasgomba a molekuláris biológiában gyakran alkalmazott modellszervezet, amely köszönhető a táptalajon és folyadékkultúrában történő gyors növekedésének; széles körben tanulmányozott szexuális-, vegetatív- és paraszexuális életciklusának; metabolikus sokoldalúságának; a hozzáférhető sokféle auxotróf mutánsnak, amelyek nagyban megkönnyítik a genetikai, illetve molekuláris biológiai vizsgálatokat; önkeresztezhetőségének; valamint haploid genomjának. Számos biológiai folyamatot vizsgáltak rajta, mellyel hozzájárult a metabolikus szabályozás, fejlődés, sejtciklusszabályozás, mitokondriális intron terjedés, a kromatinszerkezet, citoszkeleton-funkció, a humán genetikai betegségek és még számos más, sejtműködésben érintett folyamat megértéséhez (Pontecorvo és mtsai., 1953, Goldman \& Kafer, 2004, Osmani \& Mirabito, 2004). Mivel az A. nidulans teljes genomszekvenciája 2005 óta elérhető 
(www.broadinstitute.org/scientific-community/science/projects/fungal-genomeinitiative/aspergillus-genome-projects), képes a NA-at egyedüli nitrogénforrásként hasznosítani, és a '60-as évekből fennmaradt néhány elérhető NA nem-hasznosító mutáns, az A. nidulans megfelelő modellszervezetnek bizonyult az eukarióta NA katabolikus útvonal felderítéséhez.

\subsection{A nikotinsav élettani szerepe}

A NA (niacin, B3-vitamin) egy N-heterociklusos aromás vegyület, vízben oldódó vitamin, amely a nikotinamid-adenin-dinukleotid (NAD) és a nikotinamid-adenin-dinukleotidfoszfát (NADP) koenzimek prekurzoraként számos metabolikus folyamatban játszik szerepet (pl. glikolízis, pentóz-foszfát ciklus) (Ikeda és mtsai., 1965). A NA-at a szervezet külső és belső forrásból is képes pótolni. Külső forrásból a táplálkozás útján, belső forrásból pedig a triptofán niacinná történő átalakítása révén, illetve a vastagbél normál mikroflórája által megtermelt niacin felvétele által (Said, 2011). A NA képes a plazmában növelni a high-density lipoprotein (HDL)-koleszterin szintjét, illetve csökkenteni a low-density lipoprotein (LDL)-koleszterin-, a trigliceridek és a lipoprotein koncentrációját, ezért potenciálisan fontos gyógyszerészeti hatóanyagnak tekinthető (MacKay és mtsai., 2012). A sztatinok (lipoprotein-koleszterin szint csökkentésére alkalmazott terápiás szerek) ismeretesek arról, hogy képesek 25-40\%-kal csökkenteni a kardiovaszkuláris elégtelenségek kialakulásának esélyét és az emiatt bekövetkező elhalálozás lehetőségét. Abban az esetben azonban, amikor a sztatinokat NA-val kombinálták, 60-90\%-os csökkenést tapasztaltak a szívelégtelenség és az emiatt bekövetkezett elhalálozások számában (Al-Mohaissen és mtsai., 2010). Ezeknek a statisztikai adatoknak a magyarázata az, hogy habár a sztatinok csökkentik az úgynevezett „,rossz” koleszterinek (LDLkoleszterinek) szintjét, ha NA-val kombinálják, amely az úgynevezett ,jó” koleszterinek (HDLkoleszterinek) mennyiségét növeli, akkor a sztatinok hatékonyabban védenek a kardiovaszkuláris elégtelenségekkel szemben.

A NA hiánya a pellagra nevü betegséghez vezethet, mely a nyálkahártyák gyulladásával, bőrelváltozásokkal, hasmenéssel és idegrendszeri rendellenességekkel jár. A NA hiánya, vagy nem optimális szintje leginkább alkoholbetegeknél, valamint Hartnup-kórban szenvedő egyéneknél fordul elő. Az utóbbi esetében a triptofán aminosav (AS) (az endogén NA szintézisének prekurzora) transzportere szenved mutációt (Said, 2011).

A NA a prokarióták számára szén- és nitrogénforrásként is hasznosítható, azonban jelenlegi ismereteink alapján a gombák számára csak nitrogénforrásként tud hasznosulni. A 
prokarióta NA lebontását szolgáló biokémiai útvonalak tanulmányozásakor azonosított enzimek és metabolikus köztitermékek komoly ipari jelentőséggel bírnak a farmakológiában és az agrokémiában. Széles szubsztrát-specificitása miatt a nikotinsav-dehidrogenázt többek között Mycobacterium fajok által okozott tuberkulózis elleni szerek gyártása során alkalmazzák (Yoshida \& Nagasawa, 2000). A 6-hidroxi-nikotinsav-3-monooxigenáz enzim müködése során a 6-NA-ból 2,5-DP képződik, amely az 5-aminolevulinsav képződésének köztesterméke. Az 5aminolevulinsavat növekedésszabályozó növényi hormonként, rovarölő szerként, valamint börés szájrák fotodinamikus diagnózisa és terápiája során alkalmazzák (Nakano és mtsai., 1999), a 6-NA-at pedig elsősorban újgenerációs rovarölö szerek építőelemeként alkalmazzák (Schmid és mtsai., 2001). A mikrobiális enzimek továbbá eszközt jelentenek a komoly környezeti problémákat okozó toxikus vegyületek (pl. nikotin és hidroxipiridin) lebontásához is (Fetzner, 1998, Yoshida \& Nagasawa, 2000, Wang és mtsai., 2004).

\subsection{A nikotinsav hasznosítása prokariótákban}

A természetben a NA endogén módon szintetizálódhat a sejteken belül (kivételt képezhetnek egyes parazita fajok), de transzporterek segítségével be is juthat az extracelluláris környezetből (Pelczar \& Porter, 1940, Tinschert és mtsai., 1997). Ahogy a 3.2. alfejezetben említettük, sok mikroorganizmus rendelkezik a NA nitrogén- és/vagy szénforrásként történő hasznosításának képességével. Prokariótákban a NA hasznosítást kiterjedten tanulmányozták és ennek alapján háromféle katabolikus útvonalat ismertek meg (1. ábra) (Behrman \& Stanier, 1957, Ensign \& Rittenberg, 1964, Alhapel és mtsai., 2006, Jimenez és mtsai., 2008). 

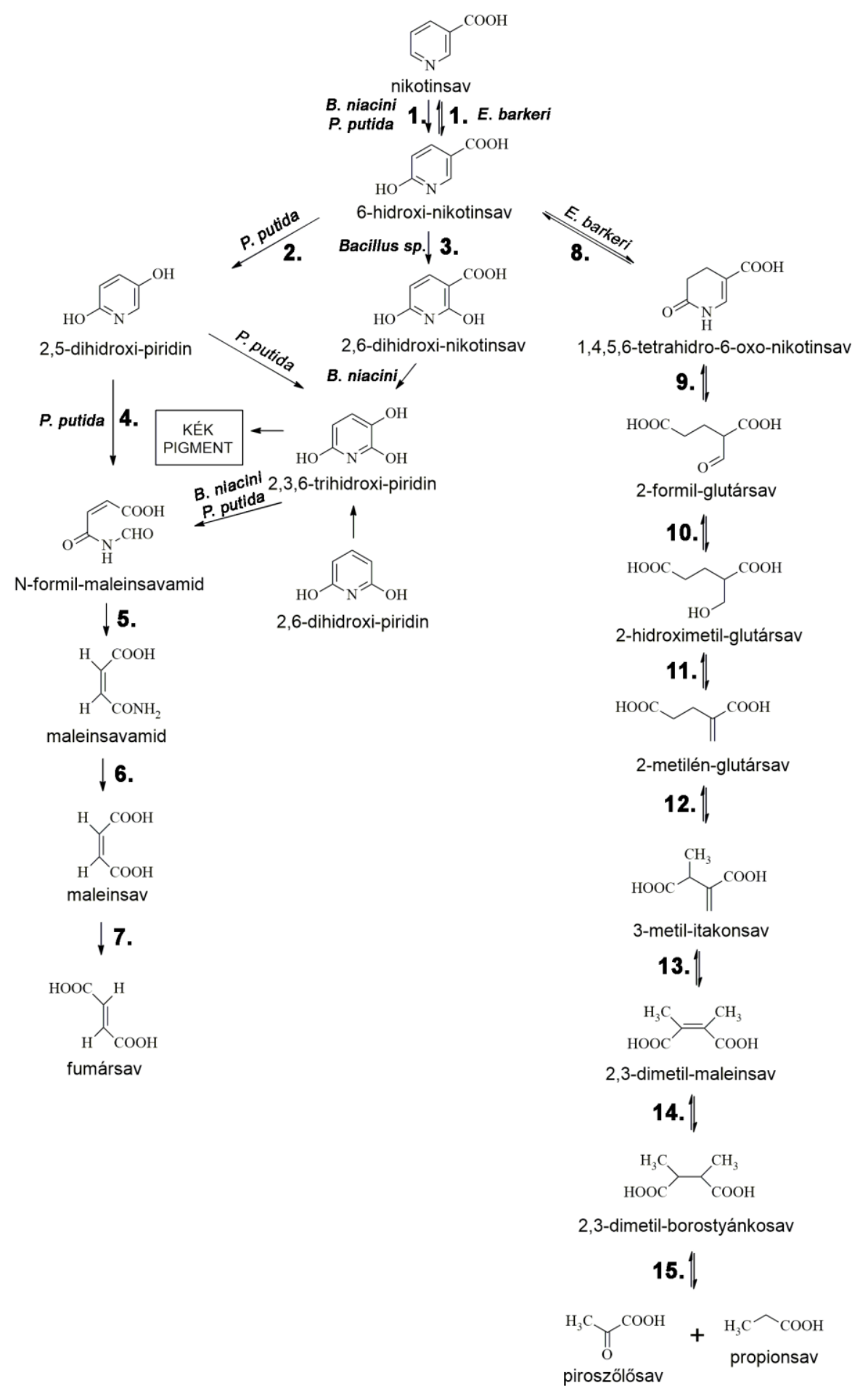

\section{1. ábra: A NA lebontásának folyamata Pseudomonas putida, Bacillus niacini és Eubacterium barkeri} esetében.

Az ábrán a $P$. putida (Jimenez és mtsai., 2008), B. niacini (Ensign \& Rittenberg, 1964) és E. barkeri (Alhapel és mtsai., 2006) baktériumok NA lebontási útvonalai láthatóak. A számok az adott lépést katalizáló enzimeket jelölik: 1. nikotinsav-hidroxiláz (nikotinsav-dehidrogenáz), 2. 6-hidroxi-nikotinsav-monooxigenáz, 3. 6-hidroxinikotinsav-dehidrogenáz, 4. piridin-2,5-diol dioxigenáz, 5. N-formil maleinsavamid deformiláz, 6.

maleinsavamid amidohidroláz, 7. maleinsav izomeráz, 8. 6-hidroxi-nikotinsav-reduktáz, 9. enamidáz, 10. 3hidroxi-izobutirát/foszfoglukonát-dehidrogenáz, 11. szerin-dehidratáz-szerü enzim, 12. B12-koenzim-dependens 2-metilénglutarát-mutáz, 13. 3-metilitakonát-izomeráz, 14. (2R,3S)-dimetilmalát-dehidratáz, 15. (2R,3S)dimetilmalát-liáz. 
A NA lebontás legelső lépése megegyezik mindhárom típusú útvonalban. Ez a lépés a NA átalakítása 6-NA-vá egy nikotinsav-hidroxiláz (nikotinsav-dehidrogenáz) által (1. ábra). Ezt követően a lebontás a Pseudomonas fajok esetén (például $P$. putida, $P$. fluorescens) a 6-NA 2,5-DP-né történő átalakításával folytatódik, amelyben egy 6-hidroxi-nikotinsavmonooxigenáz játszik szerepet (1. ábra). A 2,5-DP egy $\mathrm{N}$-formil maleinsavamid, majd maleinsavamid intermedieren keresztül maleinsavvá alakul piridin-2,5-diol dioxigenáz, Nformil maleinsavamid deformiláz és maleinsavamid amidohidroláz segítségével (Jimenez és mtsai., 2008) (1. ábra). Az utóbbi amidohidroláz aktivitás során a maleinsavamid köztitermék amid csoportja lecserélődik egy hidroxil csoportra. Az amid csoport végső soron ammóniummá alakulva nitrogénforrásként hasznosul. A maleinsavamid amidcsoportjának eltávolításával létrejött maleinsav fumársavvá alakul (egy maleinsav izomeráz révén) és betáplálódik a SzentGyörgyi-Krebs-ciklusba és végső soron szén-forrásként hasznosul (Jimenez és mtsai., 2008). A Bacillus niacini baktériumban a 6-NA-ból egy 2,6-dihidroxi-nikotinsav (2,6-DNA) intermedieren keresztül (6-hidroxi-nikotinsav-dehidrogenáz segítségével) jön létre a maleinsavamid, a lebontás további lépései pedig megegyeznek a Pseudomonas fajok esetében leírt útvonal lépéseivel (Ensign \& Rittenberg, 1964) (1. ábra). Mind a Pseudomonas, mind a Bacillus által képviselt útvonal esetén feltételezik egy 2,3,6-trihidroxi piridin származék létrejöttét a piridingyürü felnyílása előtt (az N-formil maleinsavamid keletkezése előtt), amelyböl nem enzimatikus úton egy kék színű pigment, egy azakinon származék jön létre (Ensign \& Rittenberg, 1963) (1. ábra).

A NA-ból keletkezett 6-NA lebontásának harmadik lehetséges módját a Clostridiales rend bizonyos tagjai, például az Eubacterium barkeri vizsgálata során írták le (1. ábra). Az E. barkeri a $P$. putida illetve a $B$. niacini degradációjától teljesen eltérö, anaerob lebontási útvonallal rendelkezik. Az E. barkeriben egy kilenc génből álló klaszter egyedi fermentációs útvonalat biztosít, amelyben a NA-ból végül piroszőlősav és propionsav képződik. A NA 6NA-vá történő oxidációját egy négy alegységes (nem szelenocisztein) szelén tartalmú nikotinsav-dehidrogenáz enzim katalizálja. A 6-NA-at a 6-hidroxi-nikotinsav-reduktáz redukálja 1,4,5,6-tetrahidro-6-oxo-nikotinsavvá, amelyet az enamidáz enzim ammóniummá és (S)-2-formil-glutaráttá hidrolizál (1. ábra). Ez utóbbit egy 3-hidroxi-izobutirát/foszfoglukonátdehidrogenáz enzim tovább redukálja (S)-2-hidroximetil-glutaráttá, majd feltételezhetően egy szerin-dehidratáz-szerü enzim 2-metilénglutarátot képez, amely a B12-koenzim-dependens 2metilénglutarát-mutáz, a 3-metilitakonát-izomeráz, a (2R,3S)-dimetilmalát-dehidratáz és a (2R,3S)-dimetilmalát-liáz működésén keresztül piroszőlősavvá alakul (1. ábra). In silico elemzéssel kilenc Proteobacteria esetében azonosították az E. barkeri NA lebontásának első 
három enzimét kódoló gének homológjait, de a teljes NA lebontási útvonalat nem tárták fel, bár az útvonal teljes megismerése váratlan újdonságokat tartogathat (Alhapel és mtsai., 2006). A prokarióta lebontási útvonal első enzimeinek in silico összehasonlítása azt mutatta, hogy az $E$. barkeri-ben, a Pseudomonas aeruginosa-ban és az Azorhizobium caulinodans-ban előforduló nikotinsav-hidroxilázok nem állnak evolúciós kapcsolatban egymással, ami azt jelenti, hogy a nikotinsav-hidroxilázok egymástól függetlenül, számos alkalommal jelentek meg az evolúció során (Ámon és mtsai., 2017).

\subsection{Kék pigment felhalmozódás a Pseudomonas és Bacillus útvonalak esetén}

Pseudomonas és Bacillus fajok, valamint Arthrobacter crystallopoietes esetén NA-at, mint egyedüli szén- és nitrogénforrást tartalmazó tápközegben történő tenyésztés során megfigyelték, hogy kék színü pigment halmozódik fel a telepekben, amely a tápközegbe is kibocsájtódik (Ensign \& Rittenberg, 1963, Ensign \& Rittenberg, 1964)Jimenez személyes közlés). A kék színü pigmentet kémiai jellemzése során egy monopiridol oxidációs termékeként írták le, amely neutrális, vagy enyhén lúgos oldatban anionként intenzív kék színnel rendelkezik, savas közegben pedig metál sóként precipitálódik. Az 1880-as és 1960-as évek között számos dipiridol és származékainak kémiai jellemzését publikálták, melyek közül egyesek esetén leírták, hogy kék színü pigmentet hoz létre, valószínüsíthetően egy tripiridol intermedier képződésen keresztül (1. ábra). A 2,3,4-trihidroxi piridin, 2,4,6-trihidroxi pikolin és a 4-metil-2,3,6 tripiridol vegyületek mindegyikéből lehetséges kék színű pigmentet létrehozni (Ensign \& Rittenberg, 1963). Az Ar. crystallopoietes esetén úgy gondolták, hogy a kék színủ pigmentet a Boyer és Kruger (Boyer \& Kruger, 1957) által vizsgált azakinon néven emlegetett 6-hidroxi-2,3 piridon és 2-hidroxi-3,6 piridon tautomerek alkotják. Ezek az azakinonok mély lilás-barna, vagy vöröses-barna színűek, közönséges oldószerekben nem, vagy nehezen, alkalikus közegben pedig könnyen oldódnak, miközben intenzív kék színűvé válnak. A kék szín oxigenált közegben elhalványul az anyag bomlásával.

\subsection{Az első eukarióta nikotinsav degradációs klaszter (NDC1) felfedezése}

Kutatásaink eredményeképpen az A. nidulans VI. kromoszómáján felfedeztünk egy génklasztert, amely tartalmazza a NA lebontási útvonal génjeinek közös transzkripciós faktorát $(h x n R)$, valamint a $h x n S, h x n P, h x n Z, h x n Y$ és $h x n T$ géneket (Ámon és mtsai., 2017). A kutatásunk során alkalmazott vizsgálati rendszerek megértését szolgálja, ha történeti sorrendben ismertetjük az NDC1 klaszter felfedezését. 
Régóta ismert a purin hasznosítási útvonalban részt vevő purin hidroxiláz I enzim (PHI, a hxA gén terméke) (Lewis és mtsai., 1978, Mehra \& Coughlan, 1989, Glatigny \& Scazzocchio, 1995), mely a hipoxantint (Hx) xantinná, a xantint pedig húgysavvá képes hidroxilálni. A PHI enzim funkcióvesztéses mutánsainak létrehozása és elemzése során kiderült, hogy létezik egy másik enzim (purin hidroxiláz II, PHII), amely azon kívül, hogy molekulamérete és izoelektromos pontja igen közel áll a PHI-éhez és szintén molibdenopterin kofaktort igényel aktivitásához, képes a $\mathrm{Hx} \rightarrow$ xantin átalakításra, azonban nem képes a xantin $\rightarrow$ húgysav átalakítás elvégzésére (Scazzocchio, 1973, Lewis és mtsai., 1978, Coughlan és mtsai., 1984). A xantin $\rightarrow$ húgysav átalakítást a mutánsokban PHI hiányában egy alternatív, $\alpha$-ketoglutarátfüggő xantin-dehidrogenáz (XanA) végzi (Sealy-Lewis és mtsai., 1978). A PHII enzim biokémiai vizsgálata során kiderítették, hogy nem csak a $\mathrm{Hx} \rightarrow$ xantin átalakítást, hanem a $\mathrm{NA} \rightarrow 6-\mathrm{NA}$ konverziót is képes elvégezni. Az enzim regulációjára vonatkozóan megállapították, hogy a PHI-el ellentétben a PHII aktivitását nem befolyásolja sem a húgysav, sem pedig a purin hasznosítási útvonal transzkripciós faktora (UaY), azonban a vad típusú törzsben Hx szubsztráton csak akkor detektálható PHII aktivitás, ha inducer mennyiségben (1 mM) NA-at, vagy 6-NA-at adnak a tápoldathoz (Scazzocchio, 1973). Ezek alapján a PHII-t a nikotinsav hasznosítási útvonal egyik enzimének tekintették és nem a purin lebontási útvonal részének. A PHII funkcióvesztéses mutánsokat két kategóriába lehetett besorolni. Az egyikbe azok a mutánsok tartoztak, amelyek Hx nitrogénforrás mellett allopurinolt (Allp, a PHI enzim gátlószere) tartalmazó, valamint NA nitrogénforrást tartalmazó táptalajon nem voltak képesek növekedni, de nőttek 6-NA nitrogénforrást tartalmazó táptalajon. Ezek a mutánsok a PHII-t kódoló gén funkcióvesztéses mutánsai (PHII-41, PHII-35). A második kategóriába azok a mutánsok tartoztak, amelyek a Hx nitrogénforrás mellett Allp-t tartalmazó, és a NA nitrogénforrást tartalmazó táptalajon kívül még a 6-NA nitrogénforrást tartalmazó táptalajon sem voltak képesek nőni. Ezekről azt gondolták, hogy vélhetőleg a PHII-t kódoló gén regulátorát érintő mutánsok $(h \times n R 2, h \times n R 3)$. Konstitutív mutánsokat is felfedeztek, amelyek neutrális nitrogénforráson indukció nélkül is aktív fehérjét termeltek. Ezeket aplA ${ }^{c}$ mutánsoknak nevezték (Scazzocchio és mtsai., 1973). A NA-at nem hasznosító mutánsok klasszikus genetikai vizsgálatával kimutatták, hogy nagyon erős kapcsoltság van a PHII-t kódoló gén és a $h x n R$ regulátor gén, valamint a konstitutivitást okozó aplA gén között. A $h x n R$ és $h x n S$ allélok mutánsain kívül számos más, NA és 6-NA nem-hasznosító mutánst is izoláltak, melyek a genetikai keresztezésekkel végzett analízisek eredményeként a $h x n R$ és $h x n S$ alléloktól távolabb térképeződtek (Joan Kelly és Claudio Scazzocchio személyes közlés). A 
létrehozott mutánsokon (a ’60-as években) végzett genetikai munka nem került közlésre az azt követő idő során és egy kivételével (hxnб) a törzsek is elvesztek. Ezen több évtizedes eredmények alapján a 2000-es évek elején kezdte el csoportunk felderíteni a NA degradációjának genetikai hátterét. Az útvonal feltárásának kiindulási pontja egy olyan gén azonosítása volt az A. nidulans genomban, amely homológ a PHI-et kódoló $h x A$ génnel. Ilyen gén a VI. kromoszómán található. A VI. kromoszóma génkönyvtárának transzformálása a PHII41 és hxnR2 mutánsokba egy olyan komplementáló kozmid izolálásához vezetett, mely mindkét törzs mutációját komplementálta. A kozmid szubklónozását és szekvenálását követően a PHII enzim génjeként az AN9178 gént azonosítottuk, a HxnR transzkripciós faktor génjeként pedig az AN11197 gént. Ezeket a géneket a korábban publikált genetikai és biokémiai vizsgálatok alapján $h x n S$-nek és $h x n R$-nek neveztük el. A prokariótákban megfigyelhető klaszterbe rendeződés a funkcionálisan összefüggő gének esetén, valamint a $h x n S$ és $h x n R$ gének között korábban felfedezett erős kapcsoltság arra ösztönzött minket, hogy megvizsgáljuk a hxnS és $h x n R$ génekkel szomszédos gének kifejeződését vad típusú törzsben indukció nélkül és 6-NA indukció mellett, valamint funkcióvesztéses $h x n R 2$ és funkciónyeréses $a p l A^{c} 7$ mutánsokban. A vizsgálat eredményeként egy 6 génből álló klasztert ( $h x n R$, hxnS, hxnP, hxnZ, hxnY és hxnT) azonosítottunk, amelyet nikotinsav degradációs klaszternek (NDC) neveztünk el. A hxnS gén által kódolt PHII enzim (HxnS) (Ámon és mtsai., 2017) végzi a katabolikus útvonal első lépését, azaz 6' hidroxilálja a NA-at. A $h x n R$ gén terméke egy Cys2His2 Zinc finger transzkripciós faktor, amely a klasztergének kifejeződéséhez elengedhetetlenül szükséges (Ámon és mtsai., 2017). A hxnT és a $h x n Y$ géntermékek (FMN oxidoreduktáz és egy $\alpha$-ketoglutarát függő

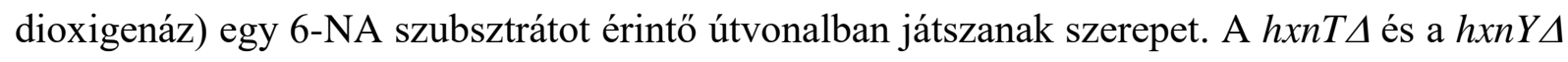
mutánsok NA hasznosítási profilja ellentmondásosnak bizonyult (NA nitrogénforráson képesek nőni, de 6-NA nitrogénforráson csökkent növekedést mutatnak), amely alapján azt feltételezzük, hogy egy alternatív útvonal müködik a NA katabolikus folyamatban. A hxnP gén terméke egy transzporter, amely a 6-NA és valószínüleg a NA kis affinitású transzportere (Ámon, 2018). A hxnZ géntermék is transzporter molekula, azonban a gén deléciója nem mutatott semmilyen növekedésbeli változást NA-at, 6-NA-at, vagy 2,5-DP-t tartalmazó táptalajon, így ennek a funkciója még tisztázásra vár (Ámon, 2018).

A prokarióta $P$. putida NA lebontási útvonalának egyik köztesterméke a 2,5-DP (Jimenez és mtsai., 2008). Az NDC1 klaszter elemzése során megvizsgáltuk, hogy az A. nidulans katabolizmusában szerepel-e a 2,5-DP. A vad típusú törzs képes volt növekedni 2,5DP nitrogénforrást tartalmazó táptalajon, a HxnR transzkripciós faktorra nézve deléciós mutáns azonban nem (2. ábra) (Ámon és mtsai., 2017), tehát a 2,5-DP az A. nidulans lebontási 
útvonalában is szereplő köztestermék. Ez az eredmény rávilágít arra, hogy az NDC1 klasztergéneken kívül más, szintén a HxnR transzkripciós faktor szabályozása alatt álló gének még részt vesznek a lebontási folyamatban. Jelen értekezés témája az útvonal feltételezett további génjeinek azonosítása és jellemzése. Mivel az 1960-as és '70-es évek során mutagenezissel létrehozott NA-at nem hasznosító mutáns törzsek közül egy törzs ( $h x n 6$ mutáns) mindmáig fennmaradt, amelyben a funkcióvesztésért felelős gén a genetikai keresztezések alapján a $h x n R$ és $h x n S$ lókuszoktól elkülönülten, de azok közelébe (kb. 40 kb távolságra) térképeződött (Joan Kelly személyes közlés), felbecsülhetetlen lehetőséget nyújtott számunkra, hogy megkezdjük az útvonalba részt vevő további gének azonosítását.

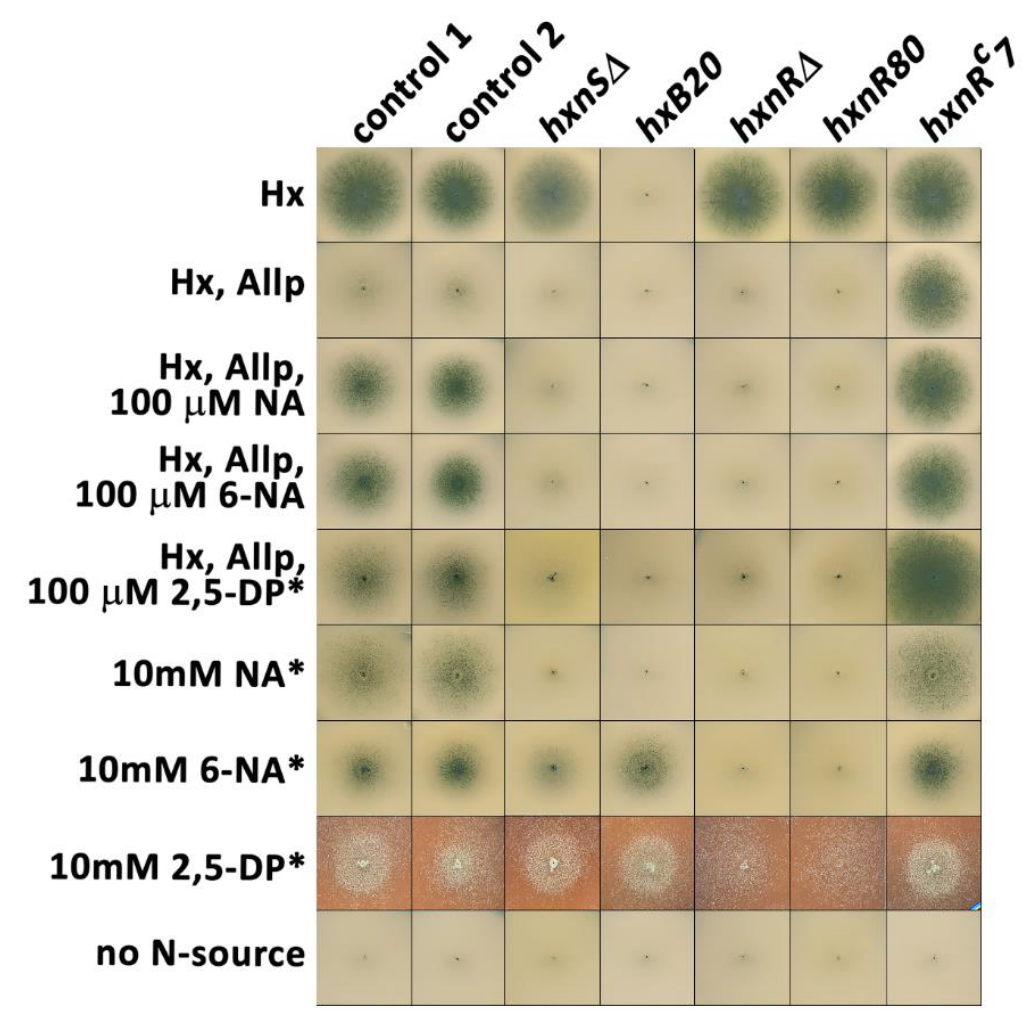

2. ábra: Mutáns törzsek növekedési képessége különböző nitrogénforrásokon (Ámon és mtsai., 2017) Minden oszlop felett a vizsgált törzs releváns mutációja található. Hx: 1mM Hx nitrogénforrás. Hx, Allp: 1mM Hx nitrogénforrás 5,5 $\mu \mathrm{M}$ Allp-lal kiegészítve, ami gátolja a PHI (HxA) müködését (viszont a HxnSt nem). Hx, Allp, $100 \mu \mathrm{M}$ NA: 1 mM Hx nitrogénforrás kiegészítve 5,5 $\mu \mathrm{M}$ Allp-lal és $100 \mu \mathrm{M}$ NA-al; Hx, Allp, $100 \mu \mathrm{M}$ 6-NA: $1 \mathrm{mM}$ Hx nitrogénforrás kiegészítve 5,5 $\mu \mathrm{M}$ Allp-lal és $100 \mu \mathrm{M}$ 6-NA-al. Hx, Allp, $100 \mu \mathrm{M} 2,5-$ DP: $1 \mathrm{mM}$ Hx nitrogénforrás kiegészítve 5,5 $\mu \mathrm{M}$ Allp-lal és $100 \mu \mathrm{M}$ 2,5-DP-el, $10 \mathrm{mM}$ NA, 10 mM 6-NA, 10 mM 2-5 DP: az egyedüli nitrogénforrás 10 mM NA, 6-NA, vagy 2,5-DP. A tenyészetek három napig $37^{\circ} \mathrm{C}$-on voltak inkubálva, kivéve a *-gal jelölt esetekben, ahol az inkubációs idő négy nap volt. Kontroll törzsek: szülöi

kontroll 1 (HZS.120), szülői kontroll 2 (TNO2 A21): az összes hxn gén tekintetében vad típusúak. Mutáns törzsek: hxnS $\Delta$ (HZS.548), hxB20 (HZS.135), hxnRA (HZS.136), hxnR80 (HZS.220), hxnRc7 (FGSC A872). A felhasznált törzsek teljes genotípusa megtalálható az 1. mellékletben. 


\section{CÉLKITÜZÉS}

A természetben számos mikroorganizmus képes a NA-at nitrogénforrásként hasznosítani, eddig mégis csak prokariótákban tanulmányozták a lebontás folyamatát. Eukariótákban ismeretlen a katabolizmus genetikai és molekuláris háttere, annak ellenére, hogy az A. nidulans modellszervezetről már az 1970-es években megállapították, hogy képes hasznosítani a NA-at egyedüli nitrogénforrásként, valamint számos NA-at hasznosítani nem képes mutánst izoláltak és vizsgáltak. Feltárták, hogy a lebontás első lépését, a NA 6-NA-vá történő átalakítását, a PHI xantin dehidrogenázzal vélhetően paralóg PHII enzim végzi. A NA-at nem hasznosító mutánsok között találtak regulátor-mutánsnak vélt törzseket is. A mutánsok klasszikus genetikai vizsgálatán túl azonban további tanulmányokat nem folytattak. Mivel az ezredfordulóra hozzáférhetővé vált számos modellorganizmus, így az A. nidulans genom szekvenciája is, új lehetőségek tárháza nyílt meg a NA hasznosítási út feltárásához. Kutatócsoportunk eukarióta szervezetben elsőként kezdett hozzá a NA katabolikus út tanulmányozásához. Azonosítottunk egy koregulációt mutató, hat génböl álló génklasztert a VI. kromoszómán (NDC1), mely a PHII enzimet kódoló hxnS gént, a NA hasznosítás transzkripciós faktorának génjét, a $h x n R$-t, valamint két transzporter gént ( $h x n P$ és $h x n Z$ ) és két oxigenázt kódoló gént ( $h x n T$ és $h x n Y$ ) hordozott. A $h x n$ gének deléciójával létrehozott mutánsok NA hasznosítási vizsgálata olyan eredményekkel szolgált, amely világosan jelezte, hogy a NA lebontásában eddig még nem azonosított további gének is részt vesznek. Jelen értekezésben célunk a NA hasznosításban részt vevő további gének azonosítása, regulációjuk vizsgálata, deléciós mutánsok létrehozása és jellemzése. Ezen kívül célul tűztük ki, hogy a deléciós mutánsokkal végzett analitikai vizsgálatok segítségével elkezdjük az útvonal köztes metabolitjainak azonosítását.

Célkitüzéseink részletesen az alábbiak voltak:

- Az 1970-es években izolált hxn6 mutáns törzs A. nidulans génbank transzformálásával célul tüztük ki további, NDC1 klaszteren kívüli, NA hasznosításban részt vevő gén(ek) azonosítását.

- Célul tűztük ki az azonosított új gén(ek) és a szomszédos gének regulációjának vizsgálatát kvantitatív valós idejü polimeráz láncreakcióval (RT-qPCR) történő transzkriptum analízissel vad típusú törzsben és $h x n R$ funkcióvesztéses mutánsban nem indukált és 6-NA-val indukált körülmények között. Az NDC1 génekkel mutatott koreguláció esetén a vizsgálat igazolja az új gén(ek) NA katabolikus útvonalhoz való tartozását, valamint a vizsgálat szomszédos génekre történő kiterjesztése lehetőséget nyújt egy új génklaszter azonosítására. 
- A genom adatbázisokban elérhető gombagenomok összehasonlító in silico elemzésével vizsgálni kívántuk az NDC1 klaszter génjeinek és az új gén(ek) kromoszóma lokalizációs mintázatát (szinténia vizsgálat) evolúciós összefüggések feltárása céljából.

- Amennyiben az azonosított új gén(ek) regulációja összhangban van az NDC1 klaszter génjeivel, akkor a szóban forgó gén(ek) kiütésével deléciós mutáns(ok) előállítását terveztük, amely(ek) növekedési tesztjei bizonyíthatják, hogy a deletált gén(ek) terméke valóban a katabolikus útvonalban szerepel. A növekedési teszteket NA-at és a kereskedelemben forgalmazott származékait tartalmazó táptalajok bevonásával terveztük elvégezni.

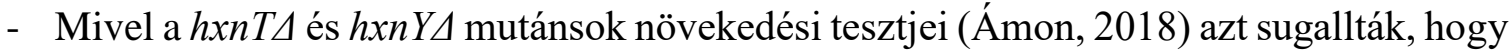
a NA lebontás nem egyetlen útvonalból áll, hanem alternatív útvonalak vesznek benne részt, célul tüztük ki $h x n S$, $h x n T$ és $h x n Y$ génekre nézve dupla- és tripla deléciós mutánsok létrehozását és ezek nitrogénforrás hasznosítási képességének vizsgálatát. A halmozottan deléciós mutánsok a HxnT és HxnY útvonalban betöltött szerepének tisztázásához is hozzájárulnak majd.

- Célul tűztük ki, hogy mielött in silico fehérje elemzést végzünk, kísérletes úton meghatározzuk az újonnan azonosított gén(ek) cDNS szekvenciáját és összehasonlítjuk a génbank által feltételezett cDNS szekvenciával.

- Célul tüztük ki továbbá az új gén(ek) által kódolt fehérje(ék) lehetséges funkcióinak feltárását in silico elemzéssel.

- További célkitűzésünk annak felderítése volt, hogy a katabolikus útvonal milyen intracelluláris térben zajlik. Ezt a lebontási útvonal már ismert és újonnan azonosított további génjeinek zöld fluoreszcens fehérjével (GFP) történő fúziójával és a fúziós fehérjét kifejező törzsek mikroszkópos vizsgálatával terveztük végrehajtani.

- Továbbá célul tűztük ki, hogy gázkromatográffal kapcsolt tömegspektrometria (GCMS) és folyadékkromatográffal kapcsolt tömegspektrometria (HPLC-MS) analízist végzünk, melyekhez további deléciós törzseket hozunk létre. Az összes deléciós mutáns metabolitjainak elemzésével célunk a katabolikus útvonal köztes metabolitjainak meghatározása és végső soron a teljes lebontási útvonal megismerése. 


\section{ANYAGOK ÉS MÓDSZEREK}

\subsection{Felhasznált mikroorganizmusok}

A kísérletek során alkalmazott $A$. nidulans és $E$. coli törzsek listája az 1. és 2. mellékletben található meg.

\subsection{Tenyésztési körülmények}

\subsubsection{A. nidulans tenyésztésére felhasznált táptalajok}

Minimál tápoldat (MM):

2\% (v/v) sóoldat; $1 \%(\mathrm{~m} / \mathrm{v})$ glükóz; kísérletenként változó nitrogénforrás $(\mathrm{pH} 6,8)$

Komplett tápoldat (CM):

2\% (v/v) sóoldat; $1 \%(\mathrm{~m} / \mathrm{v})$ glükóz; $0,2 \%(\mathrm{~m} / \mathrm{v})$ pepton; $0,15 \%(\mathrm{~m} / \mathrm{v})$ kazaminosavak; $0,1 \%$ $(\mathrm{m} / \mathrm{v})$ élesztőkivonat $(\mathrm{pH} 6,8)$

Szacharózos minimál tápoldat (SM):

2\% (v/v) sóoldat; $1 \%(\mathrm{~m} / \mathrm{v})$ glükóz; 34,2\% (m/v) szacharóz (pH 6,8)

Sóoldat:

$26 \%(\mathrm{~m} / \mathrm{v}) \mathrm{KCl} ; 26 \%(\mathrm{~m} / \mathrm{v}) \mathrm{MgSO}_{4} \times 7 \mathrm{H}_{2} \mathrm{O} ; 76 \%(\mathrm{~m} / \mathrm{v}) \mathrm{KH}_{2} \mathrm{PO}_{4} ; 5 \%$ (v/v) nyomelem-törzsoldat

Nyomelem-törzsoldat:

40 g/l Na-borát $\left(\mathrm{Na}_{2} \mathrm{~B}_{4} \mathrm{O}_{7} \times 10 \mathrm{H}_{2} \mathrm{O}\right) ; 400 \mathrm{mg} / \mathrm{l} \mathrm{CuSO}{ }_{4} \times 5 \mathrm{H}_{2} \mathrm{O} ; 714 \mathrm{mg} / \mathrm{l} \mathrm{FePO}_{4} ; 728 \mathrm{mg} / \mathrm{l}$ $\mathrm{MnSO}_{4} \times \mathrm{H}_{2} \mathrm{O} ; 800 \mathrm{mg} / 1 \mathrm{Na}_{2} \mathrm{MoO}_{4} \times 2 \mathrm{H}_{2} \mathrm{O} ; 8 \mathrm{mg} / \mathrm{ZnSO} \mathrm{Zn}_{4} \times 7 \mathrm{H}_{2} \mathrm{O}$

Vitaminok és felhasználási koncentrációjuk:

pantoténsav: $40 \mu \mathrm{g} / 1$; para-amino-benzoesav: $40 \mu \mathrm{g} / 1$; riboflavin: $50 \mu \mathrm{g} / \mathrm{l}$; piridoxin: $25 \mu \mathrm{g} / \mathrm{l}$; biotin: $0,1 \mu \mathrm{g} / 1$; tiamin: $50 \mu \mathrm{g} / 1$

Nitrogénforrások és felhasználási koncentrációjuk:

Hx: $1 \mathrm{mM}$; nátrium-nitrát: $10 \mathrm{mM}$; acetamid: $1 \mathrm{mM}$; urea: $5 \mathrm{mM}$; NA: $10 \mathrm{mM}$ nitrogénforrásként és $100 \mu \mathrm{M}$, illetve $1 \mathrm{mM}$ inducerként; 6-NA: $10 \mathrm{mM}$ nitrogénforrásként és 
$100 \mu \mathrm{M}$, illetve $1 \mathrm{mM}$ inducerként; 2,5-DP: $10 \mathrm{mM}$ nitrogénforrásként és $100 \mu \mathrm{M}$, illetve 1 $\mathrm{mM}$ inducerként

Gátlószerek és felhasználási koncentrációjuk:

Allp: $5,5 \mu \mathrm{M}$

\subsubsection{Escherichia coli tenyésztéséhez felhasznált táptalajok}

Luria-Bertani (LB) tápoldat: $10 \mathrm{~g} / 1$ tripton; $10 \mathrm{~g} / \mathrm{l} \mathrm{NaCl} ; 5 \mathrm{~g} / 1$ élesztőkivonat Táptalajok esetében a tápoldatot $2 \%(\mathrm{~m} / \mathrm{v})$ agarral egészítettük ki. A transzformánsok szelektálásához és felszaporításához a tápoldatot, illetve a táptalajt $50 \mu \mathrm{g} / \mathrm{ml}$ ampicillinnel is kiegészítettük.

\subsubsection{Az A. nidulans tenyésztési körülményei}

A tápoldatot a táptalajok esetében 2,5\% (m/v) agarral egészítettük ki. Szacharózos minimál táptalaj esetén $1 \%$ és $2,5 \%(\mathrm{~m} / \mathrm{v})$ agartartalmú táptalajt is alkalmaztunk. Az előbbit top agarként, az utóbbit normál tenyésztésre használtuk. Táptalajon történő növesztés során a felhasznált törzsekböl $0,01 \%$ (v/v) Tween 80 oldatban konídium-szuszpenziót készítettünk, majd ezekböl steril fogpiszkáló segítségével pontba oltottunk a táptalajra és $37{ }^{\circ} \mathrm{C}$-on inkubáltunk. A nitrogénforrás nélküli, a Hx nitrogénforrást tartalmazó, az Allp-lal kiegészített Hx-t tartalmazó és az Allp-lal kiegészített Hx nitrogénforrás mellett alkalmazott NA, 6-NA, 2,5-DP illetve nikotinamid (NAA) inducert tartalmazó táptalajok esetében 3 napos, a NA-at, 6NA-at, 2,5-DP-t, illetve NAA-ot nitrogénforrásként tartalmazó táptalajok esetében pedig 4 napos inkubációt alkalmaztunk. Folyadékkultúrák esetében $10^{8}$ konídiumot oltottunk $300 \mathrm{ml}$ MM tápoldatba és $37^{\circ} \mathrm{C}$-on $180 \mathrm{rpm}$ rázatás mellett inkubáltuk 12 órán át.

\subsection{Oldatok}

\subsubsection{DNS izoláláshoz felhasznált oldatok}

LETS puffer: 0,1 M LiCl; 0,01 M Na2EDTA; 0,2\% (m/v) SDS; 0,01 M Tris-Cl; (pH 7,4)

PCI: fenol:kloroform:izoamil-alkohol, 25:24:1

\subsubsection{E. coli kompetens sejt gyártáshoz és transzformálásához felhasznált oldatok}

SOB tápoldat: $2 \%$ tripton; $0,5 \%$ élesztőkivonat; $10 \mathrm{mM} \mathrm{NaCl} ; 2,5 \mathrm{mM}$ kálium-klorid $(\mathrm{KCl}), 10 \mathrm{mM}$ magnézium-klorid $(\mathrm{MgCl}) ; 10 \mathrm{mM}$ magnézium-szulfát $\left(\mathrm{Mg}_{2} \mathrm{SO}_{4} * 7 \mathrm{H}_{2} \mathrm{O}\right)(\mathrm{pH}$ $6,7-7,0)$ 
TB puffer: 10 mM PIPES; 15 mM kálcium-klorid; 250 mM KCl; 55 mM mangán-klorid; (pH 6,7)

GET oldat (100 ml): 2,5 ml 1M Tris (pH 7,5); 2 ml 0,5 M EDTA (pH 8); 0,9 g glükóz Alkalikus SDS oldat (100 ml): 88ml desztillált víz; 10 ml 20\% SDS; $2 \mathrm{ml} 10 \mathrm{M} \mathrm{NaOH}$ High Salt oldat (100 ml, pH 4): 29,4 g kálium-acetát $60 \mathrm{ml}$ desztillált vízben oldva; 11,5 ml jégecet; $28,5 \mathrm{ml}$ desztillált víz

\subsubsection{Aspergillus transzformáláshoz felhasznált oldatok}

TN1 oldat: $5,22 \%(\mathrm{~m} / \mathrm{v}) \mathrm{KCl} ; 0,735 \%(\mathrm{~m} / \mathrm{v}) \mathrm{CaCl}_{2}$

TN2 oldat: $60 \%(\mathrm{~m} / \mathrm{v})$ polietilén-glikol $4000($ PEG-4000); 1,214\% (m/v) Tris; 0,735\% (m/v) $\mathrm{CaCl}_{2}$

\subsubsection{Southern-blottoláshoz felhasznált oldatok}

Denaturáló puffer (500 ml): $10 \mathrm{~g} \mathrm{NaOH} ; 43,8 \mathrm{~g} \mathrm{NaCl}$

Neutralizáló puffer (500 ml): $125 \mathrm{ml}$ 2M Tris (pH 7,5); 43,8 g NaCl; 1 ml 0,5 M EDTA (pH 8)

$20 \times \mathrm{SSC}$ oldat $(500 \mathrm{ml}): 44,115 \mathrm{~g} \mathrm{Na}$-citrát; 87,66 g NaCl

\subsubsection{Southern-hibridizációhoz felhasznált oldatok}

A Dig-DNA Labeling and Detection Kit (Roche) felhasználásával, a gyártó leírása alapján készítettük el a felhasznált oldatokat.

\subsubsection{Horizontális gél elektroforézishez használt oldatok}

TAE futtatópuffer: $40 \mathrm{mM}$ Tris; $20 \mathrm{mM}$ ecetsav; $1 \mathrm{mM}$ EDTA; (pH 7,5)

Felvivő puffer: $0,5 \%(\mathrm{~m} / \mathrm{v})$ SDS; $40 \%(\mathrm{~m} / \mathrm{v})$ szacharóz; $0,1 \%(\mathrm{~m} / \mathrm{v})$ brómfenolkék; $50 \mathrm{mM}$ Tris; 10 mM EDTA; $(\mathrm{pH} 7,5)$

\subsubsection{HPLC-MS mérésekhez használt oldatok}

„A” eluens: acetonitril/víz/100 mM ammónium-formát (pH 3,4), 50/40/10\% (v/v)

„B” eluens: acetonitril/100 mM ammónium-formát (pH 3,4), 90/10\% (v/v)

\subsection{Kompetens $E$. coli sejtek készítése}

Kompetens E. coli sejtek készítéséhez egy telep E. coli JM109 (2. melléklet) inokulumot oltottunk $25 \mathrm{ml} \mathrm{LB}$ tápoldatba, majd 8 órán át $37{ }^{\circ} \mathrm{C}$-on $250 \mathrm{rpm}$ rázatással növesztettük. $\mathrm{Az}$ így felnövesztett kiindulási tenyészetből $15 \mathrm{ml}$-t $250 \mathrm{ml} \mathrm{SOB}$ tápoldatba oltottunk, majd $16{ }^{\circ} \mathrm{C}$ on 175 rpm rázatás mellett egy éjszakán keresztül növesztettük. Másnap, mikor a tenyészet a $0,7 \mathrm{OD}_{600}$ értéket elérte, a kultúrát $4{ }^{\circ} \mathrm{C}$-on 5000 rpm-en 10 percig centrifugáltuk. A sejteket 80 
ml TB pufferben felszuszpendáltuk, majd 8\% dimetil-szulfoxidot (DMSO) adtunk hozzá. Az így elkészített szuszpenziót $50 \mu$ l-es adagokban, folyékony nitrogénben fagyasztottuk, majd felhasználásig $-80{ }^{\circ} \mathrm{C}$-on tároltuk.

\subsection{Kompetens $E$. coli sejtek transzformálása}

A kompentens E. coli JM109 (2. melléklet) sejtek transzformálását Maniatis és mtsai (Maniatis és mtsai, 1982) által leírtak alapján végeztük. A sejteket jégen kiolvasztottuk, majd a ligálási elegyet $(7,5 \mu 1)$ a mikrocentrifugacsőbe mértük a kiolvasztott kompetens sejtekhez, majd szuszpendáltuk és 25 percig jégen inkubáltuk. Ezt követően az elegyet 2 percig hősokkoltuk $42{ }^{\circ} \mathrm{C}$-on, majd a mintákat azonnal jégen hütöttük. $800 \mu$ LB-oldatot mértünk a mintákra és 45 percig $37^{\circ} \mathrm{C}$-on inkubáltunk. Az inkubáció letelte után $50 \mu$ transzformáns elegyet szélesztettünk ampicillinnel kiegészített LB-táptalajra. A maradék tápoldatból a sejteket 5000 rpm-en történő 5 perces centrifugálással összegyüjtöttük, a felülúszót kiöntöttük. A visszamaradt folyadékban felszuszpendált sejteket egy másik, ampicillinnel kiegészített LBtáptalajra szélesztettük. A sejteket egy éjszakán át $37^{\circ} \mathrm{C}$-on inkubáltuk.

\subsection{Aspergillus transzformálás}

Az A. nidulans transzformálása Antal és mtsai (Antal és mtsai., 1997) alapján történt celofántenyészeten előállított (Ferenczy és mtsai., 1975, Kevei \& Peberdy, 1977) protoplasztokkal. A protoplasztok képzéséhez komplett táptalajra helyezett celofánra leoltott törzs 16 órás tenyészetét használtuk. A leoltást ecsettel végeztük frissen gyüjtött, $0,01 \%(\mathrm{v} / \mathrm{v})$ Tween 80-ban oldott konídiumszuszpenzióval. A protoplasztáláshoz 0,7 M KCl-oldatban feloldott Glucanex enzimkeveréket (Novozyme) használtunk, 40 mg/ml koncentrációban. A táptalajtól elválasztott celofánokat hármasával steril Petri-csészékbe helyeztük és 6-6 ml protoplasztáló folyadékot pipettáztunk rájuk. A protoplasztálást szobahőmérsékleten végeztük, maximum egy órán keresztül. A protoplasztokat $100 \mathrm{ml} \mathrm{0,7} \mathrm{M} \mathrm{KCl}$ oldatba mostuk le a celofánokról. A micéliális szennyeződéseket $100 \times 100 \mu \mathrm{m}$ rácsszerkezetű nylon szürő segítségével távolítottuk el, majd a protoplasztokat centrifugálással $\left(4000 \mathrm{rpm}, 14{ }^{\circ} \mathrm{C}\right.$-on, 25 perc) gyüjtöttük össze. Ezt követően $10 \mathrm{ml} \mathrm{0,7} \mathrm{M} \mathrm{KCl} \mathrm{oldatba} \mathrm{összemostuk} \mathrm{a} \mathrm{pelletet} \mathrm{és} \mathrm{újra}$ centrifugáltuk. Ezt követően a protoplasztokat óvatosan felszuszpendáltuk $1 \mathrm{ml} 0,7 \mathrm{M} \mathrm{KCl}$ oldatban. A szuszpenzióból 100-szoros hígítást készítettünk, amelynek protoplasztkoncentrációját Bürker-kamrás számolással állapítottuk meg. Mikrocentrifugacsőbe mértünk $5 \times 10^{6}$, illetve $5 \times 10^{7}$ sejtet, melyeket azután lecentrifugáltunk ( $2500 \mathrm{rpm}, 6$ perc), majd a pelletet $200 \mu 1$ TN1 oldatban felszuszpendáltuk és hozzáadagoltunk 1-10 $\mu$ g DNS-t és $55 \mu 1$ TN2 
oldatot. Az elegyet 30 percen át jégen inkubáltuk, majd $1 \mathrm{ml}$ TN2-t mértünk az elegyhez, és 5 percen át szobahőmérsékleten tartottuk. Ezt követően $10 \mathrm{ml}$ 0,7 M KCl-oldatot adtunk hozzá mosás céljából és centrifugáltuk (4000 rpm, 20 perc) a protoplasztokat, hogy a toxikus PEGtartalmat eltávolítsuk. A pelletet $1 \mathrm{ml} \mathrm{0,7} \mathrm{M} \mathrm{KCl}$ oldatba szuszpendáltuk és $50 \mathrm{ml} 40{ }^{\circ} \mathrm{C}$-os $1 \%$ $(\mathrm{m} / \mathrm{v}) \mathrm{SM}$ top agarral kevertük, majd $10 \mathrm{db}$ SM táptalajt tartalmazó csészére szétterítettük. A protoplasztokat $37{ }^{\circ} \mathrm{C}$-on regeneráltattuk. Csak azok a protoplasztok tudtak telepet képezni, melyekben a genomba rekombinálódott konstrukción hordozott szelekciós marker gén (pl. ribo $B^{+}$) kifejeződött és komplementálta az adott (pl. riboflavin) auxotrófiát.

\subsection{A. nidulans törzsek létrehozása keresztezéssel}

Megfelelő genotípussal rendelkező A. nidulans törzsek létrehozásához keresztezést alkalmaztunk. Olyan törzseket használtunk, melyek minden esetben legalább egy auxotrófiát okozó mutációt hordoztak, de a keresztezett törzsek egy esetben sem rendelkeztek ugyanazzal a mutációval, így heterokarion képzése során képesek komplementálni egymás auxotrófiáit. A keresztezni kívánt törzseket először sakktábla-szerü mintázatban CM táptalajra oltottuk, majd az összenőtt telepszélekből steril lándzsatű segítségével 4-4 agarkockát vágtunk ki, amit fejjel lefelé MM táptalajra helyeztünk át, ahol az auxotróf törzsek önmagukban nem képesek növekedni, de a hifaanasztomózissal (gombafonalak fúziója) létrejövő hetekarionok igen. Három napig $37{ }^{\circ} \mathrm{C}$-on inkubáltuk a telepeket, majd cellux segítségével oxigénmentesen lezártuk a Petri-csészéket, így teremtve meg a megfelelö körülményeket a szexuális életciklus számára. Ezt követően további 10-14 napig $37{ }^{\circ} \mathrm{C}$-on inkubáltuk a csészéket a szexuális szaporítóképletek (kleisztotéciumok) megjelenéséig. Keresztezésenként nyolc darab kleisztotéciumot gyüjtöttünk, melyeket MM táptalaj felszínén megtisztítottunk a ráragadt hifáktól, micélumoktól, illetve Hülle sejtektől, majd egyenként 200-200 $\mu 1$ 0,01\% (v/v) Tween 80 oldatba helyeztük őket. A mikrocentrifuga cső falához nyomva széttörtük a kleisztotéciumokat, így az aszkospórák kiszabadulhattak a folyadékba. Annak megállapítására, hogy szülői, vagy rekombináns kleisztotéciumokat gyüjtöttünk-e, az aszkospóra szuszpenziókból 5-5 $\mu$ l-t szélesztettünk MM táptalaj felszínére, amely semmilyen vitamint nem tartamazott, így csak a rekombinációval létrejövő prototróf utódok voltak képesek telepet képezni. A megfelelő aszkospóra szuszpenziók közül kiválasztottunk egyet, melyből 200szoros hígítást készítettünk, majd ebből 30, 40, illetve $50 \mu 1$ mennyiségéket CM táptalajra szélesztettünk steril üvegbot segítségével. Két nap, $37{ }^{\circ} \mathrm{C}$ inkubációt követően 
spóraszuszpenziókat készítettünk az egyedi telepekből és különbözö összetételü táptalajra oltottuk őket a pontos genotípusok megállapításának céljából.

\subsection{Nukleinsav-manipulációhoz felhasznált módszerek}

\subsubsection{Totál DNS kivonás A. nidulans-ból}

A komplett táptalajon felnövesztett $A$. nidulans törzsekböl $10^{8}$ konídiumot oltottunk 100 $\mathrm{ml}$, vitaminoldattal kiegészített folyékony MM tápoldatba, majd egy éjszakán át neveltük a törzseket. Az ezekből nyert micéliumtömeget szüréssel gyüjtöttük össze és folyékony nitrogénben történő fagyasztást követően kerámiamozsárban nitrogén alatt eldörzsöltük. Az eldörzsölt micéliumból kb. 0,1 g mennyiséget 0,8 ml LETS pufferrel, majd 0,8 ml PCI-vel mikrocentrifugacsőben vortexeltük, majd 13000 rpm-en 10 percig centrifugáltuk. A vizes fázist átmértük új mikrocentrifugacsőbe, majd azonos mennyiségü kloroform-izoamil-alkohollal (24:1) vortexeltük és 13000 rpm-en 10 percig centrifugáltuk. A vizes fázishoz egy újabb mikrocentrifugacsőben $10 \%$ (v/v) $3 \mathrm{M} \mathrm{Na}$-acetátot, illetve ekvivalens térfogatnyi izopropanolt mértünk, majd $-20^{\circ} \mathrm{C}$-on legalább 1 óráig inkubáltuk. Centrifugálás és $70 \%(\mathrm{v} / \mathrm{v})$ etanollal történő mosás után a DNS pelletre desztillált vízzel hígított RNáz-oldatot $(0,05 \mu \mathrm{g} / \mathrm{ml}$, Sigma Aldrich) mértünk és fél órán keresztül $37^{\circ} \mathrm{C}$-on inkubáltuk. Az RNS-szennyeződés eltávolítását követően az izolált DNS-t $-20^{\circ} \mathrm{C}$-on tároltuk.

\subsubsection{RNS kivonás A. nidulans-ból, cDNS szintézis}

Az RNS-tartalom izolálásához a szürt és szárazra csavart micéliumot folyékony nitrogén alatt, kerámiamozsárban púderfinomságúra dörzsöltük. Az RNS kivonáshoz az RNeasy Plus Mini Kit-et (Qiagen) használtuk a gyártó utasításai szerint. Egy-egy kivonáshoz kb. 100 mg biomasszát használtunk fel. Az izolált RNS mennyiségét és minőségét NanoDrop 1000 Spectrophotometer (Thermo Fisher Scientific) berendezéssel ellenőriztük. A cDNSszálakat a RevertAid First Strand cDNA Synthesis Kit (Thermo Scientific) segítségével szintetizáltuk, a gyártó instrukciói alapján. A cDNS szintéziséhez $1 \mu \mathrm{g}$ templát RNS-t, valamint oligo-dT és random indítószekvenciák 1:1 arányú keverékét használtuk. 


\subsubsection{Plazmid minipreparátumok készitése E. coli-ból}

A transzformált E. coli JM109 (2. melléklet) egyedi kolóniák sejtjeit $37{ }^{\circ} \mathrm{C}$-on egy éjszakán át tenyésztettük $2 \mathrm{ml}, 50 \mu \mathrm{g} / \mathrm{ml}$ ampicillinnel kiegészített LB tápoldatban. A tenyészetet mikrocentrifugacsövekbe mértük és a sejteket 5000 rpm-en történő 5 perces centrifugálással ülepítettük. A fellazított pellethez $0,1 \mathrm{ml}$ GET oldatot pipettáztunk, majd homogénre vortexeltük. Ezt követően $0,2 \mathrm{ml}$ alkalikus SDS-sel feltártuk a sejteket. A mikrocentrifugacsöveket a folyadék feltisztulásáig óvatos forgatással elegyítettük. Ezután 0,15 ml High Salt oldatot mértünk a csövekbe, melyeket ismét forgatással elegyítettünk a fehérje és lipid komponensek kicsapódása következtében keletkezett fehér csapadék megjelenéséig. 10 perc 13000 rpm-en végzett centrifugálás után a felülúszóhoz 1:1 arányban kloroform-izoamilalkohol (24:1) oldatot adtunk, melyet újabb 10 perc 13000 rpm-en történő centrifugálás követett. A vizes fázisból a plazmid DNS-t megegyező mennyiségü izopropanol hozzáadásával precipitáltuk, melynek a hatékonyságát 1 óra $-20^{\circ} \mathrm{C}$-os inkubálással növeltük. Ezután centrifugálás és $70 \%(\mathrm{v} / \mathrm{v})$ etanollal történő mosás következett, majd a DNS pelletet nyitott tetővel szobahőmérsékleten szárítottuk. A beszárított mintákat $50 \mu 1 \mathrm{RN}$-áz (10 $\mu \mathrm{g} / \mathrm{ml}$, Sigma Aldrich) tartalmú desztillált vízben vettük fel, majd a megfelelő restrikciós enzimekkel történő 1,5 órás emésztést követően $0,8 \%$-os agaróz gélen futtatva ellenőriztünk.

\subsubsection{DNS-minták agaróz gélelektroforézise}

A DNS-minták méret szerinti elválasztását agaróz gélelektroforézissel végeztük. Az eljáráshoz $0,8 \%(\mathrm{~m} / \mathrm{v})$ agaróz gélt és TAE futtatópuffert használtunk. A DNS láthatóvá tétele érdekében a gélhez $5 \mu \mathrm{g} / \mathrm{ml}$ etídium-bromidot adtunk. A mintákhoz a futtatás előtt $1 / 5$ térfogatnyi felvivő puffert mértünk. Az elektroforézist $100 \mathrm{~V}$ állandó feszültségen végeztük.

\subsubsection{DNS visszanyerése agaróz gélböl}

A gélelektroforézist követően a DNS-t tartalmazó sávokat UV fénnyel vizualizáltuk és szike segítségével kivágtuk. A DNS-t a Gel/PCR DNA Fragments Extraction Kit (Geneaid) felhasználásával tisztítottuk az agaróz gélből a gyártó utasításai alapján.

\subsubsection{DNS emésztése restrikciós endonukleázokkal}

A DNS-minták emésztéséhez restrikciós endonukleázokat (Thermo Scientific) használtunk a gyártó utasításai szerint.

\subsubsection{DNS-molekulák ligálása}

A DNS-ligálást T4 ligáz enzimmel végeztük (Thermo Scientific) a gyártó utasításai alapján. A vektor:inszert arányt tompa vég esetén 1:8-ra, azonos ragadós vég esetén 1:4-re, 
különböző ragadós végek esetén pedig 1:1 aránytól 1:4 arányig tetszőleges mértéküre állítottuk be. A ligálást $20^{\circ} \mathrm{C}$-on végeztük 5-14 órán keresztül.

\subsubsection{Polimeráz láncreakció (PCR)}

PCR-hez a PfuUltra II Fusion HS DNA Polymerase (Stratagene) enzimet használtuk a gyártó utasításai szerint. Egy reakció $50 \mu$ végtérfogatban 1-100 ng templát DNS-t és 20-20 pmol forward és reverz indítószekvenciákat tartalmazott. A PCR során a következő körülményeket alkalmaztuk: $98{ }^{\circ} \mathrm{C} 30$ másodperc elődenaturáció, 34 cikluson keresztül $98{ }^{\circ} \mathrm{C}$ 10 másodperc denaturáció, $58{ }^{\circ} \mathrm{C} 30$ másodperc indítószekvencia kötődés és $72{ }^{\circ} \mathrm{C} 30$ másodperc/kb polimerizáció, végül pedig $72{ }^{\circ} \mathrm{C} \mathrm{5-10} \mathrm{perc} \mathrm{utópolimerizáció.}$

\subsubsection{Kvantitatív valós idejü polimeráz láncreakció (RT-qPCR)}

$\mathrm{Az}$ 5.8.2. alfejezetben leírtak alapján létrehozott cDNS-minták RT-qPCR analízisét CFX96 Real Time PCR System (Biorad) berendezés és SYBR Green/Fluorescein qPCR Master Mix (Thermo Scientific) reakcióelegy felhasználásával végeztük. A reakció első lépése egy 94 ${ }^{\circ} \mathrm{C}$-os, 3 perces elődenaturáció, majd ezt követi 40 ciklus az alábbi paraméterekkel: $94{ }^{\circ} \mathrm{C} 15$ másodperc, $60{ }^{\circ} \mathrm{C} 60$ másodperc. Az adatok kiértékelése a „relative standard curve” eljárással (Larionov és mtsai., 2005) történt. Minden mérés legalább 3 technikai párhuzamossal történt.

\subsubsection{Southern-hibridizáció}

A restrikciós endonukleázokkal megemésztett (5.8.6. alfejezet) 5-10 $\mu \mathrm{g}$ DNS-mintákat agaróz gélelektroforézissel választottuk el (5.8.4. alfejezet), majd kapilláris módszerrel (Maniatis és mtsai., 1982) Hybond N membránra (GE Healthcare) blottoltuk. A jelölt próbák készítését és a detektálást a DIG DNA Labeling and Detection Kit-el (Roche) végeztük a gyártó utasításai alapján.

\subsection{A $h x n V$ és $h x n W$ cDNS szekvenciák felsokszorozása}

A $h x n V$ és $h x n W$ gének cDNS szekvenciájának ellenőrzéséhez vad típusú $A$. nidulans törzs (HZS.145) cDNS-ét alkalmazva sokszoroztuk fel a $h x n V$ és $h x n W$ gének szekvenciáját PCR segítségével. A $h x n V$ cDNS szekvenciájának esetében a „hxnV cDNA UJ EcoRI frw” és „hxnV cDNA PstI rev”, a hxnW cDNS szekvenciájának esetében pedig a „hxnW ispan frw” és „hxnW 3 UTR rev”indítószekvenciákat alkalmaztuk (4. melléklet). 


\subsection{A szubsztitúciós kazetták létrehozása a hxnS, hxnS/hxnT, hxnV, hxnX, hxn W, hxnM és $h x n N$ gének deléciójához}

A deléciós mutánsokat a „Double Joint PCR” módszer (Yu és mtsai., 2004) segítségével hoztuk létre három komponensü (,A”, „B” és „C”) deléciós kazetták készítésével (3. ábra). PCR segítségével felszaporítottuk az alábbi komponenseket:

„A” komponens: a deletálni kívánt géntől upstream elhelyezkedő, kb. 3 kb hosszúságú szekvencia (3. ábra). Az alkalmazott indítószekvenciák (4. melléklet) a következők voltak:

- hxnS és hxnShxnT: „hxnS rup frw” és „hxnS rup rev”

- hxnV, hxnWhxnV és hxnXhxnWhxnV: „hxnV upst frw” és „hxnV upst rev”

- hxnX: „hxnV AS frw” és „hxnV down nest rev”

- hxnW: „hxnW upst frw” és „hxnW upst rev”

- hxnM: „hxnM upst frw” és „hxnM upst rev”

- $h x n N$ : „hxnN upst frw” és „hxnN upst rev”

„B” komponens: a transzformáláshoz használatos vad típusú marker gén, mely komplementálja a recipiens törzs valamely auxotrófiáját (3. ábra). A marker gén amplifikálására speciális kiméra primereket használunk: a forward primer 5 , vége komplementer az upstream szekvencia nem kódoló szálának 3' végével, a reverse primer 3' vége pedig a downstream szekvencia kódoló szálának 5' végével. Az alkalmazott indítószekvenciák (4. melléklet) a következők voltak:

- hxnS: „hxnS rpaba kim frw” és „hxnS rpaba kim rev”

- hxnShxnT: „hxnS rpaba kim frw” és „hxnT paba kim rev”

- $h x n V:$,hxnV ribokim frw” és „hxnV ribokim rev”

- $h x n X$ : „hxnX ribokim frw” és „hxnX ribokim rev”

- hxnW: „hxnW ribokim frw” és „hxnW ribokim rev”

- hxnM: „hxnM ribokim frw” és „hxnM ribokim rev”

- hxnN: „hxnN ribokim frw” és „hxnN ribokim rev”

- hxnWhxnV: „hxnV ribokim frw” és „hxnW ribokim rev”

- hxnXhxnWhxnV: „hxnV ribokim frw” és „hxnX ribokim rev” 
„C” komponens: a deletálni kívánt géntől downstream elhelyezkedő, kb. 3 kb hossúságú szekvencia (3. ábra). Az alkalmazott indítószekvenciák (4. melléklet) a következők voltak:

- hxnS: „hxnS rdown frw” és „hxnS rdown rev”

- hxnShxnT: „hxnT down frw” és „hxnT down rev”

- hxnV: „hxnV down frw” és „hxnV down rev”

- a hxnX és hxnXhxnWhxnV: „hxnX down frw” és „hxnX down rev”

- hxnW és hxnWhxnV: „hxnW down frw” és „hxnW down rev”

- hxnM: „hxnM down frw” és „hxnM down rev”

- hxnN: „hxnN down frw” és „hxnN down rev”

A létrehozott „A”, „B” és „C” komponenseket Gel/PCR DNA Fragments Extraction Kit (Geneaid) segítségével megtisztítottuk a reakcióelegyben maradt indítószekvenciáktól, az enzimektől és a sóktól. A komponenseket egy újabb PCR-rel szereltük össze az „A”, „B” és „C” komponenseket 1:2:1 arányban használva templátként (3. ábra). Az alkalmazott indítószekvenciák (4. melléklet) a következők voltak:

- hxnS: „hxnS rup nest frw” és „hxnT rev”

- hxnShxnT: „hxnS rup nest frw” és „hxnT down nest rev”

- hxnV: „hxnV upst nest frw” és „hxnV down nest rev”

- hxnX: „hxnX upst nest frw” és „hxnW down rev”

- hxnW: „hxnV AS frw” és „hxnW down nest rev”

- hxnM: „hxnM upst nest frw” és „hxnM down nest rev”

- hxnN: „hxnN upst nest frw” és „hxnN down nest rev”

- hxnWhxnV: „hxnV upst nest frw” és „hxnW down nest rev”

- hxnXhxnWhxnV: „hxnV upst nest frw” és „hxnW down rev” 

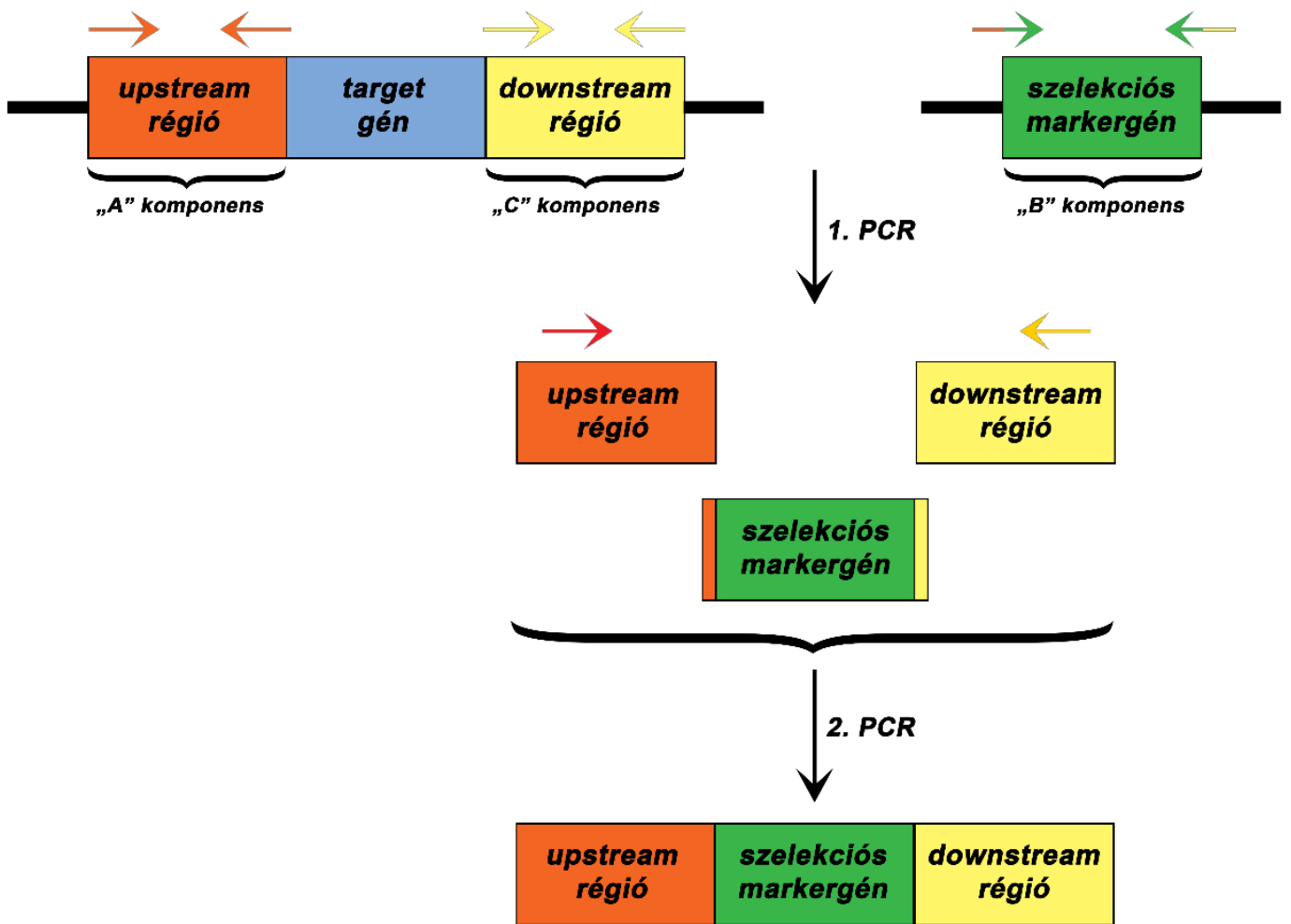

3. ábra: A szubsztitúciós kazetták elkészítésének sematikus ábrája.

Narancssárga téglalap (HR1): a deletálni kívánt géntől upstream található szekvencia, a szubsztitúciós kazetta

"A" komponense; amplifikációja "upstream frw" és "upstream rev" indítószekvencia párokkal történt

(narancssárga nyilak). Kék téglalap: a deletálni kívánt gén szekvenciája. Sárga téglalap (HR2): a deletálni kívánt géntől downstream irányban található szekvencia, a szubsztitúciós kazetta " $\mathrm{C}$ " komponense, amelyet a "downstream frw"-"downstream rev" indítószekvencia párok használatával készítettünk el (sárga nyilak). Zöld téglalap: szelekciót biztosító vitamin auxotrófia marker gén szekvenciája, a szubsztitúciós kazetta "B"

komponense; elkészítése olyan specifikus indítószekvenciákkal történt, amelyek egyik része a deletálni kívánt gén upstream (narancssárga-zöld nyíl narancssárga része) vagy downstream (zöld-sárga nyíl sárga része) szekvenciájával, másik része pedig a szelekciós marker gén szekvenciájával homológ (nyíl zöld része). A 3 komponens összeépítése a "nested upstream frw"(piros nyíl) és "nested upstream rev" (aranysárga nyíl) indítószekvenciákkal történt.

Az összeszerelés sikerességét agaróz gélelektroforézissel ellenőriztük, majd a terméket további tisztítás nélkül használtuk fel transzformáláshoz.

\subsection{GFP-fúziós konstrukciók létrehozása}

\subsubsection{A hxnV-gfp-t (C-terminális GFP-fúziós fehérjét) kódoló konstrukció létrehozása}

A GFP-fúziós konstrukció létrehozásához a pAN-HZS-1 (4. ábra, 3/A melléklet) plazmidot használtuk fel. A vektor tartalmazza a pantoB vad típusú szelekciós marker gént, mely a recipiens törzs pantoB100 mutációját képes komplementálni, ezáltal megszüntetni a törzs pantoténsav auxotrófiáját. Emellett tartalmazza a gpdA promóter után illesztett GFP-t 
kódoló szekvenciát és a trpC gén terminációs szekvenciáját. A HxnV-GFP fúziós fehérje létrehozásához genomi templátról felszaporítottuk az adott gén szekvenciáját („,hxnV NcoI frw” és „hxnV GFP linker NcoI rev” indítószekvenciák, 4. melléklet). A PCR-termék mindkét végén egy-egy NcoI hasítóhelyet hordozott, nem tartalmazta a stop kodont, viszont tartalmazott egy 9 AS hosszúságú „linker” peptid szekvenciát (LIDTVDLDS). Az így létrehozott szekvenciát a pAN-HZS-1 vektor NcoI hasítóhelyére klónoztuk megfelelő orientációba, létrehozva a pANHZS-12 vektort, melyet azután transzformációra használtunk fel (4. ábra, 3/A melléklet).
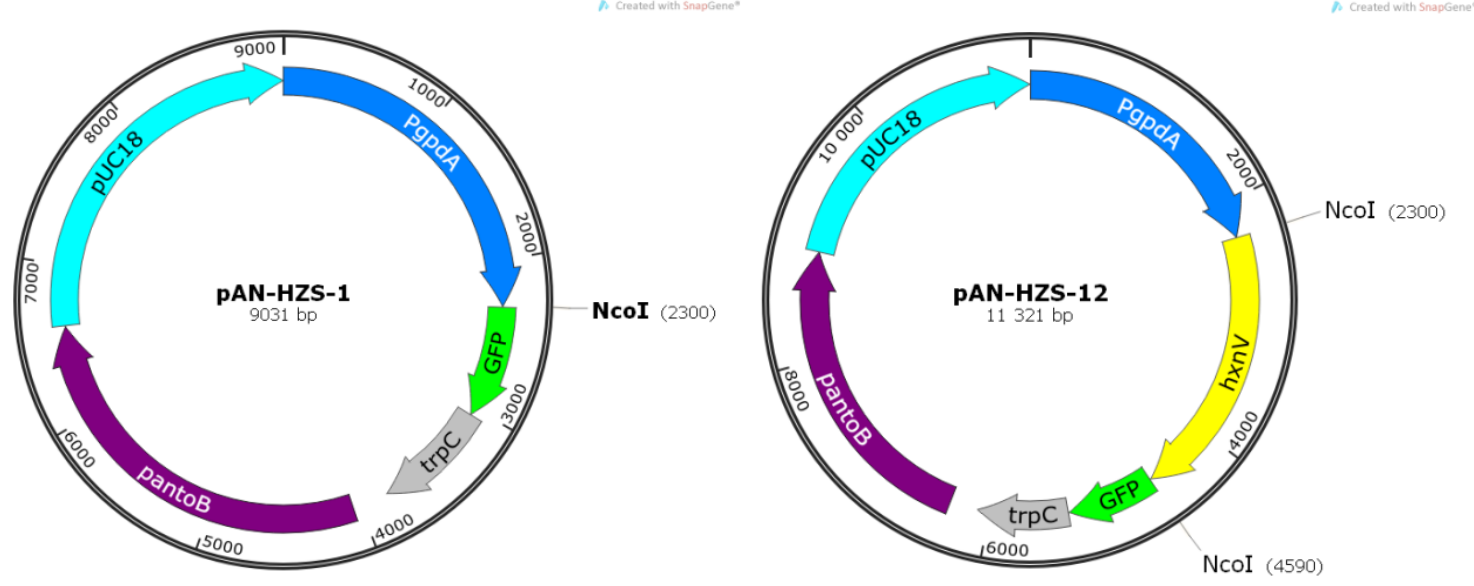

4. ábra: A hxn V-gfp-t kifejező konstrukcióhoz létrehozott pAN-HZS-12 vektor.

Bal oldalon látható a pAN-HZS-1 vektor, melynek NcoI hasítóhelyeire beklónoztuk a $h x n V$ szekvenciát, jobb oldalon pedig a kész pAN-HZS-12 vektor. Világoskék: E. coli replikációs origó, sötétkék: PgpdA promóter, sárga: NcoI hasítóhelyek közé klónozott $h x n V$ gént kódoló szekvencia, zöld: zöld fluoreszcens fehérjét kódoló szekvencia, szürke: $\operatorname{trp} C$ terminális szekvencia, lila: pantoB szelekciós marker gén.

\subsubsection{A gfp-hxnX-et (N-terminális GFP-fúziós fehérjét) kódoló konstrukció létrehozása}

Felszaporítottuk a $g f p$ szekvenciát az előző pontban bemutatott pAN-HZS-1 (5. ábra, 3/A melléklet) vektorról úgy, hogy a szekvencia ne tartalmazza a stop kodont („,1pGpd int frw” és „10GFP linker hmgB rev” indítószekvenciák, 4. melléklet). A HZS.145 törzs DNS-kivonatát használva templátként felszaporítottuk a hxnX gént („linker kim hxnX frw” és „hxnW down nest rev" indítószekvenciák, 4. melléklet). Mindkét PCR-termék tartalmazott egy 24 bázispár (bp) hosszúságú, átfedő szekvenciát, mely a fúzió létrehozásához szükséges, és tartalmaz egy 8 AS hosszúságú linker szekvenciát (LIDTVDLD) a fúzionált fehérjék közt. A két terméket PCR segítségével fúzionáltattuk (,,5GFP NcoI start frw” és „hxnX NotI rev” indítószekvenciák, 4. melléklet). A fúziós terméket NcoI és NotI restrikciós endonukleázokkal emésztettük és NcoI/NotI hasítóhelyekre klónoztuk pAN-HZS-1 vektorba. A létrehozott konstrukciót a továbbiakban pAN-HZS-13-nak neveztük (5. ábra, 3/A melléklet), melyet később transzformációra használtunk fel. 

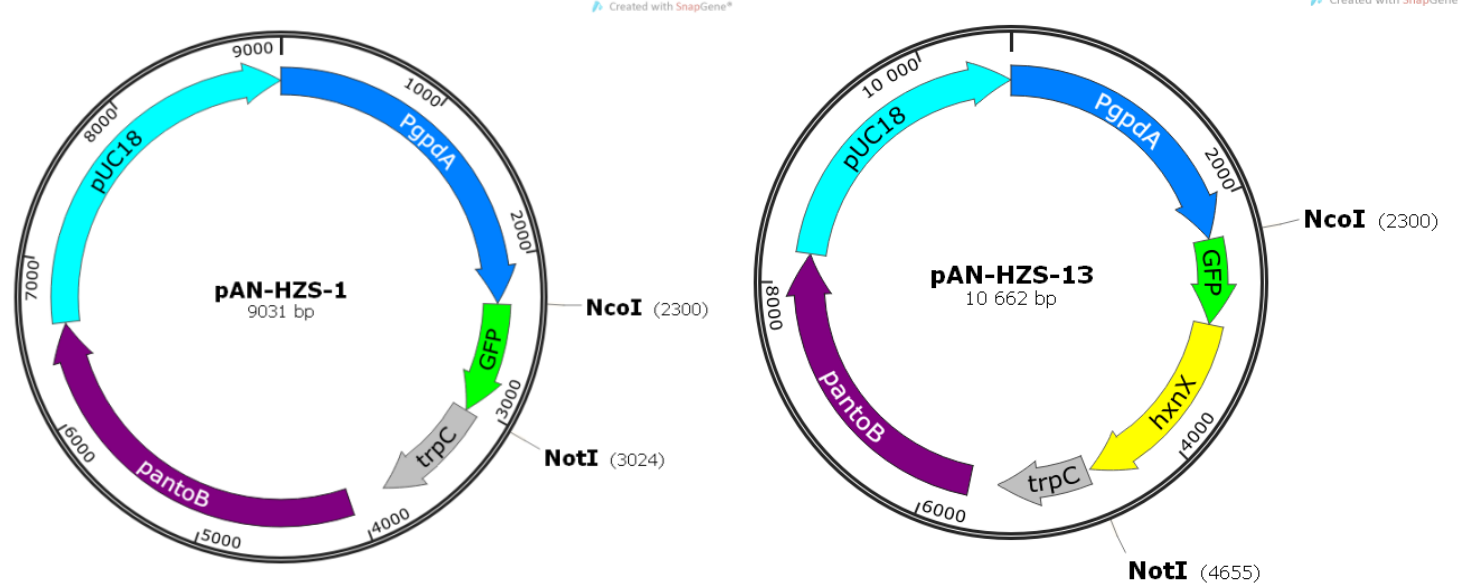

5. ábra: A $g f p-h x n X$-et kifejező konstrukcióhoz létrehozott pAN-HZS-13 vektor.

Bal oldalon látható a pAN-HZS-1 vektor, melynek NcoI/NotI hasítóhelyei közé beklónoztuk a $h x n X$ szekvenciát, jobb oldalon pedig a kész pAN-HZS-13 vektor. Világoskék: E. coli replikációs origó, sötétkék: PgpdA promóter,

sárga: NcoI/NotI hasítóhelyek közé klónozott hxnX gént kódoló szekvencia, zöld: zöld fluoreszcens fehérjét kódoló szekvencia, szürke: $\operatorname{trp} C$ terminális szekvencia, lila: pantoB szelekciós marker gén.

\subsection{In silico analízis}

\subsubsection{Ortológ keresés}

$\mathrm{Az}$ ortológ fehérjék keresésére a JGI Fungal Genome Portal adatbázisban (http://genome.jgi.doe.gov/programs/fungi/index.jsf) hozzáférhető több száz gombagenomot használtuk, ortológ keresés funkciót és az alapbeállításokat alkalmazva.

\subsubsection{Lokalizációs szignál keresés}

A lokalizációs szignál szekvenciák keresését a https://wolfpsort.hgc.jp/ szerver segítségével végeztük. A http://www.aspgd.org adatbázisból kigyűjtött fehérje szekvenciákat használtuk fel a lokalizációs szignálok keresése során.

\subsubsection{Homológia keresés}

A BLAST analíziseket a fehérjék szekvenciájának betáplálásával végeztük a https://blast.ncbi.nlm.nih.gov (blastp) program segítségével baktérium- és gomba genomok (kizárva az Aspergillaceae családot) közti kereséssel, az alapbeállításokat alkalmazva.

A PHYRE analízisek esetében is a fehérjék szekvenciáit adtuk meg és a http://www.sbg.bio.ic.ac.uk/phyre2/html/page.cgi?id=index programot használtuk a funkcionális homológok kereséséhez, az alapbeállításokat alkalmazva. 


\subsection{Mintaelőkészítés a fluoreszcens mikroszkópos vizsgálatokhoz}

A mikroszkópos preparátumok készítéséhez $10^{4}$ konídiumot oltottunk MM tápoldatba süllyesztett fedőlemez felületére és $37{ }^{\circ} \mathrm{C}$-on inkubáltuk 16-20 órán keresztül. A preparátumokban a GFP és RFP (vörös fluoreszcens fehérjével) fehérjéket Zeiss Axiolab A fluoreszcens mikroszkóp „Zeiss szürő szett 15” és „Zeiss szürő szett 09” szürők felhasználásával vizsgáltuk.

\subsection{Mintaelőkészítés és extrakció GC-MS és HPLC-MS analízishez}

A felnövesztett telepek konídiospóráit $0,01 \%$ (v/v) Tween 80 oldatba gyüjtöttük Petricsészében növesztett három napos telepekről, majd acetamiddal és vitaminokkal kiegészített MM tápoldatba oltottuk és $37^{\circ} \mathrm{C}$-on 24 órán át inkubáltuk. Az inkubációs idő letelte után szürtük és mostuk a tenyészeteket, majd 10 mM NA, vagy 6-NA nitrogénforrást tartalmazó MM tápoldatban további 16 órán át inkubáltuk $37{ }^{\circ} \mathrm{C}$-on. Ezt követően a micéliumokat szüréssel összegyüjtöttük. A fagyasztva szárított, majd elporított micéliumokból $20 \mathrm{mg}$ mennyiséget Eppendorf-csőbe mértünk és hozzáadtunk $1 \mathrm{ml}, 4{ }^{\circ} \mathrm{C}$ hőmérsékletű metanol/víz, 80/20\% (v/v) oldószerelegyet. Az extrakciót $4{ }^{\circ} \mathrm{C}$-on hajtottuk végre, 5 perc ultrahangos kezelés és az azt követő 1 perc vortexelés segítségével, mely lépéssorozatot háromszor ismételtünk. A mintákat centrifugáltuk (13000 rpm, 5 perc, $\left.4^{\circ} \mathrm{C}\right)$, majd a felülúszó összetételét vizsgáltuk GCMS és HPLC-MS módszerekkel.

\subsection{Mérési körülmények GC-MS analízis esetén}

A nyers extraktumokból $200 \mu$ l-t nitrogén áram alatt lepároltunk. A száraz maradékot $75 \mu 1$ piridinben oldottuk, majd hozzáadtunk $75 \mu 1 \mathrm{~N}$-metil-N-(terc-butil-dimetil-szilil)-trifluoracetamidot. Az elegyet 5 perc ultrahangos kezelést (Típus: 656, MTA KUTESZ, Magyarország) követően 30 percig $65{ }^{\circ} \mathrm{C}$ hőmérsékleten inkubáltuk. A fél óra származékképzési reakció után a szobahőmérsékletre hütött reakcióelegyből $1 \mu 1$ térfogatot injektáltunk a GC-MS rendszerbe. A GC-MS analízist Agilent 6890N gázkromatográffal kapcsolt Agilent 5973N tömegspektrométerrel hajtottuk végre (Agilent Technologies, USA). A GC-MS vizsgálat mérési körülményei a következők voltak: kapilláris oszlop: HP-5MS (30 m x $0,250 \mathrm{~mm} \times 0.25 \mu \mathrm{m}$ ); injektor hőmérséklete: $250{ }^{\circ} \mathrm{C}$; injektált mennyiség: $1 \mu 1$; vivőgáz: He ( $1 \mathrm{ml} /$ perc); hömérsékletprogram: $70^{\circ} \mathrm{C}, 2$ perc $\rightarrow 3,5^{\circ} \mathrm{C} /$ perc, $215^{\circ} \mathrm{C}, 15$ perc $\rightarrow 3,5^{\circ} \mathrm{C} /$ perc, $250{ }^{\circ} \mathrm{C}$, 0 perc $\rightarrow 20{ }^{\circ} \mathrm{C}$ /perc, $300{ }^{\circ} \mathrm{C}, 5$ perc; tömegtartomány: $40-700 \mathrm{Da}$; analizátor hőmérséklete: $150^{\circ} \mathrm{C}$; ionforrás hőmérséklete: $230^{\circ} \mathrm{C}$. 


\subsection{Mérési körülmények HPLC-MS analízis esetén}

A nyers extraktumok HPLC-MS analízisét egy dimer pumpával, gázmentesítő egységgel, UV detektorral, oszlop termosztáttal és automata mintaadagolóval felszerelt Dionex Ultimate 3000 UHPLC rendszerhez (Thermo Scientific, USA) kapcsolt hibrid kvadrupólOrbitrap Q Exactive Plus tömegspektrométerrel végeztük (Thermo Scientific, Germany). Az 5 $\mu 1$ minták elválasztását $25{ }^{\circ} \mathrm{C}$-on termosztált, $150 \mathrm{~mm}$ x 4,6 mm, $5 \mu \mathrm{m}$ szemcseátmérőjü LUNA-HILIC (Phenomenex) oszlopon, grádiens eluensárammal valósítottuk meg 0,7 ml/perc áramlási sebességgel. $\mathrm{Az}$ „A” eluens acetonitril/víz/100 mM ammónium-formát ( $\mathrm{pH} 3,4)$, 50/40/10\% (v/v) arányú elegye, míg a „B” eluens acetonitril/ammónium-formát ( $\mathrm{pH} 3,4)$, 90/10\% (v/v) arányú elegye volt. A grádiensprogramot 4 percig tartó 95\% „B” eluens tartalommal indítottuk, mely 3 perc alatt 50\%-ra csökkent. Ezt követően a mozgófázis összetételét 4 percen keresztül ezen az értéken tartottuk, majd további 1 perc alatt visszaállítottuk a kiindulási értékre és a nyomás stabilizálódásáig ( 8 perc) ezen az értéken hagytuk. A mintákból $5 \mu$ l-t injektáltunk a HPLC-MS rendszerbe. A nyers extraktumok HPLCUV analízise során a minták UV-elnyelését 260, és $330 \mathrm{~nm}$ hullámhosszon követtük. A tömegspektrométer irányítását és az adatgyüjtést az Xcalibur ${ }^{\mathrm{TM}}$ 2.2.1, az eredmények kiértékelését és a fökomponens analízist pedig a Compound Discoverer 2.1 (Thermo Fisher Scientific) szoftverekkel végeztük. A tömegspektrométer beállításai a következők voltak: ionforrás: HESI; ionizáció: pozitív mód; spray feszültség: $3500 \mathrm{~V}$; porlasztógáz áramlási sebessége: 40 (tetszőleges egység); szárítógáz áramlási sebessége: 65 (tetszőleges egység); kapilláris hőmérséklet: $350{ }^{\circ} \mathrm{C}$; S lencsék rádiófrekvenciás beállítása: $50 \mathrm{~V}$; felbontás: 70000 . A tömegspektrometriás mérések full scan-ddms2 módban történtek. A vegyületeket az 50-500 Da tömegtartományban detektáltuk és a kromatográfiás csúcsokban a legintenzívebb 5 protonált molekulaion fragmentációját hajtottuk végre. 


\section{EREDMÉNYEK ÉS ÉRTÉKELÉSÜK}

\subsection{Az NDC1 klasztergéneken kívül további, nikotinsav lebontásban szerepet játszó gének keresése}

Az 1970-es években a NA-at nitrogénforrásként nem hasznosító mutánsokon végzett klasszikus genetikai vizsgálatok világosan jelezték, hogy léteznek olyan allélok, amelyek vagy laza kapcsoltságban állnak az általunk azonosított NDC klaszter (NDC1) génjeivel, vagy nem mutatnak kapcsoltságot velük (J. Kelly és C. Scazzocchio személyes közlése). Mivel a szóban forgó mutánsok közül egyetlen törzs, a hxn6 mutáns (CS308) fennmaradt (C. Scazzocchio személyes törzsgyüjteményében), lehetőségünk nyílt arra, hogy génbank transzformálás útján azonosítsuk a hxn6 allélt, majd vizsgáljuk a hxn6 allél vad típusú gén és a szomszédos gének expresszióját annak reményében, hogy az NDC1 génjeivel koregulációt mutató gén(ek)re találunk. Ezen kívül in silico elemzéssel az azonosított gén(ek) és az NDC1 klaszter génjeinek egymáshoz viszonyított lokalizációjának konzerváltságát (szinténia vizsgálat) is vizsgálni kívántuk, amely a nikotinsav katabolikus út evolválódásáról nyújthat információt.

6.1.1. In vivo megközelités - hxn6 mutáns transzformálása A. nidulans génbankkal, a hxn6 mutáció azonositása és az NDC2 génklaszter felfedezése

Az 1970-es évekből fennmaradt hxn6 törzs (CS308) olyan NA-at nem hasznosító mutáns volt, amelyben a mutáns allél a klasszikus genetikai elemzések alapján nem az NDC1 klasztergénekhez térképeződött a genomban, hanem azoktól nagyjából 40 kb távolságra (Joan Kelly személyes közlés). A hxn6 törzs azért volt rendkívül fontos a NA katabolizmus vizsgálata számára, mert nem képes hasznosítani sem a NA-at, sem pedig a 6-NA-at. Ilyen jellegü fenotípust korábban csak a $h x n R$ transzkripciós faktor funkcióvesztéses mutációja, vagy deléciója esetében tapasztaltunk. Ezek alapján úgy gondoltuk, hogy a hxn6 allél vad típusú megfelelője a NA katabolizmus esszenciális komponensét kódolhatja. A hxn6 allél azonosításához a CS308 törzsbe genetikai keresztezéssel (CS308×HZS.125) pyrG89 mutációt vittünk be, hogy lehetőségünk legyen a pyr4 (a pyrG ${ }^{+}$gén megfelelöje Neurospora crassa-ban) szelekciós marker gént tartalmazó génbank vektorok transzformációval történő bejutásának szelekciójára. A génbank plazmid szerkezetének bemutatása a 3/B mellékletben található.

A hxn6 pyrG89 törzset (HZS.257) $5 \mu \mathrm{g}$ A. nidulans génbank DNS-el (Osherov \& May, 2000) transzformáltuk, majd a transzformánsokat 6-NA nitrogénforrást igen (csak hxn6-ot szupresszáló transzformánsok nőhetnek), de uracilt és uridint nem tartalmazó táptalajon (szelektáltunk a pyr4-t kifejező transzformánsokra) növesztettük. Egyetlen transzformáns 
telepet izoláltunk, amelyen plazmid menekítést hajtottunk végre totál DNS kivonást (5.8.1. alfejezet) követően a totál DNS E. coli JM109 törzsébe (2. melléklet) történő transzformálásával (5.5. alfejezet). A kapott E. coli transzformáns törzsek közül négy telepből készítettük plazmid minipreparátumot (5.8.3. alfejezet), amelyek BamHI, EcoRI, EcoRV, HindIII, XbaI, és XhoI restrikciós profilja megegyező volt (nem mutatott adat). Az egyik plazmid preparátumból létrehozott HindIII szubklónok (pBluescript SK plazmidba) T3, T7, és „walking” indítószekvenciákkal (4. melléklet) történő szekvenálásával (LGC Genomics) azonosítottuk azt a genomi régiót, amely a hxn6 allélt komplementálta (6. ábra). Az eredmények alapján a génbank plazmid egy 8256 bp-os genomi DNS-t hordozott, amely az 5' és a 3' végén részlegesen hordozta az AN9159 és az AN9162 gént, köztük pedig 3 teljes ORF-et találtunk, az AN11187-et, az AN11172-t és az AN9161-et (6. ábra). Az AN11187 gén és az NDC1 klaszter legközelebbi génje $(h x n Z)$ közötti távolság 40748 bp. Ez a távolság összhangban van a genetikai keresztezésekkel mért távolsággal, amelyet a hxnS és $h x n 6$ lókuszok között találtak.

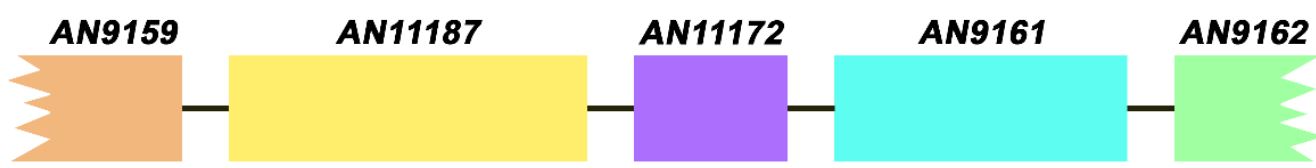

6. ábra: A génbank plazmid szekvenálása során azonosított genomi régió sematikus ábrázolása. A 8256 bp hosszú genomi régió határain részlegesen van jelen az AN9159 és AN9162 gén (megszakított dobozok), és ezek között az AN11187, AN11172 és AN9161 gének találhatóak (egész dobozok).

Annak lehetőségét kizártuk, hogy a plazmidon részlegesen jelen lévő gének okozták a hxn6 komplementációját, így csak az AN11187, AN11172 és AN9161 géneket szekvenáltuk meg a hxn6 törzsböl és a szekvenciákat összehasonlítva az adatbank megfelelő szekvenciáival (indítószekvenciákat lásd 4. mellékletben) az AN11187 génben találtunk egy nukleotid (nt) eltérést, amely a hxn6 allélben G1171A mutációt okozott. A mutáció az AN11187 cDNS szekvenciája alapján (lásd 6.2. alfejezet) lefordított fehérjében W296STOP (nonsense) mutációnak felel meg. Ez alapján a 629 AS hosszúságú fehérje helyett a hxn6 törzsben csak egy 295 AS-ból álló csonkolt fehérje íródik át, amely funkcióvesztést okoz az AN11187 géntermékben.

Ezt követően transzkriptum analízist végeztünk (relatív „standard curve” módszerrel elemzett RT-qPCR analízissel) az AN11187 génen, amelyet kiterjesztettünk a szomszédos AN9159 és AN11172 génekre is. A transzkriptum elemzést vad típusú és $h x n R \Delta$ törzseken végeztük el nem indukált (a tenyésztés neutrális, se nem represszáló, se nem indukáló acetamid nitrogénforráson történt 10 órán át) és indukált (neutrális acetamid nitrogénforráson történő 8 
óra tenyésztést követően a tápoldathoz $1 \mathrm{mM}$ 6-NA-at adagoltunk és további 2 órán át inkubáltunk) körülmények között. Az AN11187 és az AN11172 is koregulációt mutatott az NDC1 klasztert reprezentáló hxnS génnel, tehát mindkét gént a NA katabolikus útvonal résztvevőinek tekinthettük (7. ábra). Az AN9159 gén a 6-NA indukciótól és a HxnR transzkripciós faktortól teljesen független módon fejeződik ki (7. ábra), ezért ezt a gént nem tekintettük a NA katabolikus út tagjának. Ezt követően vizsgáltuk az AN11172 géntől upstream elhelyezkedő három szomszédos gén (AN9161, AN9162 és AN9163) kifejeződését is. Közülük csak az AN11172-vel közvetlen szomszédságban levő AN9161 gén mutatott $h x n S$-el megegyező regulációt, a másik két gén azonban 6-NA inducertől és HxnR-től független kifejeződést mutatott (7. ábra). Az eredmények alapján elmondhatjuk, hogy azonosítottunk egy 3 génből (AN11187, AN11172 és AN9161) álló klasztert (a továbbiakban NDC2 klaszter), amely génjei koregulációt mutatnak az NDC1 klaszter génjeivel, és vélhetőleg szerepet játszanak a NA katabolizmusában. Az AN11187 gént hxnV-nek, az AN11172 gént hxnW-nek, az AN9161 gént pedig $h x n X$-nek neveztük el.

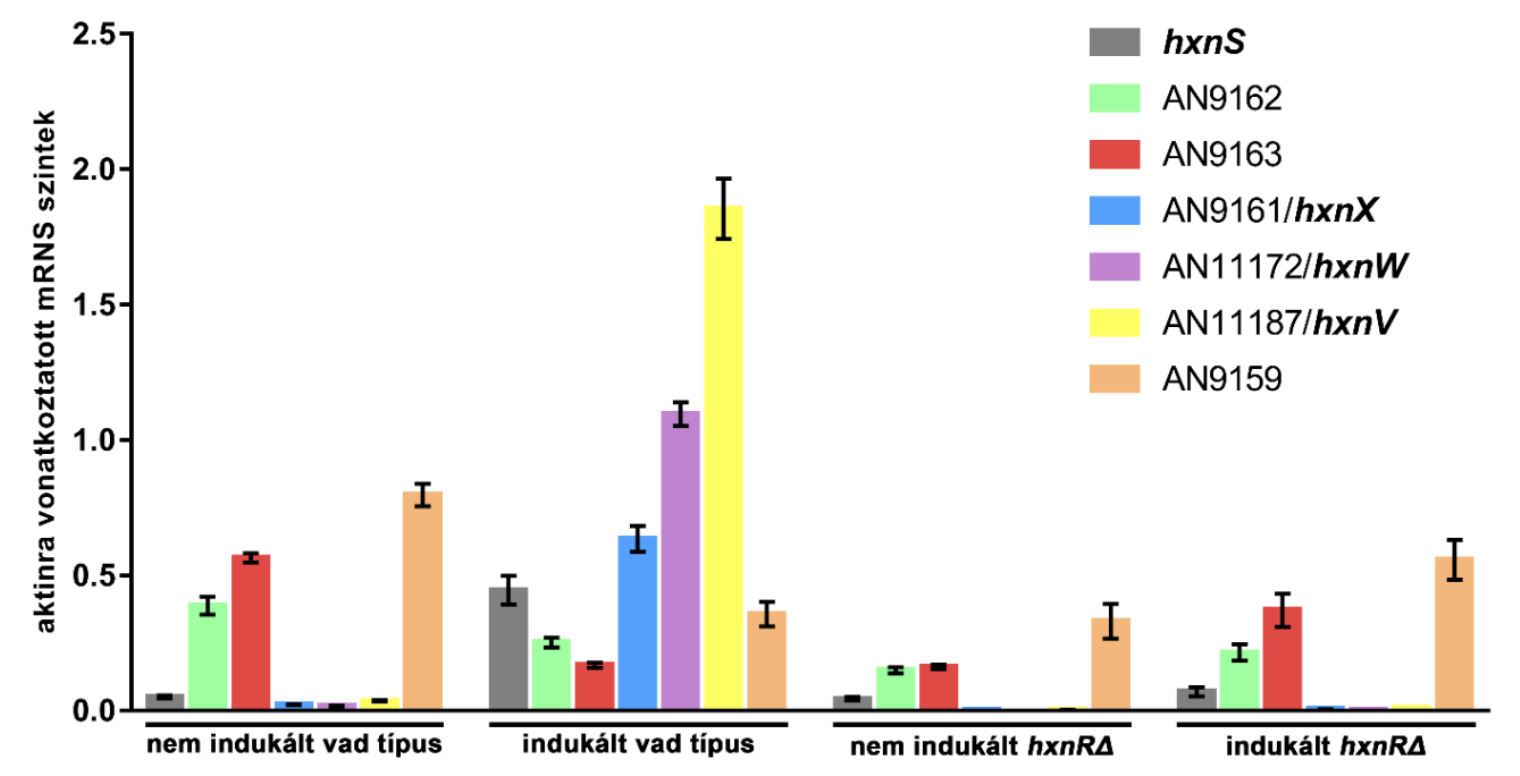

7. ábra: A hxnV, hxnW és $h x n X$ gének, valamint a szomszédos gének génkifejeződésének vizsgálata RTqPCR-rel.

Az AN11187 ( $h x n V)$, AN11172 (hxnW) és AN9161 (hxnX) gének, valamint a velük szomszédos AN9162, AN9163 és AN9159 gének expressziós szintje vad típusú és $h x n R \Delta$ ( $h x n R$ deléciós) törzsekben nem indukált és indukált (1 mM 6-NA-val végzett indukció) körülmények között. A nem indukált körülmény 10 óra acetamidon történő tenyésztés volt. Az indukált körülmény esetén 8 óra acetamidon történő tenyésztést követően a tápoldatot 1 mM 6-NA-val egészítettük ki, majd további 2 órán át inkubáltunk. Háztartási génként a gamma-aktint (acnA), kontrollként pedig a $h x n S$ gént használtuk. Az RT-qPCR eredményeket a „relative standard curve” elemzési módszerrel kaptuk. Az ábrán három biológiai ismétlés szórási eredményeit tüntettük fel. 
6.1.2. In silico megközelités - a hxn gének egymáshoz viszonyított genomi elrendezödésének vizsgálata

Szinténia összefüggést mutató ortológkeresési eljárással mintegy 200 elérhető Pezizomycotina genomot vizsgáltunk meg a JGI Fungal Genome Portal adatbázis felületén. Fajonként kigyüjtöttük az NDC1 és NDC2 gének ortológjait a genomi környezetüket is mutató adatokkal együtt és összehasonlító vizsgálattal elemeztük a gének előfordulását és relatív sorrendjét. Azon kívül, hogy a vizsgált gombagenomokban az NDC1 és NDC2 klaszterek nem mindig különültek el egymástól, hanem általában egyetlen klaszterbe szerveződtek, felfigyeltünk arra, hogy bizonyos gének génpárokba rendeződve erös konzerváltságot mutatnak. Érdekes módon egyes esetekben a génpárok tagjai általunk $h x n$-ként nem azonosított gének voltak. A $h x n S$ a $h x n T$-vel, a $h x n P$ a $h x n Y$-nal, a $h x n W$ az AN6518-cal, a $h x n V$ pedig az AN10833-mal alkotott génpárokat (1. Táblázat). A 6.1.3. alfejezetben részletesen leírt módon transzkriptum analízissel igazoltuk, hogy az I. kromoszómán található AN6518 és az AN10833 is a NA katabolikus út szabályozása alatt áll, azaz feltehetően részei a NA katabolikus folyamatnak. Az AN6518-at hxnM-nek, az AN10833 gént pedig $h x n N$-nek neveztük el.

1. Táblázat: Az erősen konzervált génpárokat reprezentáló néhány faj, amelyek hxn génjeinek genomi elrendeződését a 8 . ábrán mutatjuk be.

\begin{tabular}{|c|c|}
\hline Génpár & Példa faj \\
\hline$x n T$ & $\begin{array}{l}\text { Botryosphaeria dothidea, Pyrenophora tritici-repentis, Phaeosphaeria } \\
\text { nodorum, Paracoccidioides brasiliensis, Hysterium pulicare, } \\
\text { Aspergillus. terreus, A. niger, A. carbonarius, A. nidulans }\end{array}$ \\
\hline$h x n P-h x n Y$ & $\begin{array}{l}\text { Talaromyces stipita, Nectria haematococca, Grosmannia clavigera, } \\
\text { Gibberella moniliformis, Glomerella graminicola, A. terreus, A. oryzae, } \\
\text { A. niger, A. flavus, A. carbonarius, A. aculeatus, A. nidulans }\end{array}$ \\
\hline $\begin{array}{l}h x n W-\mathrm{AN} 6518 \\
(h x n M)\end{array}$ & $\begin{array}{l}\text { Tuber melanosporum, Pa. brasiliensis, Gi. moniliformis, } G l \text {. } \\
\text { graminicola, Nectria haematococca }\end{array}$ \\
\hline $\begin{array}{l}h x n V-\mathrm{AN} 10833 \\
(h x n N)\end{array}$ & $\begin{array}{l}\text { Bo. dothidea, Tu. melanosporum, Ph. nodorum, Pa. brasiliensis, } H . \\
\text { pulicare, Gr. clavigera, Gi. moniliformis, Gl graminicola }\end{array}$ \\
\hline
\end{tabular}

A vizsgálatba bevont genomok közül kiválasztottuk azokat, amelyek a klasztergének eltérő elrendeződését reprezentálják (6. melléklet) és sematikus ábrán (8. ábra) foglaltuk össze klasztereiket annak bemutatására, hogy a klasztert hordozó genomi DNS szakasz gyakori génátrendeződések színtere. 


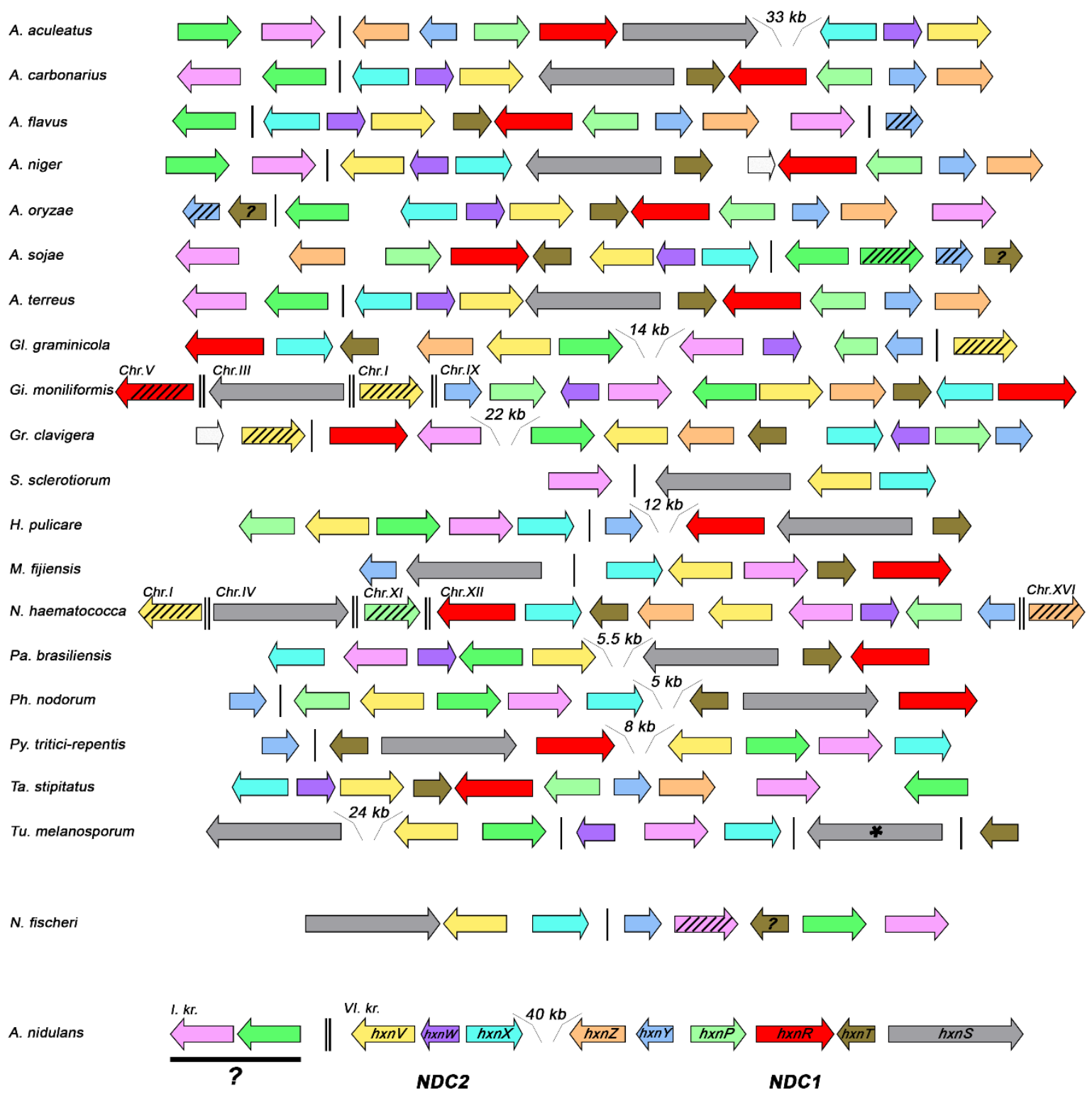

8. ábra: A JGI adatbázis felületről gyűjtött klasztergén ortológok genomon belüli szerveződésének sematikus ábrázolása különböző reprezentatív Pezizomycota fajokban.

Az azonos szín az ortológ géneket jelöli. A színkódok az A. nidulans ábrázolásra felírt gének ortológjait jelölik. A sávozott nyilak a duplikálódott géneket, a csillagozottak a pszeudogéneket, a kérdőjelesek pedig az adott génnel homológ géneket jelölik. A két függőleges vonal kromoszómahatárokat jelöl, míg az egy függőleges vonal a szoros kapcsoltság hiányára utal ugyanazon kromoszómán. Az A. nidulans-ban kérdőjel fölött található zöld és halvány lila színekkel jelzett gének az AN10833 (későbbiekben $h x n N$ ) és az AN6518 (későbbiekben hxnM) géneket jelölik. A fehér színnel jelzett gén egy bakteriális eredetü nitroreduktáz (AN8360), amely nem mutat koregulációt az NDC1 génekkel, nem része a NA katabolikus útvonalnak (Ámon és mtsai., 2017). A feltüntetett fajok az ábrázolás sorrendjében a következőek: Aspergillus aculeatus, Aspergillus carbonarius, Aspergillus flavus, Aspergillus niger, Aspergillus oryzae, Aspergillus sojae, Aspergillus terreus, Glomerella graminicola, Gibberella moniliformis, Grosmannia clavigera, Sclerotinia sclerotiorum, Hysterium pulicare, Mycosphaerella fijiensis, Nectria haematococca, Paracoccidioides brasiliensis, Phaeosphaeria nodorum,

Pyrenophora tritici-repentis, Talaromyces stipitatus, Tuber melanosporum, Botryosphaeria dothidea, Neosartorya fischeri, Aspergillus nidulans. 
Az ábrázolt gének lokalizációjának mintázata azon kívül, hogy gyakori genomátrendeződésekről árulkodik, duplikációs és deléciós eseményekről is tanúskodik. Már az NDC1 klasztergének különböző fajokban történő előfordulásának összehasonlító elemzése során kiderült, hogy számos gombacsoportból hiányoznak kulcsfontosságú klasztergének (pl. a transzkripciós faktort kódoló $h x n R$ gén, és/vagy a $h x n S$, amely a PHII-t kódolja). Ez alapján azt feltételezhetjük, hogy néhány gombafaj nem képes a NA-at nitrogénforrásként hasznosítani (Ámon és mtsai., 2017). Jelenleg folyik olyan adatelemzés (kollaborációs partnerek bevonásával), amely annak megválaszolására irányul, hogy vajon a génklaszter létrejöttét követően a gombafajok evolúciójával rendeződött-e át a klaszter a jelenleg látható sokféle elrendezést eredményezve, vagy pedig folyamatosan, egymástól függetlenül evolválódott (konvergens evolúció). Az értekezésben be nem mutatott kezdeti elemzések alapján ez utóbbi esemény valószínüsíthető.

6.1.3. Az AN6518 és AN10833 gének és az őket határoló szomszédos gének regulációjának vizsgálata - az NDC3 génklaszter felfedezése

Annak kiderítésére, hogy az in silico módszerrel azonosított AN6518 és AN10833 gének szerepet játszanak-e a NA lebontási útvonalban, relatív „standard curve” módszerrel elemzett RT-qPCR kísérleteket végeztünk nem-indukált és indukált (1 mM 6-NA-val végzett indukció) körülmények között tenyésztett (a körülmények megegyeznek a 6.1.1. fejezetben részletezettekkel) $h x n R^{+}$és $h x n R \Delta$ allélt hordozó törzsek cDNS-ével. A két feltételezett $h x n$ gén mellett a vizsgálatba bevontuk a velük szomszédos géneket is (AN6517 és AN10825) (9. ábra).

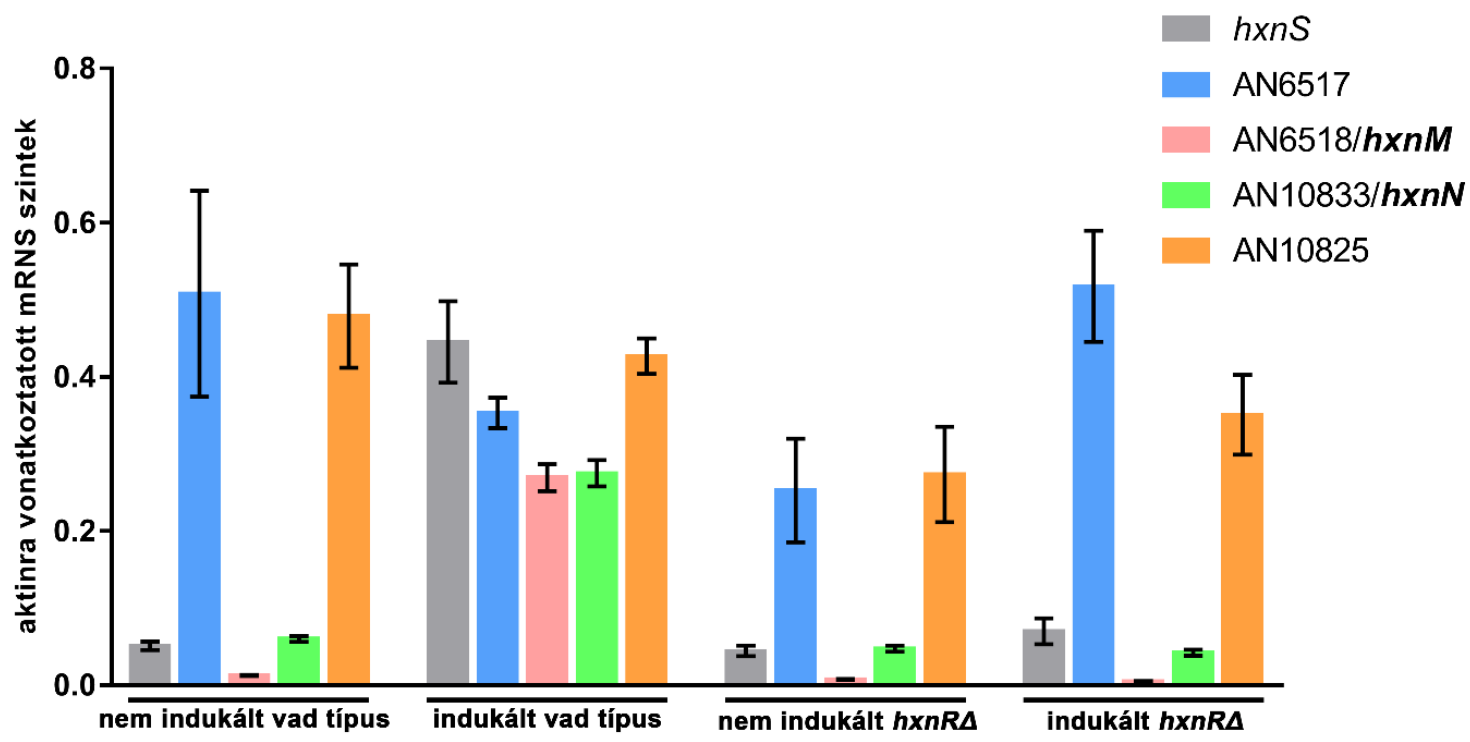

9. ábra: A $h x n M$ és $h x n N$ gének, valamint a velük szomszédos gének kifejeződésének vizsgálata RT-qPCRrel. 
Az AN6518 (hxnM) és AN10833 ( $h x n N)$ gének, valamint a velük szomszédos AN6517 és AN10825 gének mRNS szintje vad típusú és $h x n R \Delta$ ( $h x n R$ deléciós) törzsekben nem indukált és indukált (1 mM 6-NA-val végzett indukció) körülmények között. A nem indukált körülmény 10 óra acetamidon történő tenyésztés volt. Az

indukált körülmény esetén 8 óra acetamidon történő tenyésztést követően $1 \mathrm{mM}$ 6-NA-val egészítettük ki a tápoldatot és további 2 órán át inkubáltunk. Háztartási génként a gamma-aktin génjét ( $a c n A)$, kontrollként pedig a hxnS gént használtuk. Az RT-qPCR eredményeket a „relative standard curve” elemzési módszerrel kaptuk. Az ábrán három biológiai ismétlés szórási eredményeit tüntettük fel.

A transzkriptum vizsgálat alapján azonosítottunk egy, a NA lebontásában részt vevő hxnM és hxnN géneket tartalmazó harmadik klasztert az I. kromoszómán, amelyet NDC3-nak neveztünk el (10. ábra).

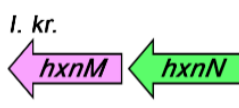

NDC3

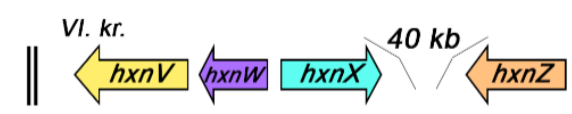

NDC2
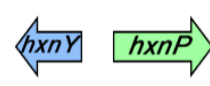

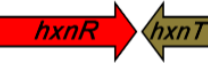

NDC1

10. ábra: A NA lebontásában részt vevő gének sematikus ábrája.

A két függőleges vonal kromoszómahatárokat jelöl. A színes nyilak az egyes géneket és orientációjukat jelölik. I. kr.: I. kromoszóma, VI. kr.: VI. kromoszóma. A tört vonal az NDC1 és NDC2 között 40 kb genomi távolságot jelöl.

\subsection{A hxnV gén cDNS szekvenciájának meghatározása}

Habár az AspGD adatbázisban gépi annotációval megállapítják az exon-intron határokat és az alapján prediktálják egy gén által kódolt fehérje szekvenciáját, korábbi tapasztalataink alapján előfordul, hogy az adatbank tévesen prediktál intronokat vagy intron pozíciókat. Annak érdekében, hogy in silico analízist végezhessünk az NDC2 és NDC3 klaszterek hxn géntermékein, elengedhetetlen volt, hogy cDNS szekvenálással megállapítsuk a hxn gének exon szekvenciáját és az azokról készített AS szekvenciákkal dolgozzunk tovább a fehérjefunkció elemzések során. A cDNS szekvenálások során (az indítószekvenciákat a 4. mellékletben listáztuk) a $h x n X, h x n W, h x n M$ és $h x n N$ gének cDNS szekvenciája azonosnak bizonyult az AspGD adatbázisban található adatokkal, azonban eltérést találtunk a $h x n V$ gén esetén (11. ábra).

A $h x n V$ szekvenciájának vizsgálata során megfigyeltük, hogy az adatbázisban exonként van prediktálva egy 53 nt hosszúságú szakasz (az 1033. nt-tól az 1085. nt-ig tartó szekvencia), mely a cDNS szekvenálás alapján egy intront kódol. Megállapítottuk azt is, hogy az adatbázis 1131. nt-ja utáni, intronként prediktált szekvencia a cDNS szekvenálás alapján egy $32 \mathrm{nt}$ hosszúságú exon szekvencia (11. ábra „A” panel). Továbbá kiderítettük, hogy az adatbázisban a 2179. nt-tól a 2442. nt-ig tartó intron szekvencia nem létezik, és a $h x n V$ gén valójában a genomi 2266. nt-nál véget ér (11. ábra „B” panel). 


\section{$A$} $\begin{array}{ll}\text { adatbázis cDNS } & 957 \text { CGGAAACTACGTCGTTGGGCAGCGCGTGGCGAGACATTTCTCTGATCCTGATTACCAGAT } \\ \text { saját cDNS } & 957 \text { CGGAAACTACGTCGTTGGGCAGCGCGTGGCGAGACATTTCTCTGATCCTGATTACCAGAT }\end{array}$ $* * * * * * * * * * * * * * * * * * * * * * * * * * * * * * * * * * * * * * * * * * * * * * * * * * * * * * * * * * * *$

adatbázis cDNS 1017 CTTCATTGCTGGCGATGCACGTCCCCTTCCGTCTGACCTCTTTCTCAGTTTGTCTAACAG 1017 CTTCATTGCTGGCGATGCACGTCCCCTTCCGTCTGACCTCTTTCTCAGTTTGTCTAACAG $* * * * * * * * * * * * * * * *$

adatbázis cDNS 1077 GTTCTTTAGGCCGGTCACTGCCACTCTGCGCTCGCCGCCCAAGGTGCAAACACCA-D saját cDNS 1033 - GCCGGTCACTGCCACTCTGCGCTCGCCGCCCAAGGTGCAAACACCA GTATG **********************************************

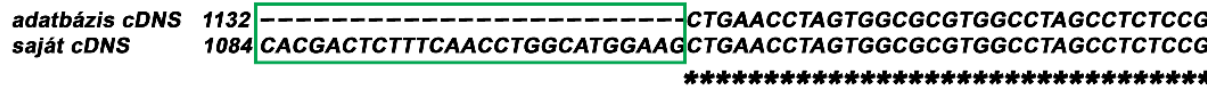

adatbázis cDNS 1165 TCTCTGCTGGAGACTTACGAAACTGAGCGGCGCAAGATCGCAAACGACCTCATTGCCTTT saját cDNS 1144 TCTCTGCTGGAGACTTACGAAACTGAGCGGCGCAAGATCGCAAACGACCTCATTGCCTTT $\star * * * * * * * * * * * * * * * * * * * * * * * * * * * * * * * * * * * * * * * * * * * * * * * * * * * * * * * * * * *$

adatbázis cDNS 1225 GACGCCGAGCACTGTGCTGCATTTGAGGCAGGCGAAGCCGCCCTTGCCAGGAACTTTGAT saját cDNS 1204 GACGCCGAGCACTGTGCTGCATTTGAGGCAGGCGAAGCCGCCCTTGCCAGGAACTTTGAT $* * * * * * * * * * * * * * * * * * * * * * * * * * * * * * * * * * * * * * * * * * * * * * * * * * * * * * * * * * * *$ $B$

adatbázis cDNS 1785 TGTGGAAGGGTGTATTGAGAAGTGGGTTGGGGAGCTGCCAGAAACACAGGCTGGGATTGT saját cDNS 1764 TGTGGAAGGGTGTATTGAGAAGTGGGTTGGGGAGCTGCCAGAAACACAGGCTGGGATTGT adatbázis genomi 2101 TGTGGAAGGGTGTATTGAGAAGTGGGTTGGGGAGCTGCCAGAAACACAGGCTGGGATTGT

adatbázis cDNS 1845 GCTAGTGAGGCCAGACGG saját cDNS 1824 GCTAGTGAGGCCAGACGGGTATGTTGC adatbázis genomi 2161 GCTAGTGAGGCCAGACGGGTATGTTGCGGGCCTTAGGGTTTGGGATCTCGGTGAGGGTGA $* * * * * * * * * * * * * * * * * *$

adatbázis cDNS

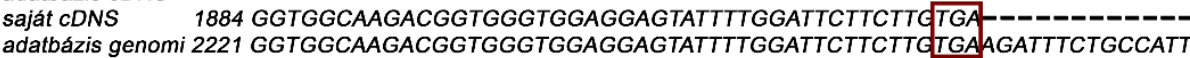
(1)
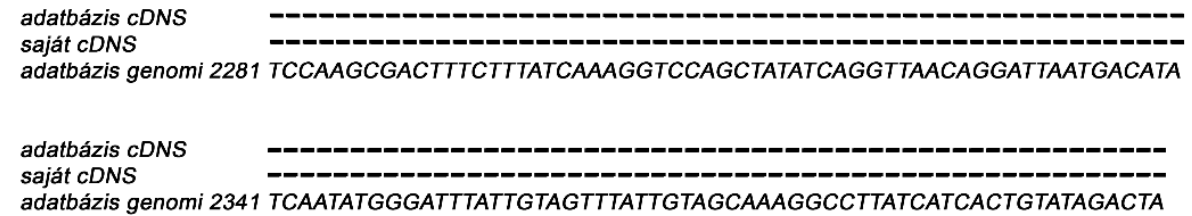

11. ábra: A hxnV adatbázisból letöltött exon szekvenciájának összehasonlítása az általunk cDNS szekvenálással generált $h x n V$ szekvenciával és a genom szekvenciával.

A panel: Az adatbázistól eltérő exont és intront tartalmazó szekvenciarészlet. Csillaggal jelöltük az egyező bázisokat, piros kerettel az adatbázisban exonnak vélt szekvencia látható, amely valójában intron, zöld kerettel pedig az exon szekvencia van jelölve, amely az adatbázis alapján egy intron. B panel: A hxnV szekvencia 3' vége. Csillaggal jelöltük az egyező nukleotidokat, bordó kerettel pedig a $h x n V$ STOP kodonját.

A cDNS szekvenálás alapján megállapított exon-intron határokat a 2. Táblázat mutatja. 
2. Táblázat: A $h x n V$ gén exon-intron határai.

\begin{tabular}{|l|l|}
\hline Exon & $1-116 \mathrm{nt}$ \\
\hline Intron & $117-169 \mathrm{nt}$ \\
\hline Exon & $170-344 \mathrm{nt}$ \\
\hline Intron & $345-441 \mathrm{nt}$ \\
\hline Exon & $442-805 \mathrm{nt}$ \\
\hline Intron & $806-866 \mathrm{nt}$ \\
\hline Exon & $867-1094 \mathrm{nt}$ \\
\hline Intron & $1095-1167 \mathrm{nt}$ \\
\hline Exon & $1168-1250 \mathrm{nt}$ \\
\hline Intron & $1251-1303 \mathrm{nt}$ \\
\hline Exon & $1304-2200 \mathrm{nt}$ \\
\hline
\end{tabular}

Eredményeink alapján az adatbázis szerinti 629 AS hosszúságú fehérje helyett egy 600 AS-ból álló, az adatbázisban leírtaktól eltérő AS összetételü fehérje íródik át. A cDNS szekvenálás alapján a HxnV fehérje AS szekvenciája a következő:

MARSADHDQGFANIDTDAAPAGETTVVIVGAGPSGLMLAVNLVRLGTPIVLLDDRPDKTSTGKADGIQPKTIETL KQLRLADKLLRDGARIYDISFWDSTESHPLRRKGRQTHYPDHLVGASDPY I LLVHQGMLEDVLIDDLAERGVTVT RNSSFLSCSRNPSKKLDVVYEDQSTGTKKVIQTEYLVGCDGARSSVREFI PDAQLEGEMTNASWGVLDGVIETDF PDLWSKVAVRTHTVGSLLWI PRERGMTRLYVELSATAGERIDKAKATPQYVMERAKEAMKPFS LEWKS IEWFGNY VVGQRVARHFSDPDYQIFIAGDAGHCHSALAAQGANTSMHDSFNLAWKLNLVARGLASPSLLETYETERRKIAND LIAFDAEHCAAFEAGEAALARNFDENIRFISGVGAEYDAS I LTQTKVSDAGKGSRRLKPGALLIPAKATRYIDAN PVDIQLDVPLLGQFRLYFLI PNVSAAKEKGFLEVVCQI LSSPTS I LAISAEKAKESYTSRSRGWSATDAYQVPER YTTVSEIITLSLISGSKREVFEIADLPLALQKSRWTVYLDDVEGCIEKWVGELPETQAGIVLVRPDGNYPRTPNA 


\subsection{Az NDC2 és NDC3 géntermékek in silico jellemzése}

A $h x n V, h x n X, h x n W, h x n M$ és $h x n N$ gének felfedezését követően in silico funkcióelemző vizsgálatokat végeztünk annak érdekében, hogy információt nyerjünk a lebontási útvonalban részt vevő gének útvonalban betöltött lehetséges szerepéről.

\subsubsection{A HxnV jellemzése}

A hxnV gén (AN11187, 2266 nt) egy 600 AS hosszúságú fehérjét kódol, mely a 49. és a 64. AS között rendelkezik egy transzmembrán doménnel, melyet egy UbiH FAD-függö oxidoreduktáz domén (COG0654) és egy PHOX-C domén (cd02979) követ. Az utóbbi domén FAD-függő fenol hidroxilázokra jellemző, melyek C-terminálisukon a dimerizációban részt vevő TRX-fold doménnel rendelkeznek. A PHOX enzimek a fenol és egyszerü fenol származékok orto pozícióban történő hidroxilálását katalizálják, mely során NADPH-t és oxigént használnak fel. A HxnV fehérje legközelebbi szerkezeti homológja a Trichosporon cutaneum fenol 2-monooxigenáza (fenol hidroxiláz, PDB: 1pn0; 100\% megbízhatóság, 96\% lefedettség és 33\% azonosság). A T. cutaneum fenol 2-monooxigenáz Tyr289 (Tyr255 a HxnV fehérjében), Ile279 (Ile245 a HxnV fehérjében) és Val114 (Leu128 a HxnV fehérjében) AS-ai hidrofób kölcsönhatást létesítenek a fenolgyürü 2. és 6. szénatomja között, míg a Tyr289 (Tyr255 a HxnV fehérjében) és Asp54 (Asp65 a HxnV fehérjében) AS-ak hidrogén kötést alakítanak ki a szubsztrát molekula hidroxil csoportjával (12. ábra) (Enroth, 2003). Ezen kívül a Tyr289 (Tyr255 a HxnV fehérjében) hidrogén kötésen keresztül képes kapcsolódni a FAD kofaktorhoz is (Enroth, 2003). A T. cutaneum fenol 2-monooxigenázának aktív centrumát alkotó AS-ak és a HxnV megfelelő AS-ainak jelentős azonossága alapján ésszerü feltételezni, hogy a HxnV szubsztrátja a piridingyürü egy hidroxilált származéka. A fenol 2-monooxigenáz és annak fenol szubsztrátjával analógiát feltételezve lehetséges, hogy a HxnV szubsztrátja a heterociklikus piridingyürün olyan szénatomon hidroxilált, amelynek szomszédjai szintén szénatomok. Ezek a feltételek a 2,5-DP molekula 5. szénatomja esetében teljesülnek. Elméletileg a hidroxilált 5. szénatomtól orto pozícióban történő hidroxiláció 2,4,5trihidroxipiridint, vagy 2,3,6-trihidroxipiridint eredményez. P. putida esetében a lebontási útvonalban a 2,5-DP-t egy, az extradiol gyürühasító dioxigenázok egy új családjának alapító tagja, a NicX használja szubsztrátként, és a 2,5-DP molekulát az 5. és 6. szénatom között hasítva N-formil-maleinsavamidot képez. A $\mathrm{HxnV}$ legközelebbi $P$. putida homológja a phidroxibenzoát hidroxiláz (PDB: 6d11) 23\% azonossággal (53\% lefedettség). Mindezek értelmében az $A$. nidulans lebontási útvonala a 2,5-DP-t követően eltér a $P$. putida útvonalától, és a 2,5-DP gyürüjének felnyitása helyett a 2,5-DP hidroxilálása feltételezhető. 


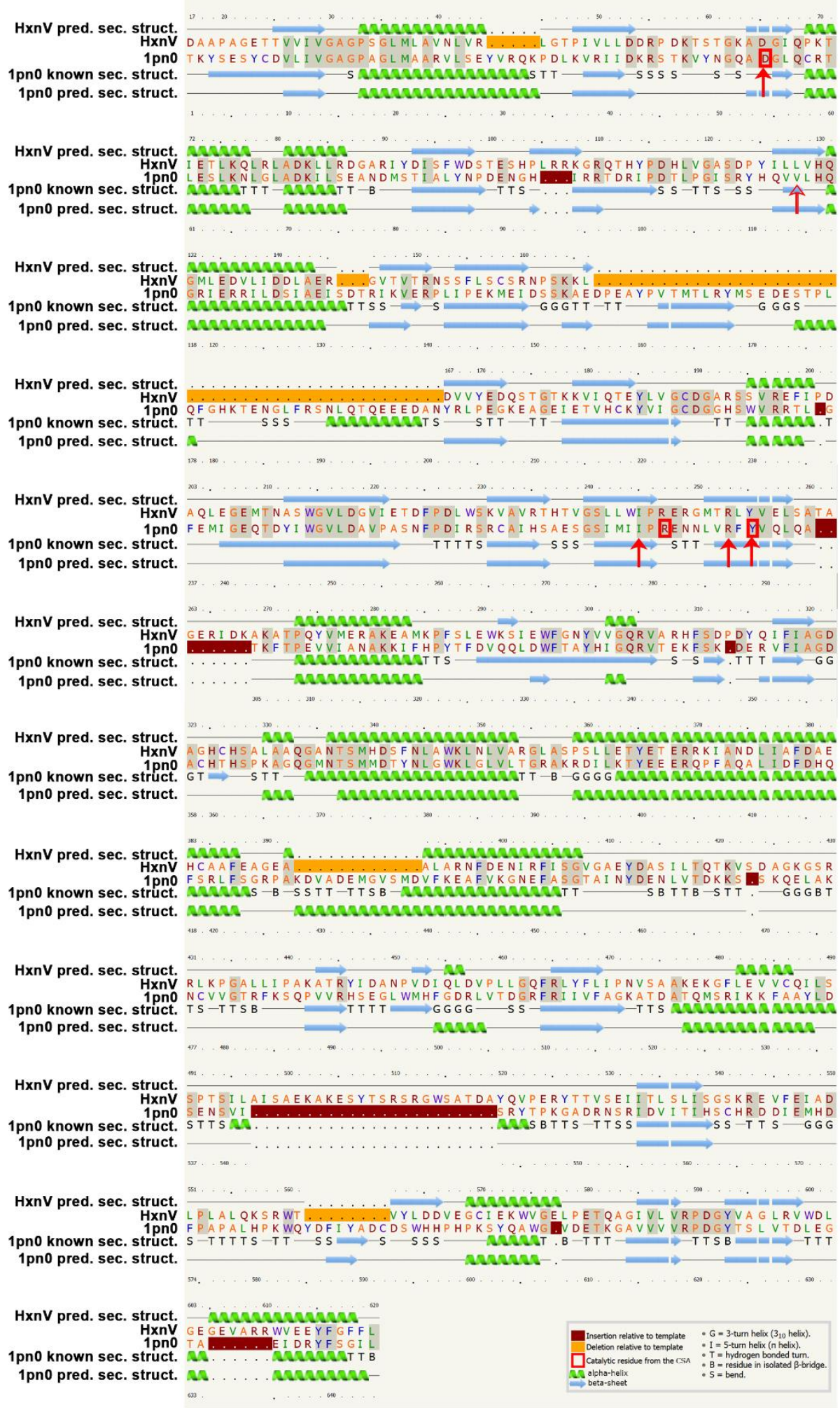

12. ábra: A HxnV szerkezeti hasonlóságot mutat a Trichosporon cutaneum fenol 2-monooxigenázával (fenol hidroxiláz).

A HxnV prediktált másodlagos szerkezetének és a T. cutaneum fenol-2-monooxigenáz (PDB: 1pn0) ismert (known sec. struct) és prediktált (pred. sec. struct.) másodlagos szerkezetének összehasonlítása Phyre2 analízis

(Kelley és mtsai., 2015) segítségével. A piros nyilak a fenol-kötésben részt vevő AS-akat jelölik. 


\subsubsection{A HxnX jellemzése}

A 461 AS hosszúságú fehérjét kódoló $h x n X$ gén (AN9161, 1582 nt) génterméke UbiH FAD-függő oxidoreduktáz domént (COG0654) tartalmaz, amely NADB_Rossmann szupercsalád (cl21454), PRK06847 szupercsalád (c127550) és FAD_kötő_3 szupercsalád (pfam01494, c127552) doménekre jellemző tulajdonságokkal rendelkezik és nem specifikus kapcsolatban áll a Szalicilát 1-monooxigenáz családdal (TIGR03219). A fehérje legközelebbi szerkezeti homológja (100\% megbízhatóság, 32\% azonosság és 83\% lefedettség) a HxnX fehérjével valószínűleg azonos funkcióval bíró 6-hidroxinikotinsav 3-monooxigenáz (NCBI: WP_010954763.1, PDB: 5eow), a P. putida KT2440 NicC fehérjéje (Hicks és mtsai., 2016). A NicC-ről (Jimenez és mtsai., 2008), valamint az ezzel homológ $P$. fluorescens TN5 fehérjéről (Nakano és mtsai., 1999) bebizonyították, hogy membrán-kapcsolt monooxigenáz flavoenzimek dekarboxiláz funkcióval, melyek NADH-t, FAD-ot és $\mathrm{O}_{2}$-t használnak fel a 6NA 2,5-DP-né történő hidroxilálása során (Nakano és mtsai., 1999). A NicC His211 és Tyr215 AS-ai (melyek HxnX megfelelői a His232 és Tyr236) közvetlenül kölcsönhatásba lépnek a 6NA szubsztráttal és hat további AS-val együtt (melyek HxnX-ben nem mutatnak konzerváltságot) részt vesznek az aktív centrum kialakításában (Hicks és mtsai., 2016) (13. ábra). A 6-NA-kötő AS-ak konzerváltsága a HxnX-ben arra utalhat, hogy a NicC-hez hasonlóan a HxnX is elfogadja a 6-NA-t szubsztrátként és feltehetően katalizálja annak dekarboxilálását és hidroxilálását.

A HxnX C-terminálisán található peroxiszómás lokalizációs szignál (SRL), valamint az in silico vizsgálatok során kapott normál megbízhatóságú $(0,36)$ és magas $(76,7 \%)$ valószínüségü peroxiszómás lokalizáció predikció (YLoc-HighRes Fungi) alapján a HxnX feltételezhetően a peroxiszómákban lokalizálódik. Ezen túlmenően, a 20-35 AS-ból álló transzmembrán domén alapján a HxnX, hasonlóan a $P$. fluorescens esetén tapasztaltakkal (Nakano és mtsai., 1999), membránhoz kapcsolt fehérje. A HxnX legközelebbi ismert gomba homológja a Candida parapsilosis CDC317 4-hidroxibenzoát 1-hidroxiláza, az MNX1 (37 \% azonosság, CGD: CPAR2_102790, GeneBank: CCE40241.1, (Holesova és mtsai., 2011). Hasonlóságot feltételezve a $P$. putida NicC és a $C$. parapsilosis MNX1 fehérjékkel (a benzolgyürüt piridingyürüre cserélve), a HxnX valószínűleg dekarboxilálja a 6-NA-at, majd a képződő 2-hidroxi-nikotinsav piridingyürüjének 5-hidroxilálása révén 2,5-DP keletkezik. 
A

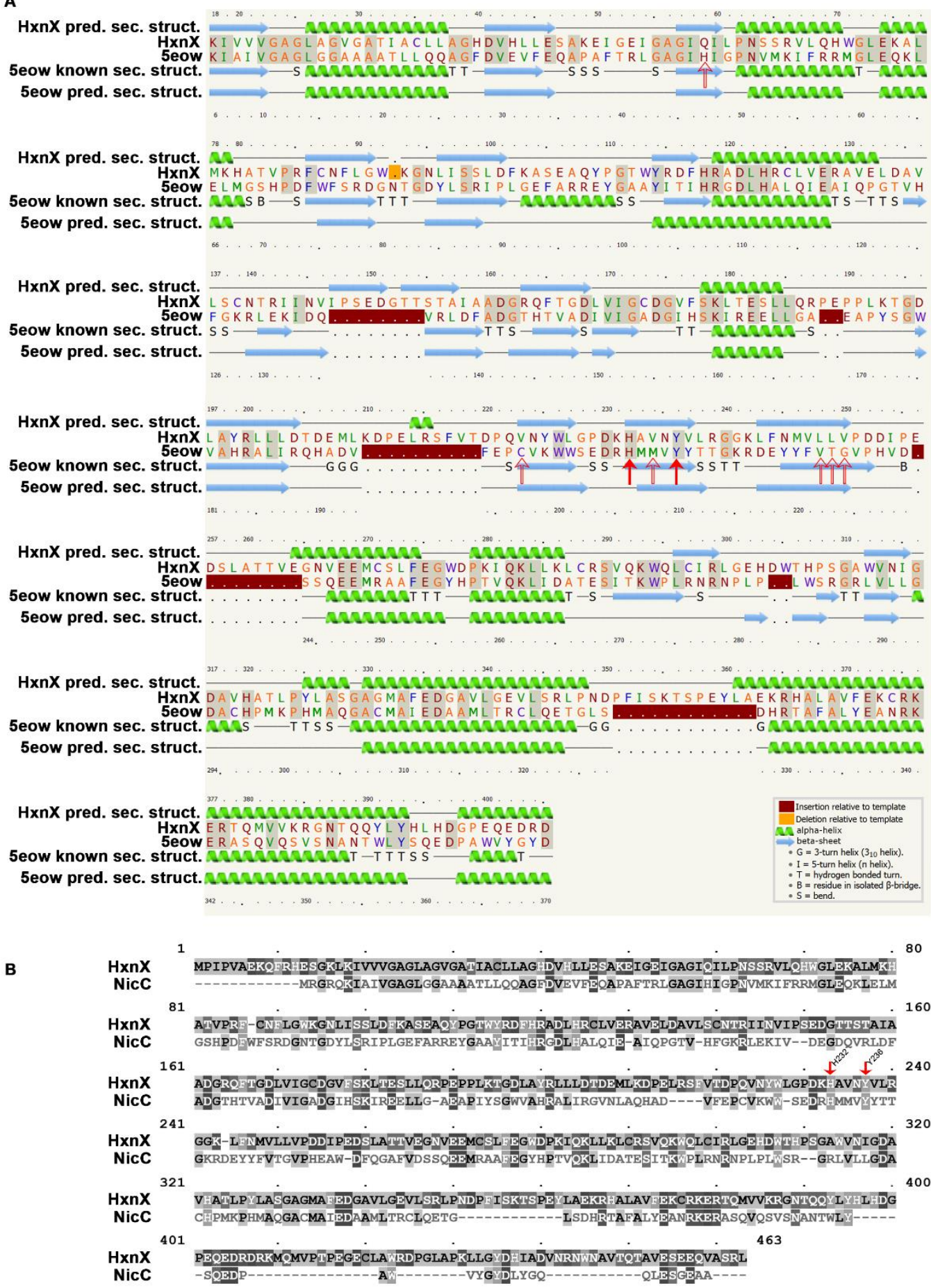

13. ábra: A HxnX szerkezeti hasonlóságot mutat a $P$. putida 6-hidroxinikotinsav 3-monooxigenázával, a NicC-vel.

A panel: A HxnX valószínűsíthető másodlagos szerkezetének (pred. sec. struct) és a $P$. putida NicC (PDB: 5eow) ismert (known sec. struct) és valószínüsíthető másodlagos szerkezetének összehasonlítása Phyre2 analízis (Kelley és mtsai., 2015) segítségével. A teli piros nyilak a szubsztrát-kötő AS-akat, míg az üreges piros nyilak a további aktív centrum képző AS-akat jelölik, melyek a NicC aktív centrumába térképeződtek. B panel: A HxnX és a $P$. putida NicC (NP_746074) (Jimenez és mtsai., 2008) szekvenciájának összehasonlítása. A szekvenciák illesztése Muscle programmal történt, majd a kapott eredményeket MView programmal jelenítettük meg. A piros nyilak a HxnX 6-NA szubsztrát-kötő AS-ait jelölik. 


\subsubsection{A HxnW jellemzése}

A hxnW génről (AN11172, 861 nt) egy mindössze 254 AS hosszúságú fehérje íródik át, amely a rövid láncú dehidrogenáz/reduktáz (SDR) család MDH-szerü_SDR_c típusú (cd05352) fehérjéihez hasonló jellegzetességekkel rendelkezik. A HxnW rendelkezik egy szerkezetileg konzervált NADB_Rossmann-fold doménnel, melyben Ser (S146) és Asn (N116) AS-ak, valamint egy konzervált $\mathrm{Y}(\mathrm{X})_{3} \mathrm{~K}$ motívumot formáló Tyr (Y161) és Lys (K165) alkotja a konzervált katalitikus tetrádot (Kavanagh és mtsai., 2008) (14. ábra). Ezen kívül, a HxnW fehérjében megtalálható egy gomba ketoreduktázokra jellemző $\mathrm{NAD}(\mathrm{P})$-kötő $\mathrm{TG}(\mathrm{X})_{3} \mathrm{GXG}$ motívum is (14-21 AS). A különböző MDH-szerü_SDR_c típusú fehérjék esetén a C-terminális régió a specifikus szubsztrát kötésnek megfelelően variábilis. Az SDR családba tartozó enzimek a reakciók széles körét képesek katalizálni, többek között izomerizációt, dekarboxilációt, epimerizációt, $\mathrm{C}=\mathrm{N}$ kötés redukcióját, dehidratáz aktivitást, dehalogenizációt, az enoil-KoA redukcióját és karbonil-alkohol oxidoredukcióját (Kavanagh és mtsai., 2008). A HxnW ortológja Saccharomyces cerevisiae S288C Sps19p fehérjéje (30\% azonosság 96\% lefedettséggel), egy NADPH-függő peroxiszómális 2,4-dienoil-KoA reduktáz, mely homodimer formában müködik (Gurvitz és mtsai., 1997). A HxnW legközelebbi jellemzett szerkezeti homológja a Gluconobacter oxydans poliol dehidrogenáza, a Gox2181 (PDB: 3awd; 100\% megbízhatóság, 98\% lefedettség) (14. ábra), mely homotetramert képezve NAD(H)függő módon látja el funkcióját (Liu és mtsai., 2011). Az SDR fehérjék szerkezeti-funkcionális modelleinek hiánya miatt a HxnW funkciójára nem tudunk következtetni, azonban azt feltételezzük, hogy vagy ketoreduktázként működik, vagy dekarboxilációt végez a NA lebontás valamely aromás köztestermékén. 


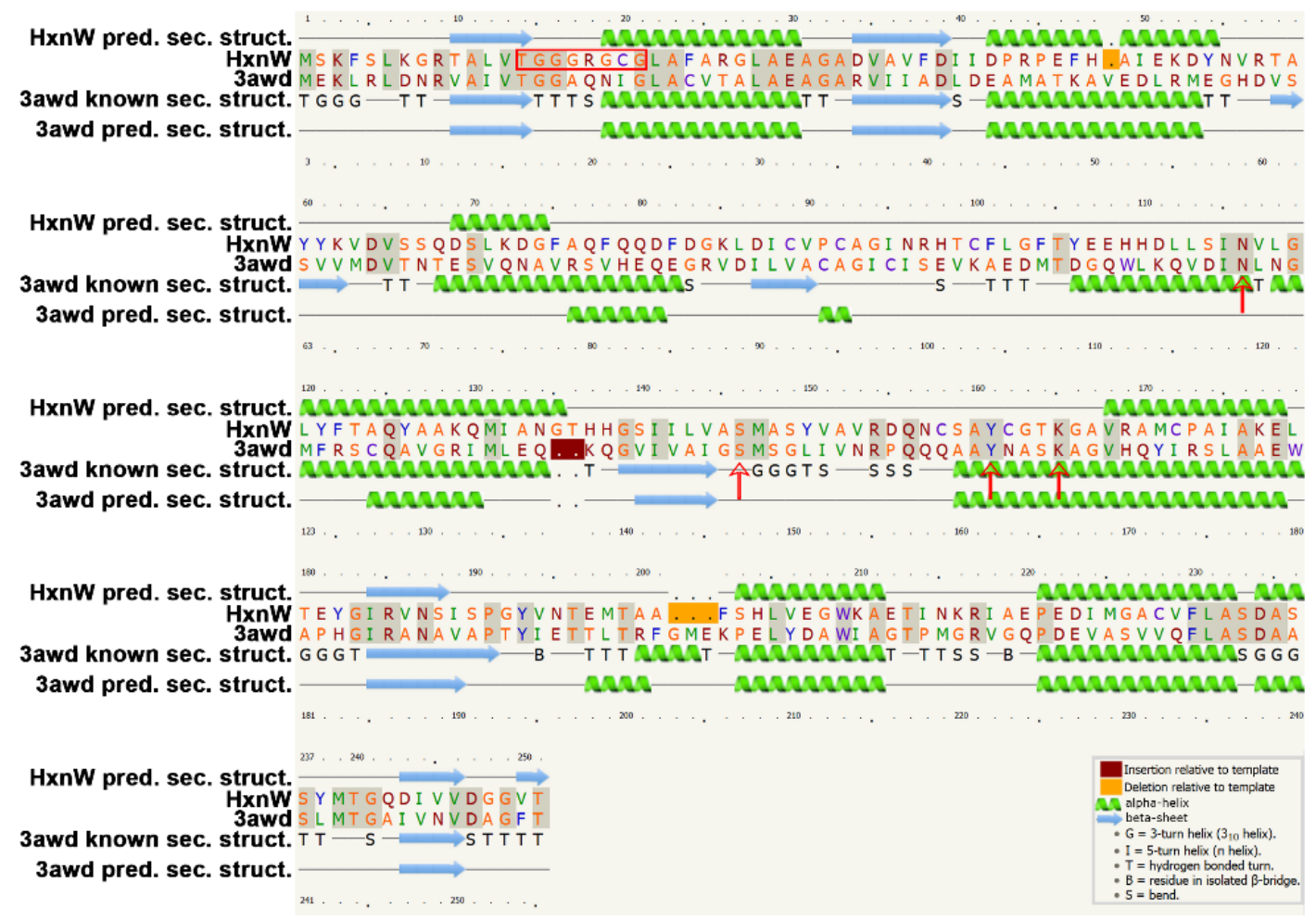

14. ábra: A HxnW szerkezeti hasonlóságot mutat a Gluconobacter oxydans Gox2181 poliol dehidrogenázával.

A HxnW valószínüsíthető (pred. sec. struct) másodlagos szerkezetének és a G. oxydans Gox2181 (PDB: 3 awd) ismert (known sec. struct) és valószínüsíthető másodlagos szerkezetének összehasonlítása Phyre2 analízis (Kelley és mtsai., 2015) segítségével. A bekeretezett AS-ak a gomba ketoreduktázokra jellemző TG(X)3GXG

NAD(P)-kötő motívumot jelölik. A piros nyilak a NADB_Rossmann-fold domén konzervált katalitikus tetrádját jelölik.

\subsubsection{A HxnM jellemzése}

A hxnM gén (AN6518, 1095 nt) egy 307 AS hosszúságú fehérjét kódol, melyet egy CE4_HpPgdA_szerü domén (cd10938) alkot, amelyet a Helicobacter pylori peptidoglükán deacetiláza (HpPgdA; PDB: 3qbu) példáz. A HpPgdA 65\% azonossággal a HxnM legközelebbi szerkezeti homológja (93\% lefedettség és 100\% megbízhatóság) (15. ábra). A HpPgdA (HP0310) katalitikus doménje tetramert képez és aktív helyén Zn iont hordoz (Shaik és mtsai, 2011). A HpPgdA fehérje Zn ionokat koordináló AS-ainak (His86/His90/Asp14), a vízmolekulákat kötő katalitikus AS-aknak (His247/Asp12/Asp14) és egyéb katalitikus ASaknak (Asp199/Asp200/Val124) (Shaik és mtsai., 2011, Bhattacharjee és mtsai., 2017) megfelelö AS-ak konzerváltak a HxnM fehérjében (His87/His91/Asp15, His248/Asp13/Asp15 és Asp200/Asp201/Val125 AS-aknak felelnek meg HxnM fehérjében) (15. ábra). A HpPgdA deacetilálja a peptidoglükánokat az N-acetilglükozaminok és az N-acetilmuraminsavak Nkapcsolt acetil csoportjaiban a C-N kötések hasításán keresztül (Bhattacharjee és mtsai., 2017). 
A HxnM 74,3\% azonosságot mutatott (100\% lefedettség) egy Candida bondii-ból származó enzimmel (OWB68015), melyet C-N (de nem peptid) kötés hidrolázként annotáltak (enzim család: EC 3.5.99, GO term: 0016810). A P. putida fehérjéken végzett BlastP keresés során egy ciklikus-imid-hidroláz (AAY98498) adott nagyfokú (64,2\%) azonosságot a HxnM fehérjével (95,4 \% lefedettséggel) (Shi és mtsai., 2007), míg a P. putida NA lebontási útvonalának gyürühasító enzime, a NicX (az extradiol gyürühasító dioxigenázok (c119596) egy új családjának alapító tagja, mely az 5. és 6. szénatom között történő gyürühasítás katalíziséhez $\mathrm{Fe}(\mathrm{II})$ iont és molekuláris oxigént használ) mindössze 13,8\% azonosságot (91,9\% lefedettség) mutatott. Az alapján, hogy a NicX és a HxnM különbözö enzimcsaládok tagjai, arra következtethetünk, hogy a NA lebontása a különböző gombákban konvergens evolúció során alakult ki.

A HxnM és ciklikus imidázok (mind gomba, mind bakteriális) homológiája, valamint a C-N kötést hasító hidrolázok (például a HpPgdA peptidoglükán deacetiláz) aktív helyén található Zn ion koordináló és vízmolekula kötő AS-ak nagyfokú hasonlósága alapján feltételezhető, hogy a HxnM a NA lebontás egy telített piridingyürüvel rendelkező köztestermékét hasítja fel egy szén és egy nitrogén molekula között. 


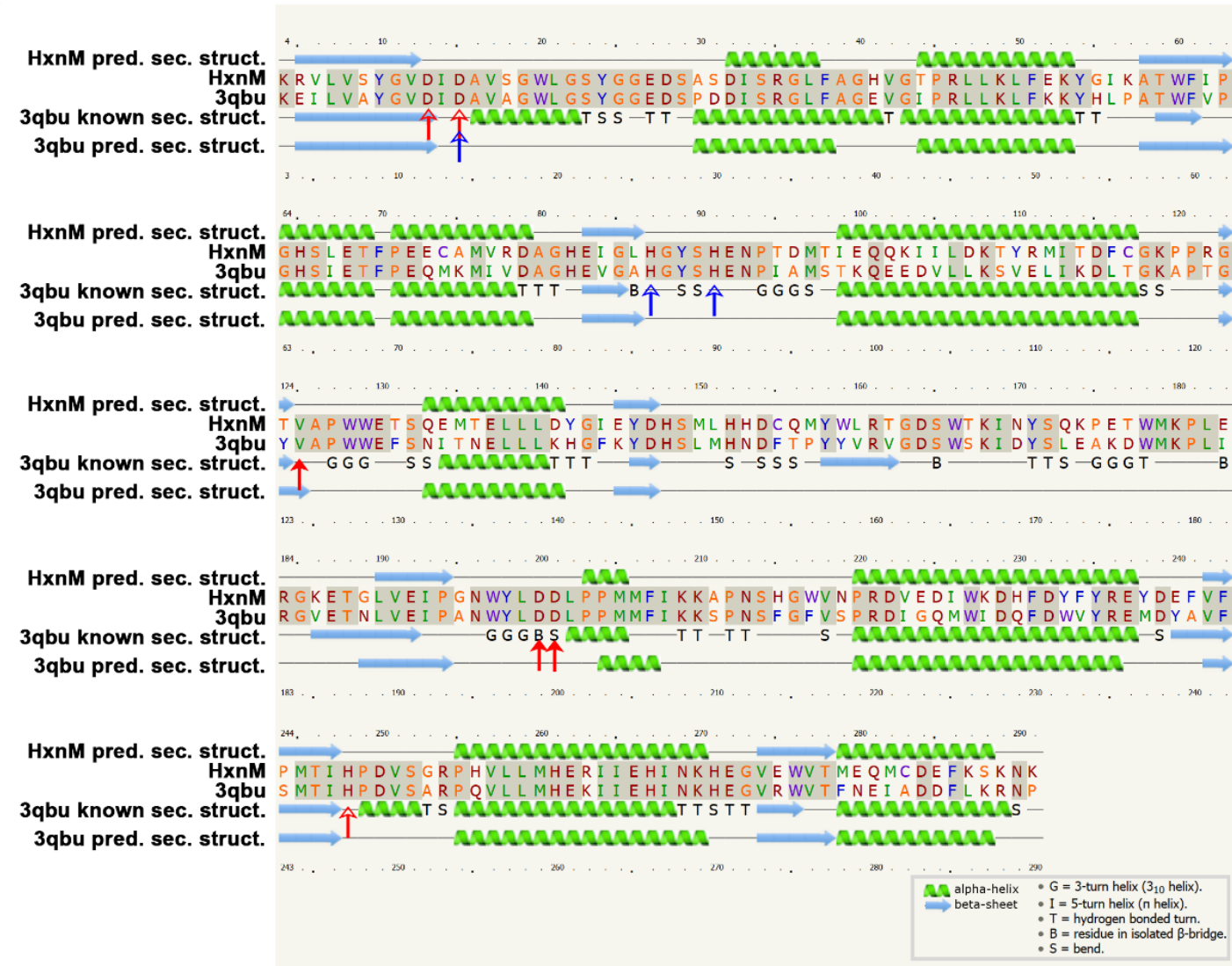

B

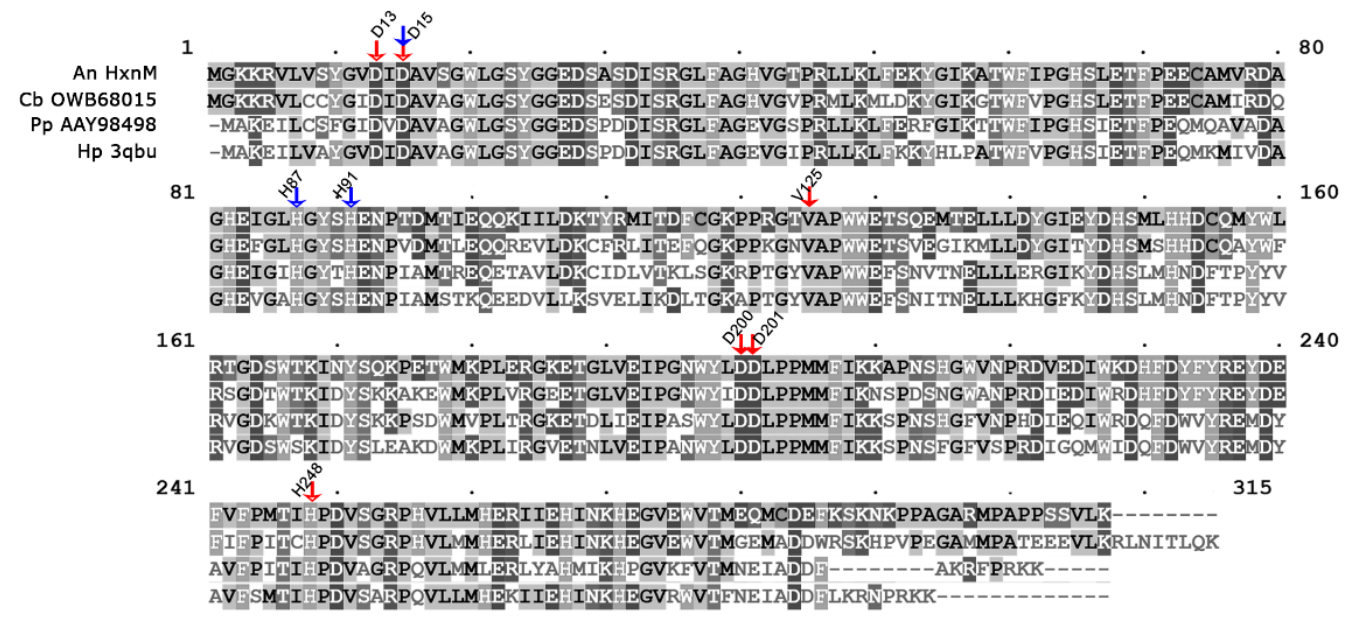

15. ábra: A HxnM szerkezeti hasonlóságot mutat a Helicobacter pylori HpPgdA peptidoglükán deacetilázával.

A panel: A HxnM valószínüsíthető (pred. sec. struct) másodlagos szerkezetének és a H. pylori HpPgdA (PDB: 3qbu) ismert (known sec. struct) és valószínüsíthető másodlagos szerkezetének összehasonlítása Phyre2 analízis (Kelley és mtsai., 2015) segítségével. Az üreges piros nyilak a katalitikus vízkötő AS-akat, a teli piros nyilak az egyéb katalitikus helyek AS-ait, a kék nyilak pedig a HpPgdA Zn ion koordináló AS-ait jelölik (Shaik és mtsai.,

2011, Bhattacharjee és mtsai., 2017). B panel: A HxnM szekvenciájának összehasonlítása a Candida bondii hidrolázával (OWB68015), Pseudomonas putida ciklikus imid hidrolázával (AAY98498) és a H. pylori HpPgdA

fehérjéjével. A szekvenciák illesztése Muscle programmal történt, majd a kapott eredményeket MView programmal jelenítettük meg. A nyilak a HpPgdA katalitikus helyének AS-ait és a Zn ion koordináló AS-ait jelölik, melyek megfelelnek a HxnM AS-ainak. 


\subsubsection{A HxnN jellemzése}

Az 543 AS hosszúságú fehérjét kódoló hxnN gén (AN10833, 1851nt) génterméke egy GatA típusú (Asp-tRNSAsn/Glu-tRNSGln amidotranszferáz A alegység, vagy kapcsolódó amidáz domén) amidáz doménből (pfam01425) áll, és a 463-478 AS régiója transzmembrán jellegzetességeket mutat. A HxnN S. cerevisiae (AMD2) és Schizosaccharomyces pombe (Fah1) ortológjai feltehetőleg amidázok. A HxnN legközelebbi szerkezeti homológja a Rattus norvegicus zsírsavamid-hidroláz 1 (FAAH) fehérjéje (PDB: 2vya; 100\% megbízhatóság, 32\% azonosság, 98\% lefedettség) (16. ábra). Az amid csoport hidrolízisében szerepet játszó Ser-SerLys katalitikus triádnak megfelelő AS-ak (Ser217/Ser241/Lys142 a FAAH fehérjében), a triádot támogató Ser AS (Ser218 a FAAH fehérjében), valamint az oxianion üreget képző ASak (Ile238/Gly239/Gly240/Ser241 a FAAH fehérjében; (Shin és mtsai., 2002, Mileni és mtsai., 2008) a HxnN esetében konzerváltak (Ser208/Ser232/Lys133, Ser209 és Ile229/Gly230/Gly231/Ser232) (16. ábra). Ezek alapján feltételezzük, hogy a HxnN lehasítja egy felnyílt gyürüs szerkezetü köztestermék amid csoportját, amely ezt követően nitrogénforrásként hasznosulhat. A növekedési tesztek értelmében azonban a visszamaradó szénvegyület nem hasznosul szénforrásként. 


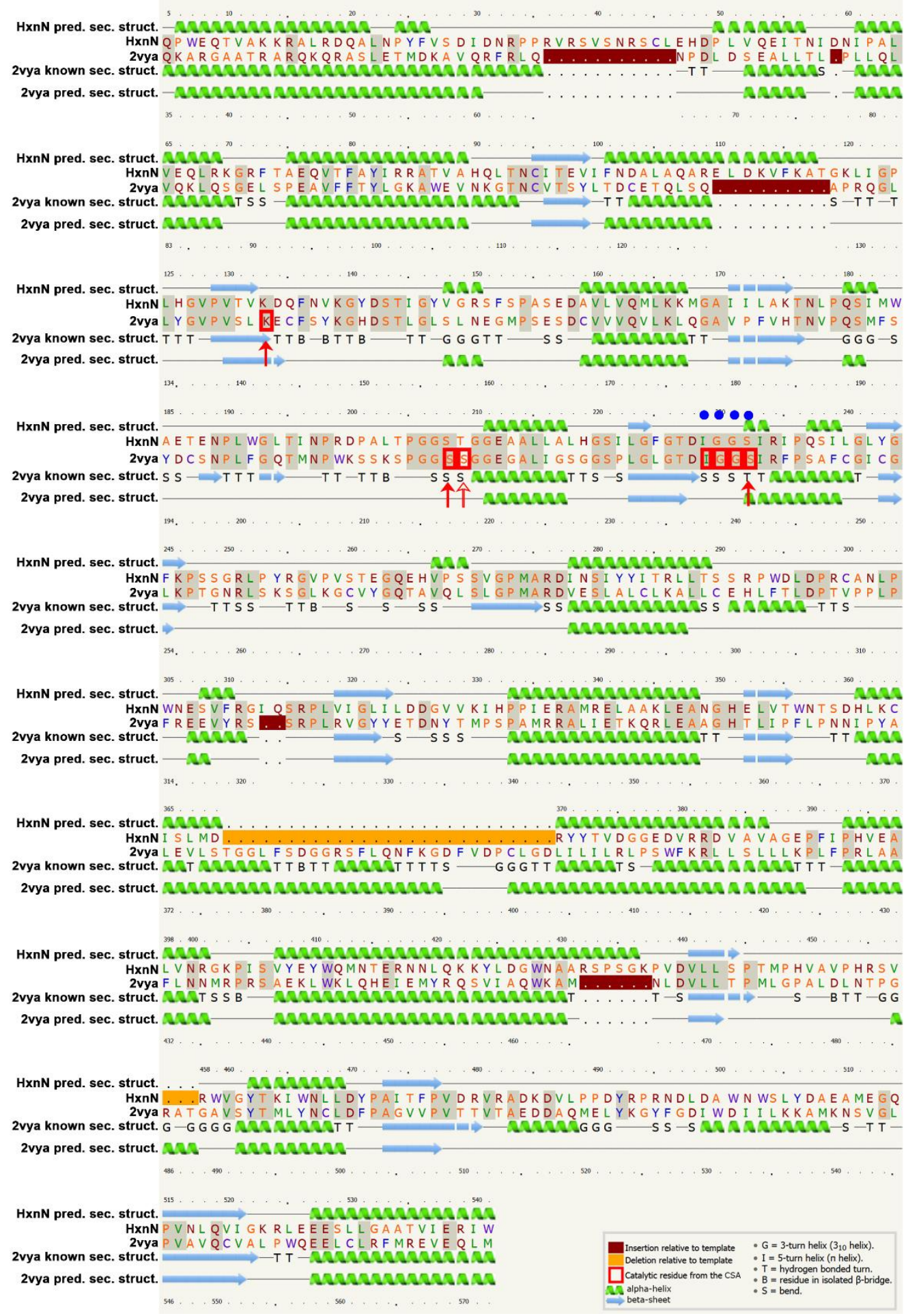

16. ábra: A HxnN szerkezeti hasonlóságot mutat a Rattus norvegicus zsírsavamid-hidroláz 1 (FAAH) fehérjéjével.

A HxnN valószínüsíthetö (pred. sec. struct) másodlagos szerkezetének és a $R$. norvegicus FAAH (PDB: 2vya) ismert (known sec. struct) és valószínüsíthető másodlagos szerkezetének összehasonlítása Phyre2 analízis (Kelley és mtsai., 2015) segítségével. A teli piros nyilak a katalitikus triádot, az üreges piros nyíl a katalitikus triádot támogató Ser AS-at, a kék pontok pedig a FAAH oxianion üreget képző AS-ait jelölik (Shin és mtsai., 2002, Mileni és mtsai., 2008). 


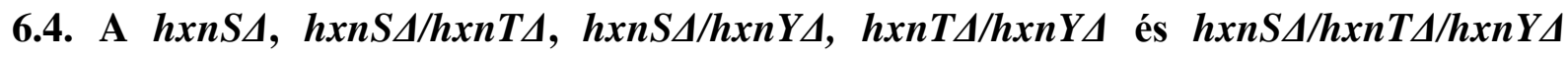 deléciós törzsek létrehozása}

Korábbi munkánk során már deletáltuk az NDC1 klaszter génjeit, és vizsgáltuk a hxnS $\Delta$, $h x n T \Delta$ és $h x n Y \Delta$ szimpla deléciós törzsek NA hasznosítási képességét (Ámon, 2018). A hxnS $\Delta$ törzs NA-at nem, 6-NA-at és 2,5-DP-t azonban képes nitrogénforrásként hasznosítani (Ámon és mtsai., 2017). Mivel a Hx diagnosztikus táptalajon (Hx nitrogénforrás PHI gátló Allp-lal és a NA katabolikus útvonal metabolit inducerével, $1 \mathrm{mM}$ NA-val, 6-NA-val, vagy 2,5-DP-nel kiegészítve) történő növekedés a HxnS működésén alapul, a hxnS $\Delta$ törzs nem képes nőni a diagnosztikus Hx táptalajon (Ámon és mtsai., 2017). A hxnT $\Delta$ és hxnY $\Delta$ törzsek egymáshoz és a vad típushoz hasonló NA hasznosítási fenotípust mutattak, de 6-NA nitrogénforráson a hxnTA törzs növekedése nagy mértékben csökkent, a hxnY $\Delta$ törzs pedig alig észlelhető mértékben mutatott redukált növekedést (Ámon, 2018). A 2,5-DP-t mindkét deléciós törzs a vad típusú törzshöz hasonlóan hasznosította és a diagnosztikus Hx táptalajon is vad típusú módon

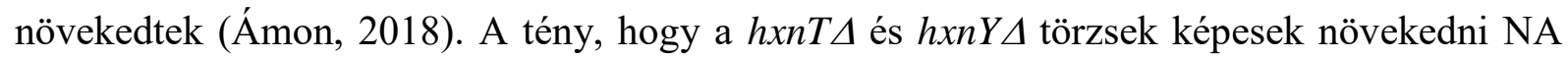
nitrogénforráson, de redukált növekedést mutatnak a NA-tól downstream 6-NA nitrogénforráson arra utalhat, hogy a lebontási útvonal a NA átalakulás kezdeti lépésénél alternatív útvonalakra ágazik el. Az, hogy a hxnT $\Delta$ és $h x n Y \Delta$ törzsek NA hasznosítási profilja minőségileg megegyezik, felveti azt a kérdést is, hogy ugyanazon reakciólépésben vesznek-e részt, vagy egymást követő lépésekben.

A kérdések megválaszolásának céljából a $h x n S$, hxnT és $h x n Y$ génekre nézve halmozottan deléciós mutánsokat hoztunk létre és vizsgáltuk azok NA hasznosítási képességét. A szimpla deléciós törzsek keresztezhetősége érdekében szükségessé vált, hogy a laborunkban

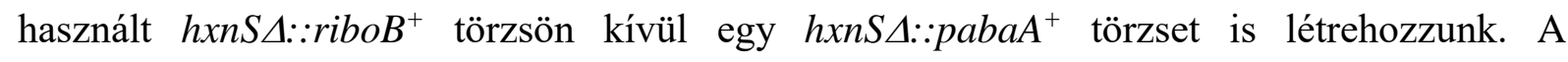
$h x n S \Delta / h x n Y \Delta$ dupla deléciót ugyanis az allélok erős kapcsoltsága miatt csak akkor tudjuk hatékonyan létrehozni keresztezéssel, ha a $h x n S$ és a $h x n Y$ gének deléciója két különböző szelekciós marker génnel történt meg. A laborunkban korábban létrehozott hxnS $\Delta$ és hxnY $\Delta$ deléciós törzsekben a gének mind a két esetben $r i b o B^{+}$marker génnel voltak deletálva, ezért szükségszerü volt az egyik deléció elkészítése újra, egy másik szelekciós marker génnel $\left(p a b a A^{+}\right)$(lásd 6.4.1. alfejezet). Az új, hxnSA::pabaA+ törzzsel és a $h x n Y \Delta:: r i b o B^{+}$törzzsel már olyan genetikai keresztezést tudtunk végrehajtani (hxnS $\triangle:: p a b a A^{+}$, pabaAl, riboB2 keresztezése $h x n Y \Delta:: r i b o B^{+}$, riboB2, pabaAl törzzsel), ahol direkt szelekciót tudtunk végezni a dupla deléciós mutánsok izolálására (lásd 6.4.2.2. alfejezet). A hxnT $\Delta / h x n Y \Delta$ dupla deléciós

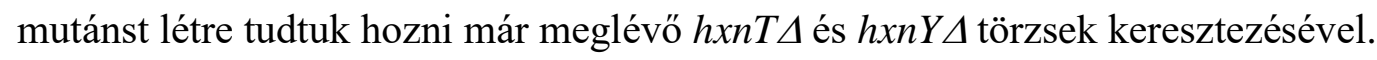


A $h x n S \Delta / h x n T \Delta$ dupla mutánst nem kíséreltük meg keresztezéssel előállítani, mert a szülői törzsekben létrehozott deléciók egymás melletti géneket érintettek, és a két manipulált genomi régió közötti homológia olyan csekély, amely kérdésessé teszi a homológ rekombináció lehetőségét. Ezért a dupla mutáns létrehozását génszubsztitúciós kazetta transzformálásával, egy lépésben hajtottuk végre (lásd 6.4.2.1. alfejezet). A tripla deléciós mutáns létrehozását a $h x n S \Delta / h x n T \Delta$ dupla mutáns és egy hxnY $\Delta$ mutáns genetikai keresztezésével hoztuk létre.

Bár a szóban forgó halmozott deléciós mutánsok jelen doktori munka keretében jöttek létre, ezek NA hasznosítási tesztjeit egy, az NDC1 klaszterre fókuszáló doktori értekezés keretén belül mutattuk be legelőször (Ámon, 2018).

6.4.1. A hxnSA deléciós törzs létrehozása pabaA ${ }^{+}$szelekciós markerrel végzett génszubsztitúcióval

A $h x n S$ gén delécióját $p a b a A^{+}$szelekciós marker génnel végeztük annak érdekében, hogy a riboB ${ }^{+}$szelekciós markerrel deletált törzsekkel történő keresztezést követően egyszerüen szelektálhassunk a dupla deléciós utódokra. A hxnS deléciós törzs létrehozásához egy riboB2, pabaA1 auxotróf (HZS.120) és egy anA1, riboB2, pabaAl auxotróf (HZS.123) törzset használtunk. A génszubsztitúciós kazettát Double-Joint PCR módszerrel (Yu és mtsai., 2004) hoztuk létre $p_{a b a A^{+}}$vad típusú gént használva szelekciós markerként. A kazetta létrehozásához felhasznált indítószekvenciákat a 4. melléklet tartalmazza. A transzformálást követően a para-amino-benzoesavra nézve prototróf, NA nitrogénforrást nem, 6-NA-at azonban hasznosítani képes transzformánsok közül kettő, illetve három törzset választottunk ki Southern analízisre. A Southern-hibridizációs stratégia a 13. ábrán látható. Mindkét transzformálást követően azokat a transzformánsokat választottuk ki a további munkánkhoz, amely a génszubsztitúciós konstrukciót egy kópiában hordozta a cél-lókuszban. Ezek alapján a HZS.120/trf2 (továbbiakban HZS.599), a HZS.123/trf9 (továbbiakban HZS.548), valamint a HZS.123/trf18 (továbbiakban HZS.549) transzformánsokat választottuk ki a vizsgálatainkhoz (17. ábra). 


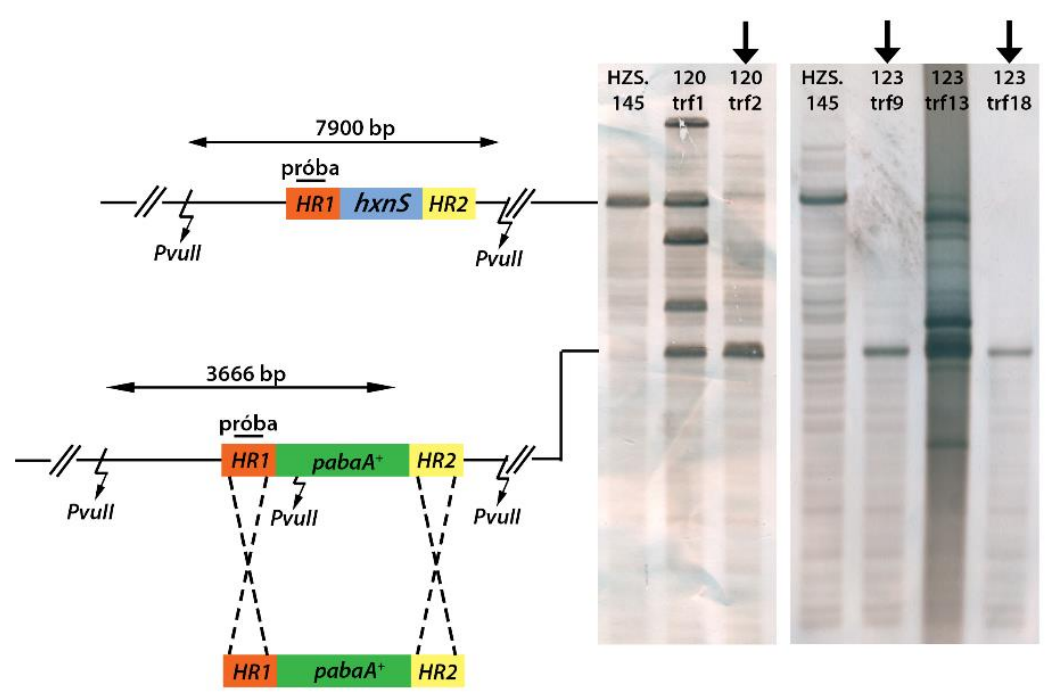

17. ábra: A hxnS gén deléciójának ellenőrzésére használt Southern-hibridizációs stratégia.

A Double-Joint PCR eljárással létrehozott, $p a b a A^{+}$szekvenciát tartalmazó szubsztitúciós kazetta sémája az ábra bal oldalán látható. A narancssárga és sárga téglalapok a targetálást szolgáló, a genomi régióval homológ szakaszokat jelölik (HR1: a deletálás helyétől upstream irányba eső szekvencia, HR2: a deletálás helyétől downstream irányba eső szekvencia). A hxnS $S^{+}$és a potenciális deléciós mutánsok DNS-ét PvuII enzimmel emésztettük (a villám alakú nyilak az PvuII hasítóhelyeket jelölik). Hibridizációs próbának PCR eljárással (hxnS rdown frw és hxnT rev indítószekvenciák, lásd 4. melléklet) felszaporított szekvenciát használtunk, melyet az ábrán ,próba” névvel jelöltünk. A kettős nyilak az PvulI-emésztésből származó termékek méretét jelölik. A jobb oldalon a két Southern-hibridizációs membránt ábrázoltunk a $h x n S^{+}$(HZS.145) és a vizsgált transzformáns törzsek hibridizációs jeleivel. A felső séma az intakt hxnS lókuszt, az alsó a kazetta beépülése esetén létrejövő $p a b a A^{+}$szelekciós markerrel kicserélt lókuszt ábrázolja. A szaggatott vonalak homológ rekombinációs eseményeket jelölnek.

\subsubsection{Többszörösen deléciós törzsek létrehozása}

A már meglévő $h x n T \Delta$ és $h x n Y \Delta$, valamint a 6.4.1. pont alapján létrehozott új $h x n S \Delta$ törzs segítségével létrehoztuk a halmozottan deléciós mutánsokat.

A hxnS $\triangle / h x n T \Delta$ dupla mutáns törzset egy lépésben végrehajtott delécióval hoztuk létre egy Double-Joint PCR módszerrel létrehozott $\mathrm{pabaA}^{+}$szelekciós marker gént hordozó szubsztitúciós kazetta transzformálásával (lásd a 6.4.2.1. alfejezetet).

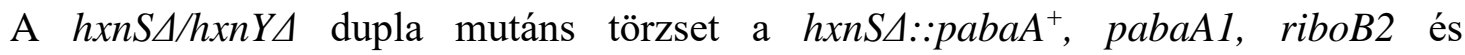
hxnY $\triangle:$ riboB ${ }^{+}$, riboB2, pabaAl törzsek genetikai keresztezésével hoztuk létre (lásd a 6.4.2.2. alfejezetet).

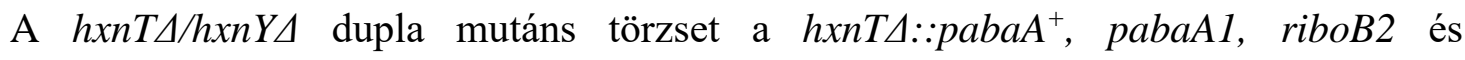
hxnYА::riboB ${ }^{+}$, riboB2, pabaA1 törzsek genetikai keresztezésével hoztuk létre (lásd a 6.4.2.2. alfejezetet).

A $h x n S \Delta / h x n T \Delta / h x n Y \Delta$ tripla mutáns törzset a hxnShxnT $\Delta:: p a b a A^{+}, p a b a A 1$, riboB2 és hxnY $\triangle:: r i b o B^{+}$, riboB2, pabaA1 törzsek genetikai keresztezésével hoztuk létre (lásd a 6.4.2.3. alfejezetet). 


\subsubsection{A hxnS/hxnT dupla deléció létrehozása}

A $h x n S$ és hxnT gének közvetlenül egymás mellett helyezkednek el a genomban, valamint közös promóter régióval rendelkeznek, mely megnehezítette a genommódosított

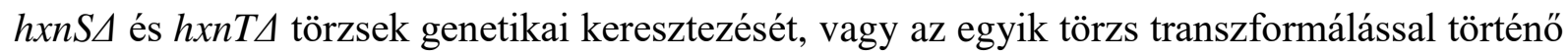
újabb genommódosítását, ezért a mutáns létrehozását a $h x n S$ és hxnT gének egy lépésben történő deléciójával oldottuk meg. A $h x n S$ és $h x n T$ egyedi deléciók szubsztitúciós kazettáinak létrehozásához felhasznált indítószekvenciák kombinálásával készítettünk egy olyan szubsztitúciós kazettát, amelynek segítségével a két gént egyszerre, a közös promóterrel együtt deletálhattuk. A felhasznált indítószekvenciákat a 4. melléklet tartalmazza. A deléciós törzs létrehozásához egy pabaA1, riboB2, pyroA4 auxotróf nkuA4 A. nidulans törzset használtunk (HZS.564) recipiens törzsként. Az $n k u A \Delta$ deléció előnyös egy rekombináción alapuló génmódosítási eljárás esetén, ugyanis nagyrészt az NkuA felelős a nem-homológ rekombinációs események létrejöttéért az A. nidulans-ban. Az NkuA hiányában a nemhomológ végek összekapcsolása nem hatékony, így az $n k u A$ deléciójával a nem-homológ rekombinációs események gyakorisága minimálisra csökken, azaz nagyobb valószínűséggel kerülhető el transzformáláskor az ektopikus integráció eseménye (Nayak és mtsai., 2006). A transzformálást követően 33 para-amino-benzoesavra nézve prototróf transzformáns közül választottuk ki azt a 11 transzformánst, amelyek 6-NA nitrogénforrást tartalmazó táptalajon igen, de NA nitrogénforrást tartalmazó táptalajon nem voltak képesek növekedni. A „hxnT prom frw2” és „hxnT prom rev2” indítószekvenciákkal (4. melléklet) végzett PCR előszelekció alapján a transzformánsok közül négyet választottunk ki Southern analízisre. A Southernhibridizálás három törzs esetében igazolta, hogy a deléciós kazetta csak egy kópiában integrálódott a genomba, melyek közül a trf10 utódot (későbbiekben HZS.568) választottuk ki a további vizsgálatokhoz (18. ábra). 


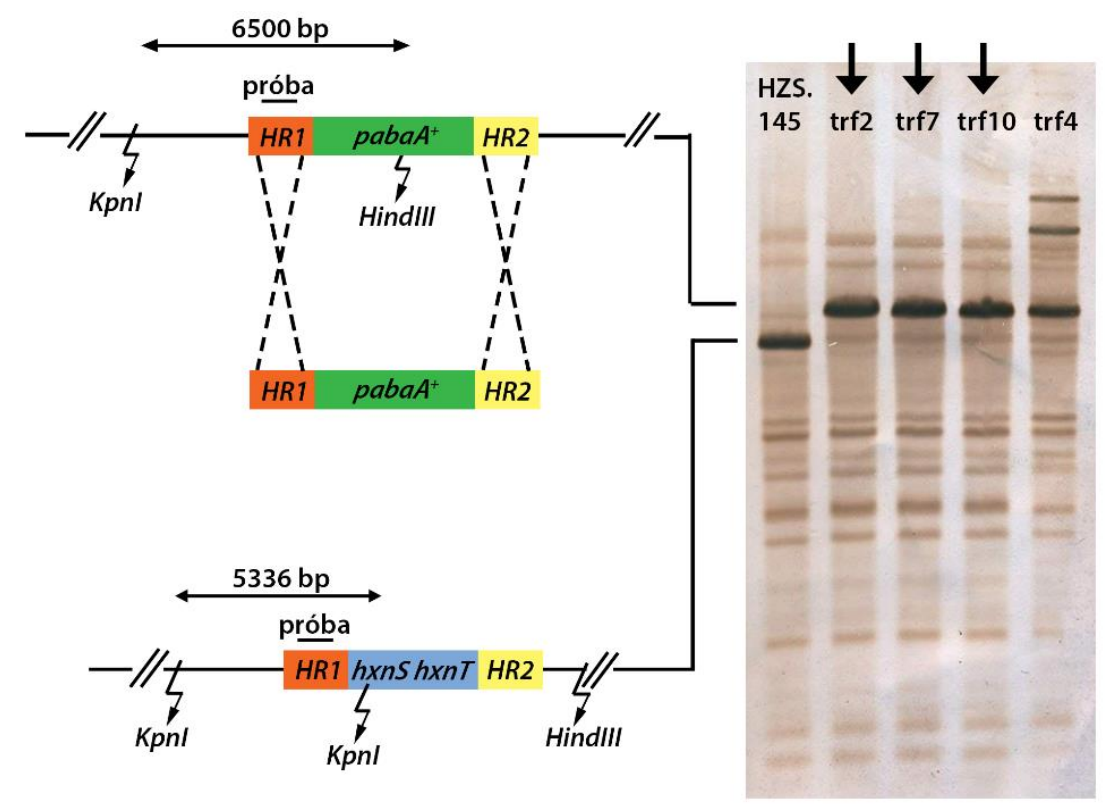

18. ábra: A hxnS/hxnT gének együttes deléciójának ellenőrzésére használt Southern-hibridizációs stratégia.

A Double-Joint PCR eljárással létrehozott, $p a b a A^{+}$szekvenciát tartalmazó szubsztitúciós kazetta sémája az ábra bal oldalán látható. A narancssárga és sárga téglalapok a targetálást szolgáló, a genomi régióval homológ szakaszokat jelölik (HR1: a deletálás helyétől upstream irányba eső szekvencia, HR2: a deletálás helyétől downstream irányba eső szekvencia). A $h x n S^{+} / h x n T^{+}$és a potenciális deléciós mutánsok DNS-ét KpnI/HindIII enzimekkel emésztettük (a villám alakú nyilak a KpnI és a HindIII hasítóhelyeket jelölik). Hibridizációs próbának PCR eljárással (hxnS rup nest frw és hxnS rup rev indítószekvenciák, lásd 4. melléklet) felszaporított szekvenciát használtunk, melyet az ábrán „próba” névvel jelöltünk. A kettős nyilak a KpnI/HindIII-emésztésből származó termékek méretét jelölik. A jobb oldalon a Southern-hibridizációs membránt ábrázoltunk a $h x n S^{+} / h x n T^{+}$(HZS.145) és a vizsgált transzformáns törzsek hibridizációs jeleivel. Az alsó séma az intakt hxnS/hxnT lókuszt, a felső a kazetta beépülése esetén létrejövő $p a b a A^{+}$szelekciós markerrel kicserélt lókuszt ábrázolja. A szaggatott vonalak homológ rekombinációs eseményeket jelölnek.

A létrehozott deléciós törzzsel végzett növekedési tesztek során a 6-NA nitrogénforrást tartalmazó táptalajon történő növekedést megfigyelve meglepő fenotípust tapasztaltunk (Ámon, 2018). A hxnShxnT $\Delta$ törzs sokkal erősebb növekedést mutatott 6-NA nitrogénforráson, mint a vad típusú kontroll (lásd, 6.6. alfejezet). Mivel önmagában a hxnT génre deléciós mutáns erősen csökkent növekedést mutatott 6-NA nitrogénforráson, így a hxnS és hxnT gének együttes deléciója esetén további csökkenést vártunk volna. A tapasztalt paradox fenotípus egyik magyarázata lehet az, hogy a két enzim egyidejü elvesztése egy olyan alternatív útvonalat aktiválhat, vagy egy eddig ismeretlen enzim túltermelődését indukálhatja, amely a 6-NA-at sokkal hatékonyabban képes hasznosítani. Az sem zárható ki, hogy a közös hxnS-hxnT promóter régió elvesztése az útvonal más génjeinek túlmüködéséhez vezet. Ezt a lehetőséget támaszthatja alá, hogy korábbi munkánk során kimutattuk, hogy a katabolikus útvonalra specifikus HxnR transzkripciós faktor limitált mennyiségben termelődik indukció esetén (Ámon és mtsai., 2017). Annak érdekében, hogy kizárhassuk azt a lehetőséget, hogy a közös

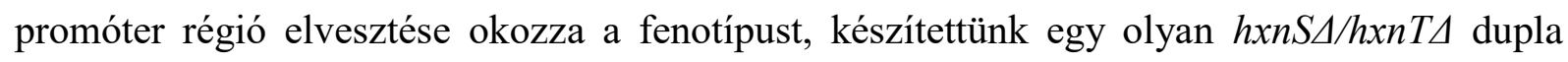


mutáns törzset, amely esetében a 6.4.1. alfejezet alapján elkészített $h x n S \Delta: \because p a b a A^{+}, p a b a A 1$, riboB2 törzsbe (HZS.599) transzformáltunk egy hxnT::riboB ${ }^{+}$szubsztitúciós kazettát. A riboflavin és para-amino-benzoesav nélkül növekedni képes transzformánsok közül a „hxnS ReTi frw” és „hxnS ReTi rev”, valamint a „hxnT frw” és „hxnT rev” indítószekvenciákkal (4. melléklet) végzett PCR előszelekciót követően két transzformáns utódot választottunk ki qPCR-rel történő kópiaszám ellenörzésre, mely alapján megállapítottuk, hogy mind a két transzformáns esetében csak egy kópiában épült be a genomba a szubsztitúciós kazetta. Az egykópiás integrációt hordozó transzformánsokon végzett növekedési teszt, melynek eredményét jelen értekezésben nem mutatjuk be, megerösítette a paradox növekedést, amit a promóterhiányos dupla mutánsnál tapasztaltunk. Azaz, a közös promóter régiót tartalmazó mutáns 6-NA-at tartalmazó táptalajon ugyanúgy a kontroll törzsnél erősebb növekedést mutatott, ahogyan azt a promótert nem tartalmazó HZS.568 dupla mutáns törzs esetében megfigyeltük. Eredményeink alapján tehát a fenotípust nem a közös promóter régió elvesztése okozza. A későbbiekben tovább fogjuk vizsgálni a jelenséget, hogy választ kapjunk a dupla mutáns törzs paradox növekedésére.

\subsubsection{A hxnS/hxnY és hxnT/hxnY dupla deléciók létrehozása}

A hxnS $\Delta / h x n Y \Delta$ dupla deléciós mutáns keresztezéssel (5.7. alfejezet) történő előállításához a korábban létrehozott HZS.223 ( $h x n Y \Delta:: r i b o B^{+}$, riboB2, pabaAl) és a HZS.548

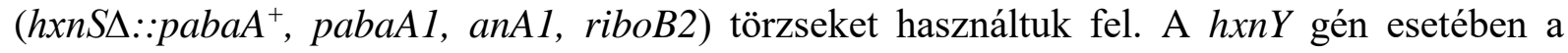
deléció vad típusú riboB ${ }^{+}$génnel, a $h x n S$ gén esetében pedig vad típusú $p a b a A^{+}$génnel történt. Mind a két törzs auxotrófiát hordozott a másik gén kiütéséhez használt vitamin auxotrófia marker génre nézve, amelynek következtében genetikai keresztezéskor csak a deléciós lókuszokban hordozott vad típusú marker gének egyszerre történő öröklődése biztosítja a riboflavint és para-amino-benzoesavat nem tartalmazó táptalajon történő növekedés képességét. A létrehozott dupla mutáns utódok közül egyet választottunk ki a további vizsgálatokhoz, melyet HZS.558-nak neveztük el.

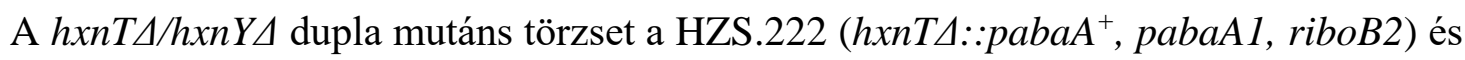
HZS.223 (hxnY $\triangle:: r i b o B^{+}$, riboB2, pabaAl) törzsek genetikai keresztezésével hoztuk létre ugyanazt a szelekciós elgondolást követve, mint a fenti $h x n S \Delta / h x n Y \Delta$ mutáns létrehozásánál. A létrehozott dupla deléciós törzsek közül egyet választottunk ki a további kísérletekhez (HZS.502). 


\subsubsection{3. hxnS/hxnT/hxnY deléció létrehozása}

A 6.4.2.1. alfejezet alapján létrehozott HZS.568 törzs (hxnShxnTA::pabaA ${ }^{+}$, pabaA1, pyroA4, riboB2, nkuA $\left.4:: \arg B^{+}\right)$alkalmas volt arra, hogy a HZS.223 törzzsel (hxnY $\triangle:: r i b o B^{+}$,

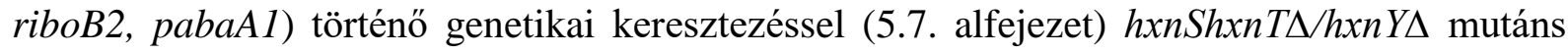
törzset hozzunk létre. Ahogyan a $h x n S \Delta / h x n Y \Delta$ mutáns létrehozásánál, ebben az esetben is direkt tudtunk szelektálni a kívánt utódokra riboflavint és para-amino-benzoesavat nem tartalmazó táptalajon. A létrehozott mutáns törzset HZS.569-nek neveztük el.

\subsection{Az NDC2 és NDC3 gének deléciója}

Az NDC2 és az NDC3 génjeinek delécióját is Double-Joint PCR módszerrel (Yu és mtsai., 2004) létrehozott szubsztitúciós kazetta riboflavin auxotróf (riboB2) recipiens törzsbe történő transzformálásával hajtottuk végre (5.6. alfejezet). Szelekciós markerként minden esetben a vad típusú riboB $B^{+}$gént használtuk. A 4. melléklet tartalmazza az indítószekvenciákat, amelyeket a konstrukciók elkészítéséhez használtunk. A létrehozott deléciós mutánsok minden esetben jól látható fenotípussal rendelkeztek a NA hasznosítási tesztekben (lásd 6.6. alfejezet). Így annak igazolására, hogy a deléciós törzsek fenotípusa valóban az adott gén deléciója miatt következett be és nem valamilyen elöre nem tervezett, egyéb genomi változás miatt, nem az adott gén rekonstitúcióját végeztük el (a vad típusú gén visszajuttatása a deléciós törzsbe transzformálással), hanem a deléciós transzformáns törzsek genetikai keresztezésével kapott utódok vizsgálatával. Mivel a keresztezésekkor a szelekciós marker gén minden deléciós törzs esetében együtt szegregált a deléciós fenotípust eredményező genetikai változással, bizonyítottnak tekintettük, hogy a deléció okozza a megfigyelt fenotípust, így ennek igazolására már külön nem térünk ki.

A $h x n V$ gén deléciójának létrehozásához egy riboB2, pantoB100 auxotróf (HZS.267), valamint egy riboB2, pyroA4 auxotróf A. nidulans törzset használtunk (TN02 A21). Riboflavinra nézve prototróf transzformánsokra szelektáltunk, amelyek közül a „hxnV AS frw” és „hxnV AS rev” indítószekvenciákkal (4. melléklet) végzett PCR alapú előszelekciót követően három transzformáns törzset választottunk ki Southern analízisre. Két transzformáns törzs (185/trf1, a továbbiakban HZS.294 és 185/trf2, a továbbiakban HZS.295) hordozta a cél lókuszba integrált deléciós kazettát ektopikus integrációk nélkül, ezért a további vizsgálatokhoz ezeket a hxnVA törzseket használtuk (19. ábra, A panel).

A $h x n X$ gén deléciójának létrehozásához egy riboB2, biA1, pabaA1 auxotróf $A$. nidulans törzset választottunk (HZS.251) recipiens törzsként. A nyolc, riboflavinra nézve prototróf 
transzformáns közül két törzsben mutatkozott a $h x n X$ gén hiánya a „hxnX frw” és „hxnX NotI rev" indítószekvenciákkal (4. melléklet) végzett PCR előszelekció során. Ezek Southern analízise kimutatta, hogy mind a két törzs esetében csak egy kópiában integrálódott a deléciós kazetta a genomba, a $h x n X$ lókuszba (19. ábra, B panel). A két $h x n X \Delta$ törzset, a HZS.296 (trf4) és HZS.297 (trf7) törzseket használtuk fel a további kísérletek során.

A $h x n W$ gén deléciójának létrehozásához egy riboB2, pantoB100 auxotróf $A$. nidulans törzset alkalmaztunk (HZS.267) recipiens törzsként. A 15 riboflavinra nézve prototróf transzformáns közül 13 törzset választottunk ki Southern-hibridizációra a „hxnW AS frw” és „hxnW AS rev” indítószekvenciákkal (4. melléklet) végzett PCR előszelekció alapján, melyek közül két törzs esetében történt egykópiás integráció a cél lókuszba (19. ábra, C panel). A HZS.393 (trf12) és HZS.394 (trf15) hxnW törzseket használtuk fel a további kísérletekben.

A hxnM gén deléciójának létrehozásához egy riboB2, biA1, pabaAl auxotróf (HZS.251), illetve egy riboB2, pantoB100 auxotróf A. nidulans törzset (HZS.267) alkalmaztunk recipiens törzsként. Az öt HZS.251 eredetű riboflavin prototróf transzformáns közül kettő, a három HZS.267 riboflavin prototróf transzformáns közül pedig egy törzset választottunk ki Southern analízis céljára a „hxnM ReTi frw” és „hxnM ReTi rev” indítószekvenciákkal (4. melléklet) végzett PCR előszelekció alapján. Minden kiválasztott törzs egykópiás integrációt hordozott és a továbbiakban ezek a hxnMA törzsek, HZS.291 (251/trf2), HZS.292 (251/trf5) és HZS.293 (267/trf3) (19. ábra, D panel) képezték a kutatások további tárgyát.

A $h x n N$ gén deléciójának létrehozásához egy riboB2, biA1, pabaAl auxotróf (HZS.251) és egy riboB2, pyroA4 auxotróf (TN02 A21) A. nidulans törzset használtunk. A HZS.251 transzformálásból hat riboflavin prototróf transzformáns közül négy, a TN02 A21 transzformálásból hét riboflavin prototróf transzformáns közül pedig öt törzset választottunk ki Southern analízisre a „hxnN ReTi frw” és „hxnN ReTi rev” indítószekvenciákkal (4. melléklet) végzett PCR előszelekciót követően. Ezek közül négy utód hordozott egykópiás integrációt, a HZS.287 (251/trf5), HZS.288 (185/trf1), HZS.289 (185/trf2) és HZS.290 (185/trf5), melyeket a további kísérleteinkben használtunk fel (19. ábra, E panel). 


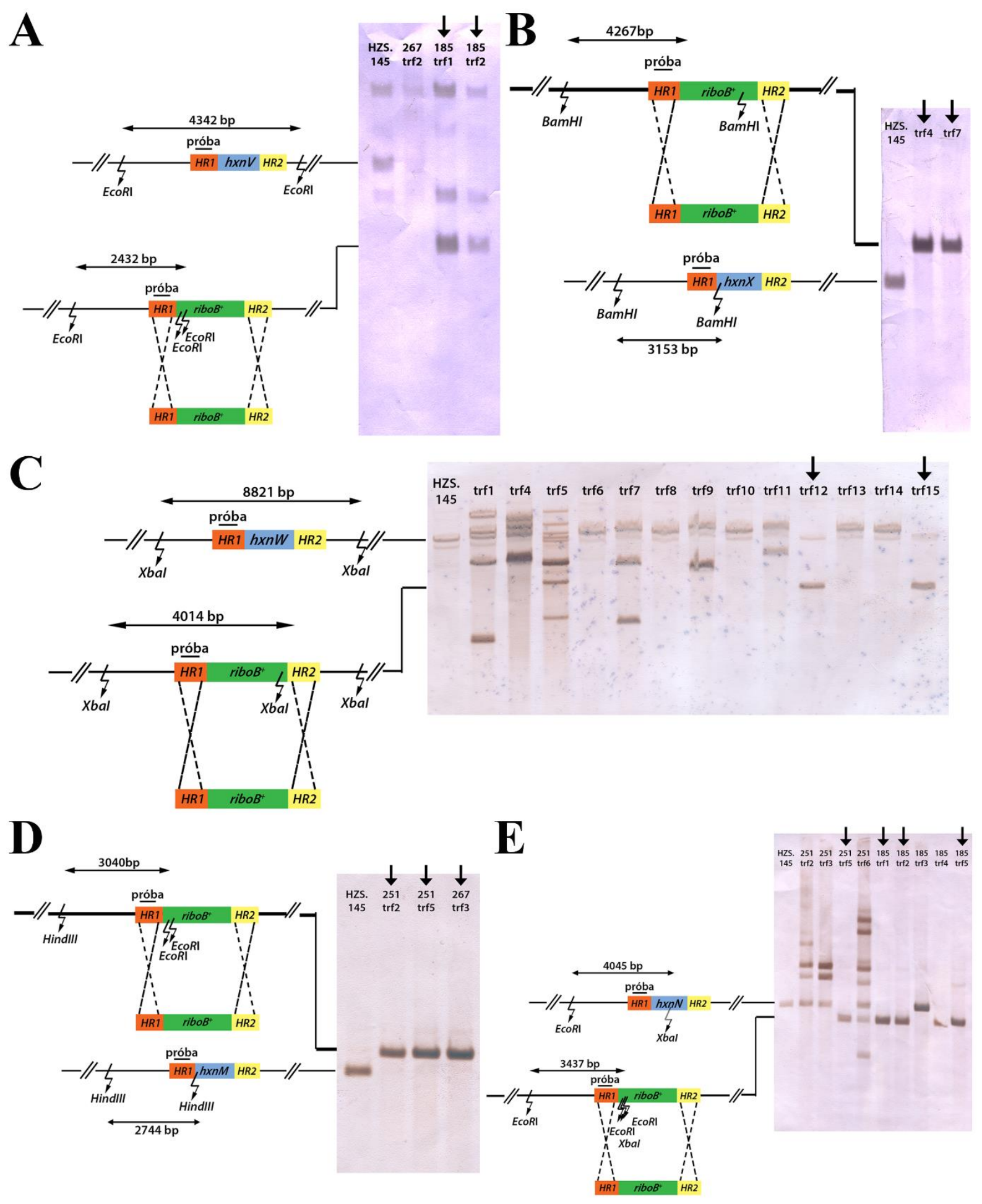

19. ábra: Az NDC2 és NDC3 gének deléciójának ellenőrzésére használt Southern-hibridizációs stratégiák. A Double-Joint PCR eljárással létrehozott, ribo $B^{+}$szekvenciát tartalmazó szubsztitúciós kazetta sémája minden esetben a Southern-hibridizációs membránoktól balra látható. A narancssárga és sárga téglalapok a targetálást szolgáló, a genomi régióval homológ szakaszokat jelölik (HR1: a deletálás helyétől upstream irányba eső szekvencia, HR2: a deletálás helyétől downstream irányba eső szekvencia). A villám alakú nyilak a restrikciós enzimek hasítóhelyeit, a kettős nyilak pedig az emésztésből származó termékek méretét jelölik. A PCR eljárással előállított hibridizációs próbák pozícióját minden esetben „próba” névvel jelöltük. Az A, C és E panelek esetében a felső séma a vad típusú lókuszt, az alsó a kazetta beépülése esetén létrejövő ribo $B^{+}$szelekciós markerrel kicserélt lókuszt ábrázolja, a B és D panelek esetében pedig fordítva. A szaggatott vonalak homológ rekombinációs eseményeket jelölnek. A Southern-hibridizációs membránokon a vad típusú törzs (HZS.145) és a vizsgált transzformáns törzsek hibridizációs jelei láthatóak. A panel: A $\boldsymbol{h} \boldsymbol{x} \boldsymbol{V}$ gén deléciójának ellenőrzésére 
használt Southern-hibridizációs stratégia. A $h x n V^{+}$és a potenciális deléciós mutánsok DNS-ét EcoRI enzimmel emésztettük, a hibridizációs próbát hxnV upst nest frw és hxnV upst rev indítószekvenciákkal (lásd 4. melléklet) szaporítottuk fel. B panel: A $\boldsymbol{h} \boldsymbol{x} \boldsymbol{n} \boldsymbol{X}$ gén deléciójának ellenőrzésére használt Southern-

hibridizációs stratégia. A $h x n X^{+}$és a potenciális deléciós mutánsok DNS-ét BamHI enzimmel emésztettük, a hibridizációs próbát hxnV AS frw és hxnV down nest rev indítószekvenciákkal (lásd 4. melléklet) szaporítottuk fel. C panel: A hxn W gén deléciójának ellenőrzésére használt Southern-hibridizációs stratégia. A $h x n W^{+}$és a potenciális deléciós mutánsok DNS-ét XbaI enzimmel emésztettük, a hibridizációs próbát hxnV AS frw és hxnW upst rev indítószekvenciákkal (lásd 4. melléklet) szaporítottuk fel. D panel: A hxnM gén deléciójának ellenőrzésére használt Southern-hibridizációs stratégia. A $h x n M^{+}$és a potenciális deléciós mutánsok DNS-ét

HindIII és EcoRI enzimekkel emésztettük, a hibridizációs próbát hxnM upst nest frw és hxnM upst rev indítószekvenciákkal (lásd 4. melléklet) szaporítottuk fel. E panel: A hxn $\boldsymbol{N}$ gén deléciójának ellenőrzésére használt Southern-hibridizációs stratégia. A $h x n N^{+}$és a potenciális deléciós mutánsok DNS-ét EcoRI és XbaI enzimmel emésztettük, a hibridizációs próbát hxnN upst nest frw és hxnN upst rev indítószekvenciákkal (lásd 4. melléklet) szaporítottuk fel.

\subsection{Az NDC1, NDC2 és NDC3 génekre deléciós törzsek NA hasznosítási képességének vizsgálata}

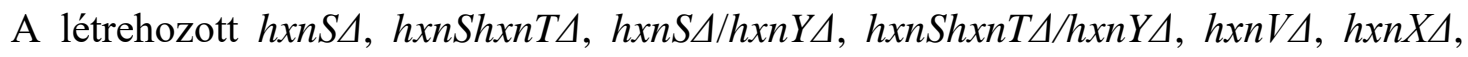
hxnWA, hxnMA és hxnNA deléciós törzsek (HZS.599, HZS.568, HZS.558, HZS.569, HZS.294, HZS.296, HZS.393, HZS.293, HZS.288), valamint a korábban laborunkban létrehozott $h x n R \Delta$, hxnTA, hxnYA, hxnPA és hxnZA (Ámon, 2018) törzsek növekedési képességét Hx diagnosztikus táptalajokon, valamint NA, 6-NA, 2,5-DP és NAA nitrogénforrásokon vizsgáltuk (20. ábra). Mivel a NA, 6-NA és 2,5-DP az útvonal köztes metabolitjai és más ismert nitrogénforrásokhoz képest (ammónium, nitrát, Hx, urea, acetamid, stb.) rendkívül rosszul hasznosulnak, megigyeltük a törzsek növekedési képességét hosszú, hét nap inkubációt követően is (nem mutatott adat). Ebben az esetben a $h x n W \Delta$ törzs kivételével egyik mutáns sem mutatott eltérő növekedési képességet. A hxnWA hosszú inkubációs idő esetén NA, 6-NA és 2,5-DP nitrogénforráson is úgynevezett „leaky” fenotípust mutatott. 


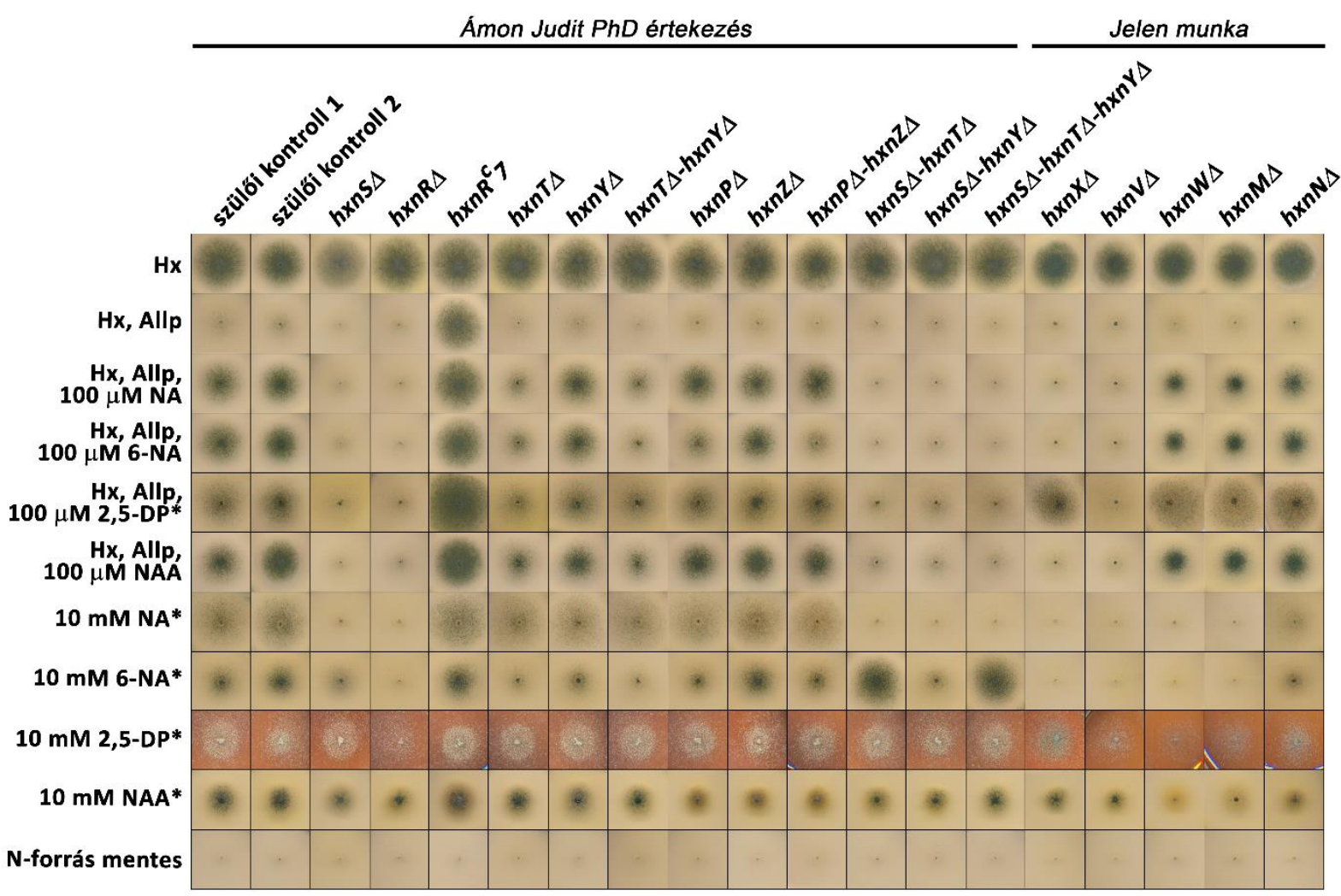

20. ábra: NDC1, NDC2 és NDC3 génekre deléciós törzsek növekedési képességének vizsgálata különböző nitrogénforrásokon.

A „Hx” az 1mM Hx nitrogénforrást tartalmazó táptalajt, a „Hx, Allp” az 5,5 $\mu \mathrm{M}$ Allp gátlószerrel kiegészített, 1 mM Hx nitrogénforrást tartalmazó táptalajt, a „Hx, Allp, $100 \mu \mathrm{M}$ NA” az 5,5 $\mu \mathrm{M}$ Allp gátlószerrel kiegészített, $1 \mathrm{mM} H x$ nitrogénforrást tartalmazó, indukálószerként $100 \mu \mathrm{M}$ NA-at tartalmazó táptalajt, a „Hx, Allp, $100 \mu \mathrm{M}$ 6-NA" az 5,5 $\mu \mathrm{M}$ Allp gátlószerrel kiegészített, $1 \mathrm{mM}$ Hx nitrogénforrást tartalmazó, indukálószerként $100 \mu \mathrm{M}$ 6-NA-at tartalmazó táptalajt, a „Hx, Allp, $100 \mu \mathrm{M}$ 2,5-DP” az 5,5 $\mu \mathrm{M}$ Allp gátlószerrel kiegészített, $1 \mathrm{mM} \mathrm{Hx}$ nitrogénforrást tartalmazó, indukálószerként $100 \mu \mathrm{M}$ 2,5-DP-t tartalmazó táptalajt, a „Hx, Allp, $100 \mu \mathrm{M}$ NAA”

az 5,5 $\mu \mathrm{M}$ Allp gátlószerrel kiegészített, $1 \mathrm{mM}$ Hx nitrogénforrást tartalmazó, indukálószerként $100 \mu \mathrm{M}$ nikotinamidot tartalmazó táptalajt, a „10 mM NA” a NA-at nitrogénforrásként tartalmazó táptalajt, a „10 mM 6 -

NA” a 6-NA-at nitrogénforrásként tartalmazó táptalajt, a „10 mM 2,5-DP” a 2,5-DP-t nitrogénforrásként tartalmazó táptalajt, a „10 mM NAA” a nikotinamidot nitrogénforrásként tartalmazó táptalajt, a „N-forrás mentes" pedig a nitrogénforrást nem tartalmazó táptalajt jelöli. A Hx nitrogénforrást tartalmazó és a nitrogénforrás nélküli táptalajokon három napig, a többi (csillaggal jelölt) táptalajon pedig négy napig növesztettük a törzseket $37^{\circ} \mathrm{C}$-on. Kontroll törzsek: szülöi kontroll 1 (HZS.120), szülöi kontroll 2 (TNO2 A21): az összes $h x n$ gén tekintetében vad típusúak. Mutáns törzsek: $h x n S \Delta$ (HZS.599), $h x n R \Delta$ (HZS.136), hxnR 7

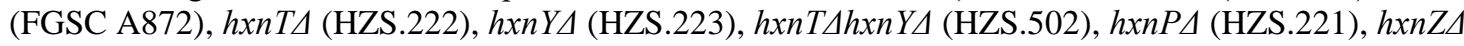

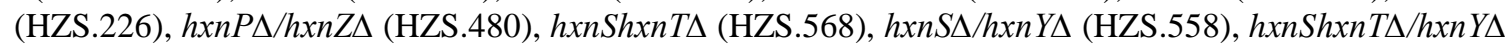
(HZS.569), hxnVA (HZS.294), hxnXA (HZS.296), hxnWA (HZS.393), hxnMA (HZS.293), hxnNA (HZS.288). A felhasznált törzsek teljes genotípusa az 1. mellékletben található meg.

Mielőtt kitérnénk a deléciós törzsek nitrogénforrás hasznosítási eredményének elemzésére, röviden bemutatjuk a $\mathrm{Hx}$ diagnosztikus táptalajok használatának okát. A Hx táptalajt diagnosztikus táptalajnak nevezzük, ugyanis abban az esetben, ha Allp-lal gátoljuk a PHI enzim aktivitását, az egyedüli nitrogénforrásként adagolt Hx hasznosítása csak a HxnS enzim müködésén múlik, amely azonban NA származék inducer nélkül nem termelődik meg. A $\mathrm{Hx}+$ Allp és $\mathrm{Hx}+\mathrm{Allp}+1 \mathrm{mM}$ NA táptalajon történő telepképzésből tehát két információt kapunk a NA katabolikus útvonalról. Az egyik az, hogy képződik-e HxnS enzim, a másik pedig 
az, hogy aktiválódik-e a NA lebontási útvonal. Vad típusú törzs esetén ez utóbbi feltétele az előbbinek. Itt érdemes megjegyezni azt, hogy a NA katabolizmus inducere nem a NA, vagy a 6-NA, hanem egy, a NA lebontása során képződő későbbi köztes metabolit. Tehát a táptalaj tesztek során a NA akkor indukálja a HxnR-en keresztül a katabolikus útvonalat, ha müködnek azok az enzimek, amelyek a valódi inducer metabolithoz vezetnek. Ha akár egy enzim hiányzik a rendszerből, amely a valódi inducer képződéséhez szükséges, akkor annak hiányában a NA lebontási útvonal egyik génje sem aktiválódik, a hxnS sem (Ámon és mtsai., 2017) (jelen dolgozatban a 7. és 9. ábrán látható transzkriptum analízis, nem indukált körülmények). A NA, 6-NA, 2,5-DP és NAA (még $100 \mu \mathrm{M}$ mennyiségben is, lásd 20. ábra) képes indukálni a hasznosítási útvonalat (az inaktívan jelen levő HxnR aktiválásával; Ámon és mtsai., 2017), ezért ha a táptalajban $\mathrm{Hx}$ a nitrogénforrás, és Allp-lal van kiegészítve, akkor inducer jelenlétében a megtermelődő HxnS elvégzi a Hx xantinná alakítását.

Az a tény, hogy a hxnV és a $h x n X \Delta$ törzs nem képes nőni Allp-lal kiegészített $\mathrm{Hx}$ nitrogénforráson egyik inducer jelenlétében sem, a $h x n M \Delta, h x n N \Delta$ és $h x n W \Delta$ törzsek azonban igen, arra enged következtetni, hogy a HxnM, HxnN és HxnW a lebontási útvonal valódi inducerének termelődését követő lépésekért lehetnek felelősek, míg a HxnV és a HxnX a valódi inducertől „upstream” vesznek részt az lebontásban. Azonban ha figyelembe vesszük a $h x n W \Delta$ törzs NA, 6-NA és 2,5-DP nitrogénforrásokon tapasztalt „leaky” fenotípusát, akkor át kell értékelnünk a HxnW pozícióját az útvonalban. A $h x n W \Delta \mathrm{Hx}$ diagnosztikus tesztek során megfigyelt növekedése azzal magyarázható, hogy a HxnW a hxnYA és hxnTA törzsek növekedési tesztje alapján elöre jelzett alternatív útvonalon (Ámon, 2018) vesz részt a lebontásban, így lehetséges, hogy a valódi inducer képződéséhez hozzájárul, de nem nélkülözhetetlen hozzá.

NA és 6-NA nitrogénforráson a $h x n X \Delta$, a $h x n V \Delta$ és a $h x n M \Delta$ mutánsok egyike sem, a $h x n V \Delta$ és a $h x n X \Delta$ pedig még Hx diagnosztikus táptalajon sem képes nőni. Ez arra utalhat, hogy ezen gének termékei a vizsgált NA származékoktól downstream vesznek részt a lebontásban, és mivel a HxnX és a HxnV enzimeket az útvonalban egymás után véljük múködni, valószínű, hogy a HxnX és HxnV-től downstream, de a HxnM előtt képződik a valódi inducer. 2,5-DP nitrogénforráson a hxnVA és hxnM $\Delta$ törzsek nem képeznek telepet (negatív kontrollként a $h x n R \Delta$ törzs növekedését kell figyelembe venni), a $h x n X \Delta$ törzs vad típusú növekedést mutat, míg a $h x n N \Delta$ törzs határozottan, de a vad típushoz képest redukált mértékben képes nőni (20. ábra). Az, hogy a $h x n X \Delta$ mutáns képes növekedni 2,5-DP nitrogénforráson igazolja az in silico vizsgálatok eredményét, miszerint a HxnX 6-NA-ból 2,5-DP-t képezhet. Amennyiben a 2,5-DP nitrogénforráson kapott növekedési teszteket együtt vizsgáljuk a diagnosztikus Hx tesztekkel 
(ahol a hxnV 4 mutáns nem volt képesek növekedni), akkor a NA-at, 6-NA-at, vagy 2,5 DP-t tartalmazó táptalajokon a $h x n V \Delta$ mutáns növekedésének a hiánya egyértelmüen arra utal, hogy a HxnV a 2,5-DP-től downstream helyezkedik el és az útvonal valódi inducere ebben a mutánsban nem jön létre. Ha a valódi inducer hiányában marad el a hxnVA növekedése a diagnosztikus táptalajon, akkor amennyiben a valódi inducerképződés hiányát kiküszöböljük a deléciók konstitutív $h x n R\left(h x n R^{c}\right)$ genetikai háttérbe helyezéssel, akkor igazoljuk állításunkat (lásd 6.7. alfejezet).

A hxnN $\Delta$ törzs NA, 6-NA és 2,5-DP nitrogénforrásokon bár képes növekedni, de csak redukáltan, ami azt jelzi, hogy nem a $\mathrm{HxnN}$ az egyedüli amidáz enzim, amely a végső NA származék amid csoportjának lehasítását végzi.

\subsection{A deléciós törzsek konstitutív $h x n R\left(h x n R^{c}\right)$ háttérbe történő keresztezése NA származék hasznosítási tesztekhez és analitikai vizsgálatokhoz történő mintakészítés céljából}

A NA származék hasznosítási vizsgálatok során az inducerképződés kérdésének kiiktatásához, valamint GC-MS és HPLC-MS vizsgálatokra alkalmas minták előállításához a létrehozott összes $h x n$ deléciót konstitutív $h x n R\left(h x n R^{c}\right)$ háttérbe kellett juttatnunk. A $h x n R^{c}$ jelenléte nem csak függetleníti az útvonalat az inducer metabolit képződésétől, de az útvonal génjeinek kifejeződése is sokkal nagyobb mértékü, amely jól látható a konstitutív mutáns $\left(h x n R^{c} 7\right)$ NA származékokon mutatkozó erőteljesebb növekedésén (20. ábra). A $h x n R^{c}$ hátterü mutánsokban jobban akkumulálódnak a metabolikus köztestermékek, mint a $h x n R^{+}$törzsben. A $h x n V \Delta$ (HZS.294), $h x n M \Delta$ (HZS.293) és $h x n N \Delta$ (HZS.288) törzseket az FGSC A872 hxnR 7 törzzsel, a $h x n X \Delta$ (HZS.296) törzset a HZS.316 hxnR 7 törzzsel, a hxnWA (HZS.394) törzset pedig a HZS.307 $h x n R^{c} 7$ törzzsel kereszteztük és minden esetben a $h x n$ deléciót és $h x n R^{c} 7$ allélt kombinálva hordozó utódokat választottuk ki a további vizsgálatokhoz.

\subsubsection{Deléciós hxnR törzsek növekedésének vizsgálata}

A létrehozott deléciós $h \times n R^{c} 7$ hátterü $h \times n V \Delta, h x n X \Delta, h x n W \Delta, h x n M \Delta$ és $h x n N \Delta$ dupla mutánsok (HZS.309, HZS.310, HZS.517, HZS.308, HZS.306) növekedési képességét vizsgáltuk különböző NA származék nitrogénforrásokon és a diagnosztikus Hx táptalajokon (21. ábra). 


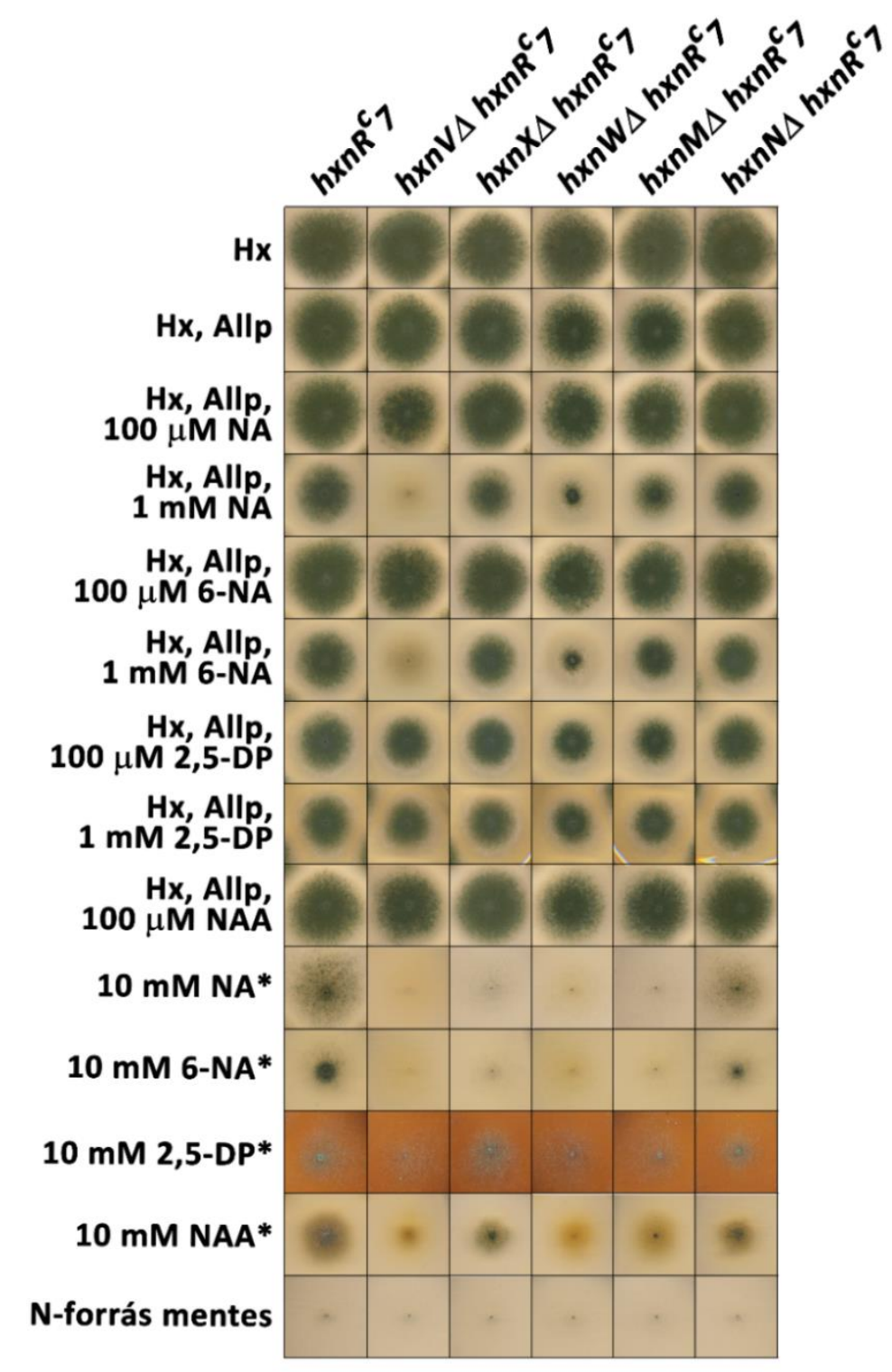

21. ábra: NDC2 és NDC3 génekre deléciós $h x n R^{c} 7$, valamint $h x n T \Delta$ és $h x n Y \Delta h x n R^{c} 7$ törzsek növekedési tesztje különböző nitrogénforrásokon.

A „Hx” az 1 mM Hx nitrogénforrást tartalmazó táptalajt, a „Hx, Allp” az 5,5 $\mu \mathrm{M}$ Allp gátlószerrel kiegészített, 1 mM Hx nitrogénforrást tartalmazó táptalajt, a „Hx, Allp, $100 \mu \mathrm{M}$ NA” az 5,5 $\mu \mathrm{M}$ Allp gátlószerrel kiegészített, $1 \mathrm{mM}$ Hx nitrogénforrást tartalmazó, indukálószerként $100 \mu \mathrm{M}$ NA-at tartalmazó táptalajt, a „Hx, Allp, $1 \mathrm{mM}$ NA” az 5,5 $\mu \mathrm{M}$ Allp gátlószerrel kiegészített, $1 \mathrm{mM}$ Hx nitrogénforrást tartalmazó, indukálószerként 1 mM NAat tartalmazó táptalajt, a „Hx, Allp, $100 \mu \mathrm{M}$ 6-NA” az 5,5 $\mu \mathrm{M}$ Allp gátlószerrel kiegészített, $1 \mathrm{mM} \mathrm{Hx}$ nitrogénforrást tartalmazó, indukálószerként $100 \mu \mathrm{M}$ 6-NA-at tartalmazó táptalajt, a „Hx, Allp, 1 mM 6-NA” az 5,5 $\mathrm{M}$ Allp gátlószerrel kiegészített, $1 \mathrm{mM}$ Hx nitrogénforrást tartalmazó, indukálószerként $1 \mathrm{mM}$ 6-NA-at tartalmazó táptalajt, a „Hx, Allp, $100 \mu \mathrm{M}$ 2,5-DP” az 5,5 $\mu \mathrm{M}$ Allp gátlószerrel kiegészített, $1 \mathrm{mM} \mathrm{Hx}$ nitrogénforrást tartalmazó, indukálószerként $100 \mu \mathrm{M}$ 2,5-DP-t tartalmazó táptalajt, a „Hx, Allp, $1 \mathrm{mM}$ 2,5-DP” az 5,5 $\mu \mathrm{M}$ Allp gátlószerrel kiegészített, $1 \mathrm{mM}$ Hx nitrogénforrást tartalmazó, indukálószerként $1 \mathrm{mM}$ 2,5-DP-t tartalmazó táptalajt, a „Hx, Allp, $100 \mu \mathrm{M}$ NAA” az 5,5 $\mu \mathrm{M}$ Allp gátlószerrel kiegészített, $1 \mathrm{mM} \mathrm{Hx}$ nitrogénforrást tartalmazó, indukálószerként $100 \mu \mathrm{M}$ nikotinamidot tartalmazó táptalajt, a „10 mM NA” a NA-at nitrogénforrásként tartalmazó táptalajt, a „,10 mM 6-NA” a 6-NA-at nitrogénforrásként tartalmazó táptalajt, a „10 mM 2,5-DP” a 2,5-DP-t nitrogénforrásként tartalmazó táptalajt, a „10 mM NAA” a nikotinamidot nitrogénforrásként tartalmazó táptalajt, a „N-forrás mentes” pedig a nitrogénforrást nem tartalmazó táptalajt jelöli. A Hx nitrogénforrást tartalmazó és a nitrogénforrás nélküli táptalajokon három napig, a többi (csillaggal jelölt) táptalajon pedig négy napig növesztettük a törzseket $37^{\circ} \mathrm{C}$-on. Kontroll törzs: $h x n R c 7$ (FGSC A872).

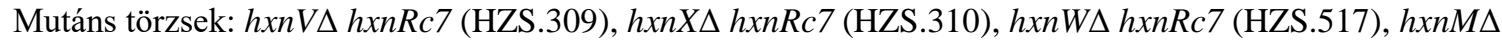
$h x n R c 7$ (HZS.308), hxnNA hxnRc7 (HZS.306). A felhasznált törzsek teljes genotípusa megtalálható az 1. mellékletben. 
A $h x n R^{c} 7$ háttérben a HxnR transzkripciós faktor inducertöl független, folytonosan aktív konformációja és autoregulációja következtében történő konstitutív kifejeződése (Ámon és mtsai., 2017) miatt elméletileg az összes vizsgált $h x n$ mutánsnak nőnie kellett volna mind az inducer nélküli, mind pedig az inducert tartalmazó Hx diagnosztikus táptalajokon. A $100 \mu \mathrm{M}$ inducerrel kiegészített Hx diagnosztikus táptalajokon az összes $h x n$ deléciós mutáns, a vártnak megfelelően, a vad típusú törzzsel megegyező és az inducert nem tartalmazó Hx diagnosztikus táptalajon mutatott mértékben tudott növekedni. Az $1 \mathrm{mM}$ koncentrációban alkalmazott inducer esetén azonban a diagnosztikus Hx táptalajon a $h x n V \Delta h x n R^{c} 7$ (HZS.309) és $h x n W \Delta h x n R^{c} 7$ (HZS.517) törzsek a várttól eltérően viselkedtek (21. ábra). A hxnVA hxnR ${ }^{c} 7$ törzs növekedési képessége 1 mM NA és 6-NA jelenlétében teljesen elmarad, a $h x n W \Delta h x n R^{c} 7$ törzs esetén pedig csökkenést mutat (21. ábra) annak ellenére, hogy inducer nélkül (a konstitutív HxnR miatt elvárt módon) a $\mathrm{Hx}+$ Allp táptalajon még képesek nőni. Ez alapján a táptalajhoz adagolt inducer anyag tehető felelőssé a növekedés elmaradásáért, illetve redukciójáért. Úgy gondoljuk, hogy a $h x n R^{c} 7$ hátterü mutánsban a köztes metabolit túlzott mértékben felszaporodva toxikus a gomba számára, de az is elképzelhető, hogy a konstitutívan aktív HxnR transzkripciós faktort inaktiválja. NA és 6-NA nitrogénforráson a $h x n R^{c} 7$ hátterü $h x n X \Delta, h x n V \Delta, h x n W \Delta$ és $h x n M \Delta$ törzsek nem képesek növekedni, ami inkább a $10 \mathrm{mM}$ szubsztrátból keletkező toxikus anyagfelhalmozásra (vagy a HxnR inaktivációjára) utal, semmint arra, hogy a géntermékek minden esetben a lebontási útvonal elágazás nélküli ágán játszanának szerepet.

A $h x n R^{c} 7 h x n N \Delta$ törzs az eddigi eredményeinkkel összhangban redukált módon képes növekedni 10 mM NA-on, valamint 10 mM 6-NA-on (20-21. ábra)

\subsection{A $h x n V \Delta h x n R^{c} 7$ törzs esetén felhalmozódó kék pigment vizsgálata}

Bakteriális NA lebontási útvonalak esetén több típusú prokarióta útvonalnál előfordul, hogy a 6-NA-at követő di-hidroxilált köztestermékből (2,5-DP, vagy 2,6-DNA) valószínüsíthetően egy tri-hidroxilált piridin metabolikus köztesterméken keresztül nemenzimatikus módon kék színü azakinon pigment képződik (Boyer \& Kruger, 1957). Megfigyeltük, hogy abban az esetben, ha a hxnVA hxnR $R^{c} 7$ mutánst (HZS.309) $5 \mathrm{mM}$ urea nitrogénforrás mellett $10 \mathrm{mM}$ NA-at, vagy $10 \mathrm{mM}$ 6-NA-at tartalmazó táptalajon tenyésztjük, akkor 3-4 nap elteltével a telep körül a táptalaj kékesre színeződik (22. ábra). 


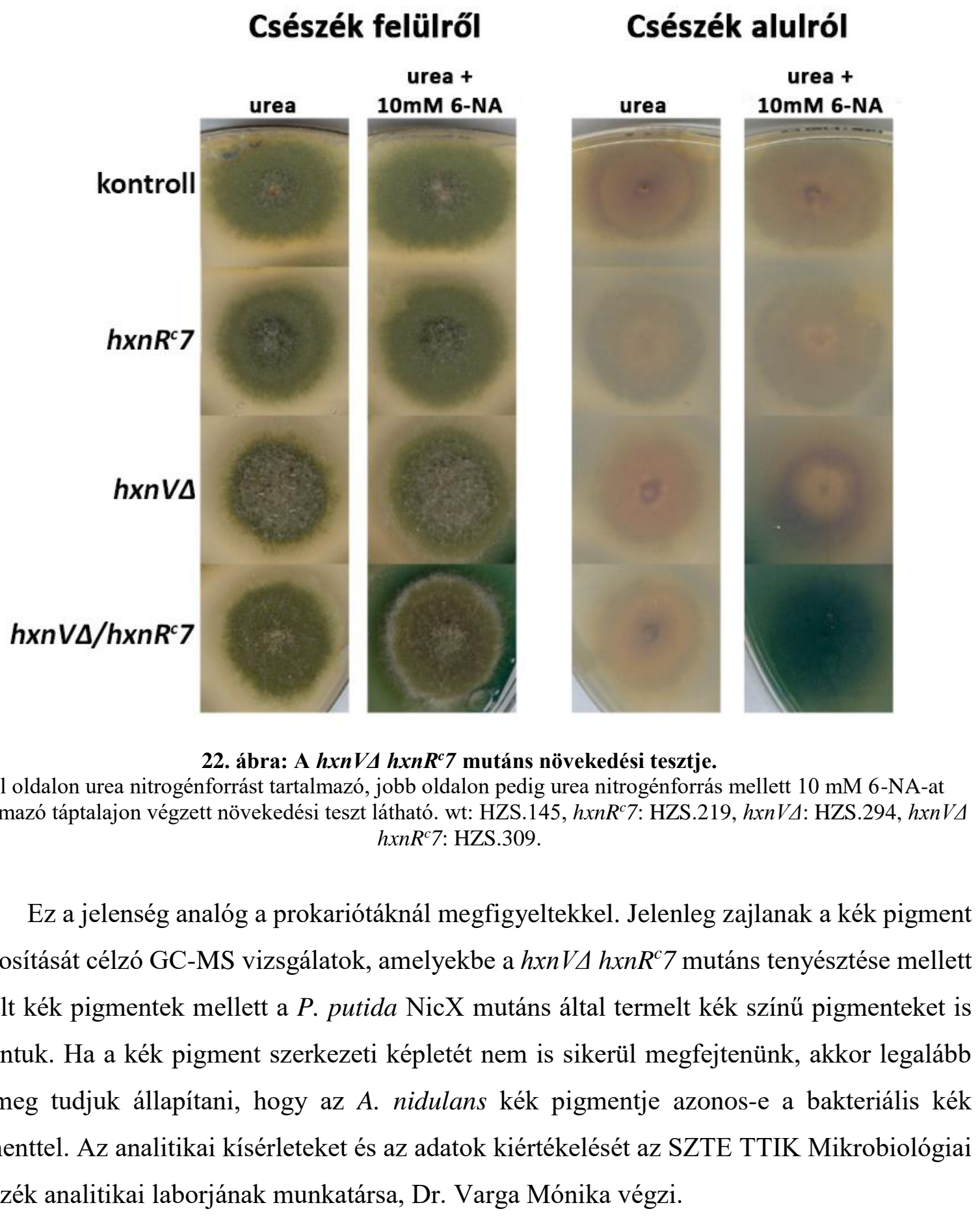




\subsubsection{A kék pigment képzödésének vizsgálata halmozottan deléciós mutánsokban}

Annak érdekében, hogy azonosítsuk a kék pigment képződése előtt müködő enzimeket, a $h x n V$ deléciót különböző $h x n$ deléciókkal kombináltuk $h x n R^{c} 7$ genetikai háttérben, majd a kombinált deléciós törzsekben megvizsgáltuk a pigment termelődést.

A $h x n Y \Delta / h x n V \Delta h x n R^{c} 7$ és $h x n T \Delta / h x n V \Delta h x n R^{c} 7$ dupla deléciós mutánsokat a HZS.429 ( hxnYA::riboB ${ }^{+}$, riboB2, pabaA1, biA1, hxnR ${ }^{c}$ ) és HZS.309 (hxnVA::riboB ${ }^{+}$, riboB2, pyroA4,

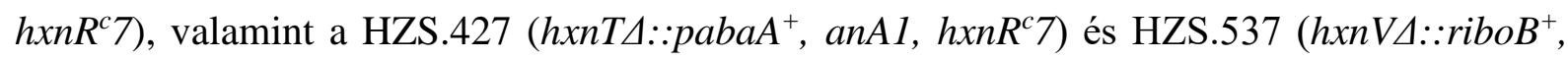
riboB2, pabaA1, $\left.h x n R^{c} 7\right)$ törzsek keresztezésével (5.7. alfejezet) hoztuk létre.

A $h x n Y \Delta / h x n V \Delta h x n R^{c} 7$ esetében azonos szelekciós marker génnel (riboB $\left.{ }^{+}\right)$történtek a géndeléciók, ezért az utódok közül a „hxnY frw” és „hxnY ReTi rev”, valamint a „hxnV AS frw” és „hxnV AS rev” indítószekvenciákkal (4. melléklet) végzett PCR alapú szelekcióval választottuk ki a mind a két génre nézve deléciós törzseket. A létrehozott törzsek közül egyet (pr3) választottunk ki a vizsgálatokhoz, melyet HZS.747-nek neveztünk el.

A $h x n T \Delta / h x n V \Delta h x n R^{c} 7$ törzs esetében a $h x n T$ gén deléciója a vad típusú $p a b a A^{+}$génnel,

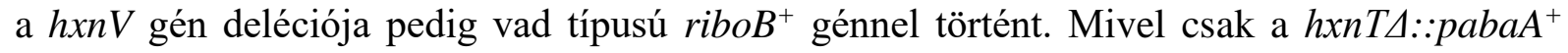
delécióra tudtunk direkt szelekciót végrehajtani, a $h x n V$ deléció esetében a „hxnV AS frw” és „hxnV AS rev” indítószekvenciákkal (4. melléklet) végzett PCR alapú szelekció segítségével választottuk ki a megfelelő dupla deléciós mutánsokat. A létrehozott törzsek közül egyet (pr1) választottunk ki a további vizsgálatokhoz, melyet HZS.748-nak neveztünk el.

A $h x n W h x n V \Delta h x n R^{c} 7$ és a $h x n X h x n W h x n V \Delta h x n R^{c} 7$ törzsek létrehozásához a gének közelsége miatt nem genetikai keresztezést, hanem géndeléciót alkalmaztunk. A deléciós kazettákat az egyedi deléciók szubsztitúciós kazettáinak készítése során alkalmazott indítószekvenciák kombinálásával (4. melléklet) hoztuk létre. Mindkét esetben riboB ${ }^{+}$ szelekciós marker gént építettünk a kazettákba és azokat egy riboB2, pantoB100 hxnR 7 recipiens törzsbe (HZS.404) transzformáltuk. A 25 (hxnWhxnVA) és 38 (hxnXhxnWhxnVA) riboflavinra nézve prototróf transzformánson hxnWhxnVA esetében a „hxnV AS frw” és a „hxnW AS rev”, hxnXhxnWhxnVA esetében pedig a „hxnV AS frw” és „hxnX ReTi rev” indítószekvenciákkal (4. melléklet) hajtottunk végre PCR előszelekciót. Két-két transzformáns törzset választottunk ki Southern analízisre, melyekből egy-egy esetében integrálódott a

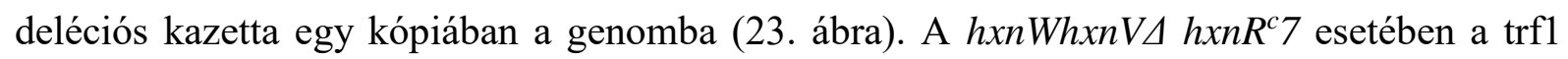

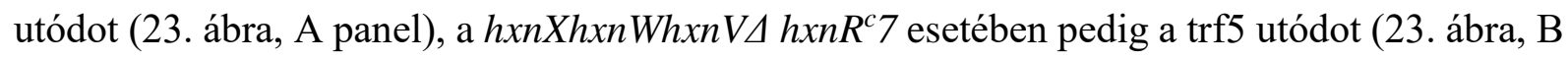
panel) választottuk ki a vizsgálatokhoz, melyeket HZS.749-nek és HZS.750-nek neveztünk el. 


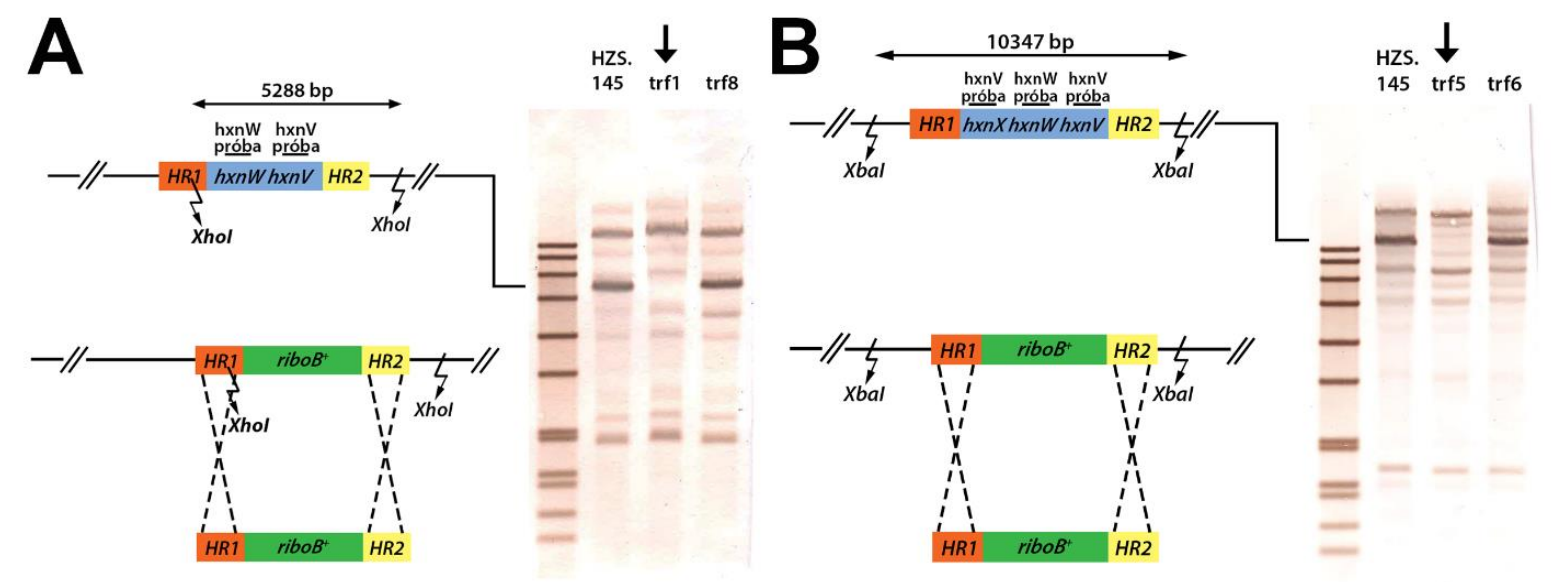

\section{3. ábra: Az hxnWhxnV és a hxnXhxnWhxnV deléciók ellenőrzésére használt Southern-hibridizációs} stratégiák.

A Double-Joint PCR eljárással létrehozott, riboB ${ }^{+}$szekvenciát tartalmazó szubsztitúciós kazetta sémája minden esetben a Southern-hibridizációs membránoktól balra látható. A narancssárga és sárga téglalapok a targetálást szolgáló, a genomi régióval homológ szakaszokat jelölik (HR1: a deletálás helyétől upstream irányba eső szekvencia, HR2: a deletálás helyétől downstream irányba eső szekvencia). A villám alakú nyilak a restrikciós enzimek hasítóhelyeit, a kettős nyilak pedig az emésztésből származó termékek méretét jelölik. Mind a két esetben gén-specifikus hibridizációs próbákat alkalmaztunk, így a deléciós mutánsok esetén nem kaptunk hibridizációs jelet. A PCR eljárással előállított génjelölt hibridizációs próbák pozícióját „,hxnX próba”, „hxnW próba” és „hxnV próba” nevekkel jelöltük. A felső séma a vad típusú lókuszt, az alsó pedig a kazetta beépülése esetén létrejövő riboB ${ }^{+}$szelekciós markerrel kicserélt lókuszt ábrázolja. A szaggatott vonalak homológ rekombinációs eseményeket jelölnek. A Southern-hibridizációs membránokon a vad típusú törzs (HZS.145) és a vizsgált transzformáns törzsek hibridizációs jelei láthatóak. A panel: A $\boldsymbol{h} \boldsymbol{x n} \boldsymbol{W h} \boldsymbol{x n} \boldsymbol{V}$ deléciójának ellenőrzésére használt Southern-hibridizációs stratégia. A vad típusú törzs és a potenciális deléciós mutánsok DNS-ét XhoI enzimmel emésztettük, a $h x n W$ génjelölt hibridizációs próbát hxnW AS frw és hxnW AS rev, a $h x n V$ génjelölt hibridizációs próbát pedig hxnV AS frw és hxnV AS rev indítószekvenciákkal (lásd 4. melléklet) szaporítottuk fel. B panel: A hxnXhxnWhxnV deléciójának ellenőrzésére használt Southern-hibridizációs stratégia. A

vad típusú törzs és a potenciális deléciós mutánsok DNS-ét XbaI enzimmel emésztettük, a $h x n X$ génjelölt hibridizációs próbát hxnX down frw és hxnW down rev,a hxnW génjelölt hibridizációs próbát hxnW AS frw és hxnW AS rev, a hxnV génjelölt hibridizációs próbát pedig hxnV AS frw és hxnV AS rev indítószekvenciákkal (lásd 4. melléklet) szaporítottuk fel.

A létrehozott halmozottan deléciós mutánsokat és a $h x n V \Delta$ hxnR 7 mutánst (HZS.309) előbb 16 órás inkubációval neutrális acetamid nitrogénforráson neveltük fel, majd a micéliumokat szürést követően áthelyeztük 10 mM 6-NA szubsztrátot tartalmazó tápoldatba, és további 24 órán át inkubáltuk öket. A szilárd táptalajon a hxnVA hxnR 7 törzsben kék színünek mutatkozó pigment a tápoldatban zöld színü volt. A színváltozásnak valószínűleg a tápközeg pH eltéréséhez lehet köze, amelyet részletesen a későbbiek során fogunk vizsgálni. Mivel csak a $h x n X$ deléció akadályozta meg a pigment képződését (24. ábra), ezzel kísérletesen bizonyítottuk, hogy a HxnX a HxnV elött müködik az útvonalban, ahogy azt már a korábbiakban is feltételeztük. 


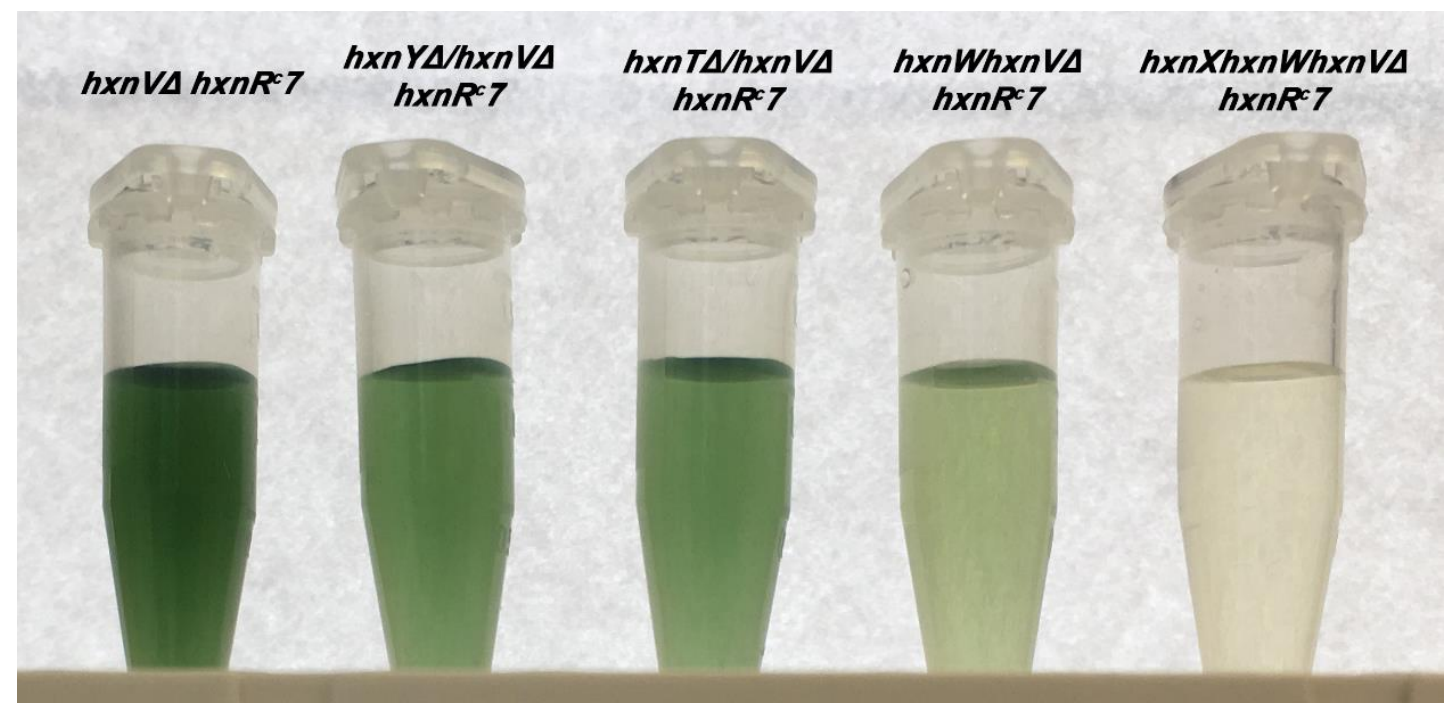

24. ábra: A pigment képződésének vizsgálata a létrehozott halmozottan deléciós mutánsokban. A mutánsokat 16 órán át neutrális acetamid nitrogénforráson neveltük, majd a micéliumokat szürést követően áthelyeztük $10 \mathrm{mM}$ 6-NA szubsztrátot tartalmazó tápoldatba, és további 24 órán át inkubáltuk őket. A micéliumok szürését követően $1 \mathrm{ml}$ tápoldatokat mértünk ki eppendorf csőbe a pigmentáltság dokumentálására.

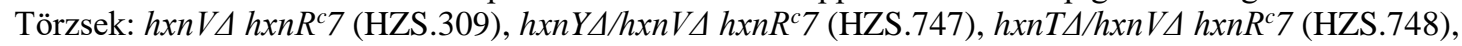
hxnWhxnVA hxnR 7 (HZS.749), hxnXhxnWhxnVA hxnR 7 (HZS.750).

\subsection{Az útvonal intracelluláris színterének vizsgálata GFP-fúziós törzsek létrehozásával és vizsgálatával}

Célunk, hogy mind a 11 hxn gén esetében megvizsgáljuk a kódolt fehérje intracelluláris lokalizációját GFP fúziós törzsek létrehozása és vizsgálata révén. In silico lokalizációs szignál keresést (5.12.2. alfejezet) hajtottunk végre minden hxn géntermék esetén, és az eredmények alapján két Hxn fehérjénél feltételezhetünk kompartmentalizációt. A HxnR, az útvonal transzkripciós faktora, nukleáris lokalizációs szignált (NLS) és nukleáris export szignált (NES) hordoz (Ámon és mtsai., 2017), amely alapján feltételezhető a fehérje sejtmagi lokalizációja. A HxnR lokalizációjának vizsgálata Ámon Judit PhD munkájának (Ámon, 2018) részeként nem képzi tárgyát a jelen értekezésnek.

A másik fehérje, amely esetén kompartmentalizációt feltételezhetünk az elemzések alapján, a HxnX. A C-terminálison azonosított klasszikus peroxiszómás lokalizációs szignál (PTS) szekvencia (SRL) erős indikációt jelentett arra nézve, hogy a fehérje a peroxiszómákban lokalizálódik.

A HxnP és HxnZ fehérjék transzporterek, ezért esetükben membrán lokalizációt feltételezhetünk, amely lehet a citoplazma membránja, vagy valamely intracelluláris kompartment membránja (pl. peroxiszóma, vakuólum, stb.). 
A többi hxn géntermék esetében a szignál kereső programok negatív eredményei alapján nem feltetelezünk kompartmentalizációt. A citoplazmában, esetleg a vakuólumokban várnánk a megjelenésüket.

Jelen dolgozatban a $\mathrm{HxnX}$ lehetséges peroxiszómás lokalizációját, valamint a $\mathrm{HxnV}$ feltételezett citoplazmás lokalizációját vizsgáljuk GFP fúziós konstrukciók létrehozásával és deléciós befogadó törzsben történő kifejeztetésével. A jövőben minden további Hxn fehérjére ki kívánjuk terjeszteni az intracelluláris lokalizáció vizsgálatát.

\subsubsection{A hxnV-gfp fúziós konstrukciót kifejezö törzs létrehozása}

$\mathrm{Az}$ 5.11.1. alfejezetben részletesen leírtak alapján létrehoztunk egy $h x n V$-gfp fúziós fehérjét expresszáló és pantoB ${ }^{+}$szelekciós marker gént hordozó kazettát (,,pantoB ${ }^{+}$hxnV-gfp fúziós kazetta", amelyben a prolin által indukálható prnD promóterről expresszálódik a fúziós gén), melyet egy pantoB100 (pantoténsav auxotróf) hxnVA törzsbe (HZS.304) transzformáltunk. A transzformánsok közül 27 volt képes növekedni pantoténsav nélkül, amelyek közül az előzetes mikroszkópos vizsgálatok alapján hét transzformáns bizonyult megfelelőnek. Ezek közül qPCR segítségével megállapítottuk, hogy a HZS.304 trf25 transzformánsba egy kópiában épült be a konstrukció. Ezt az utódot HZS.555-nek neveztük el és ezt használtuk a mikroszkópos vizsgálatokhoz. Az eredmények alapján nem állíthatjuk, hogy a fehérje a citoplazmában, vagy valamely membránnal körülhatárolt kompartmentben lokalizálódik (25. ábra), mivel a GFP jel változó méretű vezikulumokba koncentrálódik. A jövőben Western-blot analízissel vizsgáljuk meg a fúziós HxnV-GFP fehérje stabilitását, ugyanis elképzelhető, hogy a vizsgálatoknál látható GFP jel a fúziós fehérje degradálódása miatt a vakuólumokban történő felhalmozódásból adódik.

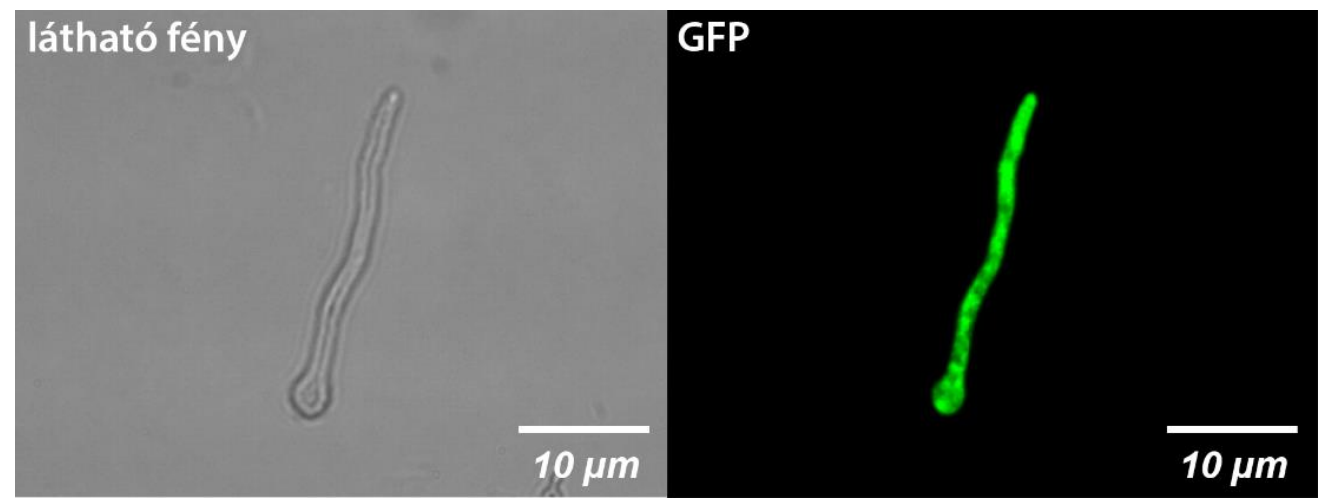

25. ábra: A hxhV-gfp fúziós konstrukciót kifejező törzs mikroszkópos vizsgálata.

A 6-NA-val, biotinnal és para-amino-benzoesavval kiegészített MM tápoldatban felnövesztett HZS.555 törzs Zeiss Axiolab A (Zeiss szürő szett 15) mikroszkóppal végzett vizsgálata. Balra látható a fénymikroszkópos kép, jobbra pedig a HxnV-GFP zöld fluoreszcens jel. 


\subsubsection{A gfp-hxnX fúziós konstrukciót kifejezö törzs létrehozása}

Mivel az in silico vizsgálatok alapján a HxnX fehérje peroxiszómás lokalizációs szignálja (PTS) a C-terminálison található, ezért a GFP fúziót a fehérje $\mathrm{N}$-terminálisára terveztük. A transzformáló konstrukciót az 5.11.2. alfejezetben leírtak alapján készítettük el (,panto $B^{+}$gfp-hxnX fúziós kazetta”). A transzformáláshoz keresztezéssel hoztunk létre egy PTS-RFP-t kifejező (peroxiszómás target jelet hordozó Red Fluoreszcens Protein) pantoB100 (pantoténsav auxotróf) $h x n X \Delta$ törzset (HZS.534), amelyet a „panto $B^{+}$gfp-hxnX fúziós kazettával” transzformáltunk. Az 50 pantoténsav prototróf transzformánsból 14-et választottunk ki előzetes, GFP és RFP jelek megjelenését tesztelő fluoreszcens mikroszkópos vizsgálatokhoz, melyek közül 10 transzformáns esetében láttunk zöld és piros fluoreszcens jelet is. A qPCR-rel végzett kópiaszám meghatározás kimutatta, hogy a transzformánsok egytől 10ig terjedő kópiában hordozzák a fúziós kazettát. A GFP és RFP fluoreszcens mikroszkópos vizsgálatok során minden esetben a GFP-HxnX peroxiszómás lokalizációját figyeltük meg. Mivel az egy kópiában integrálódott kazettát hordozó törzs zöld fluoreszcens jele gyenge volt, a kolokalizáció dokumentálására egy hétkópiás integrációt hordozó transzformáns törzset választottunk (HZS.579), amelyben a zöld fluoreszcens jel összevethető volt a peroxiszómákban lokalizálódó RFP jel intenzitásával. A HZS.579 törzzsel végzett mikroszkópos vizsgálatok alátámasztották a $\mathrm{HxnX}$ fehérje feltételezett peroxiszómás lokalizációját (26. ábra). 


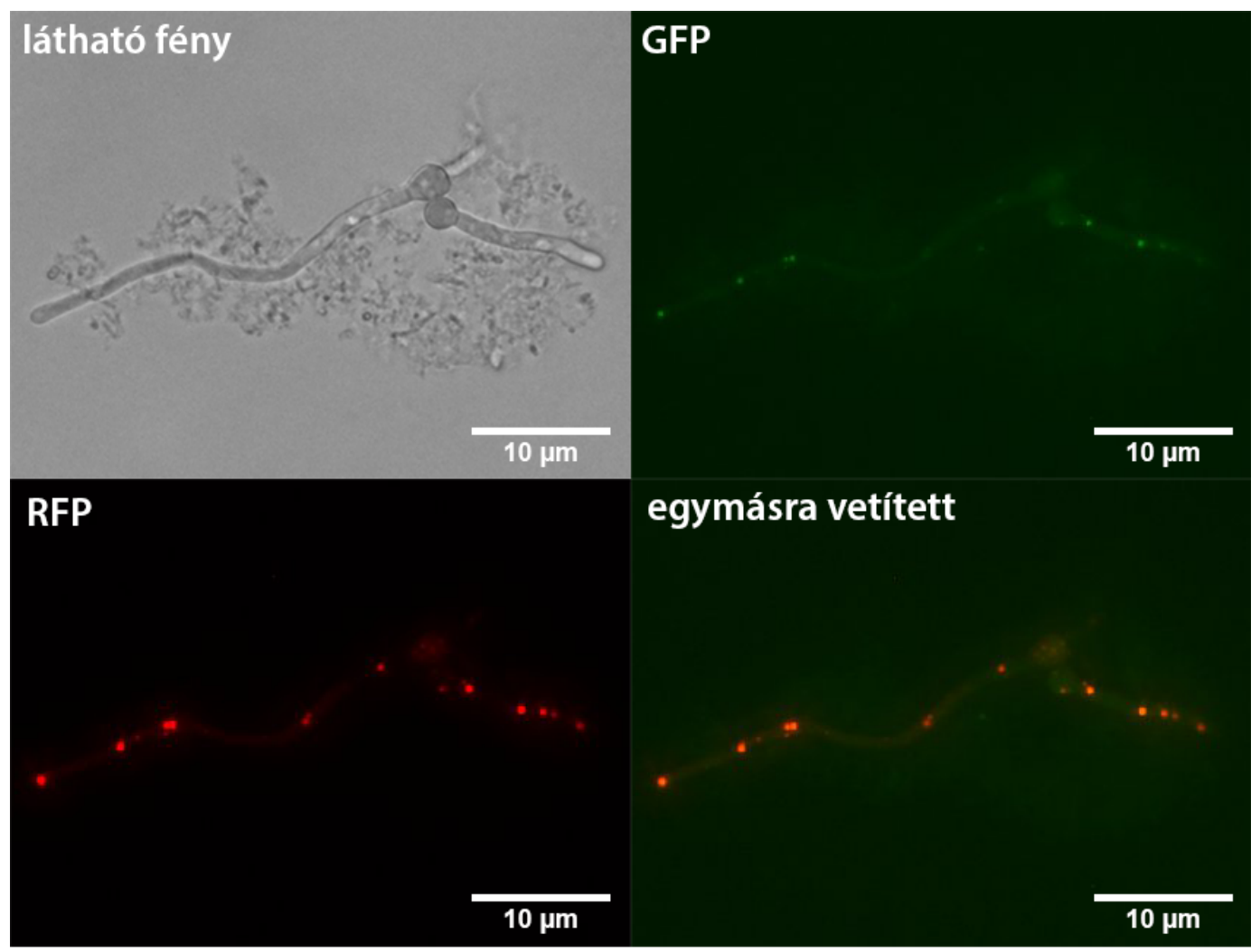

26. ábra: A $g \boldsymbol{f p}$ hxnX fúziós konstrukciót kifejező törzs mikroszkópos vizsgálata.

A 6-NA-val és piridoxinnal kiegészített MM tápoldatban felnövesztett HZS.579 törzs Zeiss Axiolab A (Zeiss szürő szett 09) mikroszkóppal végzett vizsgálata. Balra fent a fénymikroszkópos kép, jobbra fent a GFP-HxnX zöld fluoreszcens jel, balra lent a PTS-RFP vörös fluoreszcens jel, jobbra lent pedig a kolokalizáció vizsgálata látható.

\subsection{További deléciós törzsek létrehozása analitikai vizsgálatokhoz}

Annak érdekében, hogy további információkat gyüjtsünk a lebontás folyamatáról, az analitikai vizsgálatokat nem csak a szimpla, de a rendelkezésünkre álló halmozottan deléciós mutánsokon is elvégeztük. A növekedési tesztek eredményei alapján úgy gondoltuk, hogy a lebontás génjeire nézve deléciós mutánsok kombinálásával fontos információkhoz juthatunk a katabolizmus folyamatáról, ezért az analitikai vizsgálatokhoz további mutáns törzseket hoztunk létre genetikai keresztezéssel.

\subsubsection{A hxnMA/hxnXA dupla mutáns törzs létrehozása analitikai vizsgálati anyagok} elöállítása céljából

A $h x n M \Delta / h x n X \Delta$ dupla deléciós mutáns keresztezéssel (5.7. alfejezet) történő létrehozásához a HZS.293 (hxnMA) és a HZS.297 ( $h x n X \Delta)$ törzseket használtuk fel. Bár mind a két gén riboB ${ }^{+}$szelekciós marker gén segítségével lett deletálva, de eltérő kromoszómán találhatóak, ezért kevés számú utód átvizsgálásával is pozitív eredményt vártunk. Az utódok 
közül a „hxnM ReTi frw” és „hxnM ReTi rev”, valamint a „hxnX frw” és „hxnX NotI rev” indítószekvenciákkal (4. melléklet) végzett PCR előszelekcióval választottuk ki a megfelelő utódokat, majd Southern analízis segítségével ellenőriztük, hogy a kiválasztott törzsek valóban mind a két génre nézve deléciós mutánsok-e (27. ábra, A panel). A létrehozott dupla mutáns utódok közül egyet (pr1) választottunk ki a további vizsgálatokhoz, amelyet HZS.582-nek neveztünk el.

6.10.2. A hxnMA/hxnVA dupla mutáns törzs létrehozása analitikai vizsgálati anyagok elöállítása céljából

A $h x n M \Delta / h x n V \Delta$ dupla mutáns törzs keresztezéssel (5.7. alfejezet) történő létrehozásához a HZS.292 (hxnMA) és a HZS.294 ( $h x n V \Delta)$ törzseket használtuk fel. Ebben az esetben is mind a két törzsben $r i b o B^{+}$szelekciós marker génnel deletáltuk a target géneket, ezért az utódok közül szintén PCR előszelekcióval („hxnM ReTi frw” és „hxnM ReTi rev”, valamint „hxnV AS frw” és „hxnV AS rev” indítószekvenciákkal, 4. melléklet) választottuk ki a mindkét génre nézve mutáns törzseket. Ezt követően Southern analízis segítségével ellenőriztük, hogy a vizsgált törzsek hordozzák-e a deléciót mind a két gén esetében (27. ábra, B panel). A létrehozott dupla mutáns utódok közül egyet (pr1) választottunk ki a további vizsgálatokhoz, amelyet HZS.584-nek neveztünk el.

\subsubsection{A hxnMA/hxnWA dupla mutáns törzs létrehozása analitikai vizsgálati anyagok} elöállítása céljából

A $h x n M \Delta / h x n W \Delta$ dupla deléciós mutánst a HZS.292 ( $h x n M \Delta)$ és a HZS.393 ( $h x n W \Delta)$ törzsek keresztezésével (5.7. alfejezet) hoztuk létre. Ebben az esetben is azonos szelekciós marker génnel $\left(r i b o B^{+}\right)$történtek a géndeléciók, ezért az utódok közül a „hxnM ReTi frw” és „hxnM ReTi rev”, valamint a „hxnW AS frw” és „hxnW AS rev” indítószekvenciákkal (4. melléklet) végzett PCR előszelekcióval választottuk ki a mind a két génre nézve mutáns törzseket. A kiválasztott törzsek esetében Southern analízissel igazoltuk, hogy valóban mind a két génre nézve deléciós mutánsok voltak (27. ábra, C panel). A létrehozott dupla mutáns utódok közül egyet választottunk ki (pr17) a további vizsgálatokhoz, amelyet HZS.588-nak neveztünk el. 

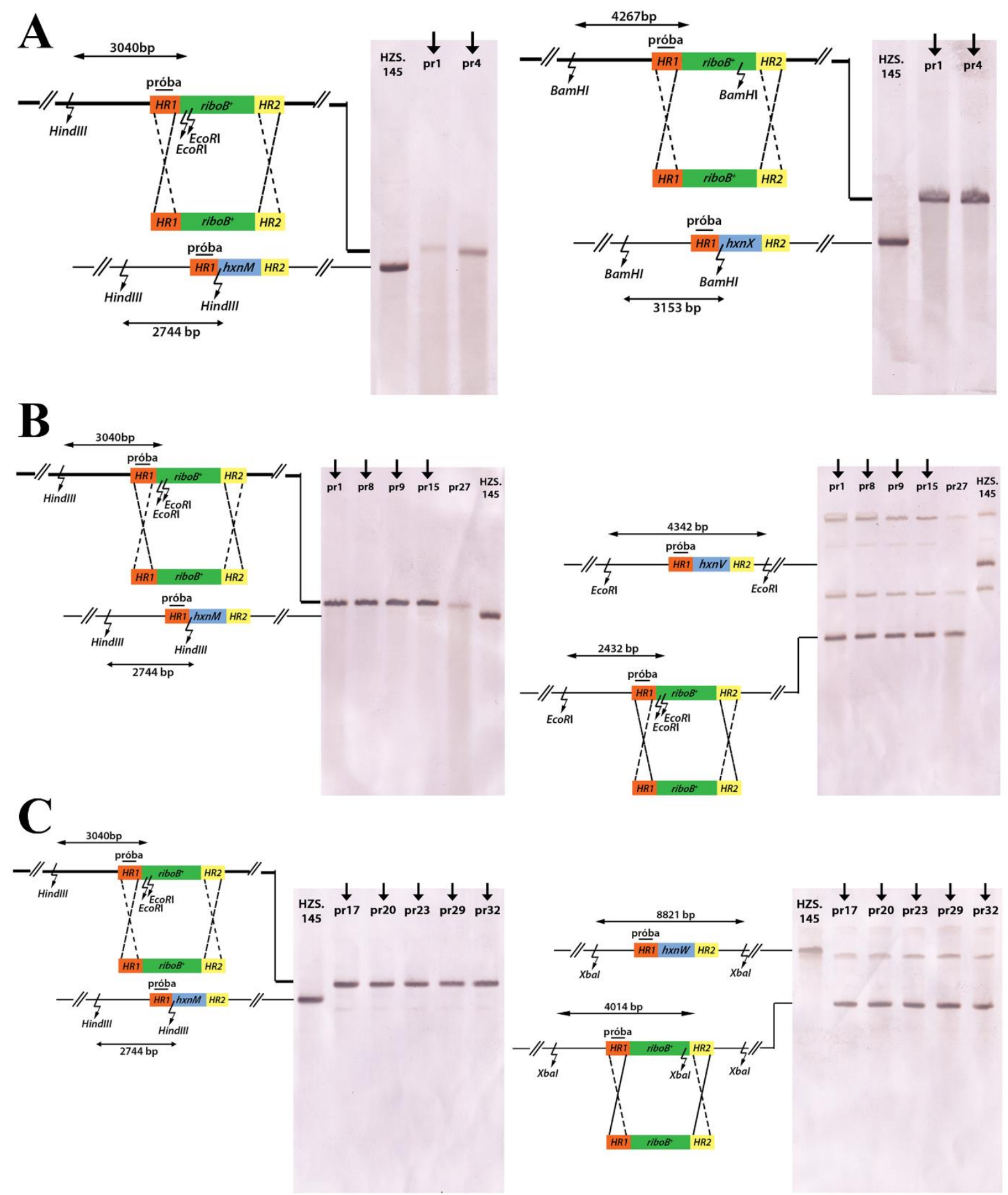

\section{7. ábra: A hxnM/hxnX (A), hxnM/hxnV (B) és hxnM/hxnW (C) mutánsok ellenőrzésére használt Southern-hibridizációs stratégiák.}

A Double-Joint PCR eljárással létrehozott, ribo $B^{+}$szekvenciát tartalmazó szubsztitúciós kazetta sémája minden esetben az ábra bal oldalán látható. A narancssárga és sárga téglalapok a targetálást szolgáló, a genomi régióval homológ szakaszokat jelölik (HR1: a deletálás helyétől upstream irányba eső szekvencia, HR2: a deletálás helyétől downstream irányba eső szekvencia). A $h x n M^{+}$és a potenciális deléciós mutánsok DNS-ét HindIII és EcoRI enzimekkel $(\mathbf{A}, \mathbf{B}, \mathbf{C})$, a $h x n X^{+}$és a potenciális deléciós mutánsok DNS-ét BamHI enzimmel (A), a $h x n V^{+}$ és a potenciális deléciós mutánsok DNS-ét EcoRI enzimmel (B), a $h x n W^{+}$és a potenciális deléciós mutánsok

DNS-ét pedig XbaI enzimmel (C) emésztettük (a villám alakú nyilak a HindIII, EcoRI, BamHI és XbaI hasítóhelyeket jelölik). Hibridizációs próbának PCR eljárással felszaporított szekvenciákat használtunk (hxnM upst nest frw és hxnM upst rev - [A, B, C], hxnV AS frw és hxnV down nest rev - [A], hxnV upst nest frw és hxnV upst rev - [B], illetve hxnV AS frw és hxnW upst rev - [C]; lásd 4. melléklet), melyeket az ábrán „probe” névvel jelöltünk. A jobb oldalon a Southern-hibridizációs membránokat ábrázoltuk a $h x n M^{+}, h x n X^{+}, h x n V^{+}$és 
$h x n W^{+}$(HZS.145) és a vizsgált utód törzsek hibridizációs jeleivel. A hxnX és $h x n M$ esetében az alsó séma az intakt lókuszt, a felső a kazetta beépülése esetén létrejövő riboB $B^{+}$szelekciós markerrel kicserélt lókuszt, a $h x n V$

és $h x n W$ esetében pedig a felső séma az intakt lókuszt, az alsó a kazetta beépülése esetén létrejövő ribo $B^{+}$

szelekciós markerrel kicserélt lókuszt ábrázolja. A szaggatott vonalak a homológ rekombinációs eseményeket jelölik.

\subsection{A deléciós mutánsok GC-MS és HPLC-MS analízissel történő vizsgálata}

A GC-MS és HPLC-MS méréseket és az adatok elemzését az SZTE TTIK Mikrobiológiai Tanszék analitikai mühelyében Dr. Varga Mónika végezte el. A kísérleteinkbe a $h x n P \Delta$ és $h x n Z \Delta$ törzsek kivételével minden $h x n$ génre nézve deléciós törzset bevontunk. A hxnP $\Delta$ és hxnZA törzsekkel azért nem végeztünk méréseket, mert azok transzportereket kódolnak, így közvetlenül nem vesznek részt a NA molekula átalakításában, de a NA, vagy származékainak extracelluláris térből történő felvételével és/vagy intracelluláris transzportjával részei a NA katabolikus rendszernek.

GC-MS és HPLC-MS módszerrel (5.15. és 5.16. alfejezet) vizsgáltuk a $h x n R^{c}$ genetikai

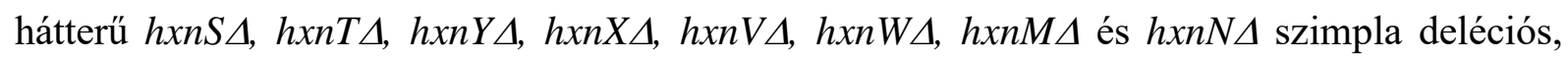
valamint a rendelkezésünkre álló halmozottan deléciós törzseket (hxnShxnTA, hxnS $\Delta / h x n Y \Delta$, hxnT $\Delta / h x n Y \Delta, h x n S h x n T \Delta / h x n Y \Delta, h x n M \Delta / h x n V \Delta, h x n M \Delta / h x n X \Delta, h x n M \Delta / h x n W \Delta)$. A NA és 6NA szubsztrátok felhasználását tesztelő tenyészetekből készített vizsgálati minták metabolit profilját, valamint a negatív kontrollként alkalmazott $h x n R \Delta$ törzs metabolit profilját használtuk az analitikai vizsgálatok során. A tenyésztést nem végezhettük kizárólag NA-on, vagy 6-NAon, hiszen egyes deléciós törzsek nem képesek növekedni ezeken a nitrogénforrásokon, még konstitutív $h x n R^{c}$ genetikai háttérrel sem. Ezért a törzseket előbb 24 órás inkubációval neutrális acetamid nitrogénforráson neveltük fel, majd a micéliumokat szürést követően áthelyeztük 10 mM NA, vagy 10 mM 6-NA szubsztrátot tartalmazó tápoldatba, és különböző ideig tovább inkubáltuk őket. Az adagolt NA, vagy 6-NA szubsztrát fogyását HPLC-UV mérésekkel monitoroztuk, és megállapítottuk, hogy a legoptimálisabb, ha 16 órán át inkubálunk NA-val, vagy 6-NA-val. Ezen inkubációs idő alatt a NA/6-NA szubsztrát fogyás 80\%-os volt és nitrogén éhezés állt be azon mutánsok esetén, amelyek nem tudnak nőni ezeken a nitrogénforrásokon, de még nem mutatták a nekrózis jeleit. Ezért 16 órán túli tenyésztésekkel nem kísérleteztünk. Mivel a HxnS lassú kinetikával alakítja át a NA-at 6-NA-vá (Sealy-Lewis és mtsai., 1979), úgy gondoltuk, hogy hatékonyabb lesz, ha 6-NA szubsztráttal indítjuk az analitikai vizsgálatokat.

A deléciós törzsek 6-NA felhasználását tesztelő vizsgálata során nyert mintákban HPLC-MS segítségével az $\mathrm{m} / z$ 50-500 tömegtartományban detektált összes metabolitot alapul 
véve, az adatokat normalizálva a $h x n R \Delta$ törzs metabolit profiljára, fökomponens analízis végeztünk, melynek eredménye a 28. ábrán látható.

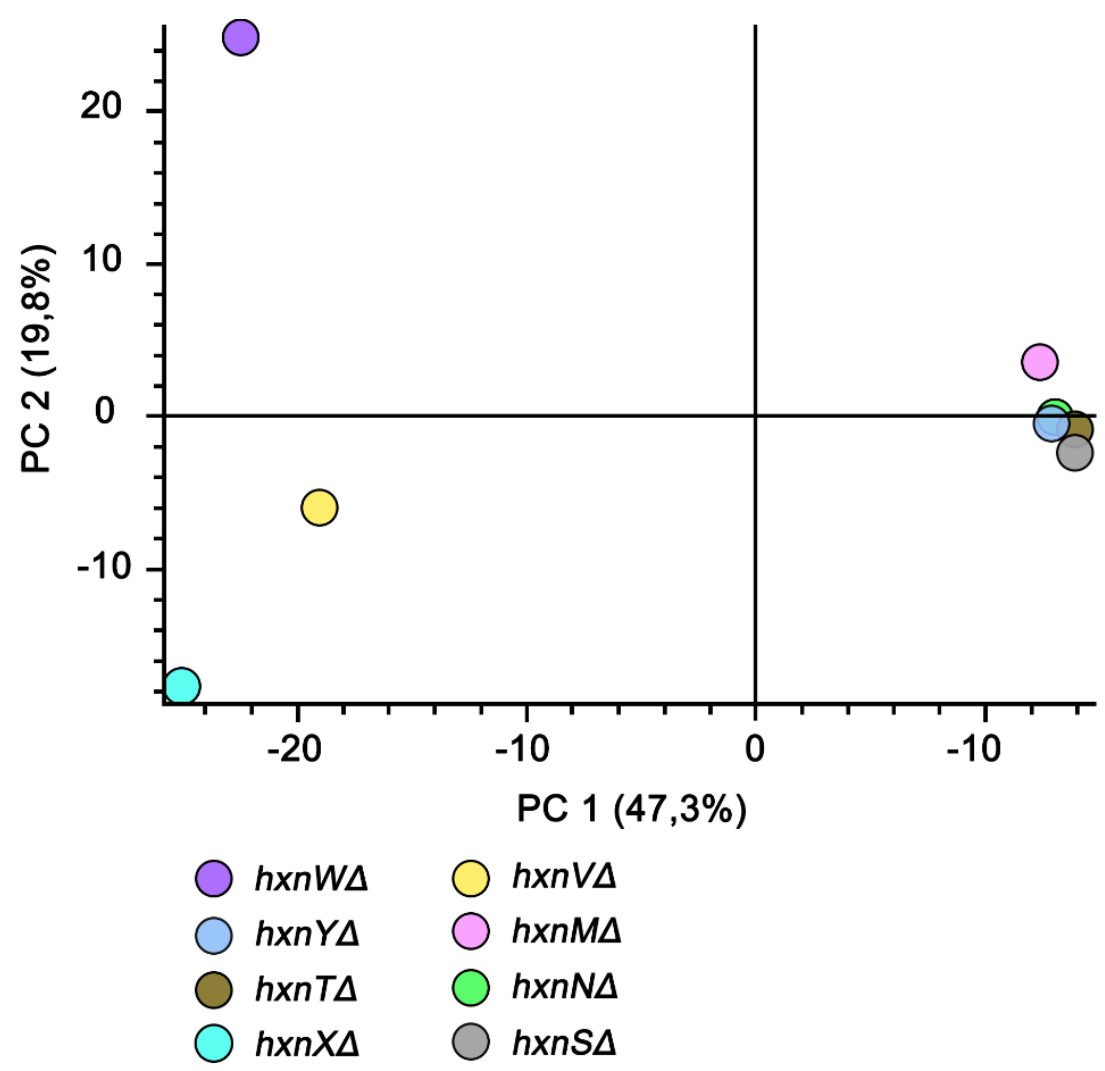

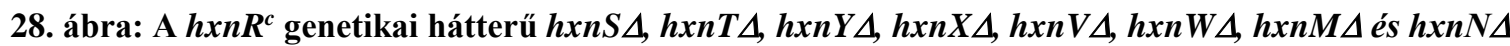
szimpla deléciós mutánsok fökomponens analízise.

A $h x n R^{c} 7 h x n S \Delta, h x n T \Delta, h x n Y \Delta, h x n X \Delta, h x n V \Delta, h x n W \Delta$, hxnM $\Delta$ és $h x n N \Delta$ deléciós mutánsok 6-NA felhasználását tesztelő vizsgálata során nyert mintákban az $\mathrm{m} / \mathrm{z}, 50-500$ tömegtartományban detektált összes metabolitot vettük alapul, melyket a $h x n R \Delta$ törzs metabolit profiljára normalizáltunk.

A fökomponens analízis eredménye alapján a $h x n W \Delta$ mutáns elkülönül az összes többi deléciós törzstől (28. ábra). Ez egybevág azzal az elképzelésünkkel, hogy a HxnW egy alternatív útvonalban játszik szerepet, hiszen hosszú tenyésztési idő alkalmazásával NA-on, 6NA-on és 2,5-DP-en úgynevezett „leaky” fenotípust mutatott. Mivel hasonlóan „leaky” fenotípust a $h x n T \Delta$ és $h x n Y \Delta$ mutánsoknál tapasztaltunk NA és 6-NA nitrogénforrásokon, ezért elképzelhető, hogy ez a három enzim a lebontás egy alternatív utvonalán vesz részt. Jelenleg

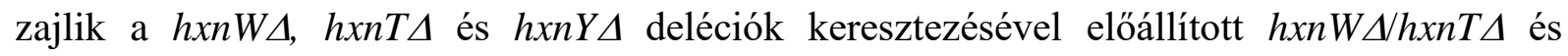

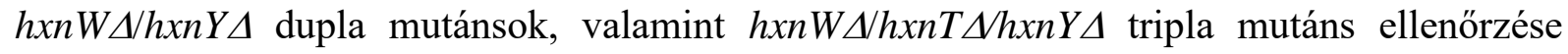
Southern analízissel a további kísérletekbe történő bevonásuk előtt. A $h x n X \Delta$ és $h x n V \Delta$ mutánsok metabolit profilja hasonló volt (28. ábra), amely azt jelezheti, hogy közel állnak egymáshoz a katabolikus útvonalon. Ezt megerősítik a $\mathrm{Hx}$ diagnosztikai táptalajon kapott 
eredmények, amelyek azt mutatják, hogy a HxnX és HxnV a valódi inducer képződés előtti lépéseknél játszanak szerepet, míg a HxnM és HxnN a valódi inducer létrejötte után. Ezen kívül a kék (zöld) színanyag képzését a $h x n V \Delta h x n R^{c} 7$ mutánsban a $h x n X$ deléció megszüntette, ezzel megvilágítva az HxnX és HxnV müködésének sorrendjét a lebontási útvonalban. Az inducer képződésére vonatkozó növekedési tesztek alapján a HxnW-t a valódi inducer képződés utáni lépésekre kellene helyezni a HxnY-nal és HxnT-vel együtt, de ahogy azt az előbbiek során kifejtettük, valószínübb. hogy ez a három enzim a katabolikus út elején, egy alternatív útvonalon szerepelhet, amely megmagyarázza a Hx diagnosztikai táptalajokon megfigyelhető növekedésüket.

A $h x n S \Delta, h x n T \Delta, h x n Y \Delta, h x n M \Delta$ és $h x n N \Delta$ törzsek metabolit profiljuk alapján együtt klasztereződtek, bár a hxnMA mutáns határozottan elkülönült a többi deléciós profiltól (28.

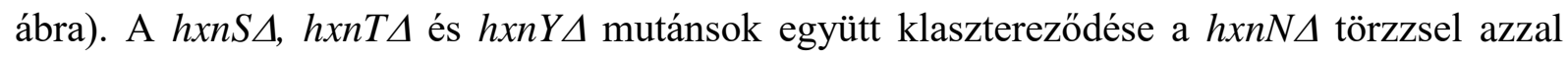
magyarázható, hogy a kiindulási szubsztrát a 6-NA volt és a $h x n S \Delta, h x n T \Delta, h x n Y \Delta$, és $h x n N \Delta$ törzsek mind képesek (bár eltérő hatékonységgal) hasznosítani a 6-NA-at (20. ábra). Így értelemszerüen a 4 deléciós törzs fökomponens profilja nagyon hasonlóan alakul. A hxnM és

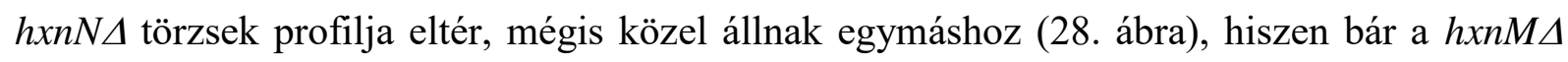
törzs nem képes a 6-NA-at hasznosítani, a HxnM és HxnN enzimek az egyedüliek, amelyek a valódi inducer létrejötte után játszanak szerepet az útvonalban, tehát az útvonal végén, egymás után müködhetnek. Ezek az eredmények megerősítik a HxnM és HxnN in silico funkcióelemzése során prediktált szerepükkel, valamint összhangban vannak a növekedési tesztekkel is (6.3. alfejezet és 20. ábra).

A rendelkezésre álló halmozott deléciós mutánsokban detektált metabolitok a szimpla deléciós mutánsokéval egyező eljárással létrehozott főkomponens analízisének eredményét a 29. ábra mutatja.

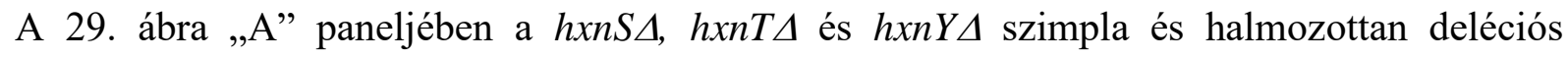
mutánsokra vonatkozó eredményeket ábrázoltuk, mely alapján a három szimpla mutáns egyénileg elkülönül a metabolit profilja alapján. A hxnShxnT $\Delta$ dupla mutáns a $h x n Y \Delta$ szimpla

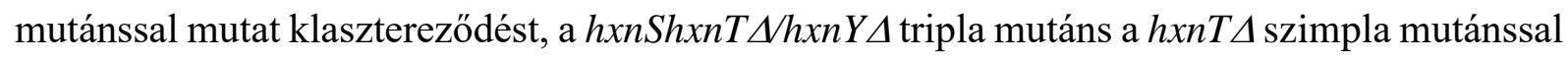
klasztereződik, míg a $h x n T \Delta / h x n Y \Delta$ mutáns nem mutat klasztereződést egyik mutánssal sem. Mindezekből, valamint a növekedési tesztekből (20. ábra) arra következtethetünk, hogy a HxnS után a valószínűleg kettéváló útvonal egyik ágán előbb a HxnY, majd a HxnT következik, a másik ágon pedig egy alternatív út található a HxnW müködésével. 
A 29. ábra „B” paneljében a $h x n X \Delta, h x n W \Delta, h x n V \Delta$ és $h x n M \Delta$ szimpla és a $h x n M \Delta$ előbbi deléciókkal létrehozott dupla deléciós törzsekben ( $x x n M \Delta h x n X \Delta, \quad h x n M \Delta h x n W \Delta$, hxnM $(h x n V \Delta)$ detektált metabolitok fökomponens analízisének eredménye látható. Minden

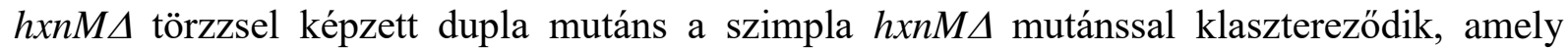
megerősíti az alternatív útvonal meglétét, hiszen a dupla mutáns törzsekben csak abban az esetben juthat el a lebontás a $h x n M$ génik, ha a $h x n X$, a $h x n V$, vagy a $h x n W$ gének hiánya önmagában nem gátolja meg a lebontás eljutását a közös szakaszig, ahol azonban a hxnM gén hiánya miatt megáll a lebontás.
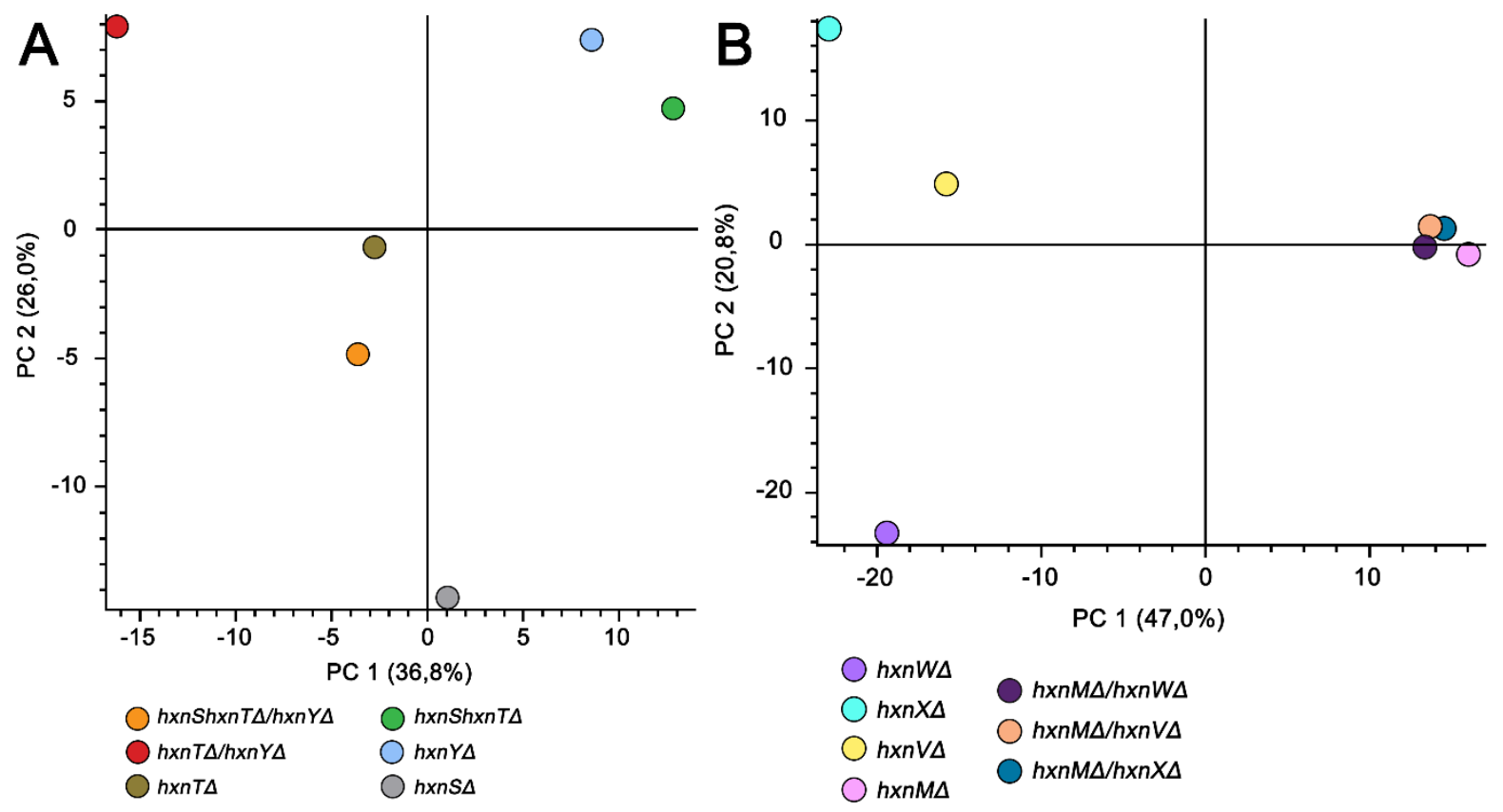

29. ábra: A szimpla és a halmozottan deléciós mutánsok fókomponens analízise.

A panel: a $h x n S \Delta, h x n T \Delta, h x n Y \Delta, h x n T \Delta / h x n Y \Delta, h x n S h x n T \Delta$ és $h x n S h x n T \Delta / h x n Y \Delta$ deléciós mutánsok 6-NA felhasználását tesztelő vizsgálata során nyert mintákban a HPLC-MS analízis során az $\mathrm{m} / z$ 50-500 tömegtartományban detektált összes metabolitot vettük alapul, melyket a $h x n R \Delta$ törzs metabolit profiljára normalizáltunk. B panel: a $h x n M \Delta, h x n V \Delta, h x n X \Delta, h x n W \Delta$, hxnMA/hxnVA, hxnM $4 / h x n X \Delta$ és $h x n M \Delta / h x n W \Delta$ deléciós mutánsok 6-NA felhasználását tesztelő vizsgálata során nyert mintákban az $\mathrm{m} / \mathrm{z}$ 50-500 tömegtartományban detektált összes metabolitot vettük alapul, melyket a $h x n R \triangle$ törzs metabolit profiljára normalizáltunk.

A metabolomok egyes komponenseinek vizsgálata során két kivétellel az egyes metabolitok egynél több $h x n$ mutáns metabolit profiljában is előfordultak. Ez a jelenség a metabolitok reverz irányú átalakulásával, valamint az enzimek eltérő kinetikával történő müködésével és a köztes metabolitok stabilitásával állhat összhangban. A két kivételt képző metabolit közül az egyik a $111 \mathrm{~g} / \mathrm{mol}$ molekulasúlyú 2,5-DP volt, amely csak a hxnVA 
mutánsban halmozódott fel (30. ábra „A” panel). Ez alapján valószínüsíthetően a $\mathrm{HxnV}$ szubsztrátja a 2,5-DP. A másik metabolit egy 131g/mol molekulasúlyú vegyület volt, amelynek összetétele $\mathrm{C}_{5} \mathrm{H}_{9} \mathrm{O}_{3} \mathrm{~N}$ és kizárólag a hxnW $\Delta$ mutánsban halmozódott fel (30. ábra „B” panel). Figyelembe véve a vegyület összetételét és $\mathrm{MS}^{2}$ spektrumát (5. melléklet), feltételezzük, hogy a molekula az 1,2,3,6-tetrahidro-piridin-2,3,6-triol. Ez alapján elmondhatjuk, hogy a HxnW szubsztrátja valószínüleg az 1,2,3,6-tetrahidro-piridin-2,3,6-triol, ami a B. niacini-ben található 2,3,6-trihidroxi-piridin köztesterméknek (Ensign \& Rittenberg, 1964) egy kevésbé telített származéka. Kerestük a metabolitok között azokat a vegyületeket, amelyek a prokariótáknál a piridingyürü felnyílását követően alakulnak ki, különös tekintettel az N-formil maleinsavamid és a maleinsavamid köztes metabolitokra, azonban egyik mérés során sem tudtuk ezeket a vegyületeket kimutatni a mintáinkból. Ennek magyarázata az lehet, hogy ezek a vegyületek instabilak, vagy az, hogy nem képzik részét az A. nidulans NA katabolizmusának.

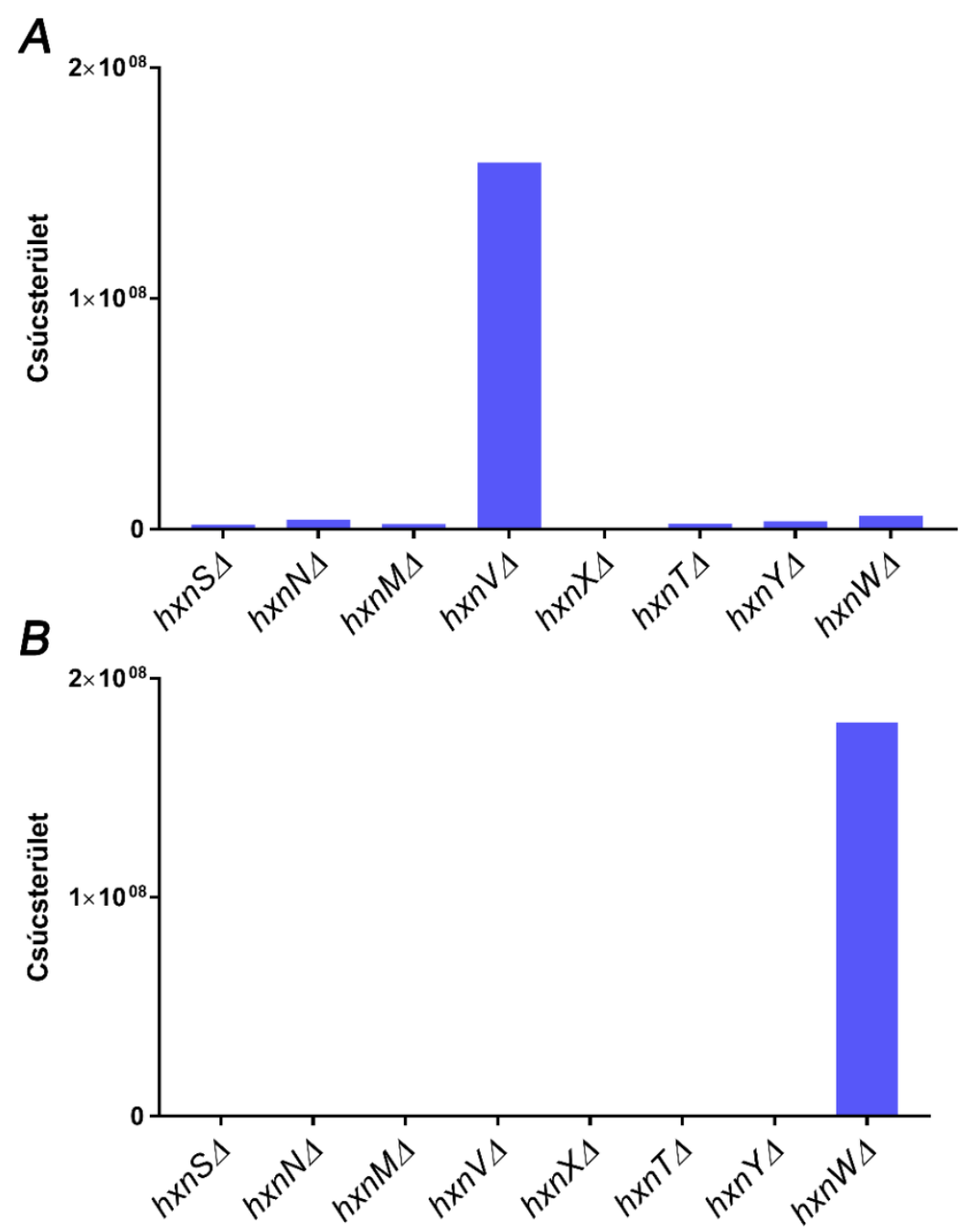

30. ábra: A 2,5-DP és a 131g/mol molekulasúlyú vegyület felhalmozódásának HPLC-MS mérési adatai. $\mathrm{Az}$ „A" panel mutatja a 2,5-DP felhalmozódását a hxnV 4 mutáns törzsben acetamid nitrogénforrást tartalmazó tápoldatban történő előtenyésztést $\left(37^{\circ} \mathrm{C}, 24\right.$ óra ) követő $10 \mathrm{mM}$ 6-NA szubsztráton történő inkubálás $\left(37^{\circ} \mathrm{C}, 16\right.$ 
óra) után. A „B” panelen a 131g/mol molekulasúlyú vegyület (feltételezett 1,2,3,6-tetrahidro-piridin-2,3,6-triol) felhalmozódása látható a $h x n W \Delta$ törzsben az „A” panelben részletezett tenyésztési körülmények mellett.

Figyelembe véve, hogy a bakteriális NA katabolikus útvonalak csak egyetlen vonalon történnek, az A. nidulans esetén azonban egyes átalakulások alternatív úton is történhetnek, valamint hogy azonosítottunk olyan metabolitot, amelyet a prokarióta útvonalaknál eddig nem figyeltek meg, igazolja azt a kezdeti elképzelésünket, hogy az eukarióta lebontási útvonal eltér a prokariótáknál megismert útvonalaktól.

Jelenleg minden hiányzó halmozottan deléciós mutáns előállítása folyamatban van, amely a $h x n$ deléciókat az összes kombinációban lefedi. Elképzelésünk szerint ezek metabolom vizsgálata egyrészt megerősítheti a már elöre jelzett útvonal lépéseket, másrészt pedig számos, eddig ismeretlen lépésre deríthet fényt. 


\section{7. ÖSSZEFOGLALÁS}

Annak ellenére, hogy a természetben számos mikroorganizmus képes a nikotinsavat (NA) nitrogénforrásként hasznosítani, a lebontás folyamatát eddig mégis mindössze prokarióták esetében tanulmányozták. Eukariótákban teljesen ismeretlen a katabolizmus folyamata annak ellenére, hogy az Aspergillus nidulans-ról már az 1970-es évek óta tudják, hogy képes a NA hasznosítására és jellemezték a lebontási út első lépését végző enzimet, a PHII-t (későbbiekben HxnS), valamint NA-at nem hasznosító mutánsokat izoláltak. A PHII megismerése érdekes módon a purin hasznosítási útvonal vizsgálatához kapcsolódik. A purin hasznosítási útvonalban szereplő $h x A$ gén termékéről, a purin hidroxiláz I (PHI) enzimről régóta ismert, hogy képes a hipoxantin (Hx) xantinná, majd a xantint húgysavvá alakítani. A $h x A$ génre nézve mutáns törzsek elemzése során fedezték fel a PHII enzimet, amely szintén képes a Hx-t xantinná alakítani, azonban a xantin $\rightarrow$ húgysav átalakításra képtelen. A vizsgálatok során kiderítették, hogy a PHII enzim a Hx mellett a NA-at is képes szubsztrátként hasznosítani és 6hidroxi-nikotinsavvá (6-NA) alakítani. A 2000-es években kutatócsoportunk megkezdte az első eukarióta NA lebontási útvonal felderítését $A$. nidulans modellszervezetben. Kísérleteink során azonosítottuk a PHII enzimet kódoló hxnS gént (AN9178), valamint a lebontási útvonal transzkripciós faktorának génjét, a $h x n R$-t (AN11197). Az ezekkel szomszédos gének vizsgálata során további négy olyan gént ( $h x n T, h \times n Y$, $h x n P$ és $h x n Z)$ találtunk, amelyek a $h x n S$ hez hasonlóan a $h x n R$ gén szabályozása alatt állnak és kifejeződésük a NA-tól és annak downstream származékaitól függ. A felfedezett hat génből álló klasztert NDC1-nek neveztük el. Munkánk során az NDC1 klaszterbe tartozó génekre nézve deléciós mutánsokat hoztunk létre, melyek különböző nitrogénforrásokon végzett növekedési tesztjei alapján arra a következtetésre jutottunk, hogy további, még ismeretlen gének is részt vesznek a NA lebontásának folyamatában.

Annak érdekében, hogy kiderítsük, melyek ezek az eddig ismeretlen gének, egy, az 1970-es évekből származó hxn6 elnevezésű mutáns vizsgálatába kezdtünk, amely nem képes nitrogénforrásként hasznosítani sem a NA-at, sem pedig a 6-NA-at. Mivel az 1970-es években a hxn6 lókuszt az NDC1 klaszterben található hxnS és hxnR lókuszoktól kb. 40 kb távolságra térképezték, tudtuk, hogy a hxn6 lókusz azonosítása jelentősen elősegíti a NA katabolikus út genetikai hátterének feltárását. A hxn6 mutáns törzsbe A. nidulans génbank transzformálást hajtottunk végre és direkt szelekció alkalmazásával izoláltunk egy NA-at hasznosítani képes transzformáns törzset. A hxn6-ot komplementáló génbank plazmid menekítését követően szekvenálás segítségével az AN11187 génben azonosítottuk a hxn6 törzs fenotípusát okozó 
mutációt. Az AN11187 (későbbiekben hxnV) az NDC1 klasztertől mintegy 40 kb távolságra helyezkedik el. A hxn6 egy G1171A nunkleotid cserét hordoz, amely a kódolt fehérjében W296STOP AS cserét okozva láncterminációt eredményez. Ezt követően megvizsgáltuk a $h x n V$, valamint az ezzel szomszédos AN9159, AN11172, AN9161, AN9162 és AN9163 gének kifejeződését qRT-PCR segítségével $h x n R^{+}$és $h x n R \Delta$ törzsekben nem indukált és indukált (1 mM 6-NA-val történő indukció) körülmények között. A hxnV, az AN11172 és az AN9161 gének koregulációt mutattak az NDC1 génekkel (kifejeződésük HxnR és NA származék függést mutatott), mely alapján igazoltuk, hogy ezek a gének a NA katabolikus útvonalban szerepelnek. Az AN11172 és AN9161 géneket $h x n W$-nek és $h x n X$-nek neveztük el. A NA lebontási útvonal génjeiként azonosított $h x n V, h x n W$ és $h x n X$ gének az NDC1-től 40 kb távolságra a VI-os kromoszómán egy újabb klasztert alkotnak, amelyet NDC2-nek neveztünk el.

Korábbi in silico vizsgálataink alapján megállapítottuk, hogy számos gombarendben megtalálhatóak az NDC1 gének ortológjai. A NA katabolikus génklaszterek evolválódásának megismeréséhez egy kiterjedt in silico analízist végeztünk el közel 200 Pezizomycotina genomon szinténiát figyelembe vevő ortológkeresési eljárással a JGI Fungal Genome Portal adatbázisát használva. Érdekes módon a legtöbb gombafajban az NDC1 és NDC2 génjei egyetlen klaszterbe szerveződnek. A génsorrend vizsgálatakor megfigyeltük, hogy bizonyos gének génpárokba rendeződve erős konzerváltságot mutatnak. A génpárokat alkotó gének közül kettő, az I. kromoszómán egymás mellett elhelyezkedő AN6518 és AN10833 gének számunkra ismeretlenek voltak.

A két újonnan felfedezett gén (AN6518 és AN10833, a későbbiekben hxnM és $h x n N$ ) esetében is transzkriptum analízissel vizsgáltuk a génkifejeződés HxnR és NA származékok általi regulációját. Ez alapján a hxnM és hxnN gének is a NA katabolikus úthoz kapcsolhatóak. A két gén által alkotott klasztert NDC3-nak neveztük el.

Az NDC2-be és NDC3-ba tartozó gének cDNS szekvenciáinak kísérletes úton történő azonosítása során fényt derítettünk arra, hogy az AspGD adatbázisban szereplő intronok a $h x n V$ gén esetén nem helytállóak.

Az újonnan felfedezett két klaszterbe tartozó gének funkciójának megismeréséhez in silico elemzést végeztünk el, melynek eredményei alapján a következőket kaptuk:

- A HxnV valószínűleg egy FAD-függő fenol-monooxigenáz, amelynek szubsztrátja feltehetően a 2,5-dihidroxipiridin (2,5-DP).

- A HxnX egy N-terminális FAD-kötő doménnel rendelkező fehérje, mely monooxigenázokkal mutat homológiát, szubsztrátja pedig valószínüleg a 6-NA és a 2,5DP köztesterméket hozza létre. 
- A HxnW fehérje vizsgálataink alapján rövid láncú dehidrogenáz/reduktáz (SDR) szupercsalád tagjaival, oxidoreduktázokkal és $\mathrm{NAD}(\mathrm{P})$-kötő fehérjékkel mutat homológiát. Feltételezhetően vagy ketoreduktázként müködik, vagy dekarboxilációt végez a NA lebontás valamely aromás köztestermékén.

- A HxnM valószínúleg egy amido-hidroláz, amely a NA lebontás egy telített piridingyürüvel rendelkező köztestermékét hasítja fel egy szén és egy nitrogén molekula között.

- A HxnN pedig egy amidáz, amely valószínủleg lehasítja egy felnyílt gyürüs szerkezetü köztestermék amid csoportját, mely ezt követően nitrogénforrásként hasznosulhat.

Korábbi eredményeink alapján feltételezzük, hogy a $h x n S$, hxnT és $h x n Y$ gének a lebontási útvonal kezdeti lépéseiben játszanak szerepet. Ennek bizonyítására hxnShxnTA,

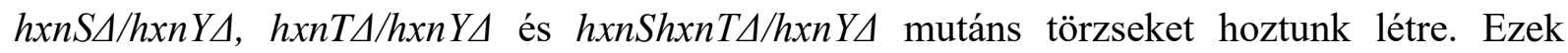
különböző nitrogénforrásokon végzett növekedési vizsgálatai során azt tapasztaltuk, hogy a hxnShxnTA és hxnShxnTA/hxnYA törzsek nitrogénforrásként 6-NA-at tartalmazó táptalajon a vad típushoz képest sokkal erősebb növekedést mutattak. Erre a meglepő fenotípusra magyarázat lehet, hogy a hxnShxnTA dupla mutáns előállítását egy közös szubsztitúciós kazetta transzformálásával végeztük, így ez a törzs nem tartalmazza a $h x n S$ és $h x n T$ gének közös promóter régióját. Az elmélet bizonyítására létrehoztunk egy olyan mutáns törzset, amelyben a promóter régiót nem érintette a deléció, azonban 6-NA nitrogénforráson ez a törzs is ugyanolyan erős növekedést mutatott, mint a promótert nem tartalmazó mutáns. A fenotípus magyarázatának megismeréséhez további vizsgálatok szükségesek.

A lebontás folyamatának megértéséhez az NDC2 (hxn $V$, hxnW és hxnX) és NDC3 ( $h x n M$ és $h x n N$ ) klaszterbe tartozó génekre nézve deléciós mutánsokat hoztunk létre, és növekedési képességüket vizsgáltuk különböző nitrogénforrásokon. Az Allp-lal és $100 \mu \mathrm{M}$ NA-val, vagy 6-NA-val kiegészített Hx diagnosztikus táptalajon végzett növekedési tesztek alapján, ahol a Hx hasznosítását egyedül a HxnS enzim végzi, megállapítottuk, hogy a HxnM és a HxnN a katabolikus útvonal valódi inducerének (mely nem a NA, vagy a 6-NA) termelődését követő lépésekért felelősek, míg a HxnV, HxnW és HxnX a valódi inducertől „upstream" vesznek részt a NA lebontásában. Amikor a NA-at és 6-NA-at nitrogénforrásként alkalmaztuk a $h x n V \Delta$, a $h x n X \Delta$ és a $h x n M \Delta$ mutánsok közül egyik sem volt képes nöni, a $h x n W \Delta$ mutáns pedig „leaky” növekedést mutatott. A $h x n V \Delta$ és a $h x n X \Delta$ törzsekben halmozódó köztes termékek vagy toxikus hatásúak, vagy gátolják a konstitutív transzkripciós faktort. Mindezeket figyelembe véve valószínűsíthetjük, hogy a HxnV és 


\section{HxnX az útvonal azonos ágán müködhetnek és részt vesznek a valódi inducer képzésében,}

a HxnW az alternatív útvonalon müködhet, a HxnM pedig a lebontási út downstream, elágazás nélküli ágán játszik szerepet a NA lebontásának folyamatában. A hxnNA törzs esetében tapasztalt redukált növekedés a NA és 6-NA nitrogénforráson, arra utalt, hogy nem a HxnN az egyedüli amidáz a katabolikus út végén, amely az amid csoport lehasításáért felel.

Annak érdekében, hogy a lebontási út génjeinek funkcióját az egyes mutánsokban az enzimműködés hiányában felhalmozódó metabolitokon keresztül vizsgálhassuk, biztosítanunk kellett az útvonalgének expresszióját a valódi inducer termelődésétől függetlenítve. Ezt egy konstitutív $h x n R\left(h x n R^{c}\right)$ allél kifejeztetésével tudtuk biztosítani, ezért minden $h x n$ deléciós mutánst $h x n R^{c} 7$ háttérbe kereszteztünk és vizsgáltuk a nitrogénforrás hasznosítási képességüket, valamint metabolit profiljukat. A HxnR folyamatos kifejeződése és a HxnS enzim aktivitása miatt azt vártuk, hogy minden mutáns nőni fog, ha az Allp-lal kiegészített $\mathrm{Hx}$ táptalajhoz NA-at vagy annak downstream származékait adagoljuk indukáló szer mennyiségben. Érdekes módon az 1 mM NA-val, vagy 6-NA-val kiegészített diagnosztikus Hx táptalajon a $h x n V \Delta h x n R^{c} 7$ törzs nem volt képes nőni, a $h x n W \Delta h x n R^{c} 7$ pedig redukált növekedést mutatott, ugyanakkor $100 \mu \mathrm{M}$ mennyiségben adagolva a NA-at, vagy 6-NA-at ezek a mutánsok a vad típusú törzzsel megegyező mértékü növekedést mutattak. A jelenség oka a köztes metabolit konstitutív háttér miatti túlzott felhalmozódása lehet, mely feltehetőleg toxikus a törzs számára, vagy inaktiválja a transzkripciós faktort. A $h x n X \Delta$ és $h x n M \Delta$ mutánsoknál is megfigyeltünk az előzőekhez hasonló, de kissebb mértékü toxicitást.

A $h x n V \Delta h x n R^{c} 7$ törzset urea nitrogénforrás mellett adagolt $10 \mathrm{mM}$ NA-on, vagy 10 mM 6-NA-on tenyésztve kék színű pigmentképződést figyeltünk meg a telep körül a táptalajban. Ehhez hasonló jelenséget baktériumok esetében (Bacillus és Pseudomonas fajokban) már leírtak és úgy gondolják, hogy a bakteriális kék pigment nem-enzimatikus úton képződő azakinon, amely telítetlen tri-hidroxilált piridin származékból képződik. Jelenleg zajlanak a $P$. putida és az $A$. nidulans esetében termelődő kék pigmentek összehasonlítására és azonosítására irányuló GC-MS vizsgálatok.

A NA katabolikus útvonal feltárásának keretén belül kíváncsiak voltunk arra is, hogy az egyes katabolikus lépések milyen intracelluláris kompartmentben zajlanak. Az útvonal enzimek lokalizációjának vizsgálata céljából in silico lokalizációs szignál keresést követően létrehoztuk és vizsgáltuk a GFP fúziós HxnV és HxnX fehérjék intracelluláris kompartmentalizációját. A HxnV feltételezhetően a citoplazmában, vagy valamely membránnal körülhatárolt kompartmentben, a HxnX pedig a peroxiszómákban lokalizálódik. 
GC-MS és HPLC-MS vizsgálatokat indítottunk el a NA katabolikus út metabolitjainak azonosítása céljából. A vizsgálatok során a konstitutív $h x n R^{c}$ háttérbe juttatott szimpla deléciós törzseket ( $h x n S \Delta, h x n T \Delta, h x n Y \Delta, h x n V, h x n X, h x n W$ és $h x n M)$, valamint a keresztezésükkel

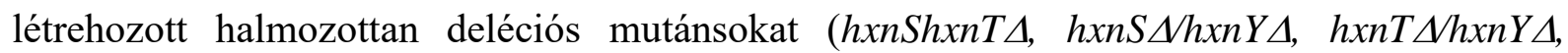

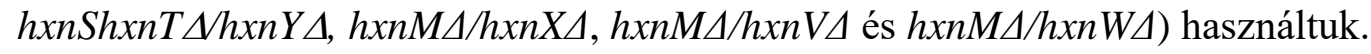

Az eddigi GC-MS és HPLC-MS eredményeink összhangban állnak a növekedési tesztek eredményeivel. A $h x n V \Delta, h x n X \Delta, h x n W \Delta$ és $h x n M \Delta$ szimpla és $h x n M \Delta h x n X \Delta, h x n M \Delta h x n V \Delta$ és $h x n M \Delta h x n W \Delta$ dupla mutáns törzsek vizsgálata megerösítette az alternatív útvonal létezését. Metabolit profilja alapján mind a három dupla mutáns a szimpla hxnMA törzzsel klasztereződött, ami arra utal, hogy a $h x n V$, $h x n X$, vagy $h x n W$ gének hiánya önmagában nem gátolja a lebontási útvonalat, a hxnM gén viszont már az útvonal közös szakaszán játszik szerepet, így a lebontás a dupla mutánsok esetében is itt akad el.

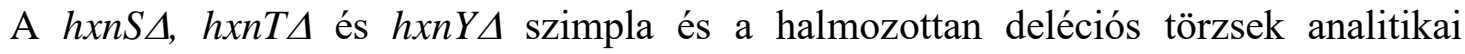
vizsgálatainak eredményei szintén támogatták az alternatív út létezését a NA katabolikus folyamatban. Eredményeink alapján az alternatív útvonalak egyik ágán a HxnS után előbb a HxnY, majd a HxnT következik, a másik ágon pedig a HxnW müködik. A deléciós törzsekben vizsgáltuk, hogy milyen köztes metabolitok halmozódnak fel a NA-on, vagy 6-NA-on történő inkubálás során. Azt figyeltük meg, hogy a nagy mennyiségben felhalmozódó metabolitok egynél több törzsben voltak megfigyelhetők, kivéve a 2,5-DP és egy $131 \mathrm{~g} / \mathrm{mol}$ molekulasúlyú vegyület esetén. A 2,5-DP felhalmozódást kizárólag a $h x n V \Delta h x n R^{c} 7$ törzsben tapasztaltunk, mely alapján valószínűsíthetjük, hogy a HxnV enzim szubsztrátja a 2,5-DP. A $131 \mathrm{~g} / \mathrm{mol}$ molekulkasúlyú vegyület kizárólag a $h x n W \Delta h x n R^{c} 7$ törzs esetében halmozódott fel. A vegyület szerkezeti azonosítására irányuló elemzések alapján ez a metabolit valószínüsíthetően az

\section{1,2,3,6-tetrahidro-piridin-2,3,6-triol, mely a HxnW szubsztrátja lehet.}

Eredményeink jelentősen hozzájárultak a NA katabolikus út feltárásához, de az útvonal teljes felderítése további kísérleteket igényel. Elképzelésünk szerint a $h x n S, h x n T, h x n Y, h x n V$, $h x n W, h x n X, h x n M$ és $h x n N$ deléciókra nézve halmozottan deléciós mutánsok létrehozása minden kombinációban megoldást fog nyújtani az eddig még nem tisztázott katabolikus lépéseket felderítésére. 


\section{SUMMARY}

Although many microorganisms are able to utilize nicotinic acid (NA) as a sole nitrogen source, the degradation process was studied only in prokaryotes so far. The catabolic process is completely unknown in eukaryotes although it is known that some organisms, such as Aspergillus nidulans are able to utilize NA as the sole nitrogen source. Very few data were available about the NA catabolism at the beginning of our research. The enzyme acting in the first step of the NA utilization (purine hydroxylase II/PHII - later HxnS) was characterized and NA non-utilizer mutants were isolated. Interestingly, the identification of PHII was connected to the study of the purine utilization pathway. One of the key enzyme of purine breakdown is the purine hydroxylase I (PHI, encoded by $h x A$ ) that can convert hypoxanthine (Hx) to xanthine and xanthine to uric acid. During the study of PHI functions the PHII enzyme was discovered. In PHI loss-of-function mutants $\mathrm{Hx}$ was successfully utilized in case the medium was supplemented with low amount (100 $\mu \mathrm{M}-1 \mathrm{mM})$ of NA or 6-hydroxynicotinic acid (6-NA). It was due to the production of PHII, which is able to convert Hx to xanthine, but is not able to convert xanthine to uric acid. The xanthine $\rightarrow$ uric acid transformation was found to be carried out by an alternative enzyme, an $\alpha$-ketoglutarate-dependent xanthine dehidrogenase (XanA). The following studies revealed that besides Hx, PHII can also use NA as a substrate and can convert it to 6-NA. Several NA non-utilizer mutants were isolated in the 1970's and classified into linkage groups. Mutants of the $h x n S$ group could not utilize NA, but could utilize 6-NA as a sole nitrogen source. Another group named $h x n R$ were composed of mutants, that could utilize neither NA, nor 6-NA and could not grow on Hx media supplemented with the PHI inhibitor Allopurinol (Allp) and inducer amount of NA. They were thought to be regulatory mutants. Mutants of a third group named aplA could utilize NA and 6-NA more efficiently than the wild type strain and were able to grow on Hx media supplemented with Allp. Since NA induction was unnecessary in these strains to perform PHII activity, aplA mutants were thought to be regulatory mutants. Other linkage groups were also defined in the proximity of the $h x n S, h x n R$ and aplA linkage groups but those results were never published and the strains with one exception (hxnל) were lost with time.

In the 2000's our group started to reveal the first NA degradation pathway in the model organism A. nidulans by identifying the PHII encoding $h x n S$ gene as AN9178 and the transcription factor coding gene $h x n R$ as AN11197. We also revealed that aplA is the same locus as $h x n R$, and aplA mutations refer to gain-of-function mutations, which lead to constitutive HxnR. We studied the regulation of $h x n S$ and $h x n R$ together with their flanking 
genes ( $h x n T, h x n Y, h x n P$ and $h x n Z)$ and revealed a co-regulated cluster of six genes that are inducible by NA or 6-NA and their expression is depended on the transcription factor HxnR and transcription co-regulator AreA. We named this cluster NDC1. Through the obtaining of gene deletions for all $h x n$ genes, we studied their role in NA utilization. We concluded that $h x n T$ and $h x n Y$ code for enzymes operating on an alternative route in the pathway, $h x n P$ and $h x n Z$ code for transporters and $h x n S$ codes for PHII, which is involved not only in NA $\rightarrow 6-\mathrm{NA}$ conversion but in the further conversion of the 6-NA. We found out, that 2,5-dihydroxypyridine (2,5-DP) is an intermediate compound of the pathway and may serve as inducer. We showed that other genes outside of the cluster NDC1 are involved in the NA utilization.

In order to find out what these unknown genes are, we started to examine the only extant mutant from the 1970's, hxn6, which is not able to utilize NA or 6-NA as a nitrogen source and was mapped outside of the NDC1 cluster, approximately $40 \mathrm{~kb}$ distance from the $h x n S$ and $h x n R$. We knew that the identification of the hxn6 locus would be very helpful for unravelling the genetic background of the NA catabolic pathway. By the transformation of the hxn6 mutant with the plasmid gene bank of $A$. nidulans and selection for NA utilizing transformants followed by plasmid rescue and sequence analysis, we identified one supressor gene of hxn AN11187. The AN11187 (later $h x n V$ ) is located approximately $40 \mathrm{~kb}$ from NDC1. The hxn6 allele contains a G1171A nucleotide change that causes a W296STOP (amber) amino acid change in the protein resulting in chain termination. Subsequently we analysed the expression of the flanking genes of $h x n V$ (AN9159, AN11172, AN9161, AN9162 and AN9163) by qRTPCR in $h x n R^{+}$and $h x n R \Delta$ strains under non-inductive and inductive (induced with $1 \mathrm{mM} 6-\mathrm{NA}$ ) conditions. hxnV, AN11172 and AN9161 showed co-regulation with the NDC1 genes (their expression depends on HxnR and NA derivatives) so these genes could be connected to the NA catabolic process. We named AN11172 hxnW and AN9161 hxnX and the gene cluster formed by them together with $h x n V$ was named NDC2.

In order to understand the evolution of the NA catabolic gene clusters we carried out an extensive in silico analysis of the HxnS, HxnR, HxnT, HxnY, HxnZ, HxnP, HxnX, HxnW and HxnV orthologs identified in nearly 200 Pezizomycotina genomes on JGI Fungal Genome Portal database using gene onthology BLAST search with synteny analysis. Remarkably, we found that the NDC1 and NDC2 genes are organized into a single cluster in most fungal species. We noticed the conservation of certain gene pairs through the Pezizomycotina. hxnS was frequently coupled with $h x n T, h x n P$ with $h x n Y, h x n W$ with AN6518 and $h x n V$ with AN10833. Two of these genes, AN6518 and AN10833, were unknown for us. These genes are located next to each other on Chromosome I in the A. nidulans genome, which together with their 
conserved association with $h x n$ genes through the Pezizomycotina raised the possibility of their role in NA utilization.

Transcript analysis of these two genes showed that they are co-regulated with the $h x n$ genes, therefore AN6518 and AN10833 (under names $h x n M$ and $h x n N$ ) can be regarded as new members of the NA utilization route, which form a third cluster, named NDC3.

We constructed the protein models of the NDC2 and NDC3 genes through sequencing their cDNAs and found out that protein model of $h x n V$ in AspGD database is wrong.

With the protein sequence of NDC2 and NDC3 genes we carried out in silico analysis, and hypothesized their possible function in the NA utilization. According to the in silico analysis:

- HxnV is probably a FAD-binding phenol monooxygenase and its substrate is supposedly 2,5-DP.

- HxnX has an N-terminal FAD-binding domain and it shows homology with monooxigenases. It may catalyze the hydroxylation of 6-NA to 2,5-DP.

- HxnW shows homology with members of the short-chain dehydrogenase/reductase (SDR) superfamily, oxidoreductases and NAD(P)-binding proteins. It is believed that it either acts as a ketoreductase or it performs decarboxylation on an aromatic intermediate compound of the degradation pathway.

- HxnM is probably an amido-hydrolase which cleaves between a carbon and a nitrogen molecule in an intermediate of NA degradation pathway having a saturated pyridine ring.

- HxnN is an amidase, which supposedly cleaves the amid group from a compound with opened pyridine ring, that can be utilized as a nitrogen source thereafter.

Based on our previous results we hypothesized that $h x n S, h x n T$ and $h x n Y$ genes play role in the initial steps of the degradation pathway. In order to support this idea, we created

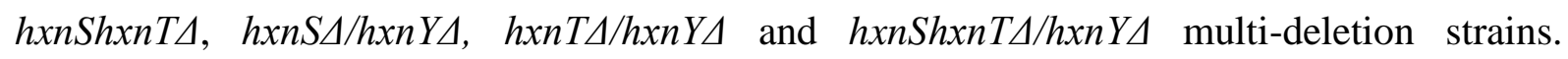
Remarkably, hxnShxnTA and hxnShxnTA/hxnYA mutants showed more efficient 6-NA utilization properties than the wild type control. The explanation for this surprising phenomenon can be the lack of the shared promoter region of $h x n S$ and $h x n T$, since we used a single substitution cassette for the creation of the hxnShxnTA double mutant in one step. In order to prove this theory, we created a double mutant, in which the deletion did not affect the 
promoter region. The new double mutant (with intact $h x n S / h x n T$ promoter) showed the same improved 6-NA utilization phenotype as the old double mutants (with deleted hxnS/hxnT promoter). Therefore, the phenotype is independent from the presence or absence of the shared promoter region. To be able to explain this phenotype, further studies are required.

In order to study the function of the NDC2 and NDC3 gene products, we obtained gene deletion mutants for $h x n V, h x n W, h x n X, h x n M$ and $h x n N$ and tested their nitrogen source utilization abilities. Using Hx diagnostic media (Hx nitrogen source supplemented with Allp and $100 \mu \mathrm{M}$ NA or 6-NA), where only HxnS can catalyze the conversion of Hx to xanthine, we revealed that HxnM and HxnN operates downstream to the true metabolic inducer of the pathway (which is not NA or 6-NA) while HxnV, HxnW and HxnX operates upstream to the true inducer. When we used NA or 6-NA as nitrogen source $h x n V A, h x n X \Delta$ and $h x n M \Delta$ strains were not able to grow and $h x n W \Delta$ mutant together with $h x n N \Delta$ showed leaky phenotype. The accumulation of intermediates in $h x n V \Delta$ and $h x n X \Delta$ results in either toxicity or inhibition of the constitutive transcription factor. Taken together these data, we suppose that HxnV and HxnX operate on one branch of the route, and are implicated in the formation of the true inducer, $\mathrm{HxnW}$ operates on the alternative route upstream to the true inducer, while HxnM operates on a non-splitted route downstream to the true inducer. The leaky phenotype of $h x n N \Delta$ foretells that $\mathrm{HxnN}$ is not the only amidase responsible for the cleavage of the amide group from the supposedly opened pyridine ring.

Since we don't know the true inducer compound (we know only that it derives from the metabolization of NA, 6-NA or 2,5-DP), we could not activate the gene expression of the $h x n$ genes in those deletion mutants, which lack enzymes upstream to the true inducer. In order to circumvent the problem caused by the unknown true inducer, we introduced a constitutive $h x n R$ allele $\left(h x n R^{c}\right)$ into the $h x n V \Delta, h x n X \Delta, h x n W \Delta, h x n M \Delta$ and $h x n N \Delta$ strains by genetic crossing. With the $h x n R^{c}$ background the expression of the $h x n$ genes is independent from the production of the true inducer metabolite. As we expected, all these mutants were able to grow on Hx+Allp medium without NA-derived inducer. However, when the $\mathrm{Hx}$ diagnostic media was supplemented with $1 \mathrm{mM}$ NA or 6-NA the $h x n V \Delta h x n R^{c}$ mutant could not grow at all and the $h x n W \Delta h x n R^{c}$ mutant showed a reduced growth. Interestingly, when the amount of inducer was decreased to $100 \mu \mathrm{M}$, both $h x n V \Delta h x n R^{c} 7$ and $h x n W \Delta h x n R^{c} 7$ mutants could grow as much as the wild type. The explanation of this phenomenon is the toxic or HxnR inactivating nature of the compound accumulated in the constitutive hxnVA and hxnWA mutants. The hxnXA and hxnMA mutants also showed signs of toxicity (or inhibition of constitutive HxnR) but with lower extent than that was observed in $h x n V \Delta h x n R^{c} 7$ and $h x n W \Delta h x n R^{c} 7$. 
We noticed that the $h x n V \Delta h x n R^{c}$ mutant produced a blue pigment on urea nitrogen source supplemented with $10 \mathrm{mM}$ NA or $10 \mathrm{mM}$ 6-NA. This phenomenon is similar to that observed in prokaryotes (Bacillus spp. and Pseudomonas spp.). The bacterial blue pigment thought to be an azaquinone compound formed by a non-enzymatic conversion of an unsaturated trihydroxylated pyridine derivative. In order to identify and compare the fungal blue pigment to that of the prokaryotic, we are currently performing GC-MS analysis on samples derived from $A$. nidulans $h x n V \Delta h x n R^{c}$ mutant and $P$. putida NicX mutant.

We aimed to study the intracellular compartmentalization of the NA catabolic route by expressing $g f p$-fused $h x n$ genes in the appropriate $h x n$ deletion strains. So far we studied the intracellular localization of $\mathrm{HxnV}$ and $\mathrm{HxnX}$. According to the in silico localization signal search HxnV was expected in the cytoplasm, while HxnX in the peroxisomes. In case of $\mathbf{H x n V}$ GFP we could not exclude the possibility of compartmentalization. Further studies on the HxnV-GFP expressing strain is needed. In case of GFP-HxnX we clearly proved the peroxisomal localization of the fused protein, by showing the co-localization of GFP-HxnX with PTS-tagged mRFP.

In order to unravel the chemical structure of the pathway related compounds, in collaboration with a chemist expert Dr. Mónika Varga (operating at the analytical work station of the Department of Microbiology at USz) we performed GC-MS and HPLC-MS analyses on samples obtained from cultures of constitutive single and multiple-deletion mutants incubated with NA or 6-NA substrates after pregrowth. The multiple deletion mutants were created by genetic crosses ( $h x n M \Delta / h x n X \Delta, h x n M \Delta / h x n V \Delta, h x n M \Delta / h x n W \Delta)$.

Although the preliminary GC-MS and HPLC-MS experiments has already provided valuable data for the uncovering of certain features of the NA catabolic pathway, the identification of each step of the pathway remains a challenging and robust work done in the near future.

The primary component analysis of the metabolites obtained from the $h x n X \Delta, h x n W \Delta$,

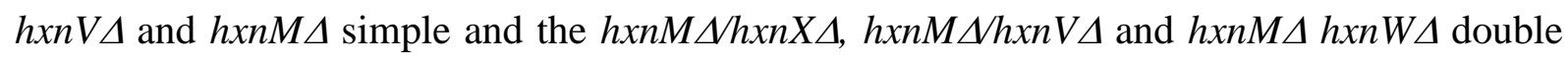
deletion mutants confirmed the existance of the alternative route as each double mutant clusterized with the simple $h x n M \Delta$ mutant, which indicates that the lack of $h x n V, h x n X$ or $h x n W$ is not enough to terminate the degradation.

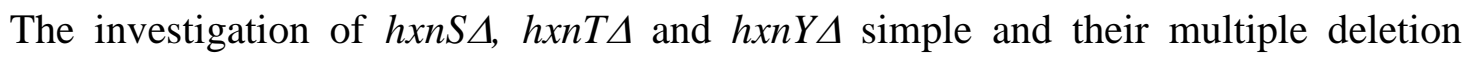
mutants supported that the NA degradation pathway of $A$. nidulans splits to alternative routes.

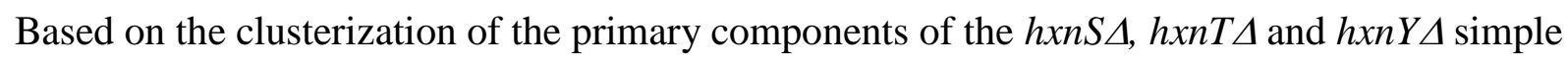


and their multiple deletion mutants we can propose that HxnS operates upstream to HxnY and HxnT operates downstream to $\mathrm{HxnY}$ on a route, which is alternative to that involving $\mathrm{HxnW}$. We observed that most of the metabolites accumulated in more than one mutants, only 2,5-DP and an unidentified compound with $131 \mathrm{~g} / \mathrm{mol}$ molecule weight (Mw131) could be found exclusively in single mutants. 2,5-DP was exclusively found in the hxnVA strain, that clearly suggests that the 2,5-DP is the substrate of $\mathbf{H x n V}$. The Mw131 compound was exclusively found in the hxnWA strain, which indicates that Mw131 is the substrate of HxnW. We proposed that Mw131 is a 1,2,3,6-tetrahydropyridine-2,3,6-triol, which is a more saturated derivative of the intermediate 2,3,6-trihydroxypyridine compound of the prokaryotic routes (in Bacillus and Pseudomonas spp.).

In summary, our results significantly contributed to the understanding of NA catabolic pathway, and proved that the eukaryotic route is different from those found in prokaryotes in many aspects. They are the split of the pathway to alternative routes and production of intermediate compounds that were not detected in the prokaryotic routes. Despite of our achievements, further research is needed for the complete understanding of each step of the pathway. 


\section{IRODALOMJEGYZÉK}

Al-Mohaissen MA, Pun SC \& Frohlich JJ (2010) Niacin: from mechanisms of action to therapeutic uses. Mini Rev Med Chem 10: 204-217.

Alhapel A, Darley DJ, Wagener N, Eckel E, Elsner N \& Pierik AJ (2006) Molecular and functional analysis of nicotinate catabolism in Eubacterium barkeri. Proc Natl Acad Sci U S A 103: 12341-12346.

Ámon J (2018) Az első eukarióta nikotinsav hasznosítási útvonal felderítése, szabályozása és az útvonal enzimeinek vizsgálata Aspergillus nidulans modellszervezetben $\mathrm{PhD}$ értekezés Thesis, University of Szeged, Szeged.

Ámon J, Fernandez-Martin R, Bokor E és mtsai. (2017) A eukaryotic nicotinate-inducible gene cluster: convergent evolution in fungi and bacteria. Open Biol 7.

Antal Z, Manczinger L \& Ferenczy L (1997) Transformation of a mycoparasitic Trichoderma harzianum strain with the $\operatorname{argB}$ gene of Aspergillus nidulans. Biotechnology Techniques 11: $205-208$.

Behrman EJ \& Stanier RY (1957) The bacterial oxidation of nicotinic acid. J Biol Chem 228: 923-945.

Bennett JW \& Papa KE (1988) The aflatoxigenic Aspergillus species. Advances in Plant Pathology, Vol. 6 ed.^eds.), p.^pp. 263-280.

Bhattacharjee N, Feliks M, Shaik MM \& Field MJ (2017) Catalytic Mechanism of Peptidoglycan Deacetylase: A Computational Study. J Phys Chem B 121: 89-99.

Boyer JH \& Kruger S (1957) Azaquinones. I. Oxidation of Certain Hydroxy- and Aminopyridones1. Journal of the American Chemical Society 79: 3552-3554.

Coughlan MP, Mehra RK, Barber MJ \& Siegel LM (1984) Optical and electron paramagnetic resonance spectroscopic studies on purine hydroxylase II from Aspergillus nidulans. Arch Biochem Biophys 229: 596-603.

Enroth C (2003) High-resolution structure of phenol hydroxylase and correction of sequence errors. Acta Crystallogr D Biol Crystallogr 59: 1597-1602.

Ensign \& Rittenberg (1964) The Pathway of Nicotinic Acid Oxidation by a Bacillus Species. $J$ Biol Chem 239: 2285-2291.

Ensign JC \& Rittenberg SC (1963) A Crystalline Pigment Produced from 2-Hydroxypyridine by Arthrobacter Crystallopoietes N.Sp. Arch Mikrobiol 47: 137-153.

Ferenczy L, Kevei F \& Szegedi M (1975) Increased fusion frequency of Aspergillus nidulans protoplasts. Experientia 31: 50-52. 
Fetzner S (1998) Bacterial dehalogenation. Appl Microbiol Biotechnol 50: 633-657.

Fogarty WM (1994) Enzymes of the Genus Aspergillus. Aspergillus. Biotechnology Handbooks, Vol. vol 7. (Smith JE, ed.^eds.), p.^pp. Springer, Boston, MA.

Glatigny A \& Scazzocchio C (1995) Cloning and molecular characterization of $h x A$, the gene coding for the xanthine dehydrogenase (purine hydroxylase I) of Aspergillus nidulans. J Biol Chem 270: 3534-3550.

Goldman GH \& Kafer E (2004) Aspergillus nidulans as a model system to characterize the DNA damage response in eukaryotes. Fungal Genet Biol 41: 428-442.

Gurvitz A, Rottensteiner H, Kilpelainen SH és mtsai. (1997) The Saccharomyces cerevisiae peroxisomal 2,4-dienoyl-CoA reductase is encoded by the oleate-inducible gene SPS19. J Biol Chem 272: 22140-22147.

Hicks KA, Yuen ME, Zhen WF, Gerwig TJ, Story RW, Kopp MC \& Snider MJ (2016) Structural and Biochemical Characterization of 6-Hydroxynicotinic Acid 3Monooxygenase, A Novel Decarboxylative Hydroxylase Involved in Aerobic Nicotinate Degradation. Biochemistry 55: 3432-3446.

Holesova Z, Jakubkova M, Zavadiakova I, Zeman I, Tomaska L \& Nosek J (2011) Gentisate and 3-oxoadipate pathways in the yeast Candida parapsilosis: identification and functional analysis of the genes coding for 3-hydroxybenzoate 6-hydroxylase and 4hydroxybenzoate 1-hydroxylase. Microbiology 157: 2152-2163.

Ikeda M, Tsuji H, Nakamura S, Ichiyama A, Nishizuka Y \& Hayaishi O (1965) Studies on the Biosynthesis of Nicotinamide Adenine Dinucleotide. Ii. A Role of Picolinic Carboxylase in the Biosynthesis of Nicotinamide Adenine Dinucleotide from Tryptophan in Mammals. J Biol Chem 240: 1395-1401.

Jimenez JI, Canales A, Jimenez-Barbero J, Ginalski K, Rychlewski L, Garcia JL \& Diaz E (2008) Deciphering the genetic determinants for aerobic nicotinic acid degradation: the nic cluster from Pseudomonas putida KT2440. Proc Natl Acad Sci U S A 105: 1132911334.

Kavanagh KL, Jornvall H, Persson B \& Oppermann U (2008) Medium- and short-chain dehydrogenase/reductase gene and protein families : the SDR superfamily: functional and structural diversity within a family of metabolic and regulatory enzymes. Cell Mol Life Sci 65: 3895-3906.

Kelley LA, Mezulis S, Yates CM, Wass MN \& Sternberg MJ (2015) The Phyre2 web portal for protein modeling, prediction and analysis. Nat Protoc 10: 845-858. 
Kevei F \& Peberdy JF (1977) Interspecific Hybridization between Aspergillus nidulans and Aspergillus rugulosus by Fusion of Somatic Protoplasts. Journal of General Microbiology 102: 255-262.

Larionov A, Krause A \& Miller W (2005) A standard curve based method for relative real time PCR data processing. BMC Bioinformatics 6: 62.

Lewis NJ, Hurt P, Sealy-Lewis HM \& Scazzocchio C (1978) The genetic control of the molybdoflavoproteins in Aspergillus nidulans. IV. A comparison between purine hydroxylase I and II. Eur J Biochem 91: 311-316.

Liu X, Yuan Z, Adam Yuan Y, Lin J \& Wei D (2011) Biochemical and structural analysis of Gox2181, a new member of the SDR superfamily from Gluconobacter oxydans. Biochem Biophys Res Commun 415: 410-415.

MacKay D, Hathcock J \& Guarneri E (2012) Niacin: chemical forms, bioavailability, and health effects. Nutr Rev 70: 357-366.

Maniatis T, Sambrook J \& Fritsch EF (1982) Molecular cloning: A Laboratory Manual. Cold Spring Harbor Laboratory Press, Cold Spring Harbor, NY.

Mehra RK \& Coughlan MP (1989) Characterization of purine hydroxylase I from Aspergillus nidulans. J Gen Microbiol 135: 273-278.

Mileni M, Johnson DS, Wang Z és mtsai. (2008) Structure-guided inhibitor design for human FAAH by interspecies active site conversion. Proc Natl Acad Sci U S A 105: 1282012824.

Nakano H, Wieser M, Hurh B, Kawai T, Yoshida T, Yamane T \& Nagasawa T (1999) Purification, characterization and gene cloning of 6-hydroxynicotinate 3monooxygenase from Pseudomonas fluorescens TN5. Eur J Biochem 260: 120-126.

Nayak T, Szewczyk E, Oakley CE és mtsai. (2006) A versatile and efficient gene-targeting system for Aspergillus nidulans. Genetics 172: 1557-1566.

Osherov N \& May G (2000) Conidial germination in Aspergillus nidulans requires RAS signaling and protein synthesis. Genetics 155: 647-656.

Osmani SA \& Mirabito PM (2004) The early impact of genetics on our understanding of cell cycle regulation in Aspergillus nidulans. Fungal Genet Biol 41: 401-410.

Pelczar MJ \& Porter JR (1940) Utilization of Nicotinic Acid and Related Pyridine Compounds by the Proteus Group of Organisms. J Bacteriol 39: 429-435.

Pontecorvo G, Roper JA, Hemmons LM, Macdonald KD \& Bufton AW (1953) The genetics of Aspergillus nidulans. Adv Genet 5: 141-238. 
Said HM (2011) Intestinal absorption of water-soluble vitamins in health and disease. Biochem J 437: 357-372.

Scazzocchio C (1973) The genetic control of molybdoflavoproteins in Aspergillus nidulans. II. Use of NADH dehydrogenase activity associated with xanthine dehydrogenase to investigate substrate and product inductions. Mol Gen Genet 125: 147-155.

Scazzocchio C, Holl FB \& Foguelman AI (1973) The genetic control of molybdoflavoproteins in Aspergillus nidulans. Allopurinol-resistant mutants constitutive for xanthinedehydrogenase. Eur J Biochem 36: 428-445.

Schmid A, Dordick JS, Hauer B, Kiener A, Wubbolts M \& Witholt B (2001) Industrial biocatalysis today and tomorrow. Nature 409: 258-268.

Schroeder HW \& Kelton WH (1975) Production of sterigmatocystin by some species of the genus Aspergillus and its toxicity to chicken embryos. Appl Microbiol 30: 589-591.

Sealy-Lewis HM, Scazzocchio C \& Lee S (1978) A mutation defective in the xanthine alternative pathway of Aspergillus nidulans: its use to investigate the specificity of uaY mediated induction. Mol Gen Genet 164: 303-308.

Sealy-Lewis HM, Lycan D \& Scazzocchio C (1979) Product induction of purine hydroxylase II in Asperigillus nidulans. Mol Gen Genet 174: 105-106.

Shaik MM, Cendron L, Percudani R \& Zanotti G (2011) The structure of Helicobacter pylori HP0310 reveals an atypical peptidoglycan deacetylase. PLoS One 6: e19207.

Shi YW, Cui LF \& Yuan JM (2007) Gene cloning, expression, and substrate specificity of an imidase from the strain Pseudomonas putida YZ-26. Curr Microbiol 55: 61-64.

Shin S, Lee TH, Ha NC és mtsai. (2002) Structure of malonamidase E2 reveals a novel SercisSer-Lys catalytic triad in a new serine hydrolase fold that is prevalent in nature. EMBO J 21: 2509-2516.

Sugui JA, Kwon-Chung KJ, Juvvadi PR, Latge JP \& Steinbach WJ (2014) Aspergillus fumigatus and related species. Cold Spring Harb Perspect Med 5: a019786.

Tinschert A, Kiener A, Heinzmann K \& Tschech A (1997) Isolation of new 6-methylnicotinicacid-degrading bacteria, one of which catalyses the regioselective hydroxylation of nicotinic acid at position C2. Arch Microbiol 168: 355-361.

Wang SN, Xu P, Tang HZ és mtsai. (2004) Biodegradation and detoxification of nicotine in tobacco solid waste by a Pseudomonas sp. Biotechnol Lett 26: 1493-1496.

Ward OP, Qin WM, Dhanjoon J, Ye J \& Singh A (2005) Physiology and Biotechnology of Aspergillus. Adv Appl Microbiol 58C: 1-75. 
Yoshida T \& Nagasawa T (2000) Enzymatic functionalization of aromatic N-heterocycles: hydroxylation and carboxylation. J Biosci Bioeng 89: 111-118.

Yu JH, Hamari Z, Han KH, Seo JA, Reyes-Dominguez Y \& Scazzocchio C (2004) Doublejoint PCR: a PCR-based molecular tool for gene manipulations in filamentous fungi. Fungal Genet Biol 41: 973-981. 


\section{KÖSZÖNETNYILVÁNÍTÁS}

Elsősorban Prof. Dr. Vágvölgyi Csabának, a Szegedi Tudományegyetem Természettudományi és Informatikai Kar, Mikrobiológiai Tanszékének vezetőjének szeretném megköszönni a lehetőséget, hogy szakdolgozói, és $\mathrm{PhD}$ munkámat a tanszéken végezhessem.

Köszönettel tartozom témavezetőmnek, Dr. Hamari Zsuzsannának támogatásáért és a rengeteg segítségért amit az elmúlt 7 évben nyújtott számomra.

Köszönöm Dr. Karácsony Zoltánnak türelmét és segítségét szakdolgozói munkám során és $\mathrm{PhD}$ éveim kezdetetén, mely idő alatt laboratóriumi alapismereteimet elsajátíthattam. Köszönöm szépen Dr. Gácser Attilának és Dr. Németh Tibornak az évek során nyújtott segítségéért és hogy kérdéseimmel bármikor fordulhattam hozzájuk.

Külön köszönettel tartozom Ámon Juditnak a kísérleteim elvégzéséhez nyújtott segítségéért. Nagyon köszönöm Dr. Varga Mónikának az analitikai vizsgálatok elvégzéséhez nyújtott segítségét. Köszönöm Michel Flipphi-nek segítségét az in silico analízisekhez.

Köszönettel tartozom a 301-es labor valamennyi volt és jelenlegi dolgozójának, különösképpen Szenzenstein Juditnak, Papp Csabának, Dr. Grózer Zsuzsannának, Dr. Tóth Adélnak, Dr. Tóth Renátának, Csonka Katalinnak, Zajta Eriknek, Pál Sárának és Bohner Flórának, hogy bármikor fordulhattam hozzájuk segítségért és laboruk tagjaként tekintettek rám. Köszönettel tartozom Lele Máriának és Deákné Kulcsár Melindának, hogy technikai kérdéseimmel mindig fordulhattam hozzájuk, Lengyel Boglárkának és Csordás Anitának pedig a gazdasági ügyek intézéséért.

Szeretném továbbá megköszönni Tóth Eszternek, Kartali Tündének, Szebenyi Csillának, Dr. Nyilasi Ildikónak és Dr. Csernetics Árpádnak a barátságukat és támogatásukat. Köszönettel tartozom emellett barátaimnak, akik mindig támogattak.

Külön köszönöm Családomnak, elsősorban Szüleimnek az életem során nyújtott rengeteg szeretetet és támogatást, amely nélkül nem jutottam volna el idáig és nagyon köszönöm Páromnak, Baksa Zoltánnak a kitartó támagotást, és sok türelmet, mellyel nagyban hozzájárult dolgozatom elkészítéséhez.

Köszönettel tartozom a Mikrobiológiai Tanszék minden volt és jelenlegi dolgozójának, akik bármilyen formában segítettek dolgozatom elkészítéséhez.

Jelen kutatás az OTKA-K101218, NKFI-K16 119516, a GINOP-2.3.2-15-2016-00035 és a GINOP-2.3.3-15-2016-00006 pályázatok támogatásával valósulhatott meg. 


\section{MELLÉKLETEK}

\section{1. melléklet}

Felhasznált $\boldsymbol{A}$. nidulans törzsek

\begin{tabular}{|c|c|c|c|}
\hline Törzs & Genotípus & Felhasználás & Hivatkozás \\
\hline HZS.106 & $\begin{array}{l}\text { hxnSA::zeo, hxA }:: z e o, \\
\text { pyrG89, pantoB100, biAl, } \\
\text { veAl, pyr4 in trans }\end{array}$ & szülői törzs keresztezéshez & (Ámon, 2018) \\
\hline HZS.120 & riboB2, pabaA1, veAl & $\begin{array}{l}\text { vad típusú kontroll a } \\
\text { növekedési tesztekhez }\end{array}$ & $\begin{array}{l}\text { (Hamari és mtsai., } \\
\text { 2009) }\end{array}$ \\
\hline HZS.123 & $\begin{array}{l}\text { anAl, riboB2, pabaA1, } \\
\text { veAl }\end{array}$ & szülői törzs keresztezéshez & (Ámon, 2018) \\
\hline HZS.125 & pyrG89; yA2, veAl & szülői törzs keresztezéshez & jelen munka \\
\hline HZS.135 & $h x B 20, b i A l, v e A 1$ & növekedési tesztek & $\begin{array}{l}\text { (Ámon és mtsai., } \\
\text { 2017) }\end{array}$ \\
\hline HZS.136 & $\begin{array}{l}\text { hxnRA::zeo; pantoB100, } \\
\text { veAl }\end{array}$ & $\begin{array}{l}\text { kontroll törzs GC-MS } \\
\text { analízishez }\end{array}$ & $\begin{array}{l}\text { (Ámon és mtsai., } \\
\text { 2017) }\end{array}$ \\
\hline HZS.145 & veAl & $\begin{array}{l}\text { vad típusú kontroll a } \\
\text { Southern-hibridizációk } \\
\text { során }\end{array}$ & $\begin{array}{l}\text { (Ámon és mtsai., } \\
\text { 2017) }\end{array}$ \\
\hline HZS.220 & $\begin{array}{l}\text { hxnPA::riboB }{ }^{+}, \operatorname{riboB} 2, \\
\text { hxnR80, pyroA4, } \\
\text { nkuA }:: \arg ^{+}, \text {veA1 }\end{array}$ & növekedési tesztek & $\begin{array}{l}\text { (Ámon és mtsai., } \\
\text { 2017) }\end{array}$ \\
\hline HZS.222 & $\begin{array}{l}\text { hxnTA::pabaA }{ }^{+} \text {; riboB2 } \\
\text { pabaAl, veA1 }\end{array}$ & $\begin{array}{l}\text { szülöi törzs } \\
\text { keresztezéshez, } \\
\text { növekedési tesztek }\end{array}$ & (Ámon, 2018) \\
\hline HZS.223 & $\begin{array}{l}\text { hxnYA::riboB }{ }^{+}, \text {pabaAl, } \\
\text { riboB2, veA1 }\end{array}$ & $\begin{array}{l}\text { többszörösen deléciós } \\
\text { mutánsok létrehozása }\end{array}$ & (Ámon, 2018) \\
\hline HZS.250 & $h x n S \Delta:: z e o, b i A 1$, veAl & $\begin{array}{l}\text { kontroll törzs GC- } \\
\text { MS/HPLC-MS analízishez }\end{array}$ & $\begin{array}{l}\text { jelen munka (utód a } \\
\text { HZS.106×HZS.122 } \\
\text { keresztezésből) }\end{array}$ \\
\hline HZS.251 & $\begin{array}{l}\text { riboB2, biAl, pabaAl, } \\
\text { veAl }\end{array}$ & $\begin{array}{l}\text { transzformációs recipiens } \\
\text { törzs deléciós törzsek } \\
\text { létrehozásához }\end{array}$ & $\begin{array}{l}\text { jelen munka (utód a } \\
\text { HZS.106×HZS.122 } \\
\text { keresztezésből) }\end{array}$ \\
\hline HZS.257 & hxn6, pyrG89, yA2, veAl & $\begin{array}{l}\text { recipiens törzs a génbank } \\
\text { transzformáláshoz }\end{array}$ & $\begin{array}{l}\text { jelen munka (utód a } \\
\text { CS308xHZS.125 } \\
\text { keresztezésből) }\end{array}$ \\
\hline HZS.267 & riboB2, pantoB100, veA1 & $\begin{array}{l}\text { transzformációs recipiens } \\
\text { törzs deléciós törzsek } \\
\text { létrehozásához }\end{array}$ & $\begin{array}{l}\text { jelen munka (utód a } \\
\text { HZS.308×HZS.227 } \\
\text { keresztezésböl) }\end{array}$ \\
\hline HZS.287 & $\begin{array}{l}\text { hxnNA::riboB }{ }^{+}, \text {biAl, } \\
\text { pabaAl, (riboB2), veAl }\end{array}$ & deléciós mutáns & $\begin{array}{l}\text { jelen munka } \\
(\mathrm{HZS} .251 \mathrm{trf} / 5)\end{array}$ \\
\hline HZS.288 & $\begin{array}{l}\text { hxnNA::ribo } B^{+}, \text {pyroA4, } \\
\text { nkuAA::argB } B^{+},(\text {riboB2 }), \\
\text { veAl }\end{array}$ & növekedési tesztek & $\begin{array}{l}\text { jelen munka (TN02 } \\
\text { A21 trf/1) }\end{array}$ \\
\hline HZS.289 & $\begin{array}{l}\text { hxnNA::riboB }{ }^{+}, \text {pyroA4, } \\
\text { nkuAA::argB, (riboB2), } \\
\text { veAl }\end{array}$ & $\begin{array}{l}\text { létrehozott deléciós törzs, } \\
\text { növekedési tesztek (nem } \\
\text { bemutatott eredmények) }\end{array}$ & $\begin{array}{l}\text { jelen munka (TN02 } \\
\text { A21 trf/2) }\end{array}$ \\
\hline HZS.290 & $\begin{array}{l}\text { hxnNA::riboB }{ }^{+}, \text {pyroA4, } \\
\text { nkuAA::argB } B^{+},(\text {riboB2 }), \\
\text { veA1 }\end{array}$ & $\begin{array}{l}\text { létrehozott deléciós törzs } \\
\text { növekedési tesztek (nem } \\
\text { bemutatott eredmények) }\end{array}$ & $\begin{array}{l}\text { jelen munka (TN02 } \\
\text { A21 trf/5) }\end{array}$ \\
\hline
\end{tabular}




\begin{tabular}{|c|c|c|c|}
\hline HZS.291 & $\begin{array}{l}\text { hxnMA::riboB }{ }^{+}, \text {biAl, } \\
\text { pabaA1, (riboB2), veA1 }\end{array}$ & $\begin{array}{l}\text { létrehozott deléciós törzs } \\
\text { növekedési tesztek (nem } \\
\text { bemutatott eredmények) }\end{array}$ & $\begin{array}{l}\text { jelen munka } \\
\text { (HZS.251 trf/2) }\end{array}$ \\
\hline HZS.292 & $\begin{array}{l}\text { hxnMA::riboB } B^{+}, \text {biAl, } \\
\text { pabaAl, (riboB2), veAl }\end{array}$ & $\begin{array}{l}\text { létrehozott deléciós törzs } \\
\text { növekedési tesztek (nem } \\
\text { bemutatott eredmények) }\end{array}$ & $\begin{array}{l}\text { jelen munka } \\
(\mathrm{HZS} .251 \mathrm{trf} / 5)\end{array}$ \\
\hline HZS.293 & $\begin{array}{l}\text { hxnMA::riboB }{ }^{+}, \\
\text {pantoB100, (riboB2), } \\
\text { veAl }\end{array}$ & növekedési tesztek & $\begin{array}{l}\text { jelen munka } \\
\text { (HZS.267 trf/3) }\end{array}$ \\
\hline HZS.294 & $\begin{array}{l}\text { hxnVA::ribo } B^{+}, \text {pyroA4, } \\
\text { nkuAA::argB } B^{+},(\text {riboB2 }), \\
\text { veAl }\end{array}$ & növekedési tesztek & $\begin{array}{l}\text { jelen munka (TN02 } \\
\text { A21 trf/1) }\end{array}$ \\
\hline HZS.295 & $\begin{array}{l}\text { hxnVA::riboB }{ }^{+}, \text {pyroA4, } \\
\text { nkuAA::argB } B^{+},(\text {riboB2 }), \\
\text { veAl }\end{array}$ & $\begin{array}{l}\text { létrehozott deléciós törzs } \\
\text { növekedési tesztek (nem } \\
\text { bemutatott eredmények) }\end{array}$ & $\begin{array}{l}\text { jelen munka (TN02 } \\
\text { A21 trf/2) }\end{array}$ \\
\hline HZS.296 & $\begin{array}{l}\text { hxnX } X:: \text { ribo } B^{+}, \text {biAl, } \\
\text { pabaAl, (riboB2), veA1 }\end{array}$ & növekedési tesztek & $\begin{array}{l}\text { jelen munka } \\
(\mathrm{HZS} .251 \mathrm{trf} / 4)\end{array}$ \\
\hline HZS.297 & $\begin{array}{l}\text { hxnXA::riboB } B^{+}, \text {biAl, } \\
\text { pabaAl, (riboB2), veAl }\end{array}$ & $\begin{array}{l}\text { létrehozott deléciós törzs } \\
\text { növekedési tesztek (nem } \\
\text { bemutatott eredmények) }\end{array}$ & $\begin{array}{l}\text { jelen munka } \\
\text { (HZS.251 trf/7) }\end{array}$ \\
\hline HZS.304 & $\begin{array}{l}\text { hxnVA::riboB }{ }^{+}, \\
\text {pantoB100, pyroA4, } \\
\text { nkuAA::arg } B^{+},(\text {riboB2), } \\
\text { veAl }\end{array}$ & $\begin{array}{l}\text { szülöi törzs } h x n V-g f p \\
\text { transzformáláshoz }\end{array}$ & $\begin{array}{l}\text { jelen munka (utód a } \\
\text { HZS.294×HZS.227 } \\
\text { keresztezésből) }\end{array}$ \\
\hline HZS.306 & $\begin{array}{l}\text { hxnNA::riboB } B^{+}, \text {pyroA4, } \\
\text { hxnR }{ }^{c} 7, \text { nkuAA::argB } B^{+} \\
(\text {riboB2), veA1 }\end{array}$ & $\begin{array}{l}\text { konstitutív mutáns } \\
\text { növekedési teszthez és } \\
\text { GC-MS/HPLC-MS } \\
\text { analízishez }\end{array}$ & $\begin{array}{l}\text { jelen munka (utód a } \\
\text { HZS.288×HZS.219 } \\
\text { keresztezésből) }\end{array}$ \\
\hline HZS.307 & $\begin{array}{l}\text { hxnR }{ }^{c} 7, \text { pantoB100, biAl, } \\
\text { veAl }\end{array}$ & $\begin{array}{l}\text { konstitutív mutáns } \\
\text { keresztezéshez }\end{array}$ & $\begin{array}{l}\text { jelen munka (utód a } \\
\text { HZS.293×HZS.219 } \\
\text { keresztezésböl) }\end{array}$ \\
\hline HZS.308 & $\begin{array}{l}\text { hxnMA::riboB } \\
\text { pantoB100, hxnR } \\
(\text { riboB2), veAl }\end{array}$ & $\begin{array}{l}\text { konstitutív mutáns } \\
\text { növekedési teszthez és } \\
\text { GC-MS/HPLC-MS } \\
\text { analízishez }\end{array}$ & $\begin{array}{l}\text { jelen munka (utód a } \\
\text { HZS.293×HZS.219 } \\
\text { keresztezésből) }\end{array}$ \\
\hline HZS.309 & $\begin{array}{l}\text { hxnVA::riboB } B^{+}, \text {pyroA4, } \\
\text { hxnR } 7 \text {, nkuAA::argB }{ }^{+} \\
(\text {riboB2), veAl }\end{array}$ & $\begin{array}{l}\text { konstitutív mutáns } \\
\text { növekedési teszthez és } \\
\text { GC-MS/HPLC-MS } \\
\text { analízishez }\end{array}$ & $\begin{array}{l}\text { jelen munka (utód a } \\
\text { HZS.294×HZS.219 } \\
\text { keresztezésből) }\end{array}$ \\
\hline HZS.310 & $\begin{array}{l}\text { hxnXA::riboB } B^{+}, h \times n R^{c} 7 \\
\text { (riboB2), veA1 }\end{array}$ & $\begin{array}{l}\text { konstitutív mutáns } \\
\text { növekedési teszthez és } \\
\text { GC-MS/HPLC-MS } \\
\text { analízishez }\end{array}$ & $\begin{array}{l}\text { jelen munka (utód a } \\
\text { HZS.296×HZS.316 } \\
\text { keresztezésből) }\end{array}$ \\
\hline HZS.316 & $\begin{array}{l}\text { hxnR } R^{c} 7, \text { pyroA4, } \\
n k u A \Delta:: \arg B^{+}, v e A 1\end{array}$ & $\begin{array}{l}\text { konstitutív mutáns } \\
\text { keresztezéshez }\end{array}$ & $\begin{array}{l}\text { jelen munka (utód a } \\
\text { HZS.288×HZS.219 } \\
\text { keresztezésből) }\end{array}$ \\
\hline HZS.393 & $\begin{array}{l}\text { hxnWA::ribo } B^{+},(\text {riboB2 }), \\
\text { pantoB100, veAl }\end{array}$ & növekedési tesztek & $\begin{array}{l}\text { jelen munka } \\
\text { (HZS.267 trf/12) }\end{array}$ \\
\hline HZS.394 & $\begin{array}{l}\text { hxnWA::ribo } B^{+},(\text {riboB2 }), \\
\text { pantoB100, veAl }\end{array}$ & $\begin{array}{l}\text { létrehozott deléciós törzs } \\
\text { növekedési tesztek (nem } \\
\text { bemutatott eredmények) }\end{array}$ & $\begin{array}{l}\text { jelen munka } \\
\text { (HZS.267 trf/15) }\end{array}$ \\
\hline
\end{tabular}




\begin{tabular}{|c|c|c|c|}
\hline HZS.404 & $\begin{array}{l}\text { riboB2, pantoB100, } \\
\text { hxnR } 7 \text {, veA1 }\end{array}$ & $\begin{array}{l}\text { transzformációs recipiens } \\
\text { törzs deléciós törzsek } \\
\text { létrehozásához }\end{array}$ & $\begin{array}{l}\text { jelen munka (utód a } \\
\text { HZS.307×HZS.123 } \\
\text { keresztezésböl) }\end{array}$ \\
\hline HZS.427 & $\begin{array}{l}\text { hxnTA::pabaA }{ }^{+}, \\
(\text {pabaA1), riboB2, anAl, } \\
\text { hxnR } R^{c} \text {, veAl }\end{array}$ & $\begin{array}{l}\text { GC-MS/HPLC-MS } \\
\text { analízis }\end{array}$ & (Ámon, 2018) \\
\hline HZS.429 & $\begin{array}{l}\text { hxnY } \triangle: \because r i b o B^{+},(\text {riboB2 }), \\
\text { pabaA1, biAl, hxnR } 7, \\
\text { veA1 }\end{array}$ & $\begin{array}{l}\text { GC-MS/HPLC-MS } \\
\text { analízis }\end{array}$ & (Ámon, 2018) \\
\hline HZS.517 & $\begin{array}{l}\text { hxnWA::ribo } B^{+},(\text {riboB } 2), \\
\text { pantoB100, hxnR } 7, \text { veAl }\end{array}$ & $\begin{array}{l}\text { konstitutív mutáns } \\
\text { növekedési teszthez és } \\
\text { GC-MS/HPLC-MS } \\
\text { analízishez }\end{array}$ & $\begin{array}{l}\text { jelen munka (utód a } \\
\text { HZS.394×307 } \\
\text { keresztezésből) }\end{array}$ \\
\hline HZS.534 & $\begin{array}{l}\text { hxnXA::riboB }{ }^{+},(\text {riboB } 2), \\
1 \text { db ektopikus pDsRed- } \\
\text { SKL-argB plazmid, } \\
\text { pantoB100, biA1, pabaA1, } \\
\text { veA1 }\end{array}$ & fluoreszcens mikroszkópia & $\begin{array}{l}\text { jelen munka (utód a } \\
\text { HZS.305×NA1322 } \\
\text { keresztezésböl) }\end{array}$ \\
\hline HZS.548 & $\begin{array}{l}\text { hxnSA::pabaA } A^{+}, \text {pabaAl, } \\
\text { anAl, riboB2, veAl }\end{array}$ & $\begin{array}{l}\text { növekedési tesztek, } \\
\text { többszörösen deléciós } \\
\text { mutánsok létrehozása }\end{array}$ & $\begin{array}{l}\text { jelen munka (HZS. } \\
123 \text { trf/9) }\end{array}$ \\
\hline HZS.549 & $\begin{array}{l}\text { hxnSA::pabaA } A^{+}, \text {pabaAl, } \\
\text { anA1, riboB2, veAl }\end{array}$ & $\begin{array}{l}\text { létrehozott deléciós törzs } \\
\text { növekedési tesztek (nem } \\
\text { bemutatott eredmények) }\end{array}$ & $\begin{array}{l}\text { jelen munka (HZS. } \\
123 \text { trf/18) }\end{array}$ \\
\hline HZS.555 & 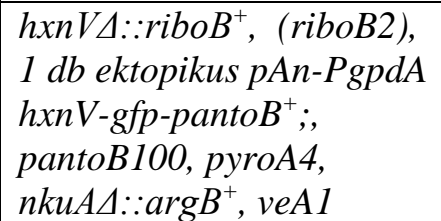 & mikroszkópos vizsgálatok & $\begin{array}{l}\text { jelen munka } \\
\text { (HZS.304 trf/25) }\end{array}$ \\
\hline HZS.558 & 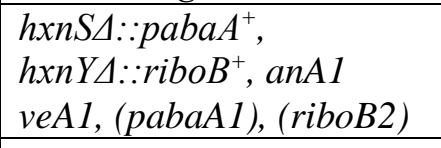 & növekedési tesztek & $\begin{array}{l}\text { jelen munka (utód a } \\
\text { HZS.223×HZS.548 } \\
\text { keresztezésböl) }\end{array}$ \\
\hline HZS.564 & $\begin{array}{l}n k u A \Delta:: \arg B^{+}, \text {pabaAl, } \\
\text { riboB2, pyroA4, veA1 }\end{array}$ & $\begin{array}{l}\text { transzformációs recipiens } \\
\text { törzs deléciós törzsek } \\
\text { létrehozásához }\end{array}$ & $\begin{array}{l}\text { jelen munka (utód a } \\
\text { TN02 } \\
\text { A21×HZS.544 } \\
\text { keresztezésböl) }\end{array}$ \\
\hline HZS.568 & $\begin{array}{l}\text { hxnShxnTA::pabaA }{ }^{+}, \\
\text {pabaAl, pyroA4, riboB2, } \\
\text { nkuAA::argB }{ }^{+} \text {, veAl }\end{array}$ & $\begin{array}{l}\text { növekedési tesztek, } \\
\text { többszörösen deléciós } \\
\text { mutánsok létrehozása }\end{array}$ & $\begin{array}{l}\text { jelen munka } \\
(\mathrm{HZS} .564 \mathrm{trf} / 10)\end{array}$ \\
\hline HZS.569 & 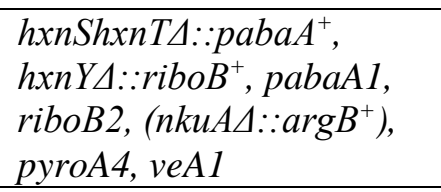 & növekedési tesztek & $\begin{array}{l}\text { jelen munka (utód a } \\
\text { HZS.223×HZS.568 } \\
\text { keresztezésböl) }\end{array}$ \\
\hline HZS.579 & $\begin{array}{l}\text { hxnX } \triangle \text { ::riboB }{ }^{+},(\text {riboB2), } \\
1 \text { db ektopikus pDsRed- } \\
\text { SKL-argB plazmid, } 7 \text { db } \\
\text { ektopikus pAn-PgpdA- } \\
\text { hxnX-gfp-pantoB }{ }^{+} \\
\text {plazmid, pantoB100, biAl, } \\
\text { pabaA1, veAl }\end{array}$ & mikroszkópos vizsgálatok & $\begin{array}{l}\text { jelen munka (HZS. } \\
534 \operatorname{trf} / 27)\end{array}$ \\
\hline
\end{tabular}




\begin{tabular}{|c|c|c|c|}
\hline HZS.582 & $\begin{array}{l}\Delta h x n M:: r i b o B^{+}, \\
\triangle h x n X:: r i b o B^{+},(\text {riboB2 }), \\
\text { pantoB100, veAl }\end{array}$ & $\begin{array}{l}\text { mutáns törzs GC- } \\
\text { MS/HPLC-MS analízishez }\end{array}$ & $\begin{array}{l}\text { jelen munka (utód a } \\
\text { HZS.293×HZS.297 } \\
\text { keresztezésböl) }\end{array}$ \\
\hline HZS.584 & $\begin{array}{l}\Delta h x n M:: \text { ribo }^{+}, \\
\triangle h x n V:: \text { riboB } \\
\text { pabaAl, biAl, veAl }\end{array}$ & $\begin{array}{l}\text { mutáns törzs GC- } \\
\text { MS/HPLC-MS analízishez }\end{array}$ & $\begin{array}{l}\text { jelen munka (utód a } \\
\text { HZS.294×HZS.292 } \\
\text { keresztezésböl) }\end{array}$ \\
\hline HZS.588 & $\begin{array}{l}\Delta h \times n M:: \text { ribo } B^{+}, \\
\triangle h \times n W:: \text { ribo } B^{+},(\text {riboB } 2), \\
\text { pabaAl, pantoB100, veAl }\end{array}$ & $\begin{array}{l}\text { mutáns törzs GC- } \\
\text { MS/HPLC-MS analízishez }\end{array}$ & $\begin{array}{l}\text { jelen munka (utód a } \\
\text { HZS.393×HZS.292 } \\
\text { keresztezésből) }\end{array}$ \\
\hline HZS.599 & $\begin{array}{l}\text { hxnSA::pabaA }{ }^{+}, \\
(\text {pabaAl), riboB2, veAl }\end{array}$ & $\begin{array}{l}\text { növekedési tesztek, } \\
\text { többszörösen deléciós } \\
\text { mutánsok létrehozása }\end{array}$ & $\begin{array}{l}\text { jelen munka } \\
\text { (HZS.120 trf/2) }\end{array}$ \\
\hline HZS.747 & 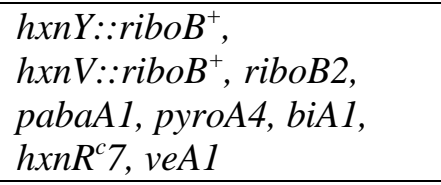 & $\begin{array}{l}\text { pigmentképződés } \\
\text { vizsgálata }\end{array}$ & $\begin{array}{l}\text { jelen munka (utód a } \\
\text { HZS.429×HZS.309 } \\
\text { keresztezésböl) }\end{array}$ \\
\hline HZS.748 & 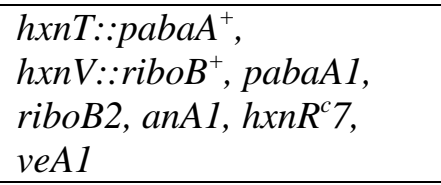 & $\begin{array}{l}\text { pigmentképződés } \\
\text { vizsgálata }\end{array}$ & $\begin{array}{l}\text { jelen munka (utód a } \\
\text { HZS.427×HZS.537 } \\
\text { keresztezésből) }\end{array}$ \\
\hline HZS.749 & $\begin{array}{l}\text { hxnWhxnVA::riboB }{ }^{+}, \\
\text {riboB2, pantoB100, } \\
\text { hxnR }{ }^{c} \text {, veAl }\end{array}$ & $\begin{array}{l}\text { pigmentképződés } \\
\text { vizsgálata }\end{array}$ & $\begin{array}{l}\text { jelen munka } \\
(\mathrm{HZS} .404 \mathrm{trf} / 1)\end{array}$ \\
\hline HZS.750 & $\begin{array}{l}\text { hxnXhxnWhxnVA::ribo } B^{+}, \\
\text {riboB2, pantoB100, } \\
\text { hxnR }^{c} 7, \text { veA1 }\end{array}$ & $\begin{array}{l}\text { pigmentképződés } \\
\text { vizsgálata }\end{array}$ & $\begin{array}{l}\text { jelen munka } \\
\text { (HZS.404 trf/5) }\end{array}$ \\
\hline TNO2 A21 & $\begin{array}{l}\text { riboB2, pyroA4, } \\
\text { nkuAA::argB }{ }^{+}, \text {veAl }\end{array}$ & növekedési tesztek & $\begin{array}{l}\text { (Nayak és mtsai., } \\
\text { 2006) }\end{array}$ \\
\hline FGSC A872 & $h x n R^{c} 7, b i A 1, v e A l$ & $\begin{array}{l}\text { hxnR } R^{c} 7 \text { dupla deléciós } \\
\text { mutánsok létrehozása }\end{array}$ & $\begin{array}{l}\text { (Scazzocchio és } \\
\text { mtsai., 1973) }\end{array}$ \\
\hline CS308 & pyroA4, hxn6, veAl & szülői törzs keresztezéshez & $\begin{array}{l}\text { Scazzocchio } \\
\text { törzsgyüjtemény }\end{array}$ \\
\hline
\end{tabular}

A táblázatban feltüntetett Aspergillus nidulans törzsek genotípusának leírása során használt, a kísérleteink szempontjából fontosabb jelölések magyarazata:

- anAl: tiamin auxotrófia

- $\operatorname{argB2:}$ arginin auxotrófia

- biAl: biotin auxotrófia

- pabaA1: para-amino-benzoesav auxotrófia

- pantoB100: pantoténsav auxotrófia

- pyroA4: piridoxin auxotrófia

- riboB2: riboflavin auxotrófia

- pyrG89: a pyrG gén mutációja, mely hatása a növekedési képtelenség uracil és uridin hiányában

- veAl: ivartalan spóraképzés fény hiányában is 
- yA2: yelA-ban (para-difenol oxidáz) történt mutáció, melynek következtében a pigmentszintézis sérül, ami sárga konídiumokat eredményez (Clutterbuck, 1972)

- $\quad n k u A$ : a kettős szálú DNS törések esetén a nem-homológ végek összekapcsolását végző javító mechanizmusokhoz szükséges (Nayak és mtsai, 2006); mutációja transzformálás során csökkenti az ektopikus integrációk lehetőségét

- $\quad p D s R e d-S K L-\operatorname{argB}$ : peroxiszómával fúzionált vörös fluoreszcens protein

- hxnR 7: hxnR gént konstitutívan, indukció hiányában is kifejező mutáció

Ámon J, Fernandez-Martin R, Bokor E, Cultrone A, Kelly JM, Flipphi M, Scazzocchio C, Hamari Z (2017) A eukaryotic nicotinate-inducible gene cluster: convergent evolution in fungi and bacteria. Open Biol 7.

Ámon J (2018) Az első eukarióta nikotinsav hasznosítási útvonal felderítése, szabályozása és az útvonal enzimeinek vizsgálata Aspergillus nidulans modellszervezetben $\mathrm{PhD}$ értekezés Thesis, University of Szeged, Szeged.

Clutterbuck AJ (1972) Absence of laccase from yellow-spored mutants of Aspergillus nidulans. J Gen Microbiol 70: 423-435.

Hamari Z, Amillis S, Drevet C, Apostolaki A, Vagvolgyi C, Diallinas G \& Scazzocchio C (2009) Convergent evolution and orphan genes in the Fur4p-like family and characterization of a general nucleoside transporter in Aspergillus nidulans. Mol Microbiol 73: 43-57.

Nayak T, Szewczyk E, Oakley CE, Osmani A, Ukil L, Murray SL, Hynes MJ, Osmani SA, Oakley BR (2006) A versatile and efficient gene-targeting system for Aspergillus nidulans. Genetics 172: 1557-1566.

Scazzocchio C, Holl FB \& Foguelman AI (1973) The genetic control of molybdoflavoproteins in Aspergillus nidulans. Allopurinol-resistant mutants constitutive for xanthinedehydrogenase. Eur J Biochem 36: 428-445.

\section{2. melléklet}

\section{Alkalmazott Escherichia coli törzs}

\begin{tabular}{|c|c|c|c|}
\hline Törzs & Genotípus & Felhasználás & Hivatkozás \\
\hline JM109 & $\begin{array}{l}\text { endA1 glnV44 thi-1 relA1 } \\
\text { gyrA96 recAl mcrB }{ }^{+} \Delta\left(\text { lac- }^{-}\right. \\
\text {proAB) el4- }\left[F^{\prime} \text { traD36 }\right. \\
\text { proAB }{ }^{+} \text {lacl }^{q} \text { lacZAM15] } \\
\text { hsdR17( }\left(r_{K}^{-} m_{K}^{+}\right)\end{array}$ & $\begin{array}{l}\text { vektorkonstrukciók } \\
\text { felszaporítása }\end{array}$ & $\begin{array}{l}\text { http://openwetware.org/wi } \\
\text { ki/E._coli_genotypes\#JM1 } \\
09\end{array}$ \\
\hline
\end{tabular}




\section{3. melléklet}

\section{Felhasznált vektorok}

A: GFP-fúziós konstrukciókhoz felhasznált vektorok

\begin{tabular}{|l|l|l|}
\hline \multicolumn{1}{|c|}{ Név } & \multicolumn{1}{|c|}{ Felhasználás } & \multicolumn{1}{c|}{ Hivatkozás } \\
\hline pAN-HZS-1 & $\begin{array}{l}\text { pAN-HZS-12 és pAN-HZS- } \\
13 \text { vektorok létrehozása }\end{array}$ & (Karácsony és mtsai., 2015) \\
\hline pAN-HZS-12 & $\begin{array}{l}h x n V \text {-gfp fúziós konstrukció } \\
\text { létrehozása }\end{array}$ & $\begin{array}{l}\text { jelen munka, 5.11.1. } \\
\text { alfejezet }\end{array}$ \\
\hline pAN-HZS-13 & $\begin{array}{l}g f p \text { - } h x n X \text { fúziós konstrukció } \\
\text { létrehozása }\end{array}$ & $\begin{array}{l}\text { jelen munka, 5.11.2. } \\
\text { alfejezet }\end{array}$ \\
\hline
\end{tabular}

Karácsony Z, Gácser A, Vágvölgyi C \& Hamari Z (2015) Further characterization of the role of the mitochondrial high-mobility group box protein in the intracellular redox environment of Aspergillus nidulans. Microbiology 161: 1897-1908.

\section{B: A. nidulans génbank transzformálás során alkalmazott vektor}

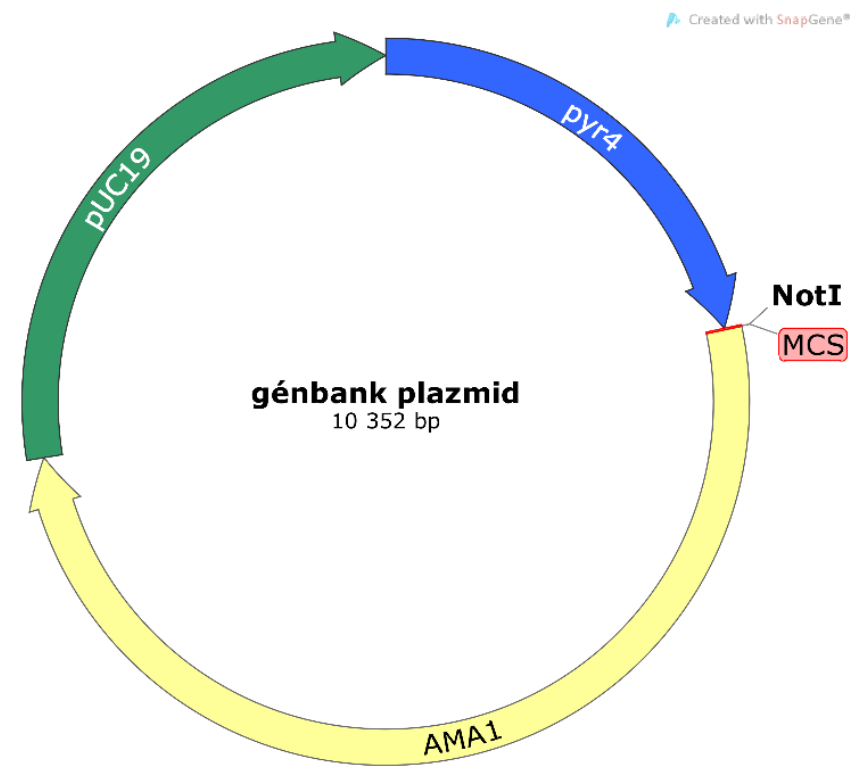

- pyr4: Neurospora crassa vad típusú allélje, mely komplementálja az A. nidulans pyrG89 auxotrófiáját

- pUC19: E. coli replikációs origó

- AMA1: autonóm replikációt és hatékonyabb transzformációt biztosító A. nidulans szekvencia

- MCS: Multi Cloning Site, az A. nidulans genomszakaszok NotI hasítóhelyre történő beklónozásának pozíciója 


\section{4. melléklet}

\section{Alkalmazott indítószekvenciák}

\begin{tabular}{|c|c|}
\hline \multicolumn{2}{|c|}{ Génbankkal transzformált hxn6 törzs szekvenálásához használt indítószekvenciák } \\
\hline T3 & 5' - aattaaccctcactaaaggg - 3' \\
\hline T7 & 5' - cattatgctgagtgatatcccg - 3' \\
\hline walk AN9162down frw1 & 5' - tagattggtttaagcgagcg - 3' \\
\hline walk AN9162 down frw2 & 5' - ccaaacgcaggacgaatatacac - 3' \\
\hline walk AN9162 down frw3 & $5^{\prime}-$ ccetgctcacaaactatcct $-3^{\prime}$ \\
\hline walk AN9162 frw4 & 5' - atgcgtcaatcttcgaggag - 3' \\
\hline hxnV down frw & 5' - gtttgcgaagccttggtcgtg - 3' \\
\hline hxnW upst rev & $5^{\prime}-$ gtgttcttggcgagcgatgcc - 3' \\
\hline hxnW AS frw & $5^{\prime}$ - gcagatcgtggtgttcttcgtag $-3^{\prime}$ \\
\hline hxnV upst nest frw & 5' - caagggtgaactgcttcgctagg-3' \\
\hline hxnV upst rev & $5^{\prime}$ - caagacggtgggtggaggagt - 3' \\
\hline hxnV upst seq & $5^{\prime}-$ atccgcgtcaatatcattgtc - 3' \\
\hline hxnW down frw & $5^{\prime}$ - cagcactgtaccactgcgag - 3' \\
\hline hxnV down rev & 5' - gatcagactagtgctagtggttactaac - 3' \\
\hline hxnX F366 & $5^{\prime}$ - gtctgaggcgcagtatccag - 3' \\
\hline hxnX F716 & 5' - cacaggtcaactactggcttgg - 3' \\
\hline hxnX F1066 & $5^{\prime}-$ gctgccatacttagcatctg - 3' \\
\hline hxnV F513 & $5^{\prime}-$ tcggacccgtatattctcct $-3^{\prime}$ \\
\hline hxnV F 740 & $5^{\prime}$ - ggagttcatccetgatgcgc - 3' \\
\hline hxnV F1016 & $5^{\prime}$ - ctaaggcaacaccgcaatatgtc - 3' \\
\hline hxnV F1449 & $5^{\prime}-$ gatcgcaaacgacctcattgc $-3^{\prime}$ \\
\hline hxnV F1811 & 5' - cgacgtccattctagcaatttctg - 3' \\
\hline hxnV F2016 & $5^{\prime}$ - gactgtgtatctggatgatgtg - 3' \\
\hline hxnV ReTi rev & 5' - gaaatgaactattccgcgtaacag - 3' \\
\hline hxnV stop 307 frw & 5' - gatgatcaatgcatacagcactaccac - 3' \\
\hline \multicolumn{2}{|c|}{ A hxnV gén cDNS régiójának felsokszorozására használt indítószekvenciák } \\
\hline hxnV cDNA UJ EcoRI frw & 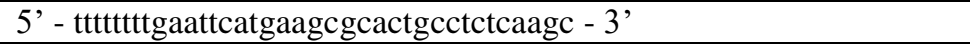 \\
\hline hxnV cDNA PstI rev & 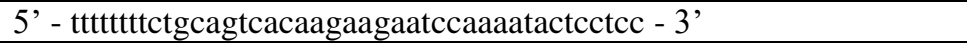 \\
\hline \multicolumn{2}{|c|}{ A hxnV cDNS régiójának szekvenálásához használt indítószekvenciák } \\
\hline hxnV seq 13F & $5^{\prime}$ - cagatcacgaccaaggcttc - 3' \\
\hline hxnV seq 492F & $5^{\prime}$ - gtaatgagtctggcgacccttc $-3^{\prime}$ \\
\hline hxnV F513 & $5^{\prime}-$ tcggacccgtatattctcct - 3' \\
\hline hxnV F1016 & $5^{\prime}$ - ctaaggcaacaccgcaatatgtc - 3' \\
\hline hxnV F1811 & $5^{\prime}$ - cgacgtccattctagcaatttctg - 3' \\
\hline \multicolumn{2}{|c|}{ Géndeléciókhoz alkalmazott indítószekvenciák } \\
\hline hxnS rup frw & 5' - gtgtactcgttcatcacgccaaag - 3' \\
\hline hxnS rup rev & $5^{\prime}-$ cttgctgttggagacgacttgg - 3' \\
\hline hxnS rpaba kim frw & $5^{\prime}$ - ccaagtcgtctccaacagcaaggcacatagctattacacgtatgtttgagac - $3^{\prime}$ \\
\hline hxnS rpaba kim rev & 5' - catcgccacagctcaagttctgtagtttgcttgaatggctaacgaggcattg - 3' \\
\hline hxnT paba kim rev & 5' - ctatctgtattctgtgtcgtagtattcatggtagtttgcttgaatggctaacgaggcattg - 3' \\
\hline hxnS rdown frw & 5' - agaacttgagctgtggcgatg - 3' \\
\hline hxnS rdown rev & 5' - agagatacagaacatgcatttcttccc - 3' \\
\hline hxnT down frw & $5^{\prime}$ - gaatactacgacacagaatacagatagac - $3^{\prime}$ \\
\hline hxnT down rev & 5' - catagtcttaaccacgagacgatcagtaac - 3' \\
\hline hxnS rup nest frw & 5' - cagttgaggcatcttgatgtgag - 3' \\
\hline hxnT rev & $5^{\prime}$ - ctattgagcgaaagggtagtccgtatag - 3' \\
\hline hxnT down nest rev & $5^{\prime}-$ tctgttctactacaggcagcgagttttgtc - 3' \\
\hline hxnV upst frw & $5^{\prime}-$ acttctcaaactgctcgcgtcc $-3^{\prime}$ \\
\hline hxnV upst rev & 5' - caagacggtgggtggaggagt - 3' \\
\hline hxnV upst nest frw & 5' - caagggtgaactgcttcgctagg - 3' \\
\hline hxnV down nest rev & 5' - cgaaattgtttctctgcaactggg - 3' \\
\hline hxnV ribokim frw & $5^{\prime}$ - actcctccacccaccgtcttgcgtacgtagtgtagattcaggcacattgaagcg - 3' \\
\hline hxnV ribokim rev & 5' - cacgaccaaggcttcgcaaacggaaaactgccatgactactaggtggtgctatc - 3' \\
\hline
\end{tabular}




\begin{tabular}{|c|c|}
\hline hxnV down frw & $5^{\prime}-$ gtttgcgaagccttggtcgtg - 3' \\
\hline hxnV down rev & 5 - ctgagacgtcagtgaggacat - 3 \\
\hline hxnV AS frw & $5^{\prime}$ - cagcgtcaagtctcatatctatactg - $3^{\prime}$ \\
\hline hxnV AS rev & 5 ' - cagagcacgggtacaaagaaggtg - 3' \\
\hline hxnW upst frw & $5^{\prime}-$ actcctccacccaccgtcttg - $3^{\prime}$ \\
\hline hxnW upst rev & $5^{\prime}-$ gtgttcttggcgagcgatgcc $-3^{\prime}$ \\
\hline hxnW ribokim frw & $5^{\prime}$ - ggcatcgctcgccaagaacaccgtacgtagtgtagattcaggcacattgaagcg - $3^{\prime}$ \\
\hline hxnW ribokim rev & 5 - ctcgcagtggtacagtgctgggaaactgccatgactactaggtggtgctatc - 3 \\
\hline hxnW down frw & 5 ' - cagcactgtaccactgcgag - 3' \\
\hline hxnW down rev & 5 - gatcagactagtgctagtggttactaac -3 \\
\hline hxnW down nest rev & 5 - ccatgaaatggattgtaaacctcaag - 3 \\
\hline hxnW AS frw & $5^{\prime}$ - gcagatcgtggtgttcttcgtag - $3^{\prime}$ \\
\hline hxnW AS rev & 5 ' - ctcgcagtggtacagtgctg - 3 \\
\hline hxnX upst nest frw & $5^{\prime}-$ caccttctttgtacccgtgctctg $-3^{\prime}$ \\
\hline hxnX ribokim frw & $5^{\prime}$ - cccagttgcagagaaacaatttcgcgtacgtagtgtagattcaggcacattgaagcg - 3 \\
\hline hxnX ribokim rev & $5^{\prime}$ - gatgctacctgttcctctgattcaacggaaaactgccatgactactaggtggtgctatc $-3^{\prime}$ \\
\hline hxnX down frw & 5 - gttgaatcagaggaacaggtagcatc -3 \\
\hline hxnX down rev & 5 ' - gagacttgtactcttatcgttcgc - 3' \\
\hline hxnX frw & $5^{\prime}-$ cgacagctattgctgcggac $-3^{\prime}$ \\
\hline hxnN upst frw & 5 - cgtagaggctgttttcatgtcctg - 3 \\
\hline hxnN upst rev & $5^{\prime}-$ cgtttctttgcgactgtctgctc $-3^{\prime}$ \\
\hline hxnN ribokim frw & $5^{\prime}$ - gagcagacagtcgcaaagaaacgcgtacgtagtgtagattcaggcacattgaagcg - 3' \\
\hline hxnN ribokim rev & 5 ' - ctagccgtttcccaattacctgcggaaaactgccatgactactaggtggtgctatc - 3 \\
\hline hxnN down frw & $5^{\prime}$ - gcaggtaattgggaaacggctag - $3^{\prime}$ \\
\hline hxnN down rev & $5^{\prime}$ - gatgcacagattgtgaaacgattg - $3^{\prime}$ \\
\hline hxnN down nest rev & $5^{\prime}$ - gctcttaaactcatcgcacatctg - $3^{\prime}$ \\
\hline hxnN upst nest frw & $5^{\prime}$ - cggagaatatgtggttcgagc $-3^{\prime}$ \\
\hline hxnM upst frw & $5^{\prime}$ - ctcattgtagtagcattcattgtcgc $-3^{\prime}$ \\
\hline hxnM upst rev & 5 ' - cgacaccgtaggatacgagaac - $3^{\prime}$ \\
\hline hxnM ribokim frw & $5^{\prime}$ - gttctcgtatcctacggtgtcgcgtacgtagtgtagattcaggcacattgaagcg $-3^{\prime}$ \\
\hline hxnM ribokim rev & $5^{\prime}-$ gctcttaaactcatcgcacatctgggaaaactgccatgactactaggtggtgctatc $-3^{\prime}$ \\
\hline hxnM down frw & $5^{\prime}$ - cagatgtgcgatgagtttaagagc $-3^{\prime}$ \\
\hline hxnM down rev & 5 - ggcgaaacttgagtacgagtg - $3^{\prime}$ \\
\hline hxnM upst nest frw & 5 - cgaatcccgcaaagcattctg - 3' \\
\hline hxnM down nest rev & 5' - gatgtccgggtattcggtgcag - 3' \\
\hline \multicolumn{2}{|c|}{ PCR előszelekciókhoz alkalmazott indítószekvenciák } \\
\hline hxnT prom frw2 & 5 ' - gattctcggtcatgtagagcagg - $3^{\prime}$ \\
\hline hxnT prom rev2 & 5 ' - gcctgcatggacaagctatttag - 3' \\
\hline hxnS ReTi frw & $5^{\prime}-$ gagcatttctatcttgagacga $-3^{\prime}$ \\
\hline hxnS ReTi rev & 5 ' - ccattgtgttctgggtactg - 3' \\
\hline hxnT frw & 5 ' - ctttgcgctgcagcaccgtgttgtccaag - $3^{\prime}$ \\
\hline hxnT rev & $5^{\prime}$ - ctattgagcgaaagggtagtccgtatag - 3' \\
\hline hxnV AS frw & $5^{\prime}$ - cagcgtcaagtctcatatctatactg - $3^{\prime}$ \\
\hline hxnV AS rev & $5^{\prime}$ - cagagcacgggtacaaagaaggtg - $3^{\prime}$ \\
\hline hxnX frw & 5' - cgacagctattgctgcggac - 3' \\
\hline hxnX NotI rev & $5^{\prime}-\mathrm{tttttttgcggccgctcataaccgcgatgctacctgttc}-3^{\prime}$ \\
\hline hxnW AS frw & $5^{\prime}$ - gcagatcgtggtgttcttcgtag - 3' \\
\hline hxnW AS rev & $5^{\prime}$ - ctcgcagtggtacagtgctg - 3' \\
\hline hxnM ReTi frw & 5' - aagacctaccgcatgattacag - 3' \\
\hline hxnM ReTi rev & $5^{\prime}$ - cagcaattccgtcatctcct - 3' \\
\hline hxnN ReTi frw & 5' - cattgcatggttctatcttggg - 3' \\
\hline hxnN ReTi rev & $5^{\prime}$ - atccatacaatcccagaatgct - $3^{\prime}$ \\
\hline \multicolumn{2}{|c|}{ GFP fúziós törzsek készítéséhez alkalmazott indítószekvenciák } \\
\hline hxnV NcoI frw & $5^{\prime}$ - ttttttttccatggagcgcactgcctctcaag - $3^{\prime}$ \\
\hline hxnV GFP linker NcoI rev & 5 ' - tttttttccatggtatcaagatcgactgtatcaataagcaagaagaatccaaaatactcctccac - 3' \\
\hline 1pGPD int frw & 5' - cagtatattcatcttcccatccaagaac - 3' \\
\hline 10GFP linker hmgB rev & 5 ' - atcaagatcgactgtatcaataagcttgtacagctcgtccatgccgtg $-3^{\prime}$ \\
\hline linker kim hxnX frw & $5^{\prime}$ - acaag cttattgatacagtcgatcttgat atgcccatcccagttgcagagaaac $-3^{\prime}$ \\
\hline
\end{tabular}




\begin{tabular}{|c|c|}
\hline hxnW down nest rev & $5^{\prime}$ - ccatgaaatggattgtaaacctcaag - $3^{\prime}$ \\
\hline 5GFP NcoI start frw & $5^{\prime}-$ ttttttttccatggtgagcaagggegaggagc -3 \\
\hline hxnX NotI rev & 5'- tttttttgcggecgctcataaccgcgatgctacctgttc - 3' \\
\hline \multicolumn{2}{|c|}{ Southern-hibridizációnál használt jelölt próbák elkészítéséhez használt indítószekvenciák } \\
\hline hxnS rdown frw & 5' - agaacttgagctgtggcgatg - 3' \\
\hline hxnT rev & $5^{\prime}-$ ctattgagcgaaagggtagtccgtatag - $3^{\prime}$ \\
\hline hxnS rup nest frw & 5 ' - cagttgaggcatcttgatgtgag - $3^{\prime}$ \\
\hline hxnS rup rev & 5' - cttgctgttggagacgacttgg - 3' \\
\hline hxnT down frw & $5^{\prime}$ - gaatactacgacacagaatacagatagac $-3^{\prime}$ \\
\hline hxnT down rev & 5 ' - catagtcttaaccacgagacgatcagtaac $-3^{\prime}$ \\
\hline hxnV upst nest frw & 5' - caagggtgaactgcttcgctagg - 3' \\
\hline hxnV upst rev & $5^{\prime}$ - caagacggtgggtggaggagt - 3' \\
\hline hxnV AS frw & 5 ' - cagcgtcaagtctcatatctatactg - 3' \\
\hline hxnV down nest rev & $5^{\prime}-$ cgaaattgtttctctgcaactggg - 3' \\
\hline hxnW upst rev & $5^{\prime}-$ gtgttcttggcgagcgatgcc $-3^{\prime}$ \\
\hline hxnM upst nest frw & 5' - cgaatcccgcaaagcattctg - 3' \\
\hline hxnM upst rev & 5 ' - cgacaccgtaggatacgagaac -3 \\
\hline hxnN upst nest frw & 5' - cggagaatatgtggttcgagc - 3' \\
\hline hxnN upst rev & 5 ' - cgtttctttgcgactgtctgctc $-3^{\prime}$ \\
\hline
\end{tabular}

\section{5. melléklet}

A 111 g/mol (A) és a 131 g/mol (B) molekulasúlyú vegyületek MS² tömegspektruma

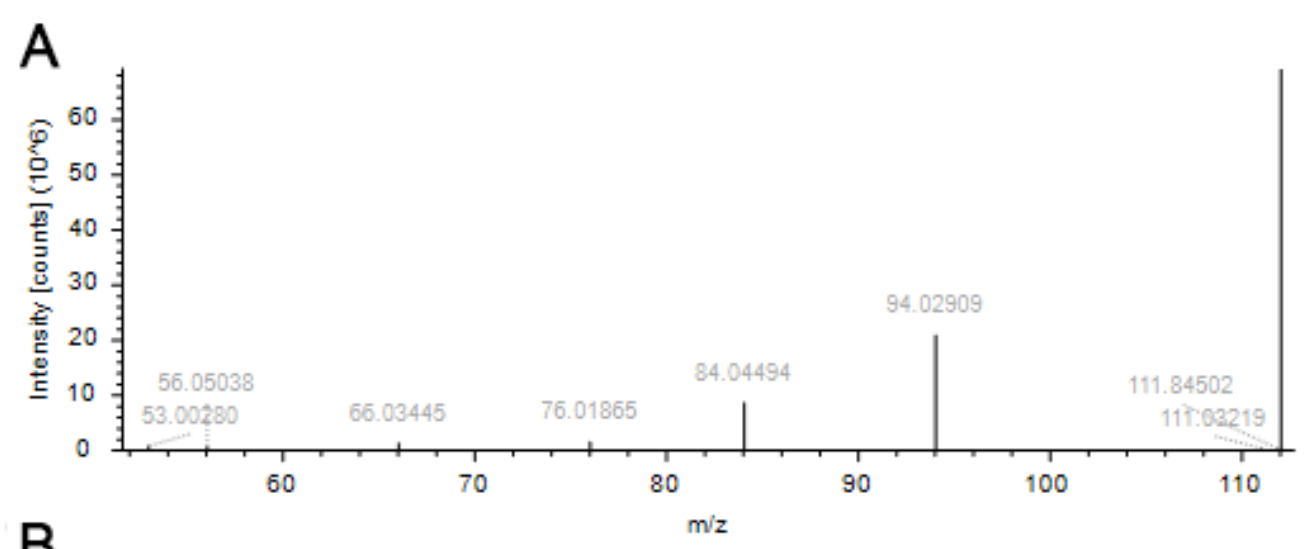

B

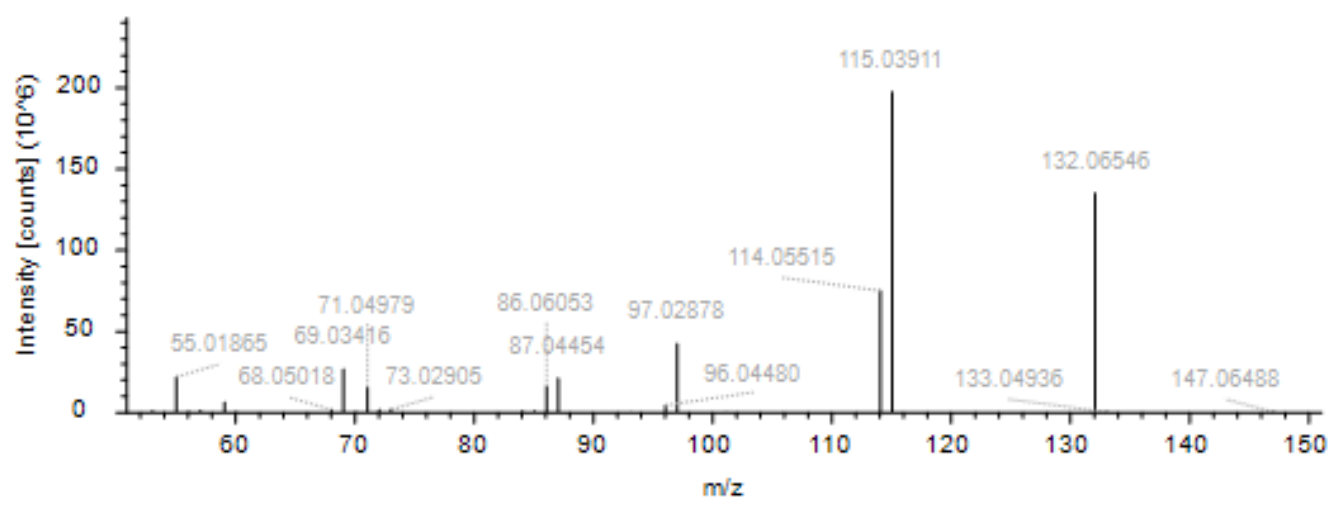




\section{6. melléklet}

\section{Gomba genomok összehasonlításához alkalmazott adatok (az adatokat Michel Flipphi}

rendezte össze)

hxn cluster Aspergillus aculeatus: size 51,822 nt

$>$ Aspergillus aculeatus < scaffold_11|1080376|1082357

$>$ A.aculeatus_hxnZ $=\underline{1,981 \mathrm{nt}}$

$<461 \mathrm{nt}<$

$>$ Aspergillus aculeatus < scaffold_11|1082818|1083972

$>$ A.aculeatus_hxnY $=\underline{1,154 \mathrm{nt}}$

$<409$ nt $>$

$>$ Aspergillus aculeatus > scaffold_11|1084381|1086181

$>$ A.aculeatus_hxnP $=\underline{1,800 \mathrm{nt}}$

$>283 \mathrm{nt}>$

>Aspergillus aculeatus > scaffold_11|1086464|1088927

$>$ A.aculeatus_hxnR $=\underline{2,463 n t}$

$>387 \mathrm{nt}>$

>Aspergillus aculeatus > scaffold_11|1089314|1093677

$>$ A.aculeatus_hxnS-PHII $=\underline{4,363 \mathrm{nt}}$

$>\underline{33,173 \mathrm{nt}}<$

$>$ Aspergillus aculeatus < scaffold_11|1126850|1128511

$>$ A.aculeatus_hxnX $=\underline{1,661 \mathrm{nt}}$

$\langle 244 \mathrm{nt}>$

$>$ Aspergillus aculeatus > scaffold_11|1128755|1129706

$>$ A.aculeatus_hxnW $=\underline{951 \mathrm{nt}}$

$>245 \mathrm{nt}>$

$>$ Aspergillus aculeatus > scaffold_11|1129951|1132198

$>$ A.aculeatus_hxnV $=\underline{2,247 \mathrm{nt}}$

\section{Unlinked:}

>Aspergillus aculeatus > scaffold_14|1009693|1011600

$>$ A.aculeatus_amidase $=\underline{1908 \mathrm{nt}}$

$>662 \mathrm{nt}>$

>Aspergillus aculeatus > scaffold_14|1012262|1013422

C-N_hydrolase

$>$ A.aculeatus_HxnM $=\underline{1161 \mathrm{nt}}$

\section{hxn cluster Aspergillus carbonarius: size 20,426 nt}

>Aspergillus carbonarius < scaffold_11|974532|976267

$>$ A.carbonarius_hxnX $=\underline{1,735 \mathrm{nt}}$

$\langle 267 \mathrm{nt}>$

$>$ Aspergillus carbonarius > scaffold_11|976534|977505

$>$ A.carbonarius_hxnW $=\underline{971 \mathrm{nt}}$

$>252 \mathrm{nt}>$

$>$ Aspergillus carbonarius > scaffold_11|977757|979958

$>$ A.carbonarius_hxnV $=\underline{2,201 \mathrm{nt}}$

\author{
$>347$ nt $<$ \\ $>$ Aspergillus carbonarius < scaffold_11|980305|984734 \\ $>$ A.carbonarius_hxnS-PHII $=\underline{4,429 \mathrm{nt}}$ \\ $<480 \mathrm{nt}>$ \\ $>$ Aspergillus carbonarius > scaffold_11|985214|986441 \\ $>$ A.carbonarius_hxnT $=\underline{1,227 \mathrm{nt}}$ \\ $>96 \mathrm{nt}<$ \\ $>$ Aspergillus carbonarius < scaffold_11|986537|989113 \\ $>$ A.carbonarius_hxnR $=\underline{2,576 \mathrm{nt}}$ \\ $<227$ nt $<$ \\ $>$ Aspergillus carbonarius < scaffold_11|989340|991124 \\ $>$ A.carbonarius_hxnP $=\underline{1,784 \mathrm{nt}}$ \\ $<398$ nt $>$ \\ > Aspergillus carbonarius > scaffold_11|991522|992664 \\ $>$ A.carbonarius_hxnY $=\underline{1,142 \mathrm{nt}}$ \\ $>385$ nt $>$ \\ > Aspergillus carbonarius > scaffold_11|993049|994958 \\ $>$ A.carbonarius_hxnZ $=\underline{1,909 \mathrm{nt}}$
}

\section{Unlinked}

>Aspergillus carbonarius < scaffold_20|95457|96608

C-N_hydrolase

$>$ A.carbonarius_HxnM $=1,152 \mathrm{nt}$

$<555$ nt $<$

$>$ Aspergillus carbonarius < scaffold_20|97163|99055

$>$ A.carbonarius_amidase $=1,893 \mathrm{nt}$

hxn cluster Aspergillus flavus (oryzae/sojae): size 19,176 nt

$>$ gb|AAIH02000271.1|:c11456-9880 < Aspergillus flavus NRRL3357

gcontig_1106287685065

$>$ A.flavus_hxnX $=\underline{1,576 \mathrm{nt}}$

$<272$ nt $>$

$>$ gb|AAIH02000271.1|:11728-12678 > Aspergillus flavus NRRL3357

gcontig_1106287685065

$>$ A.flavus_hxnW $=\underline{950 \mathrm{nt}}$

$>143 \mathrm{nt}>$

>gb|AAIH02000271.1|:12821-14856 > Aspergillus flavus NRRL3357

gcontig_1106287685065 
$>$ A.flavus_hxnV $=\underline{2,035 \mathrm{nt}}$

$\langle\underline{778}$ nt $>$

$>$ gb|AAIH02000271.1|:15634-16894 > Aspergillus flavus NRRL3357

gcontig_1106287685065

$>$ A.flavus_hxnT $=\underline{1,260 \mathrm{nt}}$

$>42 \mathrm{nt}<$

$>$ gb|AAIH02000271.1|:c19461-16936 < Aspergillus flavus NRRL3357

gcontig_1106287685065

$>$ A.flavus_hxnR $=\underline{2,525 \mathrm{nt}}$

$<349$ nt $<$

$>$ gb|AAIH02000271.1|:c21551-19810 < Aspergillus flavus NRRL3357

gcontig_1106287685065

$>$ A.flavus_hxnP $=\underline{1,741 \mathrm{nt}}$

$<504$ nt $>$

$>$ gb|AAIH02000271.1|:22055-23205 > Aspergillus flavus NRRL3357

gcontig_1106287685065

$>$ A.flavus_hxnY $=\underline{1,150 \mathrm{nt}}$

$>423 \mathrm{nt}>$

>gb|AAIH02000271.1|:23628-25549 > Aspergillus flavus NRRL3357

gcontig_1106287685065

$>$ A.flavus_hxnZ $=\underline{1,921 \mathrm{nt}}$

$>2,500 \mathrm{nt}>$

>gb|AAIH02000271.1|:28049-29056 > Aspergillus flavus NRRL3357

gcontig_1106287685065 C-N-hydrolase

$>$ A.flavus_hxnM $=\underline{1,007 \mathrm{nt}}$

\section{Unlinked:}

>gb|AAIH02000147.1|:10471-11606 Aspergillus flavus NRRL3357

gcontig_1106287684703

$>$ A.flavus_hxnY-2 $=\underline{1,135 \mathrm{nt}}$

$>$ gb|AAIH02000012.1|:c13825-11943 Aspergillus flavus NRRL3357

gcontig_1106287686051

$>$ A.flavus_amidase $=\underline{1,182 \mathrm{nt}}$

hxn cluster Aspergillus kawachii (= A. niger): $\operatorname{size~25,074}$

nt

>gi|357297942:c70311-68141 < Aspergillus kawachii IFO 4308 contig00152

$>$ A.kawachii_hxnV $=\underline{2,170 ~ n t}$

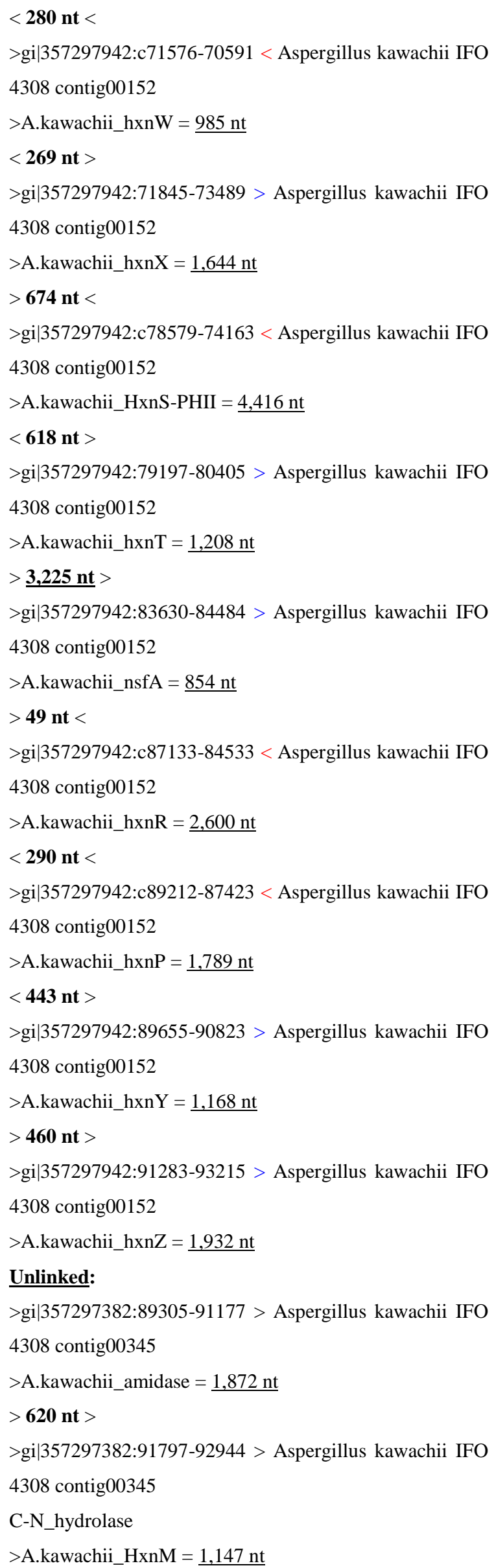




\section{hxn cluster Aspergillus nidulans: size 61,028 nt}

$>$ gb|AACD01000169.1|:c330031-327832 < Aspergillus

nidulans FGSC A4

chromosome IV ANcontig1.169

gi|259485327 ACCESSION BN001306 REGION:

$243,215 . .245,414$

$>$ A.nidulans_hxnV $=\underline{2,199 \mathrm{nt}}$

$<402 \mathrm{nt}<$

$>$ gb|AACD01000169.1|:c331293-330433 < Aspergillus

nidulans FGSC A4

chromosome IV ANcontig1.169

$>$ A.nidulans_hxnW $=\underline{860 \mathrm{nt}}$

$<189$ nt $>$

$>$ gb|AACD01000169.1|:331482-333063 > Aspergillus nidulans FGSC A4

chromosome IV ANcontig1.169

gi|259485327 ACCESSION BN001306 REGION:

$240,183 . .241,764$

$>$ A.nidulans_hxnX $=\underline{1,581 \mathrm{nt}}$

$>\underline{\mathbf{4 0 , 8 7 8} \mathbf{n t}}<(15$ transcripts predicted $)$

$>$ gb|AACD01000170.1|:c19017-17199 < Aspergillus

nidulans FGSC A4

chromosome IV ANcontig1.170

gi|259485327 ACCESSION BN001306 REGION:

$197,487 . .199,305$

$>$ A.nidulans_hxnZ $=\underline{1,818 \mathrm{nt}}$

$<332$ nt $<$

$>$ gb|AACD01000170.1|:c20565-19349 < Aspergillus

nidulans FGSC A4

chromosome IV ANcontig1.170

$>$ A.nidulans_hxnY $=\underline{1,216 \mathrm{nt}}$

$<587$ nt $>$

$>$ gb|AACD01000170.1|:21152-23003 > Aspergillus

nidulans FGSC A4

chromosome IV ANcontig1.170

$>$ A.nidulans_hxnP $=\underline{1,851 \mathrm{nt}}$

$>300 \mathrm{nt}>$

$>$ gb|AACD01000170.1|:23303-25963 > Aspergillus

nidulans FGSC A4

chromosome IV ANcontig1.170

gi|259485327 ACCESSION BN001306 REGION:

$190,541 . .193,213$

$>$ A.nidulans_hxnR $=\underline{2,660 \mathrm{nt}}$

$>68 \mathrm{nt}<$
$>$ gb|AACD01000170.1|:c27332-26031 < Aspergillus nidulans FGSC A4

chromosome IV ANcontig1.170

$>$ A.nidulans_hxnT $=\underline{1,301 \mathrm{nt}}$

$<428 \mathrm{nt}>$

gb|AACD01000170.1|:27760-32118 > Aspergillus

nidulans FGSC A4

chromosome IV ANcontig1.170

gi|259485327 ACCESSION BN001306 REGION:

$184,386 . .188,744$

$>$ A.nidulans_hxnS-PHII $=\underline{4,358 \mathrm{nt}}$

Unlinked:

>gb|AACD01000109.1|:c85737-84643 < Aspergillus nidulans FGSC A4

chromosome I ANcontig1.109 C-N_hydrolase "ㅅN6518"

$>$ A.nidulans_HxnM $=\underline{1,094 \mathrm{nt}}$

$<609$ nt $<$

$>$ gb|AACD01000109.1|:c88196-86346 < Aspergillus

nidulans FGSC A4

chromosome I ANcontig1.109

$>$ A.nidulans_amidase $=\underline{1,850 \mathrm{nt}}$

hxn cluster Aspergillus oryzae

>gi|83771634:c93389-91506 Aspergillus oryzae RIB40 DNA, SC111

>A.oryzae_amidase

>gi|83771634:c2317607-2316031 Aspergillus oryzae

RIB40 DNA, SC111

$>$ A.oryzae_hxnX

$>$ gi|83771634:2317878-2318828 Aspergillus oryzae

RIB40 DNA, SC111

$>$ A.oryzae_hxnW

>gi|83771634:2318973-2321009 Aspergillus oryzae

RIB40 DNA, SC111

$>$ A.oryzae_hxnV

>gi|83771634:2321787-2323047 Aspergillus oryzae

RIB40 DNA, SC111

$>$ A.oryzae_hxnT

>gi|83771634:c2325614-2323089 Aspergillus oryzae

RIB40 DNA, SC111

$>$ A.oryzae_hxnR

>gi|83771634:c2327703-2325962 Aspergillus oryzae

RIB40 DNA, SC111

>A.oryzae_hxnP 


$\begin{array}{llr}\text { >gi|83771634:2328211-2329360 } & \text { Aspergillus } & \text { oryzae } \\ \text { RIB40 DNA, SC111 } & & \\ \text { >A.oryzae_hxnY } & & \\ \text { >gi|83771634:2329788-2331709 } & \text { Aspergillus } & \text { oryzae } \\ \text { RIB40 DNA, SC111 } & & \\ \text { >A.oryzae_hxnZ } & & \\ \text { >gi|83771634:2334207-2335214 } & \text { Aspergillus } & \text { oryzae } \\ \text { RIB40 DNA, SC111 } & & \\ \text { >A.oryzae_hxnM } & & \end{array}$

\section{Unlinked:}

>gi|83766426:c452788-451431 Aspergillus oryzae RIB40 DNA, SC001

$>$ A.oryzae_hxnTlike

>gi|83775368:c576233-575098 Aspergillus oryzae RIB40 DNA, SC103

>A.oryzae_hxnY-2

\section{hxn Cluster Aspergillus sojae}

>gi|336284332:c5431-4376 Aspergillus sojae NBRC 4239 contig00151

$>$ A.sojae_HxnM

$>$ gi|336284332:c9873-7950 Aspergillus sojae NBRC 4239 contig00151

>A.sojae_hxnZ

$>$ gi|336284332:11958-13706 Aspergillus sojae NBRC 4239 contig00151

>A.sojae_hxnP

$>$ gi|336284332:14054-16582 Aspergillus sojae NBRC 4239 contig00151

>A.sojae_hxnR

$>$ gi|336284332:c17886-16624 Aspergillus sojae NBRC 4239 contig00151

>A.sojae_hxnT

$>$ gi|336284332:c20715-18679 Aspergillus sojae NBRC 4239 contig00151

$>$ A.sojae_hxnV

>gi|336284332:c21809-20864 Aspergillus sojae NBRC 4239 contig00151

$>$ A.sojae_hxnW

$>$ gi|336284332:22081-23656 Aspergillus sojae NBRC 4239 contig00151

$>$ A.sojae_hxnX

\section{Unlinked:}

>gi|336283823:c27947-26064 Aspergillus sojae NBRC 4239 contig00680
$>$ A.sojae_amidase

>gi|336284403:3480-5395 Aspergillus sojae NBRC 4239 contig00080

$>$ A.sojae_amidase-2

>gi|336284439:27842-28977 Aspergillus sojae NBRC 4239 contig00044

$>$ A.sojae_hxnY-2

$>$ gi|336284181:69531-70912 Aspergillus sojae NBRC 4239 contig00303

>A.sojae_hxnTlike

\section{hxn cluster Aspergillus terreus: size 20,116 nt}

>gb|AAJN01000215.1|:c46727-45088 < Aspergillus terreus NIH2624 cont 1.215

$>$ A.terreus_hxnX $=\underline{1,639 \mathrm{nt}}$

$<273 \mathrm{nt}>$

$>$ gb|AAJN01000215.1|:47000-47954 > Aspergillus terreus NIH2624 cont1.215

$>$ A.terreus_hxnW $=\underline{945 \mathrm{nt}}$

$>226 \mathrm{nt}>$

>gb|AAJN01000215.1|:48180-50133 > Aspergillus terreus $\mathrm{NIH} 2624$ cont 1.215

$>$ A.terreus_hxnV $=\underline{1,953 \mathrm{nt}}$

$>71 \mathrm{nt}<$

$>$ gb|AAJN01000215.1|:c54600-50204 < Aspergillus terreus NIH2624 cont1.215

$>$ A.terreus_hxnS-PHII $=\underline{4,396 \mathrm{nt}}$

$<500 \mathrm{nt}>$

$>$ gb|AAJN01000215.1|:55100-56400 > Aspergillus terreus $\mathrm{NIH} 2624$ cont 1.215

$>$ A.terreus_hxnT $=\underline{1,300 \mathrm{nt}}$

$>117 \mathrm{nt}<$

$>$ gb|AAJN01000215.1|:c59094-56517 < Aspergillus terreus NIH2624 cont 1.215

$>$ A.terreus_hxnR $=\underline{2,577 \mathrm{nt}}$

$<296 \mathrm{nt}<$

$>$ gb|AAJN01000215.1|:c61169-59390 < Aspergillus terreus NIH2624 cont1.215

$>$ A.terreus_hxnP $=\underline{1,779 \mathrm{nt}}$

$<566 \mathrm{nt}>$

$>$ gb|AAJN01000215.1|:61735-62867 > Aspergillus terreus NIH2624 cont1.215

$>$ A.terreus_hxnY $=\underline{1,132 \mathrm{nt}}$

$>456 \mathrm{nt}$ > 
>gb|AAJN01000215.1|:63323-65204 > Aspergillus terreus NIH2624 cont1.215

$>$ A.terreus_hxnZ $=\underline{1,881 \mathrm{nt}}$

\section{Unlinked:}

>gb|AAJN01000156.1|:c64554-63488 < Aspergillus terreus NIH2624 cont1.156

C-N_hydrolase

$>$ A.terreus_HxnM $=\underline{1,066 n t}$

> 485 nt >

$>$ gb|AAJN01000156.1|:c66899-65039 Aspergillus terreus $\mathrm{NIH} 2624$ cont1.156

$>$ A.terreus_amidase $=\underline{1,860 \mathrm{nt}}$

hxn cluster Glomerella graminicola (Glomerellales) : size $40,725 \mathrm{nt}$

$>$ gb|ACOD01000324.1|:c55773-52579 < Glomerella

graminicola M1.001 cont1.324

$>$ G.graminicola_hxnR $=\underline{3,194 \mathrm{nt}}$

$<907$ nt $>$

$>$ gb|ACOD01000324.1|:56680-58175 > Glomerella

graminicola M1.001 cont1.324

$>$ G.graminicola_hxnX $=\underline{1,495 \mathrm{nt}}$

$>412 \mathrm{nt}<$

$>$ gb|ACOD01000324.1|:c59997-58587 < Glomerella

graminicola M1.001 cont1.324

$>$ G.graminicola_hxnT $=\underline{1,410 \mathrm{nt}}$

$<2,056$ nt $<$

$>$ gb|ACOD01000324.1|:c63897-62053 < Glomerella

graminicola M1.001 cont1.324

$>$ G.graminicola_hxnZ $=\underline{1,844 \mathrm{nt}}$

$<965$ nt $<$

$>$ gb|ACOD01000324.1|:c66985-64862 < Glomerella

graminicola M1.001 cont1.324

$>$ G.graminicola_hxnV $=\underline{2,123 \mathrm{nt}}$

< $735 \mathrm{nt}>$

$>$ gb|ACOD01000324.1|:67720-69767 > Glomerella

graminicola M1.001 cont1.324

$>$ G.graminicola_amidase $=\underline{2,048 \mathrm{nt}}$

$>\underline{14,213 \mathrm{nt}}<$

$>$ gb|ACOD01000324.1|:c85251-83980 < Glomerella

graminicola M1.001 cont1.324

$>$ G.graminicola_C-N_hydrolase $=\mathrm{hxnM}=\underline{1,271 \mathrm{nt}}$

$\langle 1,194$ nt $>$

$>$ gb|ACOD01000324.1|:86445-87334 > Glomerella

graminicola M1.001 cont1.324
$>$ G.graminicola_hxnW $=\underline{889 \mathrm{nt}}$

$>2,467 \mathrm{nt}<$

$>$ gb|ACOD01000324.1|:c91571-89801 < Glomerella graminicola M1.001 cont1.324

$>$ G.graminicola_hxnP $=\underline{1,770 \mathrm{nt}}$

$<530$ nt $<$

$>$ gb|ACOD01000324.1|:c93304-92101 < Glomerella

graminicola M1.001 cont 1.324

$>$ G.graminicola_hxnY $=\underline{1,203 \mathrm{nt}}$

Unlinked:

>gb|ACOD01000027.1|:443727-445919 Glomerella

graminicola M1.001 cont $\underline{\mathbf{1 . 2 7}}$

(paralog omnipresent in Sordariomycetes)

>G.graminicola_hxnV-2 $=\underline{2,192 \mathrm{nt}}$

hxn cluster Gibberella moniliformis (Fusarium verticillioides): size $25,506 \mathrm{nt}$

>gb|AAIM02000142.1|:105832-106986 > Gibberella moniliformis 7600 chromosome 9

cont3.142

$>$ G.moniliformis_hxnY $=\underline{1,154 \mathrm{nt}}$

$>961 \mathrm{nt}>$

>gb|AAIM02000142.1|:107947-109619 > Gibberella moniliformis 7600 chromosome 9

cont 3.142

$>$ G.moniliformis_hxnP $=\underline{1,672 \mathrm{nt}}$

$>1,216 \mathrm{nt}<$

$>$ gb|AAIM02000142.1|:c111712-110835 < Gibberella moniliformis 7600 chromosome 9

cont 3.142

$>$ G.moniliformis_hxnW $=\underline{877 \mathrm{nt}}$

< 519 nt >

$>$ gb|AAIM02000142.1|:112231-113496 > Gibberella moniliformis 7600 chromosome 9

cont 3.142

$>$ G.moniliformis_C-N_hydrolase $=\mathrm{hxnM}=\underline{1,265 \mathrm{nt}}$

$>$ 2,961 nt >

$>$ gb|AAIM02000142.1|:c118418-116457 < Gibberella

moniliformis 7600 chromosome 9

cont3.142

$>$ G.moniliformis_amidase $=\underline{1,961 \mathrm{nt}}$

$<496 \mathrm{nt}>$

$>$ gb|AAIM02000142.1|:118914-120904 > Gibberella

moniliformis 7600 chromosome 9

cont3.142 
$>$ G.moniliformis_hxnV $=\underline{1,990 \mathrm{nt}}$

$>817 \mathrm{nt}>$

$>$ gb|AAIM02000142.1|:121721-123538 > Gibberella

moniliformis 7600 chromosome 9

cont3.142

$>$ G.moniliformis_hxnZ $=\underline{1,817 \mathrm{nt}}$

$>825 \mathrm{nt}>$

$>$ gb|AAIM02000142.1|:124363-125777 > Gibberella

moniliformis 7600 chromosome 9

cont 3.142

$>$ G.moniliformis_hxnT $=\underline{1,414 \mathrm{nt}}$

$>531 \mathrm{nt}<$

$>$ gb|AAIM02000142.1|:c127773-126308 < Gibberella

moniliformis 7600 chromosome 9

cont3.142

$>$ G.moniliformis_hxnX $=\underline{1,465 \mathrm{nt}}$

$<541 \mathrm{nt}>$

$>$ gb|AAIM02000142.1|:128314-131338 > Gibberella

moniliformis 7600 chromosome 9

cont 3.142

$>$ G.moniliformis_hxnR $=\underline{3,024 \mathrm{nt}}$

Unlinked:

>gb|AAIM02000013.1|:51184-53330 > Gibberella

moniliformis 7600 chromosome 1

cont3.13 (paralog onmipresent in Sordariomycetes)

$>$ G.moniliformis_hxnV-2 = 2,146 nt

$>$ gb|AAIM02000166.1|:c282445-278039 < Gibberella

moniliformis 7600 chromosome 3

cont3.166 (note: partial on edge of contig)

$>$ G.moniliformis_hxnS-PHIIPart $=\geq 4,406 \mathrm{nt}$

$>$ gb|AAIM02000047.1|:c211441-208608 < Gibberella

moniliformis 7600 chromosome 5

cont3.47 (seems a relic in phylogenetic analysis)

$>$ G.moniliformis_hxnR-2 $=\underline{2,833 \mathrm{nt}}$

hxn cluster Grosmannia clavigera (Ophiostomatales):

\section{size 44,348 nt}

>gb|ACXQ02000048.1|:376723-380065 > Grosmannia clavigera kw1407 contig_132.1

$>$ G.clavigera_hxnR $=\underline{3,342 \mathrm{nt}}$

$>632 \mathrm{nt}<$

$>$ gb|ACXQ02000048.1|:c376091-374972 < Grosmannia

clavigera kw1407 contig_132.1

$>$ G.clavigera_C-N_hydrolase $=$ hxnM $=\underline{1,119 \mathrm{nt}}$

$<\underline{22,687 \text { nt }}>$
>gb|ACXQ02000048.1|:350432-352285 > Grosmannia clavigera kw1407 contig_132.1

$>$ G.clavigera_amidase $=\underline{1,853 \mathrm{nt}}$

$>555$ nt $<$

$>$ gb|ACXQ02000048.1|:c349877-347890 < Grosmannia clavigera kw1407 contig_132.1

$>$ G.clavigera_hxnV $=\underline{1,987 \mathrm{nt}}$

$<559$ nt $<$

$>$ gb|ACXQ02000048.1|:c347331-345653 < Grosmannia clavigera kw1407 contig_132.1

$>$ G.clavigera_hxnZ $=\underline{1,678 \mathrm{nt}}$

$<647$ nt $<$

>gb|ACXQ02000048.1|:c345006-343744 < Grosmannia clavigera kw1407 contig_132.1

$>$ G.clavigera_hxnT $=\underline{1,262 \mathrm{nt}}$

$<2,163$ nt $>$

$>$ gb|ACXQ02000048.1|:340114-341581 > Grosmannia

clavigera kw1407 contig_132.1

$>$ G.clavigera_hxnX $=\underline{1,467 \mathrm{nt}}$

$<374$ nt $>$

>gb|ACXQ02000048.1|:c339740-338885 < Grosmannia clavigera kw1407 contig_132.1

$>$ G.clavigera_hxnW $=\underline{855 \mathrm{nt}}$

$>233$ nt $<$

$>$ gb|ACXQ02000048.1|:336964-338652 > Grosmannia clavigera kw1407 contig_132.1

$>$ G.clavigera_hxnP $=\underline{1,688 \mathrm{nt}}$

$<243$ nt $<$

$>\mathrm{gb}|\mathrm{ACXQ} 02000048.1|: 335717-336721>$ Grosmannia clavigera kw1407 contig_132.1

$>$ G.clavigera_hxnY $=\underline{1,004 \mathrm{nt}}$

Unlinked:

>gb|ACXQ02000048.1|:49692-50546 Grosmannia

clavigera kw1407 contig_132.1

$>$ G.clavigera_nfsA $=\underline{855 \mathrm{nt}}$

>gb|ACXQ02000097.1|:35988-38127 Grosmannia

clavigera kw1407 contig_161.1

(paralog omnipresent in Sordariomycetes)

$>$ G.clavigera_hxnV-2 $=\underline{2,139 n t}$

hxn cluster Sclerotinia sclerotiorum: size 10,577 nt

>gb|AAGT01000385.1|:c12900-8393 < Sclerotinia

sclerotiorum $1980 \mathrm{UF}-70$

strain 1980 cont 1.385

$>$ S.sclerotiorum_hxnS-PHII $=\underline{4,507 \mathrm{nt}}$ 
$<1,303$ nt $<$

$>$ gb|AAGT01000385.1|:c16408-14203 < Sclerotinia

sclerotiorum 1980 UF-70

strain 1980 cont 1.385

$>$ S.sclerotiorum_hxnV $=\underline{2,205 \mathrm{nt}}$

$<509$ nt $>$

$>$ gb|AAGT01000385.1|:16917-18970 > Sclerotinia

sclerotiorum 1980 UF-70

strain 1980 cont 1.385

$>$ S.sclerotiorum_hxnX $=\underline{2,053 \mathrm{nt}}$

Unlinked

>gb|AAID01003621.1|:c16612-15383

fuckeliana B05.10 cont 1.3621

$>$ B.cinerea_C-N_hydrolase $=$ hxnM

>gb|AAGT01000038.1|:26843-28077

sclerotiorum 1980 UF-70

strain 1980 cont 1.38

>S.sclerotiorum_C-N_hydrolase $=$ hxnM

\section{JGI Hysterium pulicare hxn clusters}

>NODE_1220_length_910039_cov_26.360939|1797|3589

(1793 bp) AP

$>$ H.pulicare_hxnP

$<720$ nt $<$

$>$ NODE_1220_length_910039_cov_26.360939|4309|6455

(2147 bp) AP

$>$ H.pulicare_hxnV

$<490 \mathrm{nt}>$

>NODE_1220_length_910039_cov_26.360939|6945|8874 (1930 bp)

$>$ H.pulicare_amidase

$>609$ nt >

$>$ NODE_1220_length_910039_cov_26.360939|9483|1057

8 (1096 bp)

$>$ H.pulicare_hxnM

$>430 \mathrm{nt}>$

>NODE_1220_length_910039_cov_26.360939|11008|125

51 (1544 bp)

$>$ H.pulicare_hxnX

>NODE_322_length_79727_cov_25.799076|43222|44559

(1338 bp)

$>$ H.pulicare_hxnY

$>\underline{12,157 \mathrm{nt}}<$

$>$ NODE_322_length_79727_cov_25.799076|56716|60006

(3291 bp) AP
$>$ H.pulicare_HxnR

$<685 \mathrm{nt}<$

$>$ NODE_322_length_79727_cov_25.799076|60691|65200

(4509 bp) AP

$>$ H.pulicare_hxnS-PHII

$<1,010 \mathrm{nt}>$

$>$ NODE_322_length_79727_cov_25.799076|66210|67623

(1414 bp)

$>$ H.pulicare_hxnT

hxn clusters Mycosphaerella fijiensis (JGI genome)

hxn Cluster 1: size 9,766 nt

$>$ Mycosphaerella fijiensis > scaffold_5|802739|804266

(1528 bp)

$>$ M.fijiensis_hxnX $=\underline{1,527 \mathrm{nt}}$

$>210 \mathrm{nt}<$

$>$ Mycosphaerella fijiensis < scaffold_5|804476|806425 (1950 bp) AP

$>$ M.fijiensis_hxnV $=\underline{1,949 \mathrm{nt}}$

$<398$ nt $>$

$>$ Mycosphaerella fijiensis > scaffold_5|806823|807820 (998 bp)

$>$ M.fijiensis_hxnM $=\underline{997 \mathrm{nt}}$

$>372 \mathrm{nt}>$

>Mycosphaerella fijiensis >scaffold_5|808192|809412 (1221 bp)

$>$ M.fijiensis_hxnT $=\underline{1,220 \mathrm{nt}}$

$>467 \mathrm{nt}>$

$>$ Mycosphaerella fijiensis > scaffold_5|809879|812505 (2627 bp)

$>$ M.fijiensis_hxnR $=\underline{2,626 n t}$

hxn Cluster 2: size 6,057 nt (unlinked to Cluster 1)

$>$ Mycosphaerella fijiensis < scaffold_2|4950804|4952022 (1219 bp) AP

$>$ M.fijiensis_hxnY $=\underline{1,218 \mathrm{nt}}$

$<417 \mathrm{nt}<$

$>$ Mycosphaerella fijiensis < scaffold_2|4952439|4956861 (4423 bp) AP

$>$ M.fijiensis_hxnS-PHII $=\underline{4,422 \mathrm{nt}}$

hxn cluster Nectria haematococca (Fusarium solanif. sp. pisi): size 21,236 nt

$>$ gb|ACJF01000056.1|:c115648-112600 < Nectria

haematococca mpVI 77-13-4

chromosome 12 NECHAsca_56_chr12_3_0_Cont56

$>$ N.haematococca_hxnR $=\underline{3,048 \mathrm{nt}}$ 


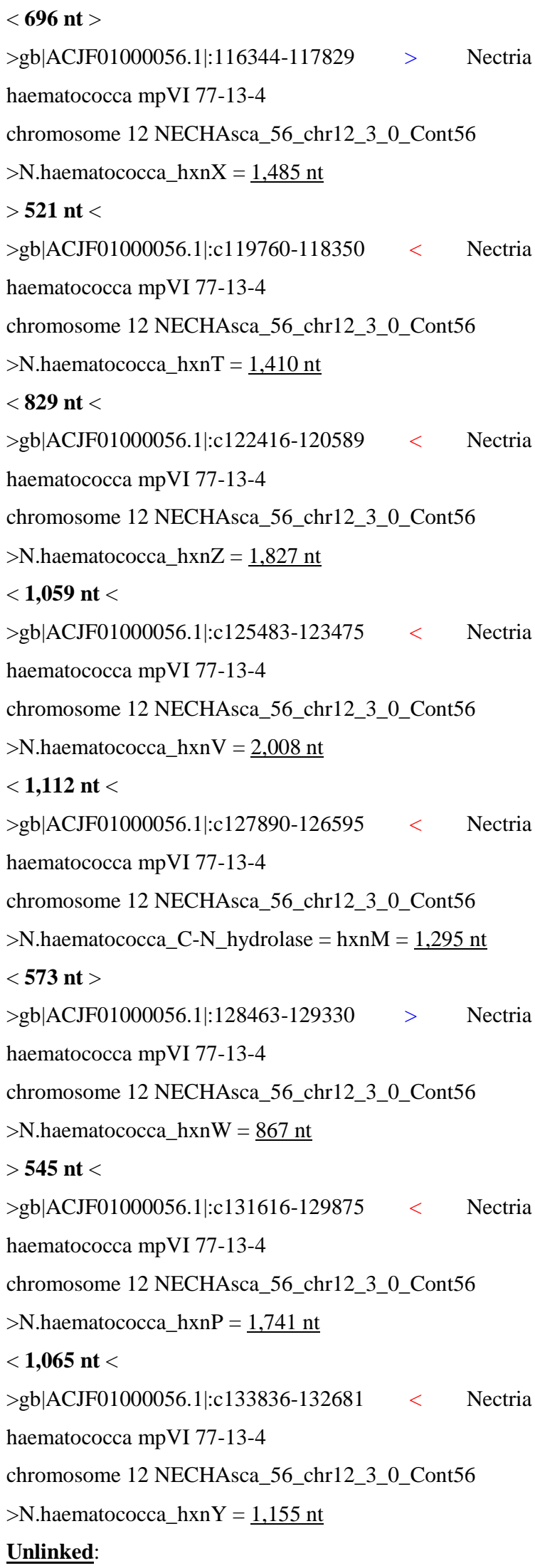

$>$ N.haematococca_hxnV-2 $=\underline{2,150 \mathrm{nt}}$

$>$ gb|ACJF01000017.1|:589089-593861

Nectria

haematococca mpVI 77-13-4

chromosome 4 NECHAsca_19_chr4_3_0_Cont17

$>$ N.haematococca_hxnS-PHII $=\underline{4,772 \mathrm{nt}}$

$>$ gb|ACJF01000029.1|:82980-84527

Nectria

haematococca mpVI 77-13-4

chromosome 11 NECHAsca_30_chr11_1_0_Cont29

(duplication hxnP)

$>$ N.haematococca_hxnP-2 $=\underline{1,547 \text { bp }}$

>gb|ACJF01000048.1|:138132-139914

Nectria haematococca mpVI 77-13-4

chromosome 16 NECHAsca_50_chr16_1_0_Cont48

(duplication hxnZ)

$>$ N.haematococca_hxnZ-2 $=\underline{1,782 \mathrm{nt}}$

hxn cluster Paracoccidioides brasiliensis strain Pb03: size $29,109 \mathrm{nt}$

>gb|ABHV01000435.1|:c108721-106610

Paracoccidioides brasiliensis $\mathrm{Pb} 03$ cont 1.435

$>$ P.brasiliensis_hxnX $=\underline{2,111 \mathrm{nt}}$

$<1,234$ nt $<$

$>$ gb|ABHV01000435.1|:c111187-109955

Paracoccidioides brasiliensis $\mathrm{Pb} 03$ cont 1.435

$>$ P.brasiliensis_C-N_hydrolase $=\mathrm{hxnM}=\underline{1,232 \mathrm{nt}}$

$<748 \mathrm{nt}>$

$>$ gb|ABHV01000435.1|:111935-113171

Paracoccidioides brasiliensis Pb03 cont 1.435

$>$ P.brasiliensis_hxnW $=\underline{1,236 \mathrm{nt}}$

$>277$ nt $<$

$>$ gb|ABHV01000435.1|:c115503-113448 Paracoccidioides brasiliensis $\mathrm{Pb} 03$ cont 1.435

$>$ P.brasiliensis_amidase $=\underline{2,055 \mathrm{nt}}$

$<843 \mathrm{nt}>$

$>$ gb|ABHV01000435.1|:116346-118588

Paracoccidioides brasiliensis $\mathrm{Pb} 03$ cont 1.435

$>$ P.brasiliensis_hxnV $=\underline{2,242 \mathrm{nt}}$

$>\mathbf{5 , 4 9 7} \mathrm{nt}<$

$>$ gb|ABHV01000435.1|:c128734-124085

Paracoccidioides brasiliensis $\mathrm{Pb} 03$ cont 1.435

$>$ P.brasiliensis_hxnS-PHII $=\underline{4,649 \mathrm{nt}}$

$<1,613 \mathrm{nt}>$

>gb|ABHV01000435.1|:130347-131828

Paracoccidioides brasiliensis $\mathrm{Pb} 03$ cont 1.435

$>$ P.brasiliensis_hxnT $=\underline{1,481 \mathrm{nt}}$ 
$>604$ nt $<$

$>$ gb|ABHV01000435.1|:c135719-132432

Paracoccidioides brasiliensis $\mathrm{Pb} 03$ cont 1.435

$>$ P.brasiliensis_hxnR $=\underline{3,287 \mathrm{nt}}$

\section{hxn cluster Phaeosphaeria nodorum: size 26,464 nt}

(similar in Leptosphaeria maculans)

$>$ gb|AAGI01000083.1|:c80177-78587 < Phaeosphaeria nodorum SN15 cont1.83

$>$ P.nodorum_hxnP $=\underline{1,590 \mathrm{nt}}$

$<546 \mathrm{nt}<$

$>$ gb|AAGI01000083.1|:c82711-80723 < Phaeosphaeria nodorum SN15 cont 1.83

$>$ P.nodorum_hxnV $=\underline{1,988 \mathrm{nt}}$

$<586 \mathrm{nt}$ >

$>$ gb|AAGI01000083.1|:83297-85333 > Phaeosphaeria nodorum SN15 cont 1.83

$>$ P.nodorum_amidase $=\underline{2,037} \mathrm{nt}$

$>362 \mathrm{nt}>$

>gb|AAGI01000083.1|:85695-86878 Phaeosphaeria

nodorum SN15 cont 1.83

$>$ P.nodorum_C-N_hydrolase $=$ hxnM $=\underline{1,183 \mathrm{nt}}$

$>697 \mathrm{nt}>$

$>$ gb|AAGI01000083.1|:87575-89121 > Phaeosphaeria nodorum SN15 cont 1.83

$>$ P.nodorum_hxnX $=\underline{1,546 \mathrm{nt}}$

$>\underline{\mathbf{5 . 2 7 3} \mathrm{nt}}<$

$>$ gb|AAGI01000083.1|:c95736-94394 < Phaeosphaeria nodorum SN15 cont 1.83

$>$ P.nodorum_hxnT $=\underline{1,342 \mathrm{nt}}$

$<521 \mathrm{nt}>$

$>$ gb|AAGI01000083.1|:96257-100778 > Phaeosphaeria nodorum SN15 cont 1.83

$>$ P.nodorum_hxnS-PHII $=\underline{4,521 \mathrm{nt}}$

$>957$ nt $>$

>gb|AAGI01000083.1|:101735-105051 > Phaeosphaeria nodorum SN15 cont1.83

$>$ P.nodorum_hxnR $=\underline{3,316 \mathrm{nt}}$

Unlinked:

>gb|AAGI01000408.1|:18330-19495

nodorum SN15 cont1.408

$>$ P.nodorum_hxnY $=\underline{1,165 \mathrm{nt}}$

\section{hxn cluster Pyrenophora tritici-repentis: size 26,464 nt}

(similar in P. teres f. sp. teres, Alternaria brassicicola, Cochliobolus heterostrophus (C5), C. sativus, and Setosphaeria turcica)

$>$ gb|AAXI01000364.1|:c6301-4979 < Pyrenophora triticirepentis Pt-1C-BFP

cont 1.364

$>$ P.tritici-repentis_hxnT $=\underline{1,322 \mathrm{nt}}$

$<542 \mathrm{nt}>$

>gb|AAXI01000364.1|:6843-11423 > Pyrenophora triticirepentis Pt-1C-BFP

cont 1.364

$>$ P.tritici-repentis_hxnS-PHII $=\underline{4,580 \mathrm{nt}}$

$>882$ nt $>$

$>$ gb|AAXI01000364.1|:12305-15633 > Pyrenophora triticirepentis Pt-1C-BFP

cont 1.364

$>$ P.tritici-repentis_hxnR $=\underline{3,328 \mathrm{nt}}$

$>\underline{8,001} \mathrm{nt}<$

$>$ gb|AAXI01000364.1|:c25623-23634 < Pyrenophora tritici-repentis Pt-1C-BFP

cont 1.364

$>$ P.tritici-repentis_hxnV $=\underline{1,989 \mathrm{nt}}$

$<603 \mathrm{nt}>$

$>$ gb|AAXI01000364.1|:26226-28180 > Pyrenophora triticirepentis Pt-1C-BFP

cont 1.364

$>$ P.tritici-repentis_amidase $=\underline{1,955 \mathrm{nt}}$

$>428 \mathrm{nt}>$

$>$ gb|AAXI01000364.1|:28608-29803 > Pyrenophora triticirepentis Pt-1C-BFP

cont 1.364

$>$ P.tritici-repentis_C-N_hydrolase $=\mathrm{hxnM}=\underline{1,195 \mathrm{nt}}$

$>576 \mathrm{nt}>$

>gb|AAXI01000364.1|:30379-31864 > Pyrenophora triticirepentis Pt-1C-BFP

cont1.364

$>$ P.tritici-repentis_hxnX $=\underline{1,485 \mathrm{nt}}$

\section{Unlinked:}

>gb|AAXI01000374.1|:46051-47226 Pyrenophora triticirepentis Pt-1C-BFP

cont1.374 hyoscyamine 6-dioxygenase

$>$ P.tritici-repentis_hxnY $=\underline{1,175 \mathrm{nt}}$ 


\section{hxn cluster Talaromyces stipitatus: size $18,505 \mathrm{nt}$}

$>$ gb|ABAS01000027.1|:c141724-140140 < Talaromyces stipitatus ATCC 10500

gcontig_1105507295319

$>$ T.stipitatus_hxnX $=\underline{1,584 \mathrm{nt}}$

$<242$ nt $>$

$>$ gb|ABAS01000027.1|:141966-142935 > Talaromyces

stipitatus ATCC 10500

gcontig_1105507295319

$>$ T.stipitatus_hxnW $=\underline{969 \mathrm{nt}}$

$>164 \mathrm{nt}>$

$>$ gb|ABAS01000027.1|:143099-145121 > Talaromyces stipitatus ATCC 10500

gcontig_1105507295319

$>$ T.stipitatus_hxnV $=\underline{2,022 \mathrm{nt}}$

$<\underline{\mathbf{3 8 0} \text { nt }}>$

$>$ gb|ABAS01000027.1|:145501-146761 > Talaromyces stipitatus ATCC 10500 gcontig_1105507295319

$>$ T.stipitatus_hxnT $=\underline{1,260 \mathrm{nt}}$

$>42 \mathrm{nt}<$

$>$ gb|ABAS01000027.1|:c149321-146803 < Talaromyces stipitatus ATCC 10500 gcontig_1105507295319

$>$ T.stipitatus_hxnR $=\underline{2,518 \mathrm{nt}}$

$<401$ nt $<$

$>$ gb|ABAS01000027.1|:c151435-149722 < Talaromyces stipitatus ATCC 10500 gcontig_1105507295319

$>$ T.stipitatus_hxnP $=\underline{1,713 \mathrm{nt}}$

$<\mathbf{5 1 3} \mathbf{n t}>$

$>$ gb|ABAS01000027.1|:151948-153101 > Talaromyces stipitatus ATCC 10500 gcontig_1105507295319

$>$ T.stipitatus_hxnY $=\underline{1,153 \mathrm{nt}}$

$>410 \mathrm{nt}>$

$>$ gb|ABAS01000027.1|:153511-155432 > Talaromyces stipitatus ATCC 10500 gcontig_1105507295319

$>$ T.stipitatus_hxnZ $=\underline{1,921 \mathrm{nt}}$

$>2,156 \mathrm{nt}>$

$>$ gb|ABAS01000027.1|:157588-158645 > Talaromyces stipitatus ATCC 10500

gcontig_1105507295319

$>$ T.stipitatus_C-N_hydrolase $=\mathrm{hxnM}=\underline{1,057 \mathrm{nt}}$

$>$ 4,152 nt $<$

$>$ gb|ABAS01000027.1|:c164802-162797 Talaromyces

stipitatus ATCC 10500

gcontig_1105507295319

$>$ T.stipitatus_amidase $=\underline{2,005 \mathrm{nt}}$ hxn genes Tuber melanosporum (Pezizomycetes class) >gi|295506971:c139110-134465 < Tuber melanosporum, contig_281, strain Mel28

$>$ T.melanosporum_hxnS-PHII $=\underline{4,645 \mathrm{nt}}$

$<\underline{\mathbf{2 4 , 3 2 3 ~ n t}}<$ (sort of linked)

$>$ gi|295506971:c165432-163433 < Tuber melanosporum, contig_281, strain Mel28

$>$ T.melanosporum_hxnV $=\underline{1,999 \mathrm{nt}}$

$<\underline{1,913 \mathrm{nt}}>$

>gi|295506971:167345-169712 > Tuber melanosporum, contig_281, strain Mel28

$>$ T.melanosporum_amidase $=\underline{2,368 \mathrm{nt}}$

>gi|295506963:c35050-34134 < Tuber melanosporum, contig_289, strain Mel28

$>$ T.melanosporum_hxnW $=\underline{916 \mathrm{nt}}$

$>1,835 \mathrm{nt}>$

>gi|295506963:36885-38039 Tuber melanosporum, contig_289, strain Mel28

$>$ T.melanosporum_C-N_hydrolase $=\mathrm{hxnM}=\underline{1,154 \mathrm{nt}}$

$>1,365 \mathrm{nt}>$

>gi|295506963:39404-40979 > Tuber melanosporum, contig_289, strain Mel28

$>$ T.melanosporum_hxnX $=\underline{1,575 \mathrm{nt}}$

$>$ gi|295506708:c28786-25662 < Tuber melanosporum, contig_546, strain Mel28

$>$ T.melanosporum_hxnS-2-PHIIPseudo $=\underline{1,124 \mathrm{nt}}$

$>$ gi|295503925:c37502-36163 < Tuber melanosporum, contig_1329, strain Mel28

$>$ T.melanosporum_hxnT $=\underline{1,339 \mathrm{nt}}$

$>$ gi|295503655:c75591-71270 < Tuber melanosporum, contig_1599, strain Mel28

>T.melanosporum_hxA-PHI $=4,321 \mathrm{nt}$

\section{hxn cluster Botryosphaeria dothidea}

anamorph: Dothiorella berengeriana or Fusicoccum aesculi

Dothideomycetes; Dothideomycetes incertae sedis; Botryosphaeriales; Botryosphaeriaceae; Botryosphaeria

>NODE_1365_length_49077_cov_59.050289|12060|1462

3 (2564 bp) AP

$>$ B.dothidea_amidase

$<741 \mathrm{nt}>$

$>$ NODE_1365_length_49077_cov_59.050289|15364|1763

0 (2267 bp)

>B.dothidea_hxnV 


\section{$>\underline{\mathbf{4 , 4 7 0} \mathrm{nt}}<$}

>NODE_1365_length_49077_cov_59.050289|22100|2360

7 (1508 bp) AP

$>$ B.dothidea_hxnX

$<605 \mathrm{nt}<$

$>$ NODE_1365_length_49077_cov_59.050289|24212|2534

4 (1133 bp) AP

$>$ B.dothidea_hxnM

$<946$ nt <

>NODE_1365_length_49077_cov_59.050289|26290|2760

2 (1313 bp) AP

$>$ B.dothidea_hxnT

$<605$ nt $>$

>NODE_1365_length_49077_cov_59.050289|28207|3280

3 (4597 bp)

$>$ B.dothidea_HxnS-PHII

$>2,197 \mathrm{nt}>$

>NODE_1365_length_49077_cov_59.050289|35000|3869

6 (3697 bp)

>B.dothidea_hxnR

$>2,009$ nt $<$

$>$ NODE_1365_length_49077_cov_59.050289|40795|4224

0 (1446 bp) AP

$>$ B.dothidea_hxnY

< 692 nt >

>NODE_1365_length_49077_cov_59.050289|42932|4476

9 (1838 bp)

>B.dothidea_hxnZ

\section{Unlinked}

>NODE_8152_length_150613_cov_65.218796|92352|942

72 (1921 bp)

$>$ B.dothidea_hxnP

>NODE_3726_length_70215_cov_61.707100|17790|1861

7 (828 bp)

>B.dothidea_hxnWlike

\section{Remnant hxn cluster Neosartorya fischeri: size $9,283 \mathrm{nt}$}

>gb|AAKE03000012.1|:159786-164138 > Neosartorya fischeri NRRL 181

ctgupdate_1099437635460

$>$ N.fischeri_hxnS-PHII $=\underline{4,352 \mathrm{nt}}$

$>41 \mathrm{nt}<$

$>$ gb|AAKE03000012.1|:c166230-164179 < Neosartorya

fischeri NRRL 181

ctgupdate_1099437635460
$>$ N.fischeri_hxnV $=\underline{2,051 \mathrm{nt}}$

$<\underline{\mathbf{1 , 2 0 7} \mathrm{nt}}$ >

$>$ gb|AAKE03000012.1|:167437-169069 > Neosartorya fischeri NRRL 181

ctgupdate_1099437635460

$>$ N.fischeri_hxnX $=\underline{1,632 \mathrm{nt}}$

Unlinked:

>gb|AAKE03000023.1|:291704-292828 Neosartorya

fischeri NRRL 181

ctgupdate_1099437635428

$>$ N.fischeri_hxnY $=\underline{1,124 \mathrm{nt}}$

>gb|AAKE03000001.1|:1598703-1599742 Neosartorya

fischeri NRRL 181

ctgupdate_1099437635467 C-N_hydrolase

$>$ N.fischeri_hxnM-2

>gb|AAKE03000001.1|:c133414-132091 Neosartorya

fischeri NRRL 181

ctgupdate_1099437635467

$>$ N.fischeri_hxnTlike

>gb|AAKE03000040.1|:25777-27652 > Neosartorya

fischeri NRRL 181

ctgupdate_1099437635404

$>$ N.fischeri_amidase $=\underline{1,875 \mathrm{nt}}$

$>657 \mathrm{nt}>$

$>$ gb|AAKE03000040.1|:28309-29420 > Neosartorya

fischeri NRRL 181

ctgupdate_1099437635404 C-N_hydrolase

$>$ N.fischeri_hxnM $=\underline{1,111 \mathrm{nt}}$ 